$\underset{65}{A-J}\left[\begin{array}{c}\text { ohanzen, } \\ \text { G.E. }]\end{array}\right.$ 1907 


\section{HARVARD UNIVERSITY}

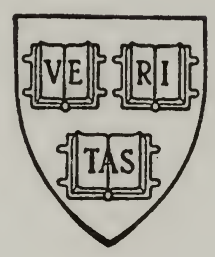

\section{LIBRARY}

OF THE

Museum of Comparative Zoology 





\section{Johanzen, G Dre. 31,1931
r. Э. оганзенъ,}

консерваторъ Зоологическаго Музея Императорскаго Томскаго Университета.
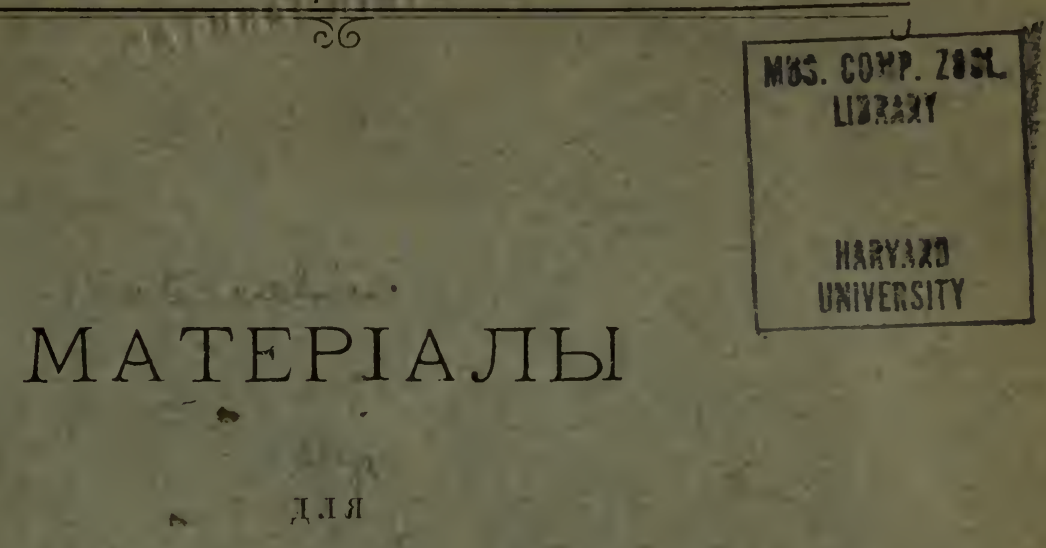

ОРНИТОФАУНЫ СТЕПЕЙ

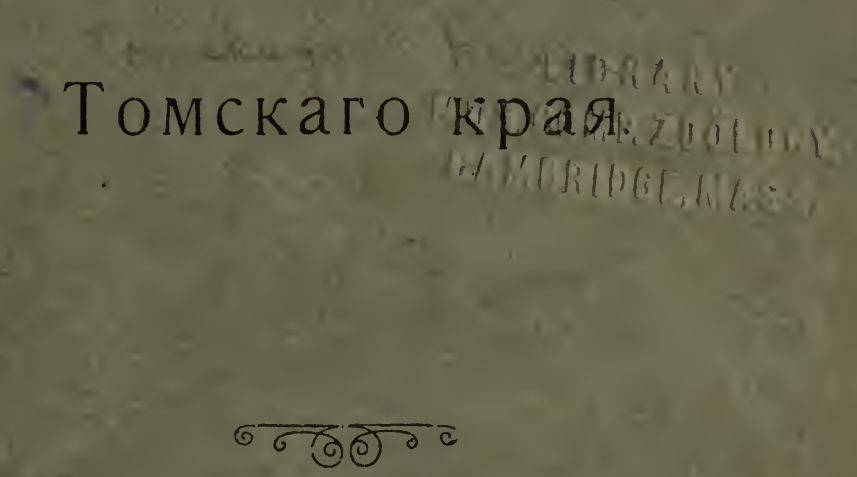

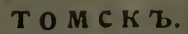

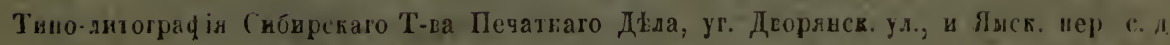
1907. 


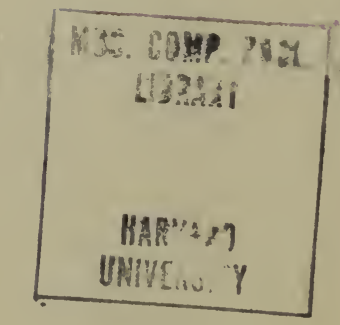


PEM ANDENKEN

\title{
SEINER MUTTER
}

\author{
der Verfasser.
}



Совъту Сибирскаго Университета, давшему мнґ возможность изучить пернатое населеніе степей Томскаго края, приношу глубокую благодарность.

Г. Гоганзенъ. 

Во время нъсколькихъ пођздокъ въ степную часть Тимскаго края, предпринятыхъ различными лицами по порученію Совъта Императорскаго Томскаго Университета, собрант значительный орнитологическій матеріалъ, обработкою котораго я занимался въ теченіе посльднихъ льтъ, посколько позволяло это мнь свободное оть исполненія въ Томскомъ Реальномъ Училищъ преподавательскихъ обязанностей время. Описаніе всего обработаннаго мною матеріала я прєдпочелъ соединить въ одну работу, такъ какъ въ совокупности онъ болье способенъ характеризовать орнитофауну степной части Томскаго края, чЂмъ если-бы появились отдъльныя описанія поъздокъ съ иписа̊ніями собраннаго во время ихъ матеріала.

Для пополненія и надлежащаго освъщенія матеріала, хранящагося въ нашихъ коллекціяхъ, я постарался внести и данныя орнитологической литературы, посколько она имъеть отношеніе къ нашимг, степямь и была мнб доступна. Исходя изъ того соображенія, чтп сдъланное для изученія данной мъстности предшественниками голжно быть вполнъ ясно выдълено оть работы автора, чтобы и незнающй всъхъ подробностей литературы дан. наго вонроса читатель могъ для каждой формы видъть, что сдђлано авторомъ и что уже раньше было извъстно, я всюду указывалъ на заслуги предшественниковъ моихъ въ области изученія орнитофауны нашихъ степей и не постьснился почти всюду въ спеціальной части моей работы указать точно и страницу сочиненія, гдъ данный видъ птицы упоминается. При оо́работкь матеріала Университетскихъ коллекцій я попутно пересмотрђлъ шкурки и яйца своей частной коллекціи, посколько онъ имьютъ отношеніе къ нашимъ степямъ. Этотъ матеріалъ (около 130 птицъ) мною также измьренъ и внесенъ въ спєціальную часть. Онъ мною пріэбрьтенъ отъ гг. Н. В. М арков а, А. П. Велижанина, П. А. Ш астовск аг о и др., коллектировавшихьвъ с. Тулинскомъ на Оби (Барнаульскаго убзда), въ окрестностяхъ г. Барнаула и ст. Каинскъ. 
Во время этихъ занятій я все время ощущалъ крайній недостатокъ въ матеріаль для сравненія, въ особенности изъ Западной Европы, отсутствуюшемъ въ нашемъ музеъ. Только относительно нћкоторыхъ формъ я могъ частью путемъ обмъна дублетовь своей частной коллекціи, частью путемъ покупки матеріала на свои собственныя средства устранить въ нбкоторой степени эти затрудненія. С. А. Бутурлинъ и von Tschusi оказали мнъ предоставленіемъ на время н'которыхъ экземпляровъ ихъ частныхъ обширныхъ гпллекцій нбкоторую помощь, за которую я имъ и здћсь позволю себъ выразить искреннюю благодарность.

Ообладать матеріаломъ для сравненія тьмм болье необходимо въ настоящее время при систематическихъ занятіяхъ, пто современная систематика не удовлетворяется опредъленіемъ вида, дъломъ неосибенно труднымъ, а требуетъ и опредћленіе подвида; задача эта весьма трудная, когда матеріала по данному виду изъ всей области его распространенія нбтъ подъ руками.

Пођздокъ, предпринятыхъ по порученію Совъта Университета, пять.

\section{I. Побздка 1891 г. въ Барабинскую степь.}

Льътомь 1891 г. проф. Н. Ө. К а ще н ко вмбсть съ понсерваторомъ музея В. П. А ни кинымъ и служителемъ Зоологическаго музея Д. Векшиным ъ посьтилъ Барабинскія озера съ цълью изсльдованія глистной эпизоотіи рыб́ь. При этомь было соо́рано 68 шкурокт, птицъ, изъ которыхъ 42 экземпляра въ видъ чучел'ь и шкурокт хранятся въ настоящее время въ Зоологическомъ

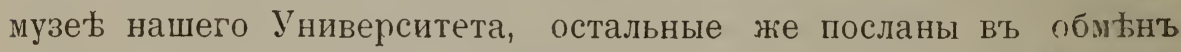
иа другіе зоологическіе препараты въ З о ологич иск і й $/$ уз ей Академ і и Наукъ въ С.-Пете роб ургь, проф. М. А. Мензб и р у въ Москв'ь и другимъ лицамъ и учрежденіямъ. Отчетъ объ этой поъздкь опубликованъ проф. Н. Ө. Ка ще н к о въ „Извђстіяхъ Императорскаго Томскаго Университета“ за 1891 г. подъ заглавіемъ „Отчетъ объ изсльдованіи глистной эпизоптіи рыб́ въ Барабинскихъ изерахъ.". О ходь этой поъздки и пбъ орнитологическихъ сборахъ во время ея я считаю нелишнимъ изъ отчета выписать здъсь сльдующія данныя.

Экспедиція вығхала изт. Томєка 14-го іюля, возвратилась 4-го августа, употребивъ на поъздку ровно три недъли 160 -го іюля члены экспедиціи прибыли на оз. Убинское и остановились въ ближай- 
шсмъ къ озеру населенномъ пункть с. Карианском. Съ 18-го іюля по 23-е экспедиція работала на оз. Чаны и остановилась въ дер. Кваининой, непосредственно на берегу Квашинскаго залива озера. Отсюда производились нъсколько разъ дпвольно отдаленныя экскурсіи вдоль береговъ и на острова Холостой, Тюринъ, Затычкинъ, Шелудяковъ и др. При этихъ экскурсіяхъ добыто 35 водныхъ птицъ, преимущественно чаекъ и утокъ. Съ 23-го по 28-ое іюля экспедиція работала на оз. Сартланъ, остановившись въ с. Таскиев въ 5 в. отъ озера. Въ отношеніи пріобрьтенія водныхъ птицъ она здъсь была менъе счастлива и добыто всего 14 чаекъ, ; утки и одна гагара. Обширныя пођздки по Сартлану были совершенно невозможны за отсутствіем'ъ подходящихъ лодокъ. Съ 29-го іюля по 2-ое августа экспединія снова была на оз. Убинскомъ, пстановившись в' расположенномъ в` 4 в. отъ берега c. Карианскомо. Здъсь было добыто 16 чаекъ, 23 утки, 2 гагары и 5 лысухъ.

Орнитологическіе сборы во время этой побздки въ видъ шкурогъ согласно отчету выразились сльцующими цифрами:

Крачегъ (Sterna hirundo L.) . . . . . . . . . : 3

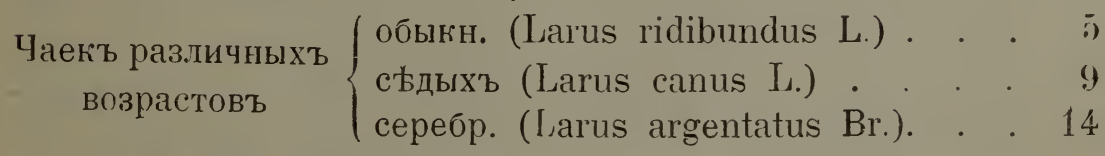

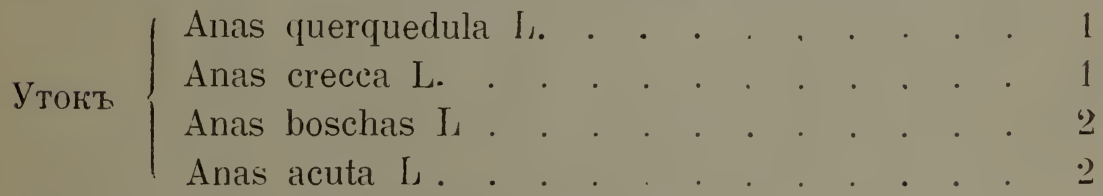

Соксунов эs (Spatula clypeata Boie) . . . . . . . 2

Нырковъь (Fuligula sp.) . . . . . . . . . . . . $7^{*}$ )

Гагаръ (Colymbus arcticus L.). . . . . . . . . . , 1

Лысухъ (Fulica atra L.). . . . . . . . . , . . . 2

Орланивъ (Haliaetus albicilla Gray) . . . . . . . . . . 1

Орловъ-могильниковъ (Aquila imperialis Bechst) . . . 2

Орловъ малыхъ (Aquila naevia Briss.) . . . . . . . $3^{* *}$ )

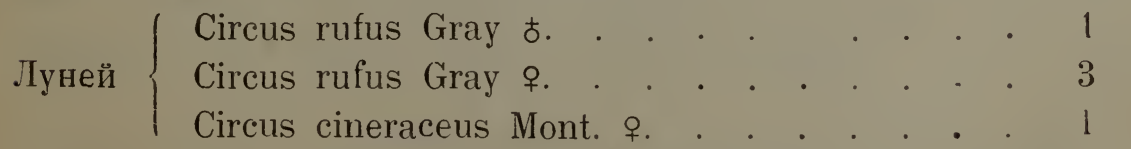

*) IІо моему опредълленію Aythya ferina Linn. u Fuligula fuligula Linn.

**) По опреджнгенію проф. М. А. м е в з би ра и моему Aquila clanga Pall. 
Кроншнеповъ (Numenius arquatus L.) . , . . . . . 3

Куликовъ ( $\mathrm{L}$ mosa aegocephala $\left.\mathrm{L}_{\Lambda}\right)$. . . . . . . . . 2

Улитъ (Totanus fuscus Briss.). . . . . . . . . . 1

Phalaropus sp. . . . . . . . . . . . . . $2^{*}$ )

Всего шкурокъ. 68

\section{II. Поъздка 1899 г. въ Барабинскую степь.}

Лћтпмъ 1899 г. проф. Н. Ө. К а ще н ко со мною предпринялъ пођздку съ цблью собиранія зоологическаго матеріала по линіи Сибирской ж. д. оть Красноярска до Омска. Въ качествъ коллектора и прецаратора насъ сопровожљаль служитель Зоологическаго музея М. Тол м а ев т. При коллектированіи зоологическаго матеріала и консервированіи его содъйствовали во время этой поғздки прозекторъ С. М. Чугунов в и его сынъ М. ('. Чугуновъ, тогда еще воспитанникъ Томской Гимназіи, а нынъ врачь. Нъсколько птицъ во время этой поъздки препарированы студентомт, К. А. Ш а в ров ы м . Вэ, предълахъ стени (ст. Коченево-Омскъ) во время этой побздки соџрано 175 птичьихъ шкурокъ и два скелета (Colymbus arcticus Linn. и Podi eps cristatus Linn.) **).

Предварительный отчетъ объ орнитологическихъ наблюденіяхъ, произведенныхъ въ район' Сибирской ж. д. за әту әкспедицію мною опубликованъ в’ъ Ornith. Jahrb. ХІІ. 1902. подъ заглавіемъ „Ornithologisches von der Sibirischen Eisenbahn."

Веденіе орнитологическаго дневника во время этой побздки было проф. Н. $Ө$ Ка ш е н ко поручено мнъ. Изъ него я привожу сльдующія данныя о ходъ поћздки и орнитологическихъ сборахъ.

$\mathrm{B}_{\mathrm{s}}$ распоряженіи экспедиціи на все время льтняго каникулярнаго времени по распоряженію Г. Министра Путей Сообщенія находился вагонъ № 404 (Ш класса) Средне-Сибирской ж. д. Вечеромт, 6.го іюня выбхали изъ Томска. Съ, 8.го по 14-ое іюня наш'ь вагонъ стоялт. на ст. Јбинской. Въ ближайшихъ окрестностяхъ этой станціи ежедневно коллектировали. Въ особенности я обращалъ вниманіе на пернатое населеніе т. н. „ряма“ (торфяного болота, покрытаго карликовыми соснами) и находящагося

*) A пменно Phalaropus lobatus L. (-hyperboreus Linn'.

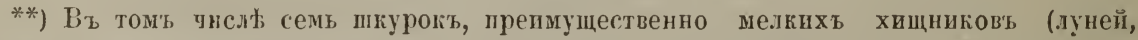
к обчика, пустельгн) собраны въ пкр. г. Гаинска гт. Чугуновыми 29-го и 30-го іюля 1899 г. Остальные члены экспедиціи в'ь г. Капнск' не забзжали. 
невдалекь оть станціи Уракова озера. Вт, первом пьли еще Sylvia sylyia fuscipilea landb. II слышны были меланхолическіе звуки Emberiza leucocephalos Gnıel. Особенно меня удивило здыс отсутствіе дроздювъ п дятловт. На озерь птицъ иыло также немного. Фауна открытой степи и березовыхъ колковъ казалась болье разноюбразной. Здћсь мы находили коростелей, перенелку, Pratincola maura Pall., Anthus richardi Vieill., кроншненовъ, жкелтую трясогузку, жкаворонка и журавлей съ одной стороны, а съ другой какъ обитателей березовыхъ рощицъ въ степи кукушку, дрозда-рябинника, Sylvia sylvia fuscipilea Landb., Anthus trivialis linn. и Emberiza aureola Pall. Вдоль полотна жельзной дороги мы часто наблюдали Saxicola oenanthe Linn., обыкновенную пустельгу, шегловъ и Charadrius dubius Scop.

9-го іюня къ вечеру я со служителемъ на лошадяхъ поьхалъ къ находящемуся въ 16-19 верст. оть станціи Убинскому озеру (,морю“" мћстныхъ жителей), гды; мы остановились на заимкь П, Кабанова. По дорогь туда въ березовыхъ рощицахъ видьль галокъ, орловъ-могильниковъ, косала, кукушку, пустельгу, сьрыхъ воронъ. Чъмъ болће мы приближались къ озеру, тьмъ чаце сталъ раздаваться крикъ кроншнепа. На расположенной вдоль дороги недалеко отъ заимки пашнє паслась стайка Larus canus niveus Pall., подбиравшихъ насбкомыхъ. Красивыя птицы рқзко выдьлялись на черномъ фон' недавно вспаханной почвы. Близъ озера летали и бъгали во множеств'b Vanellus vanellus linn. и Clıaradrius dubius Scop. Отовсюду лоносились звуки выпи (Botaurus stellaris Linn.). Ея мычаніе раздавалось впродолженіе всей ночи, утромь и даже днемъ. Здъсь впервые я услышаль надъ собою хохоть великольпньйшей изъ нашихъ чаекъ, самой большой изъ нихъ, хохотуньи (Larus argentatus cachinnaus Pall.). Кромъ нея здьсь гньздятся Larus canus niveus Pall. и Larus ridibundus Linn. Весьма обыкновеннымъ хищникомъ является и здьсь Circus aeruginosus Linn. Изъ мелкихъ пернатыхъ записаны Motacilla tlava beema Sykes, Acrocephalus sp. (убитыхъ экземпляровъ я не могъ найти въ камышахъ), Sturnus vulgaris poltaratzkyi Finsch., Hirundo rustica Linı.; очень обыкновенны утки разныхъ породъ и Anser anser Limn.; Cygnus eygnus Linn. по сочб́щенію гнжздится на озерь. Очень часто встрьчаются Colymbus arcticusLinn. и Podiceps cristatus Linı., Pavoncella pugnax Linn., Limosa limosa Linn. Близъ заики въ березовой рощиц́ водится Pica pica bactriana Bonap. 
Во время экскурсій близъ ст. Убинской во время посльднихъ дней нашего пребыванія были замьчены и частью добыты:

Gallinago gallinago Linn., Falco vespertinus Limn., Anthus trivialis Linn., Emberiza leucosephalos Gmel., Saxicola oenanthe Linn., Acrocephalus schoenobaenus Linn., Oriolus oriolus Linn. Colneus monedula collaris Drumm., Turdus pilaris Linn., Motacilla alba Linn., Emberiza aureola Pall. и Passer montanus Linn.

Ночью съ 14-го на 15-ое іюня мы изъ Убинской перебхали на сг. Татарскую.

Станція Татарская (15-ое по 22-ое и 26-ое по 29-ое іюня).

Пернатое населеніе окрестностей этой станціи съ небольшими озерами и березовыми рощицами въ степи состоитъ изъ сльдующихъ видовъ:

Passer domesticus Linn., Passer montanus Linn., Emb. aureola Pall., Motacilla flava beema Sykes, Motacilla citreola Pall., Anthus trivialis linn., Anthus richardi Vieill., Alauda arvensis Linn., Pratincola maura Pall., Cyanecula coerulecula Pall., Hypolais salicaria Pall., Acrocephalus schnenobaenus Limn., Oriolus oriolus Linn., Sturnus vulgaris poltaratzkyi Finsch, Cuculus canorus Linn., Lanius minor Gmel., Hirundo rustica Linn, Phylloscopus trochilus septentrionalis Brehm., Dendrocopus leuconotus cirris Pall.

На озерахъ изъ утокъ добыты лишь Anas boscas Linn. и Querquedula querquedula linn., изъ чаекъ и крачекъ здъсь дпбыты во множеств въ меньшемъ количеств' здьсь водятся Larus ridibundus Linn., Sterna hirundo Linn. и Hydrochelidon nigra Linn. Прибрежнүю зону озеръ населяють здъсь, кромь нбкоторыхъ упомянутыхъ выше воробьиныхъ Pavoncella pugnax Linn., Limosa limosa Linn., Vanellus vanellus L. Въ степи найдены Numenius arcuatus lineatus Cuv., Perdix perdix Linn., Lagopus lagopus Linn., Coturnix coturnix orientalis Bogd., слышенъ крикъ Crex crex Linn. и характерное „фит-фит“ водяной курочки (Ortygometra maruetta Linn.). Добытъ Trypanocorax frugilegus tschusii Hart. Въ березовыхъ рощахъ водятся Dendrocopus minor pipra Pall. и Gecinus canus Gmel. (по сообщенію охотниковъ). Мы добыли Turtur ferrago Eversm. и слышали мурлыканіе козодоя (Caprimulgus europaeus Limn.). Изъ хищныхъ добыты Circus aeruginosus Linn., Circus pygargus Linn., Aquila nipalensis Hodgs., Falco vespertinus Linn., Falco timnunculus Linn., Falco subbuteo Linn. По разсказамъ 
встрбчаются Aquila melanaëtus Linn., Astur palumbarius Linn., Ardea cinerca Linn., Grus leucogeranus Pall., Grus grus Linn., Bubo hub) sibiricus Schl. et Sus.

Станція Кіличинская (23-е и 25-ое іюня). Псгола прайне неблагопріятствовала сборамъ, шелъ дождь и градъ лри сильнћйшемъ вътрь, такъ что 24-ое провели въ Омскъ, гдъ хотьли осмотрьть коллекціи Занално-Сиоирскаго Отдђла Имп. Руескаго Географ̆.ическаго Общества. Къ великому огорченію нашему музей всльдстғіе ремонта был'ъ закрытъ.

Въ Калачинской, расположенной по р. Оми, изъ штиць найцены большія стаи Trypanocorax frugilegus tschusii Hart, Corvus cornix sharpei Oates, Saxicola oenanthe Limn., Alauda arvensis Linn., Aquila chrysaëtos Linn., Hirundo rustica Linn, домашніе воробьи и голуби въ церевнъ, колюнія Clivicola riparia linn. на Оми, Totanus ochropus Linn., Charadrius dubius Scop., Vanellus vanellus Linn., Sterna hirundo Linn., Larus minutus Pall. Проф. Н. Ө. Кащенко въ березовомъ и тальниковомъ колк' нашелъ семью Cyanistes cyanus Pall., изъ которой добылъ четырехъ. Крестьянинъ доставилъ живого филина (Bubn bubo sibiricus Schl. et Sus.).

На ст. Тампиской проф. Н. Ө. К а ще н к о вечеромъ 23-го іюня получилъ телеграмму, вызвавшгю его въ Томскъ, и ночью мы побхали на ст. Коченево, гдь веденіе экспедиціи былп возложено на меня. Изъ членовъ экспедиціи остался со мной лишь служитель М. То лм а евъ; съ нимъ мы собирали и препарировали на ст. Коченево, а затьмъ переьхали въ восточныя части Томской губ́. Матеріалъ, собранный здъсь на ст. Ижнорской, Красной и Судженкъ не включенъ въ настоящую работу.

Ст. Кіченево (3С-е іюня по 5-е іюля). Возвышенгая, степная мъстность, озера птсутствуютъ. Близъ станціи прудъ для снабженія паровозовт водою. Много пашенъ. Въ степи мъстами березовыя рощицы. Ручеекъ, питающій прудъ, рбъка Б. Камышенка, на которой стоитъ село Коченево, и рбчка Чикъ. Село Коченево нъсколько западнъе дер. Тыришкиной, считаемой восточнымъ пунктомъ въ Барабинской степи *). Характеръ авифауны окрестностей этого села сльдующій.

*) См. $r$. Helmersen. (Beiträge zur Kenntnis des russischen Reiches Bd. 14 1. 15). По его мнжнік на западь эта степь простирается до Омска, на востокь до „ Пірутыхъ логовъ" или до қер. Тыришкиной. 
На озеръ-прудъ близъ станціи найдены: Numenius tenuirostris Vieill., Vanellus vanellus Lmnn., Charadrius dubius Scop, Gallinago gallinago Limn., Tringa subarcuata Güld, Tringa minuta Leisl., Tringa subminuta Midd., Terekia ctnerea Güld, Pavoncella puguax Limn., Totanus calidris Linn., Totanus stagnatilis Bechst., Totanus glareola Linn., Sterna hirundo Limn., Larus minutus Pall., Mareca penelope Lim., Dafila acuta Linn.

Побздка въ дер. liaзаков! на р. Чикъ, предпринятая мною 1-го іюля, уббдила меня въ отсутствіи грачей. Я видьлъ и частью добылъ Anas boscas Linn., Grus grus Linn., Circus pygargus Linn., Vanellus vanellus Linn., Emberiza schoeniclus Limn., Hirundo rustica Limn.. Totanus glareola Limn., Charadrius dubius Scop., Totanus ochropus Linn., Motacilla flava beema Syk.

По ручейку, питающему озеро-прудъ близъ станціи добыта Cyanecula coerulecula Pall.

Въ степи и по колкамъ въ ней найдены:

Turtur ferrago Eversm., Falco vespertinus Iinn., Anthus richardi Vieill., Emberiza citrinella Linn., Pratincola maura Pall., Saxicola oenanthe Linn., Cuculus canorus Linn., Coturnix coturnix orientalis Bogd., Sturnus vulgaris poltaratzkyi Finsch, Hypolais salicaria Pall., Otus otus Linn., Anthus campestris Iinn., Circus macrurus Gmel., Circus pygargus Linn., Grus grus Linn.

По сообщенію мъстнаго охотника („промышленника") Е. П. Горбунова въ 8 верстахъ отъ села разъ убитъ „черный журавль (Grus monachus Temm.?), пролетомъ встрьчаегся сьрая цапля и иногда поцадаются „красныя утки“ (Casarca casarca Linn.?).

\section{III. Поъздка 1900 г. въ приалтайскія степи:).}

Лвтомъ 1900 г. проф. Н. Ө. Каще н ко сп студентомъ, а нынғ врачемъ А. П. Велижаниным и препаратороиъ М. Толмачевым совершиль пољздку въ приалтайскія степи. Орнитологическія сборы во время этой экспедиціи выразились 135 шкурками и 5 яйцами.

Изъ Томска экспедиція выҺхала 23-го мая. Въ Барнаулъ пріьхали 26 го мая въ 1 ч. дня. Здъск пришлось пробыть трое сутоћъ,

*) Но диевнику проф. Н. Ө. Кащенко, пюбезно предостав.лениому пмъ мнт, и по эгземпянамъ колтекціи, мною опредъвеннымь. 
благодаря трудности добыть тельгу. Вь окрестностяхъ Бацнаула экскурсировали 28-го мая. Изъ Барнаула вывхали 29-го мая въ $9{ }^{1} / 2$ ч. утра, Һхали безостановочно и пріћхали въ д. Сауику близъ Колыванскаго озера 30-го мая въ 12 ч. дня. Здъсь 31-го мая проф). Н. О. Каще нко предпринялт, экскурсію въ степь, среди которой разбросаны отдбльно возвышающіяся скалн. Добыты здысь: Apus pacificus Lath. и Columba rupestris pallida Rothsch. et Hart. Жаворонковъ въ степи много. Вечеромт того жіе дня изъ д. Саушки Һздили на Колыванское озеро, слышали много соловьевъ, видх;ли камышевокъ и, кажется, камышеваго лрозда. Сльдующіе дни дали изъ птицъ: Asio accipitrinus Pall., Erythropus vesperti. nus Limn., перепела, Larus ridibundus Linn., Lanius collurio Linn., Sylvia cinerea fuscipilea Landb., Anthus richardi Vieill., Anthus campestris Linn., Emberiza hortulana Linn., Emb. aureola Pall., Saxicola leucomela Pall., Pratincola maura Pall., Motacilla personata Gould., Anthus trivialis Linn., Sterna hirundo Linn., Numenius arcuatus lineatus Cuv., обыкновенную кукушку, галокъ, Bubo bubo sibiricus Schl. et Sus; экскурсіи ға Колыванское озеро были совершены еше нъсколько разъ. Во время ихъ проф. Н. Ө. Кащ е н ко стрблялъ по корморану, видълъ гоголей, слышалъ камышевку-сверчка (l.ocustella sp.). Въ Саушкъ ластотки деревенскія, воробей домашній, встрьзчется Clivicola riparia Linn, сьрыя вороны, орлы бълоголовые (Aquila melanaëtus Linn.), сърые журавли, кукушка елышна довольно часто, соловьи чрезвычайно многочисленны, перепела слышны постоянно; на Колыванс:бомь озерь видъли розовыхъ скворцовъ, удчда. 5-го іюня проф. Н. Ө. Кащенко видълъ польшого голупоого луня и слышаль пьніе Carpodacus erythrinus Pall., сфотографировалъ гнбздовья Apus pacificus !,ath.

Изғ д. Сауции экспедиція проф. К а ще н ко выбхала 7-го іюня въ $3 \frac{1}{2}$ ч. дня, въ Змьиногорскъ пріьхали въ $5^{1} \frac{1}{2}$ ч. дня. утрпмъ 8-го іюня въ $6 \frac{1}{2}$ ч. выъххли изъ Змбинсгорска и пріьхали въ с. .Током на р. Алеђ въ $3 \frac{1}{2}$ ч. дня. Пернатое населеніе окрест. ностей этого села состоитъ изт сльдующихъ видовъ: larus canus niveus Pall., Vanellus vanellus Linn., Motacilla flava beema Sykes, Falco subbuteo Linn., Turtur ferrago Eversm. и Phylloscopus sp. в], небольшой рошь на берегу рьки, Totanus hypoleucos Linn., Alauda arvensis Linn., Limosa „rufa“, оказавшіяся при опредъленіи novae-zealandiae Gray (на озерћ въ 8-ми в. отъ села), Uragus sibiricus Pall., Hydrochelidon fissipes Pall., Falco tinnun- 
culus Iinn., сьрыя вороны и грачи въ степи въ смышанныхъ сгаяхъ, Spatula clypeata Linn., Querquedula querquedula Linn., Daulias philomela Bechst., Phylloscopus viridanus Blyth., Oriolus oriolus linn., Turdus pilaris Linn., Upupa epops Linn., Pica bactriana Bonap., Sturnus vulgaris poltaratzkyi Finsch, Milvus sp.? Merops apiaster Iinn. на ръчкљ, Charadrius dubius Scop., Sylvia nisoria (по мпему мньнію subsp. nova!), Pelecanus onocrotalus roseus Gmel., Acrocephalus schoenobaenus Linn., Larus minutus Pall., Gallinago major Linn., Gallinago gallinago Linn., Limosa limosa Linn., Numenius arcuatus Linn., Paroncella pugnax Linn., Totanus cal dris Linn., Hydrochelidon nigra Linn., Falco respertinus Linn, Lanius collurio Linn., Carpodacus erythrinus Pall., Cyanecula coerulecula Pall., Apus apus pekinensis Swinh., Fylvia curruca въ вападной формъ., Lanius minor Gmel., Alcedo ispida sibirica Tschusi, Asio accipitrinus Pall. Шо сообщеніямъ мбстныхъ "промышленниковъ“ близъ с. Локтевскаго встрььаются: Aquila chrysaëtos Linn. и melanaëtus Linn., Haliaëtos albicilla Linn, журавли сърые и дрофы.

18-го іюня выбхали пзъ с. Локоть чрезъ д. Новенькую, с. То̣ польное въ д. Бороду.иху, гдъ остановились съ тьмъ, чтобы поохотиться на находящемся рядом'ь большомъ озерћ. Дождь помћшаль этому, и только на короткое время А. II. Велижанинъ съґздилъ на озеро, откуда п привезъ Aythya ferina Linn. и 'Totanus calidris Linn. На озерь были замғчены Glottis nebularius Gunn. и Terekia cinerea Güld. Подъьжая къ Бородулихь, уюили Lanius minor Gmel.

Утромъ 19-го іюня, около 9 часпвъ выбхали из' Бороду.ицхи и чрезъ Жіерновку пріьхали въ IІІу.иб! около 2 ч. дня. Немного не добзжая поселка на р. Шульбинкъ видъли нъсколько Coracias garrulus linn.

Въ пос. Шу.иби (на р. Иртышъ) экспедиція пробыла до утра 25-го іюня. Орнитофауна окрестностей поселка состояла изъ сльдующихъ видовт:

Cyanistes cyanus Pall., Cyanecula coerulecula Pall., Sylvia curruca affinis Blyth, Lanius minor Gmel.. Anthus campestris Limn., Charadrius dubius Scop. Oriolus oriolus Linn., Sternula minuta Linn., Sterna hirundo Linn., Haematopus ostralegus Linn., Turtur ferrago Eversm., Caprimulgus europaeus Linn. На Иртышћ здбсь видъли Motacilla personata Gould., въ посельь гнъздится ласточка едер- 
венская, воробей обыкновенный и полевой, видљли сърую ворону и сороку. Непрепарғрованной осталась добытая здысь Sylvia cinerea fuscipilea Landb Видєли Buteo sp.?, галокъ.

Изъ пос. ЛІульбы 26-го іюня выҺхали въ 7 часовъ утра, а вт 12 ч. дня прівхали въ с. Убинское на р. Убъ и Иртышб (между Семипалатинскомъ и Усть-Каменогорскомъ).

Изъ окрестностей этого села въ коллекціи сльдуюп, ве виды пернатыхъ: Emberiza luteola Sparrm., Hypolais salicaria Pall, Lanius minor Gmel., Alcedo ispida sibirica Tschusi, Pratincola maura Pall., Motacilla flava beema Syk., Charadrius dubius Scop., Pastor roseus Linn.. Hydrochelidon nigra Linn., Vanellus gregarius Pall., Trypanocorax frugilegus tschusii Hart., Falco subbuteo Linn. Кромь того здьсь были замьчены: иволга, Totanus hypoleucos Linn?; изрьдка попадались сьрыя вороны и галки, Motacilla personata Gould., Sternula minuta Linn., Sterna hirundo Linn., Buteo sp.?, Turtur ferrago Eversm, Erythropus vespertinus Linn., Otis tetrax Linn., слышали перепела; и здъсь найдены: Cyanecula coerulecula Pall., Mılvus sp., Haematopus ostralegus Linn.

Изъ с. Убинскаго утромъ 4 го іюля выбхали. а въ Тюмскъ члены экспедиціи вернулись 8.го ію.юя

\section{IV. Поъздка 1902 г. въ Кулундинскую степь и прилегающія мъст- ности Семипалатинской области.}

Лътомъ 1902 г. Совътт Императорскаго Томскаго Университета командироваль меня съ цълью коллектированія позвоночныхъ животныхъ въ Кулундинскую степь и прилегающія мьстности Семипалатинской области. Въ качеств вождалъ служитель Зоологическаго кабинета М. Д. Т о л м а ч е в т. Въ этой поъздкь принимали участіе и оказывали содъйствіе при собираніи матеріала и его препарированіи два воспитанника Томскаго Реальнаго Училица И. Н. К и р илл о в ъ и Г. А. Неведровъ. Орнитологическія поступленія въ нашъ музей посль⿱宀 этой побздки выразились $110^{\circ}$ шкурками, -130 муміями *), однимъ гнъдомъ и 13 яйцами кромь трехъ череповъ.

*) По способ́y д-pa Fülleborn'a (Zool. Anzeiger 수 634 Ornithol. Nonatsherichte 1901 ํㅜ 4). 
Прєдварительный отчетъ объ этой пођзакъ мною опубликөванъ въ Ornith Jahırb. XV. 1904 подъ заглавіем’ „Vorläufiger Bericht über eine im Sommer 1902 in die Kulundinsche Steppe und die angrenzenden Teile des Ssemipalatinsker Gebietes unternommene Reise".

Служеб̆ныя обизапности въ Реяльномъ Училищь задержали меня до 8 го іюня в’ь Томск'. Вт этотт день вт, 10 часов’ь утра

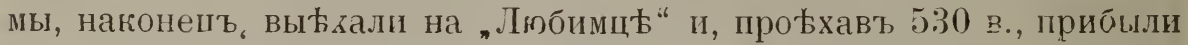
11-го іюня въ 4 ч. дня въ с. Камень иа Оби. Отсюда на лошадяхъ пробхали черезъ д. Гонохову въ дер. Пльтникову; куда прибыли н)чью около часа.

По дорогь видьли Motacilla alba Linn. и Motacilla flava beema Sykes, Vanellus vanellus Linn., Anthus richardi Vieill, Alauda arvensis Linn., Circus cyaneus Linn., Querquedula querquedula Linn., Nettion crecca Linn., Anas boscas Linn. и Dafila acuta Linn. Самець шилохвоети гналея за самкой, обђ птицы пронеслись низко надъ нашихъ экипажемъ, самець старался при этомъ схватить самку клювомъ на лету.

Дер. ПІ.опникови (12-е по 15-е 1юня). Пернатое населеніе состояло здьсь изъ Passer domesticus Linn. и Hirundo rustica Linn. Въ рощъ близъ деревни нашли колонію грачей, удодл. кукушку, Falco vespertinus Linn. и Glaucidium passerinum Linn.

Въ березовыхъ колкахъ вболизи геревни найдены Oriolus oriolus Linn., Carpodacus erythrinus Pall,, Emberiza aureola Pall., Sylvia sylvia fuscipilea landb.. Turdus pilaris Linn., Muscicapa grisola Linn., Anthus trivialis Linn., Pica bactriana Bonap., Cuculus canorus johanseni Tschusi и Falco vespertinus obscurus Tschusi.

Въ степи найдены: Numenius arcuatus lineatus Cuv., Alauda arvensis : inn., Anthus richardi Vieill., Crex crex Lınn., Grus grus Linn., Coturnix coturnix orientalis Bogd., Limosa limosa Linm,, Buteo vulpinus Licht. и Glareola melanoptera pallidogularis sulssp. nova.

По болье сырымъ мъстам'є, вблизи в"ды мы замбгили: Motacilla flava beema Sykes, Mntacilla alba I inn.. Motacillla citreola Pall., Emberiza aureola Pall., Vanellus vanellus Linn., Grus grus Linn. и Circus pygargus Limm.

Hа озерахъ близъ названной деревни: Dafila acuta Linn., Anas boscas L'nn., Querquedula querquedula и Nettion crecca L., Cygnus cygnus Limu., Anser anser Linn., Tadorna tadorna Linn., 
Colymbus areticus Linn. Надт водон носились Clivicola ripara Linn., Hydrochelidon nigra Linn. и fissipes Pall., Sterna hirundo Limn., larus minutus Pall., и ridibundus Linn. Larus argentatus cachinnans Pall. на маленькихъ озерахъ отсутствовала, но найдена на большихт.

Изт, куликовт, здъсь встрьчаются: Limosa novae-zealandiae Gray и Limosa limosa Linn., Vanellus vanellus Iinn, Totanus calidris Linn., Terekia cinerea Güld., Totanus stagnatilis Bechst., Charadrius dubius Scop. и Gallinago major Linn. Pavoncella pugnax linn. только пролетомт.

Камышевыя заросли озерь здъсь населены сльдующими видами: Botaurus stellaris Linn., Podiceps nigricollis Brehm, Podiceps cris. tatus linn., Podiceps auritus limn. На всъхъ озерахъ весьма обыкновенны Fulica atra Linn. и ('ircus aeruginosus linn.

Подъ речеръ 15-го іюня вы вхали изъ Плотниковой чрезъ д. Ключи въ с. Тюменцево, гдь провели ночь. По дорогъ около Ключей видъли много сизоворонокъ, которыя преимущестьенно усаживаются на служившихт, зимою въхами кольяхъ по дорогамъ въ степи. Тутъ же видъли и добыли кобчиковъ. Утромъ 16-го іюня изъ с. Тюменцева добхали до с. Вылкова. Дорога вела первоначально довольно однообразной пустынной степью мимо небольшихъ озеръ, но дальше степь покрыта роскошной травянистой растительностью. Сћнокосъ уже начался. Въ степи видъли много Pratincola maura Pall., Anthus richardi Vieill., желтыхъ трясогузовъ. По мърь приближенія къ с. Вылкову степь становится бглће возвышенной, озер'ь не видно, но зато на южномъ горизонтъ виднъется лъсъ, къ которому мы несемся на добрыхъ лошадяхъ, окруженные облакомъ пыли; это великольпный сосновый боръ. На коль опять усьлась сизоворонка, пьніе иволги доносится изъ бора: пробзжая его, мы вспугнули кормившуюся на дорогь горлицу (Turtur ferrago Eversm.).

Село Bы.пюво (16-е по 22-е іюня) раскинулось по краю Кулундинскаго бора на берегу р. Кулунды. Въ деревнћ изъ птицъ можно было замътить домашнихъ гслубей, деревенскую ласточку, воробья обыкновеннаго и полевого, Motacilla alba Linn. Не далеко отъ деревни всюду можно было замьтить сърыхъ воронъ, галокъ, грачей и сорокъ.

Пернатое населеніе Кулундинскаго бора имъетъ сльдующій составъ: Tetrao tetrix Linn, Perdix perdix Linn., Oriolus nriolus 
Linn., Pyrrhula pyrrhula Linn., Ruticilla phoencurus Linn., Emleriza leucocephalos Gmel., Grus grus Linn., Anthus trivialis Linn., Cranius minor Gmel., Cuculus canorus johanseni Tsch., Upupa epops Linn., Carduelis carduelis major Tacz., Turdus pilaris Linn., Turdus musicus Linn, Parus major Linn., Parus borealis baicalensis Swinh., Dryocopus martius Linn., Dendrocopus major cissa Pall., Caprimulgus europaeus Linn., Turtur ferrago Eversm.. Falco subbutéo Linn., Milvus melanotis Temm. et Schl., Hierofalco sacer Gmel., Pica pica bactriana Bonap., Apus apus pekinensis Swinh., Aquila melanaëtus Linn.

Авифауна озеръ близъ этого села состоитъ изъ Anas boscas Linn, Clangula clangula Linn., Totanus calidris Linn, Terekia cinerea Güld., Gallinago megala Swinh., Charadrius dubius Scop., Limosa limosa Linn, Hydrochelidon fissipes Pall., Sterna hirundo Linn, Vanellus vanellus Linn. Въ степи близъ села найдены Alauda arvensis Linn., Pratincola maura Pall., Coracias garrulus Lim. и Emberiza hortulana Linn.

Сдавъ два ящика съ препаратами для отправленія въ Томскъ, мы 22-го іюня выбхали изт, с. Вылкова чрезъ с. Овелкино и д. Мысы въ д. Тистоозерскую (она॰же Шаравина). Дорога ведетъ вдоль Кулундинскаго бора, съ съверной его стороны. по степной мъстности, Утки и чайки разныхъ видовъ видны во множеств по озерамъ, изъ которыхъ нбкоторыя, намр. Поддорожное и Бакланье, очень красивы. Въ степи „на тьчкахъ, опять сидять кобчики и сизоворонки. Передъ д. Мысы мы пересъкаемъ очень узкій въ этомъ мысть боръ. За д. Мысы тамъ и сямъ въ стеши виднбются березовые колки, мбстами степь переськается небольІшими ложками.

Дер. Чистоозерская (23-ье іюня по 1-ое іюля). Близ'ъ деревни въ рощъ найдены: Passer montanus Linn., Parus major Linn., Muscicapa grisola Linn., Oriolus oriolus Linn., Lanius minor Gmel. Роща служитъ мћстомъ гнЊздовья грачей.

Орнитофауна стени и островныхъ льсковъ г кустарниковъ В'ъ степи состоитъ изъ сльдующихъ пернатыхъ: Tetrao tetrix Limn., Perdix perdix Linn., Lagopus lagopus Linn?., Bubo bubo sibiricus Schl. et Sus, Otis tarda Linn., Otis tetrax Linn., Grus grus linn. Anthropoides virgo Linn., Falco vespertinus Linn., Falco tinnuncuus Limn., Pastor roseus Linn, Aegithalus stoliczkae Hi ne, Vultur monachus Linn., Aquila melanaëtus Linn:; Aquila chrysaëtos Limu. 
Haliaëtos albicilla Limn Bъ качеств' зимнихт, пось⿱тигелей степи по разсказамъ мьстныхъ жителғй можно привести: Npctea scandiaca Linn. и Melanocorypha yeltoniensis Forst. Берега озеръ въ окрестностяхъ этой деревни населены: Limosa limosa Linn., Motacilla alba Linn. и flava beema Sykes, Motacilla citreola Pall., Emberiza aureola Pall., Tringa minuta Leisl, Acrocephalus agricolus Jerd., Acrocephalus schoenobaenus Linn, Acrocephalus arundinaceus Linn, Cyanecula coerulecula Pall., Locustella certhiola Pall. Totanus stagnatilis Bechst., T. hypoleucos Linn., T. ochropus Linn., T. calidris Linn. и Pavoncella pugnax Linn. На озерахт масса пернатыхъ; здъсь найдены: Fulica atra Linn., Botaurus stellaris Linn, Podiceps cristatus Linn., Podiceps auritus Linn., Podiceps nigricollis Brehm., Casarca casarca Linn., Tadorna tadorna Linn., Netta rufina Pall.. Aythya ferina Linn, Dafila acuta Linn., Spatula clypeata Linn., Mareca penelope Linn., Chaulelasmus streperus Linn., Querquedula querquedula Linn, Nettion crecca Linn, Erismatura leucocephala Scop., Clangula clangula Linn., Ardea cinerea Linn., Circus aeruginosus Linn., Mergus albellus Linn., Mergus merganser Linn.. Anser anser Linn., Acrocephalus arundinaceus Linnı., Acrocephalus agricolus Jerd., Locustella locustella straminea Ssew., Larus argentatus cachinnans Pall., Larus ridibundus Linn., Larus canus niveus Pall, Larus minutus Pall, Sterna hirundo Linn., Hydrochelidon fissipes Pall., Hydrochelidon nigra Linn., Colymbus arcticus linn., Anser albifrons Scop. по сообщенію мбстныхъ жителей ежегодно осенью посьщаетъ озера.

Изъ д. Уистоозерской мы вы'ьхали въ $3 \frac{1}{2}$ ч. дня. Дорога вела мимо изсльдованныхъ нами озеръ Рыбальнагп, Артельнаго, Утичьяго и Грачева и, пробхавъ 15 верстъ, мы прибыли въ с. Камыиенку. Хотя я предполагаль немедленно ьхать дальше, пришлось ночевать, такъ какъ нельзя было получить трезваго ямщика! Въ степи я видњљъ двухъ подорликов'ъ (Aquila clanga Pall.) и Circus pygargus Linn. Степные коньки (Anthus richardi Vielll.) все чаще и чаще стали намъ попадаться. Ночью въ с. Камышенкъ почти непрерывно раздавались характерные звуки Oitygometra maruetta Leach. Въ 8 часовъ утра 2-го іюля намъ, наконецъ, подали лошадей и мы побхали по чрезвычайно однообразной степи къ д. Степному Кучуку, расположенной на ръчкъ того же наименованія. Озеръ почти не видно. Кое-гдь болье низкія мЕста, остатки высохшихъ озеръ и песчаные бугры-кур- 
ганы, покрытые рб̆дкою растительностью, гланнымъ обрразомъ полынью, въ слабой степени разнообразятъ монотонный ландшафтъ. Здћсь намъ пришлось полюбоваться маревомъ: на горизонть передъ нами предстали горы!.. Въ деревнь намъ сейчасъ же дали новые экипажи и мы въ тотъ же день пріъхали въ цер. Нижній или Бархампвскій Кучукъ, расположенную на томъ же Степномъ Кучукь верстахъ въ 3 отъ его устья въ совершенно безлџсной степи.

Дер. Нижній Кучукб. (2-е по 8-е іюля). Вб́лизи человьческаго жилья найдены: Passer domesticus Linn., Passer montanus limn., Hirundo rustica limn., Dendrocopus major cissa Pall., (Bubo bubo sibiricus Schl et Sus. въ невпль), Tadorna tadorna Limn.

Въ степи найдены: жаворонки обыкновенные, тиркушки, 11зъ луней Circus macrurus Gmel. и pygargus Limn, Anthus campestris Limn., Mntacilla flava beenı Sylies, Otis tetrax Limn., Vanellus vanellus linn., Vanellus gregarius Pall. Hypolais salicaria Pall., Coracias garrulus Iimu., Numenius arcuatus lineatus Cur., I tanius minor Gimel., Oriolus oriolus Linn, Asio accipitrinus Pall.

По р. Степному Кучуку и близъ его устья: Clivicola riparia Linn., Charadrius dubius Scop, Larus canus niveus Pall., Dafila acuta Limn., Recurvirostra avocetta Linn., Tadorna tadorna I,imn., Casarca casarca ímn, Glareola melanoptera Nordm.

4-го іюля я посътиль устье р. Солоновки и пользующійся нбкоторой извьстностью „курорть“, располпженный 110 рьчкь и состоящій изъ ньсколькихъ киргизскихъ юртъ. Во время этой поғздки видъль лишь Alauda arvensis linn., Motacilla flava beema Syk., Circus pygargus Linn. и Circus macrurus Gmel. Берега озера низкіе, песчаные, покрыты слоемъ мертвыхь, выброшениыхъ волнами озера наськомыхь шириною въ 1/2 аршина (прямокрылыя и жуки), мъстами въ, углубленіяхъ почвы лежатъ побълъвшія, шаровидныя „перекати поле“ (Salsola sp.). Отправленные мною на устье р. Кулунды (дер. Шемолина) И. Кирилловь и М. Т ол м че въ вернулись со сльдующими птицами: Alauda arvensis Limn., Glareola melanoptera Nordm., Difila acuta Iinn., Totanus calidris Linn., Recurvirostra avocetta Limn. Видњли сьрыхъ журравлей и безусп'ьшно стрьляли по орлану-бьлохвосту.

Непосредственно у устья р. Степного Кучука помьщается метеорологическая стапція. Ею и вмьсть съ тظмъ опытной станціею, въ которой изальдуются вода и соли озера, завђдывалъ А. ПI. П е бедев ъ. 
Изъ. Нижняго Кучука вы фхали 8-го іюля въ $4^{3} / 4$ дня. Дорога вела насъ трезъ Со.оновку въ .Текабу.ловъ ауль, оттуда одиообра-

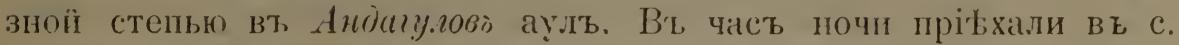
Дуиное, на озерь того же названія. Населеніе этого села малороссы. Утромъ 9-го выъхали изъ, с, Душного и яюло полдня прибыли въ \&. К.июееое. По дорогб увидъли и добыли первыхъ бълокрылыхъ жаворонковъ (Melanocorypha sibirica Gimel.).

Село К.ючевое. (9-е по 14-е гюля) находится на сьверной сторонб т. и. Сьвернаго бора. Вб́лизи села озера. Составъ авифауны окрестностей се.ца такой:

Bъ степи: Alauda arvensis Linn., Melanocnrypha sibirica Gmel., Falco timumculus Linn, I'alco naumanni Fleisch., Otis tarda Linn., Otis tetrax Limn., Turtur ferrago Eversm., Perdix perdix Linn., Lagopus lagopus Linn., Corvus cornix sharpei Oates., Sturnus vulgaris poltaratzkyi Finsch, Coturnix coturnix orientalis Bogd., Anthus campestris Linn., Tetrao tetrix Linn., Motacilla flava flava Linn. и Mot. flava beema Sykes, Pratincola maura Pall., Hypolais salicaria Pall..

Bъ сосновомъ бору: Bubo bubo sibiricus Schll. et Sus., Aquila clanga Pall., Haliaëtos albicilla Linn., Aquila melanaëtıs Linn., Hierofalco sacer Gmel., Falco tinnunculus Linn., Tetrao tetrix L., Turtur ferrago Eversm., Coracias garrulus Linn., Dryocopus martius Linn, Jendrocopus major cissa Pall, Dendrocopus minor pipra Pall., Oriolus oriolus L., Lanius minor Gmel., Saxicola leucomela Pall., Apus apus pekinensis Swinh., Pica pica bactriana Bonap., Upupa epops L, Parus borealis baicalensis Swinh., Sitta uralensis Licht., Corvus cornix sharpei Oates.

Зимою, по сообщенію мћстныхъ жителей, появляются Ampelis garrulus L., Melanocorypha yeltoniensis Forst., Acanthis flammea flammea L., Acanthis hornemannii exilipes Coues, Pyrrhula pyrrhula L., Plectrophenax nivalis Jinn., Nyctea scandiaca L. Случайнымъ посьтителемъ степи яв.яется VuItur monachus Linn.

На озерахъ встрьчаются: Casarca casarca Linn., Tadorna tadorna Limn., Anser anser Limn., Cygnus cygnus Linn., Anas boscas Limn., Chaulelasmus streperus Linn., Dafila acuta Linn., Mareca penelope Linn., Spatula clypeata Linn., Nettion crecca Linn., Querquedula querquedula Linn., Fuligula fuligula Linn., Clangula clangula Limn., Erismatura leucocephala Scop., Mergus merganser Limn., Colymbus arcticus Linn., Fulica atra Linn., Podiceps crista- 
tus Limn., Podiceps auritus Limn., Podiceps nigricollis Brehnn., Numenius arcuatus lineatus Cuv., Tringa temmincki Leisl., Recur. virostra avocetta Linn., Limosa limosa Limn., Totanus stagnatilis Bechst., Cyanecula coerulecula Pall., Anser albifrons Scop.

Изъ с. Ключевого мы выбхали 14-го іюля; побхали мимо д. ఫймагу.я съ малорусскимъ населеніемъ и затђмъ въ степи уже по Семипалатинской области на оверо ЖКе.анды, откуда киргизы отвезли назъ аулами мимо озера Уьянис-ку.иь до мельницъ на озерь Mapa.да. На озерь Чьянгс-куль видъли много Limosa limosa Linn., нбсколько Erismatura leucocephala Scop., кроншнеповъ, утокъ и гусей. По дорогъ въ степи крайне мало птицъ: Alauda arvensis Linn., Anthus campestris Linn., Glareola melanoptera Nordm. На оз. Маралда пріљхали поздно вечеромъ 15-го іюля. На этомъ озерь провели 16-ое іюля. Здбсь найдены: Saxicola oenanthe Limn., Trypanocorax frugilegus tschusii Hart., Recurvirostra avocetta Linn., Larus canus niveus Pall., Larus ridibundus Linn. Въ 6 ч. вечера 16-го вы вхали съ оз. Маралда степью прямо въ Пав.лодаръ (60 верстъ), куда прибыли въ 6 ч. утра на сльдующій день. Шо дорогь видъли Melanocorypha sibirica Gmel., Vanellus vanellus Linn., Anthus campestris Linn., и Clivicola riparia Linn.

Изъ Павлодара въ 7 ч, утра 18-го іюля вығхали на пароходъ „Върный“ вверхъ по Иртышу и въ 7 ч. утра 19-го іюля прівхали на ст. Семиярскую, конечный пунктъ нашего маршрута.

Станц. Семиярския. (19-го по 30-ое іюля). Въ долинб Иртыша на неболь шихь прєсныхъ озерахъ найдены: Casarca easarca Linn., Dafila acuta Linn., Spatula clypeata Limn., Anser anser Limn., Motacilla citreola Pall., Larus ridibundus Linn., Gallinago gallinago raddei Buturl., Totanus ochropus Linn., Totanus stagnatilis Bechst., Phylloscopus tristis Blyth., Cyanecula coerulecula Pall.. Acrocephalus schoenobaenus Linn., Hypolais salicaria Pall., Emberiza aureola Pall., Carpodacus erythrinus Pall., Aegithalus stoliczkae Hume, Cuculus canorus linn.

На Иртышъ найдены; Larus ridibundus Linn., Sterna hirundo Linn., Sternula minuta Linn., Haliaëtos albicilla Linn., :Pandion haliaëtus Linn., Milvus melanotis Temm. et Schl, Clivicola riparia Linn., Haematopus ostralegus Limn., Charadrius dubius Scop., Alcedo ispida sibirica Tschusi

Въ степи: Saxicola nenanthe Limn., Anthus campestris Linn., Falco naumanni Fleisch., Falco subbuteo linn., Otocorys longirost- 
ris sibirica Swinli., Alanda arvensis Limn., Calandrella minor Cab., Melanocorypha sibirica Gmel., Anthus richardi Vieill., Pastor roseus Limn., Trypanocorax frugilegus tschusii Hartert., Corvus cornix sharpei Oates., Coloeus monedula collaris Drumm., Pica pica bactriana. Bonap., Pratincola maura Pall., Circus aeruginosus Isinn., Circus macrurus Gmel., Circus pygargus Linn., Falco vespertinus Limn., Vanellus vanellus Linn., Vanellus gregarius Pall., Glareola melanoptera Nordm., Coturnix coturnix orientalis Bogd., Syrrhaptes paradoxus Linn., Otis tarda Linn., Otis tetrax Linn., Asio accipitrinus Pall.

Въ сосновомъ бору, наз. „Ближнимъ“: Upupa epops Linn., Pica pica bactriana Bnnap., Dendrocopus major cissa Pall., Lanius minor Ginel.

По сообщенію мбстиыхъ охотниковъ; Tadorna tadorna Linn., Botaurus stellaris Limn., Mergus serrator Limn., Mergus merganser Linn., Caccabis saxatilis chukar Gray., Anser cygnoides Pall., Pelecanus sp., Cyguus cygnus Limn., Melanocorypha yeltoniensis Forst., Tetrao tetrix Linn., Lagopus lagopus Linn., Perdix perdix Linn.; Acanthis flammea flammea linn., Acanthis hornemannii exilipes Coues.

Въ 4 часа пополудни 30 іюля показался шедшій изъ Семипалатинска пароходъ „Александръ Невскій“. На немъ мы 2-го августа прибыли въ Омскъ, а 4 го въ Томскъ по жел. дорогъ.

\section{マ. Побздка проф. В. В. Сапожникова 1902 г.}

Во время своихъ ботаническихъ и географическихъ экспедицій проф. В. В. С а п о ж н и к в ъ попутно собиралъ и зоологическія коллекціи. Въ 1902 г. имъ было предпринято изсльдованіе Семирьчья, причемъ зоологическими сборами, главнымъ образомъ, занимался А. П. В е ли ж а н и н ъ и служитель Н. М ез енцевъ. Весьма цвнная орнитологическая коллекція проф. Сапожникова изъ Семирьченскаго края въ непрпдолжительномъ будущемт будетъ мною описана; въ настоящую работу я включилъ изъ сборовъ проф. В. В. Сапожникова лишь матеріалъ, собранный его спутниками въ степяхъ нашего края во время проьзда изг Омска

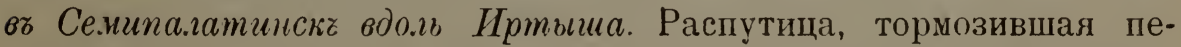
редвиженіе экспедиціи, дала А. П. В е ли ж а н и н у возможность и въ пути заняться коллектированіемъ пернатыхъ, въ результать 
чего оказалась небольшая коллекція, пополняющая наши свђдьнія матеріаломъ, собраннымъ ранней весною.

Эта коллекція состопть изъ 17 шкурокъ и одного черепа и заключаетъ сльдующіе виды: Emberiza lencocephalos Gmel., Emberiza schoeniclus Linn., Calcarius lapponica Linn., Melanocorypha sibirica Gmel., Melanocorypha yeltoniensis Forst., Calandrella brachydactyla longipennis Eversm., Alauda arvensis Limn., Vanellus vanellus Linn., Numenius arcuatus lineatus Cuv., Nettion crecca Linn., Chaulelasmus streperus Linn., Netta rufina Pall.

Јтпцы эти добыты вь сльдующихъ пунктахъ почтоваго тракта межлу Омскомъ и Семипалатинскомъ: ст. Јеб́яжья, ст. Ямышевская, ст. Чернорьцкая-Черноярская, ст. Подпускь, Усть-Заозерская, ст. И.ьинская, ст. Семиярская.

Кромь матеріала, поступившаго въ музей отъ перечисленныхъ выше экспедицій, я пересмотрблт и случайныя поступленія изъ района нашихъ изсльдованій, хранящіяся въ нашемъ музеь. Это 10 чучель разныхъ птицъ изъ окрестностей г. Барнаула, собранныхъ А. П. В ели ж а н и н о ъ въ 1897 и 1899 гг. и пріобрьтеншыхъ музеемъ; шкурка альбиноса бормотушки изъ окрестностей г. Омска, пожертвованная А. П. В е л и жа н и н о мъ въ музей, чучело сърой цапли изъ окрестностей Омска, пожертвованное г-номъ П. О. Ш у л ь п ъ, и наконець, чучело Oedicnemus oedicnemus Iinn., изъ окрестностей Каинска, пріобрђтенное музеемъ отъ II. А. Ш а с т о в с к а го. 
Современное состояніе нашихъ познапій о составђ авифауны степей Томскаго црая и щрилегаюцихъ къ нимь мбстностей можетъ быть выражено слбдующей таблицею:

\begin{tabular}{|c|c|c|c|c|c|c|c|c|c|}
\hline II A :3 B A H I S. & 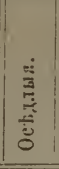 & 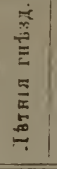 & 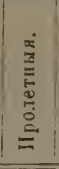 & 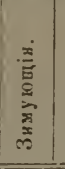 & 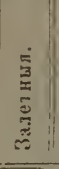 & 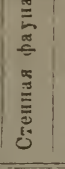 & 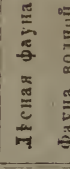 & 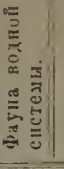 & ІІрим „чанія. \\
\hline 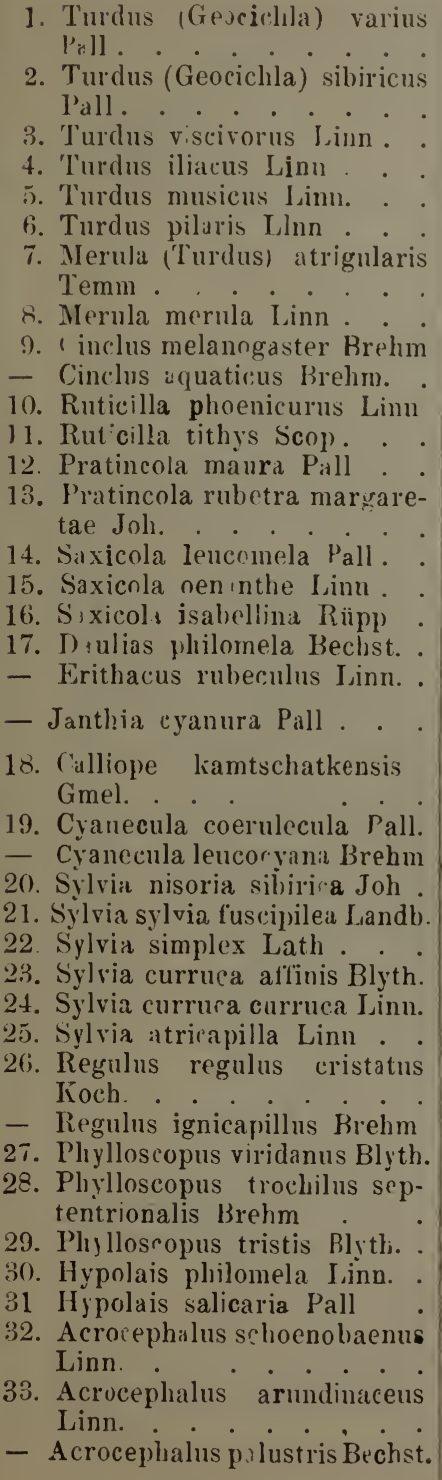 & + & $\begin{array}{l}+ \\
+ \\
+ \\
+ \\
+ \\
+ \\
+\end{array}$ & $\begin{array}{l}+ \\
+ \\
+ \\
+ \\
+ \\
+ \\
+\end{array}$ & & $\begin{array}{l}+ \\
+ \\
+\end{array}$ & $\begin{array}{c}\begin{array}{c}\text { oбит } \\
+ \\
+ \\
+ \\
+ \\
+ \\
+\end{array}\end{array}$ & $\begin{array}{l}+ \\
+ \\
+ \\
+ \\
\\
+ \\
+ \\
+ \\
+ \\
+ \\
+ \\
+ \\
+ \\
+ \\
+ \\
+ \\
+ \\
+ \\
+\end{array}$ & $\begin{array}{l}+1 \\
+\quad 1 \\
1\end{array}$ & 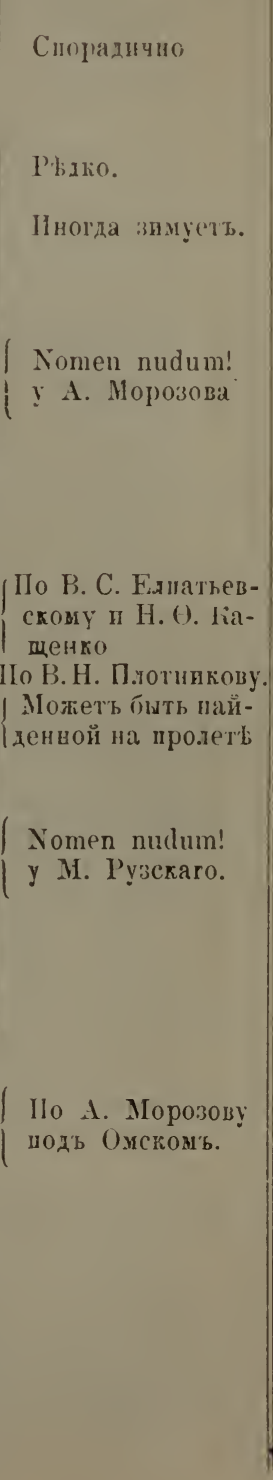 \\
\hline
\end{tabular}




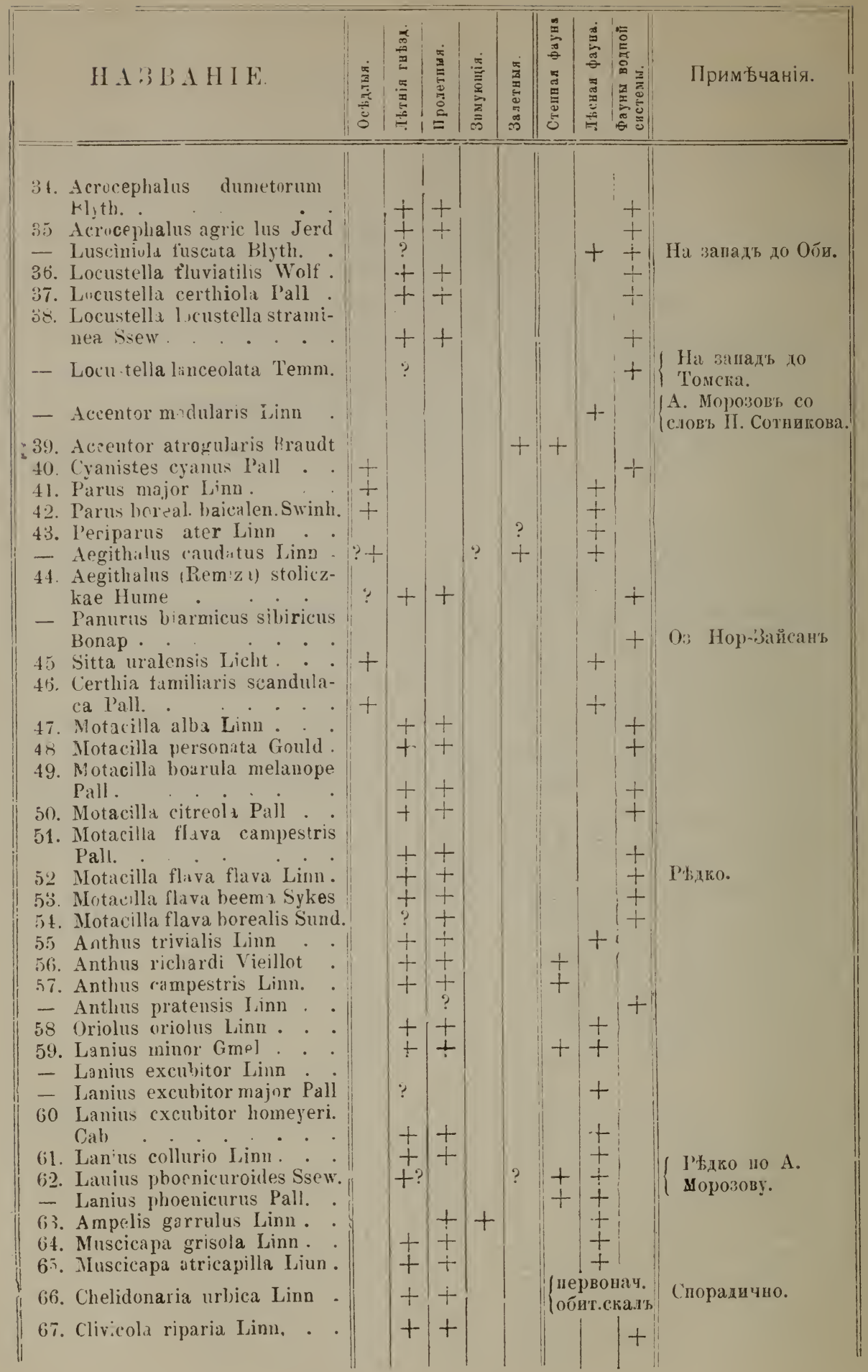




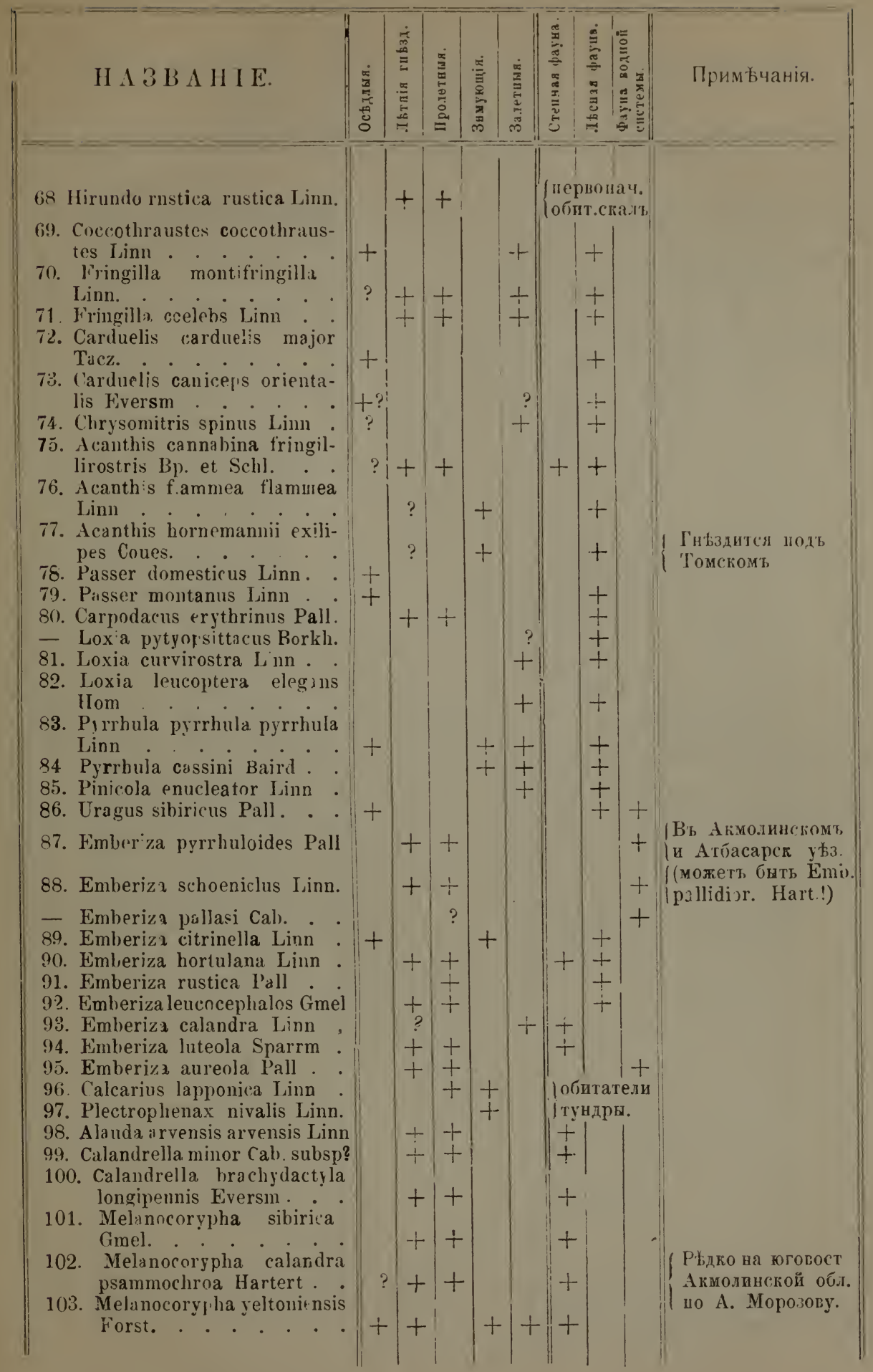




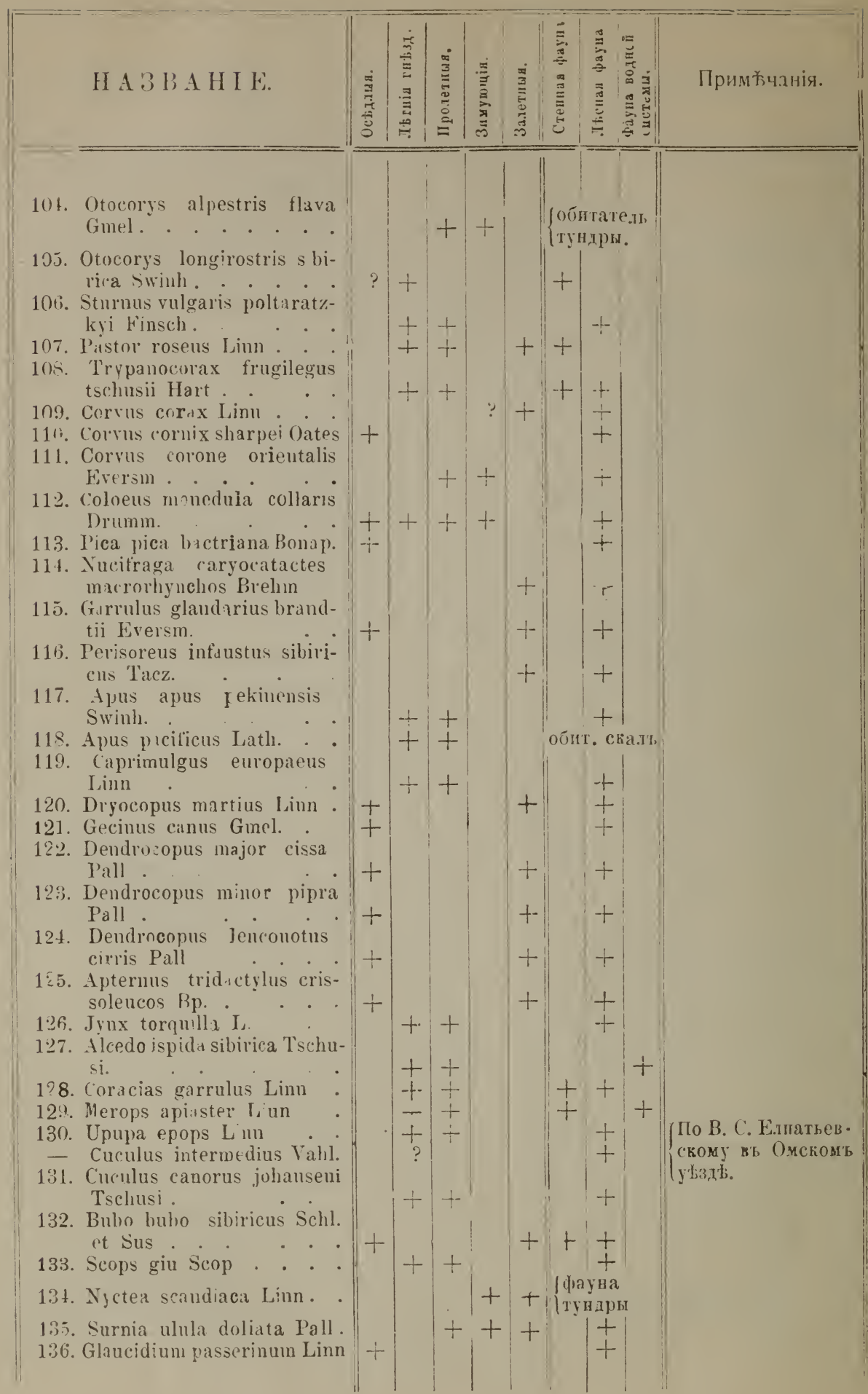




\begin{tabular}{|c|c|c|c|c|c|c|c|c|c|}
\hline HA 3 B A H I E. & $\mid$ & 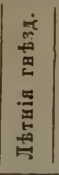 & 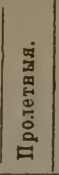 & 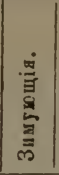 & 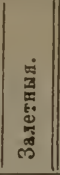 & 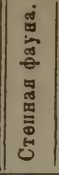 & 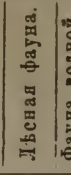 & 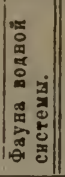 & Примъчанія, \\
\hline 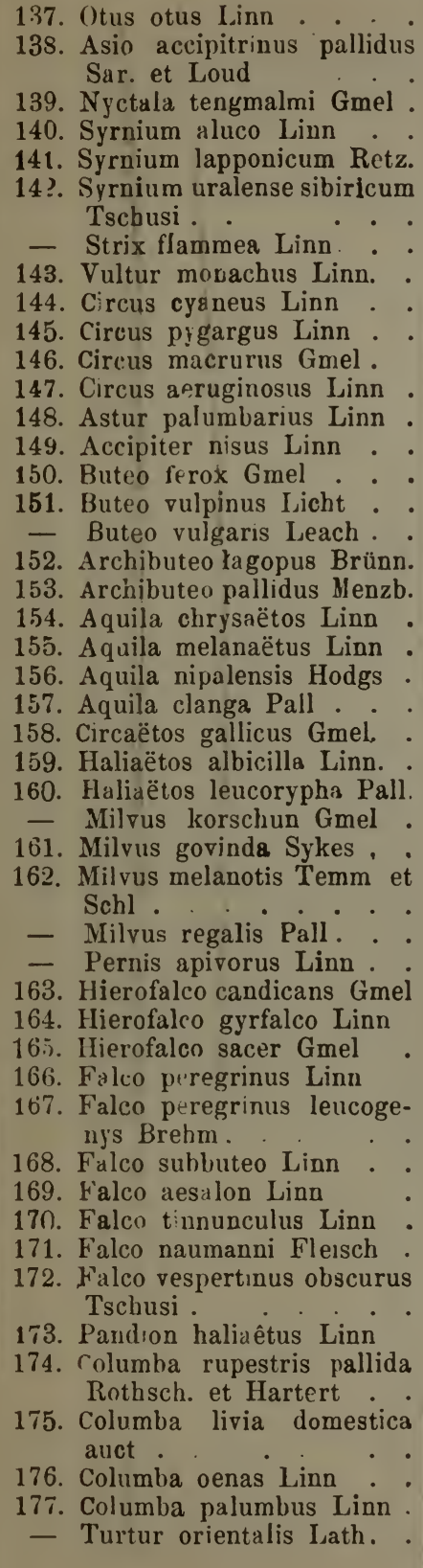 & $\begin{array}{c}+ \\
+ \\
?\end{array}$ & $\begin{array}{l}+ \\
+ \\
+ \\
+ \\
+ \\
+ \\
+ \\
+ \\
+ \\
+\end{array}$ & $\begin{array}{l}+ \\
+ \\
+ \\
+ \\
+ \\
+ \\
+ \\
+ \\
+ \\
+\end{array}$ & $\begin{array}{c}+ \\
+ \\
+ \\
?\end{array}$ & $\begin{array}{c}+ \\
+ \\
? \\
+ \\
+\end{array}$ & $\begin{array}{l}+ \\
+ \\
+ \\
+ \\
+\end{array}$ & $\begin{array}{l}+\mid \\
+\mid \\
\text { итате } \\
+1 . \\
+ \\
+ \\
+ \\
+ \\
+ \\
+ \\
+\end{array}$ & $\begin{array}{l}+ \\
+ \text { eли } \\
\text { c'sв. } \\
+\end{array}$ & $\begin{array}{l}\left\{\begin{array}{l}\text { По проф. М. А. } \\
\text { Мензбиру. }\end{array}\right. \\
\text { По В. Плотнвову. } \\
\text { По В. Пхотникову. } \\
\left\{\begin{array}{l}\text { По Finsch'у и Мо- } \\
\text { розову. }\end{array}\right. \\
\text { По Словцову. } \\
\text { По Словцову. }\end{array}$ \\
\hline
\end{tabular}




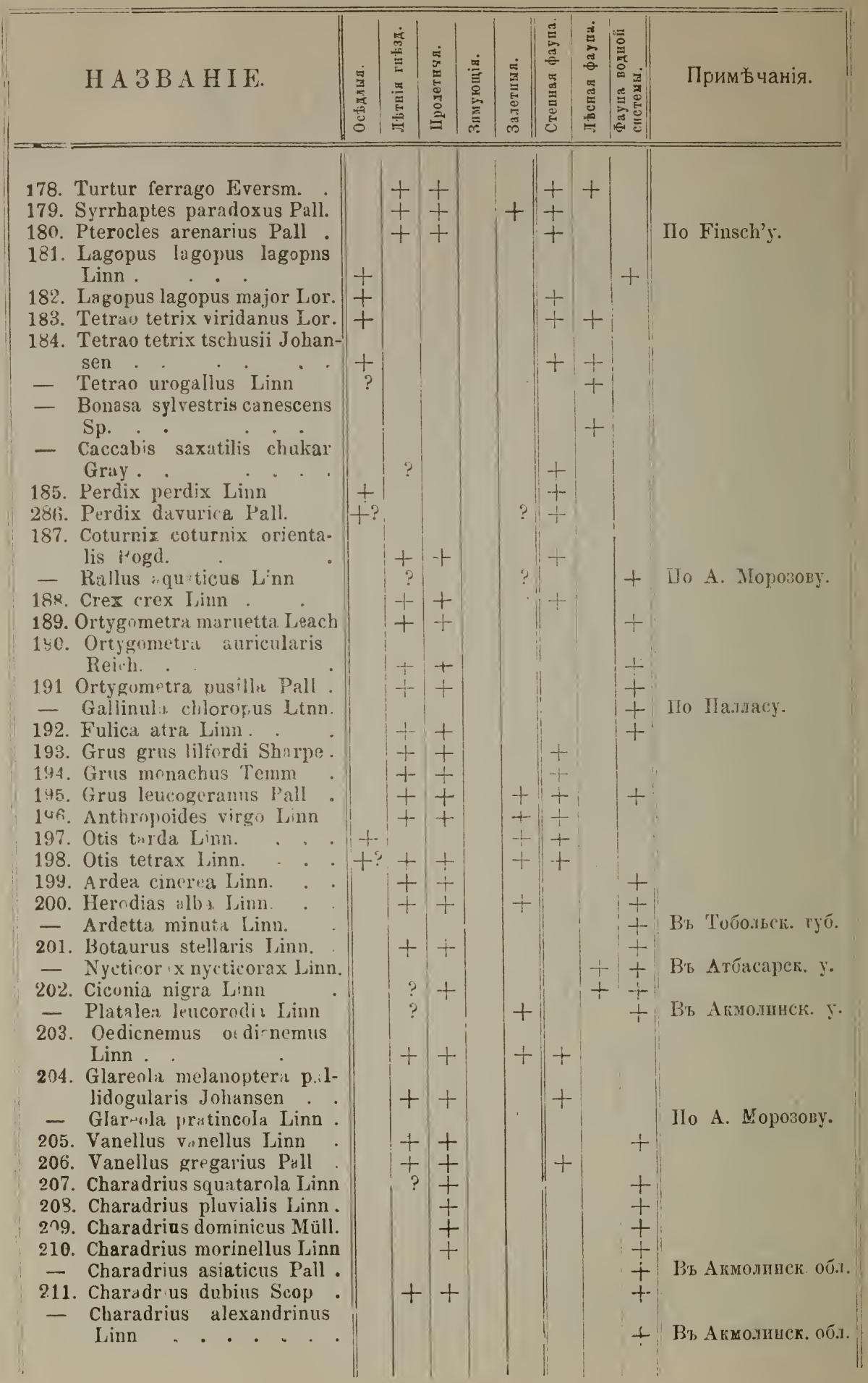




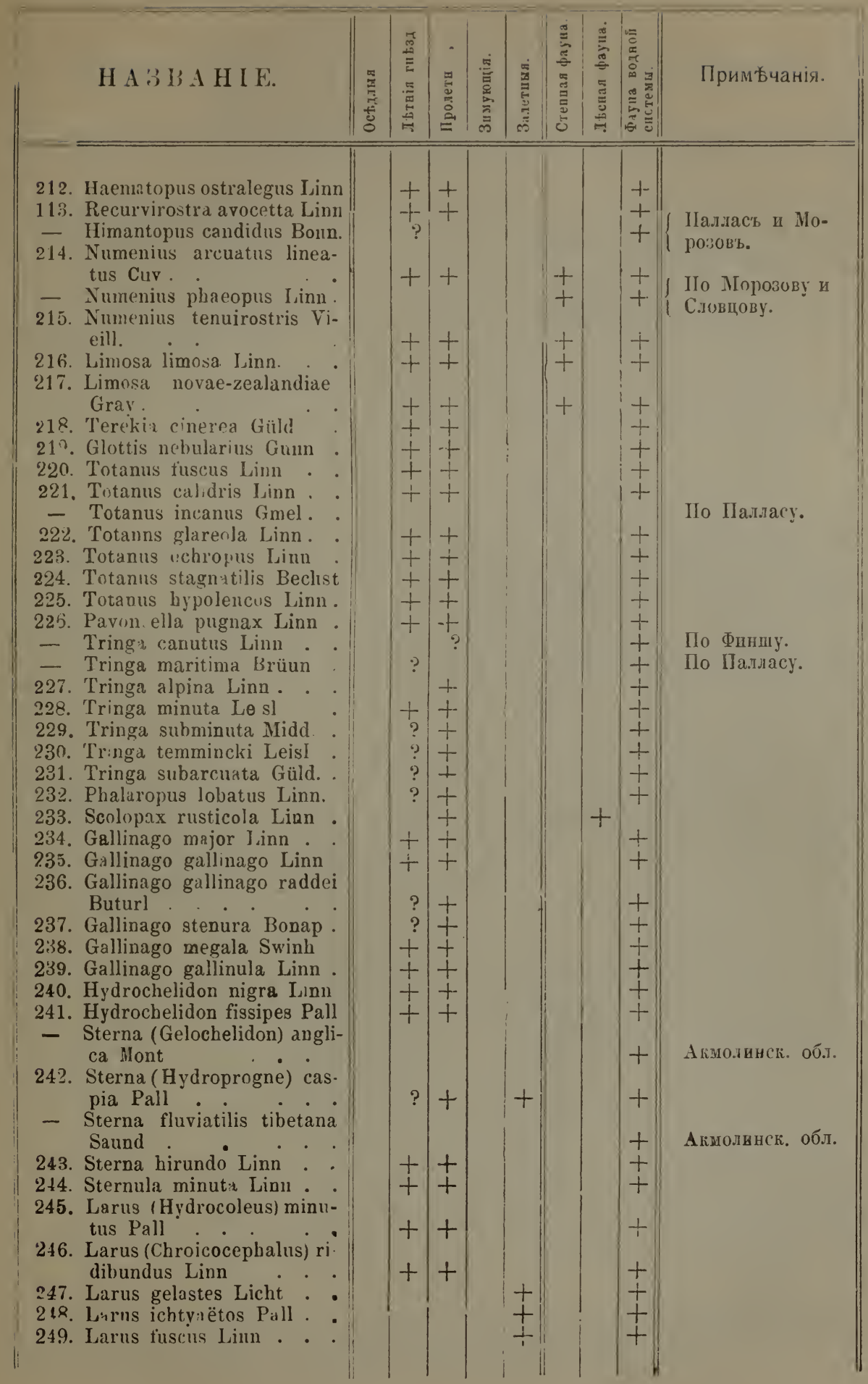




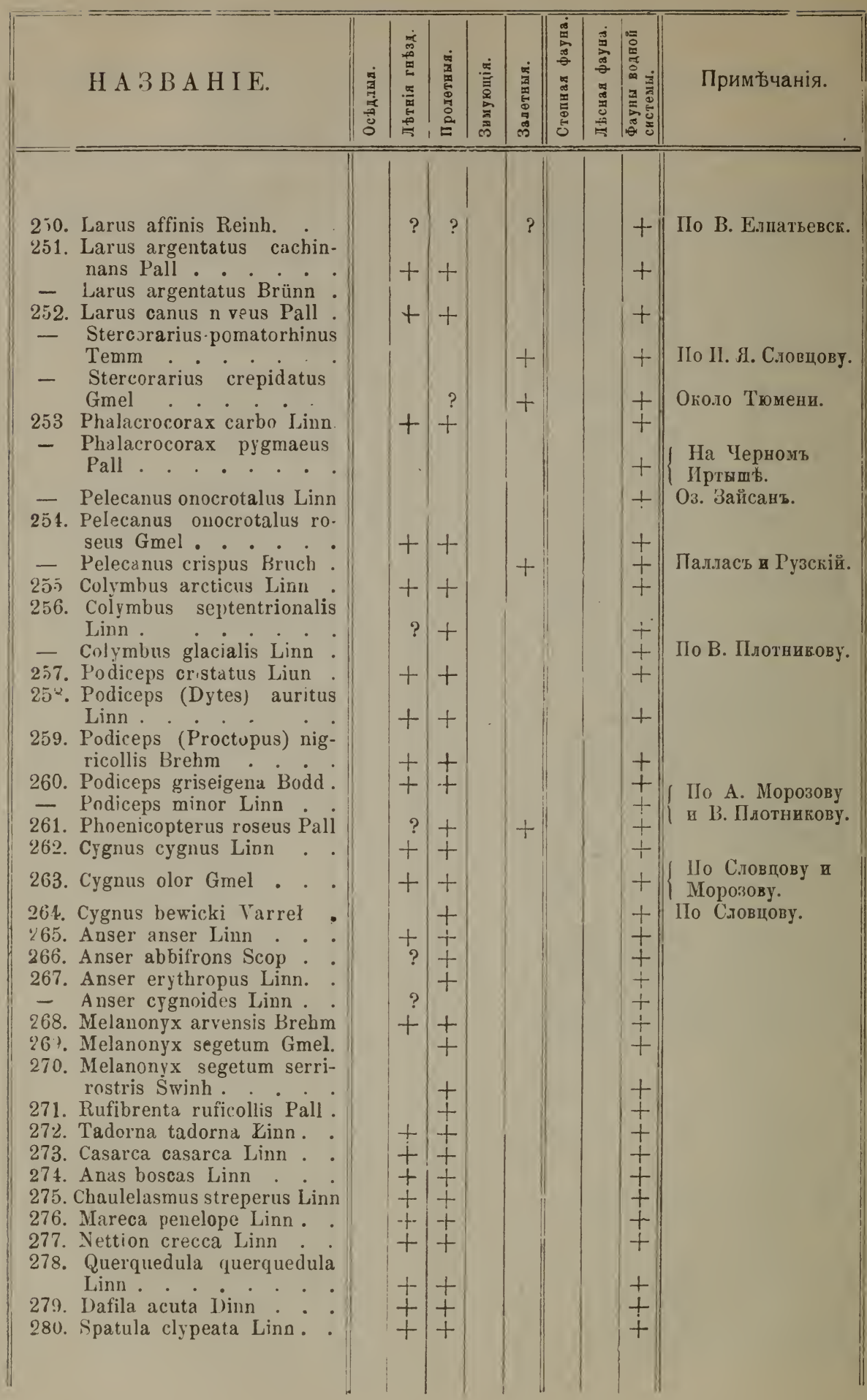




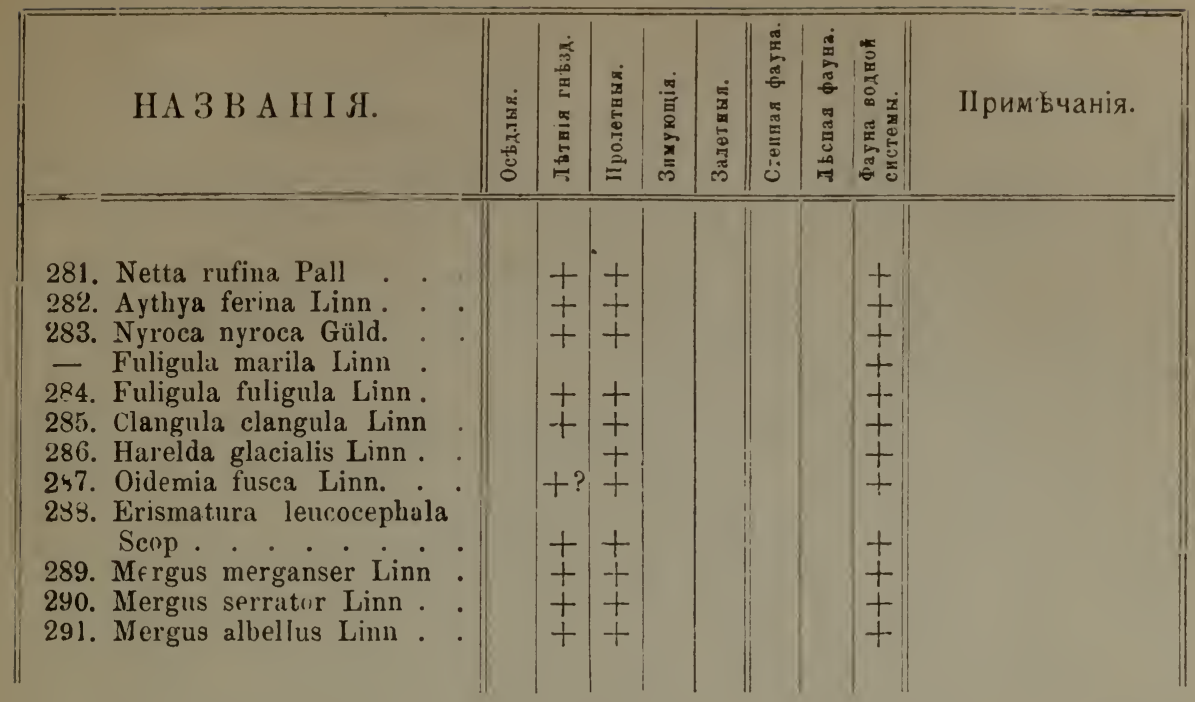

Для болье удобнаго оріентированія относительно географическаго положенія тьхъ мъстъ Томскаго края, въ окрестностяхъ которыхъ. производились орнитологическіе сборы, послужившіе матеріаломъ для этой работы, помъщаю таблицу, составленную частью по карть Омскаго военнаго округа, частью по работь IO. A. ІІІмидmа*).

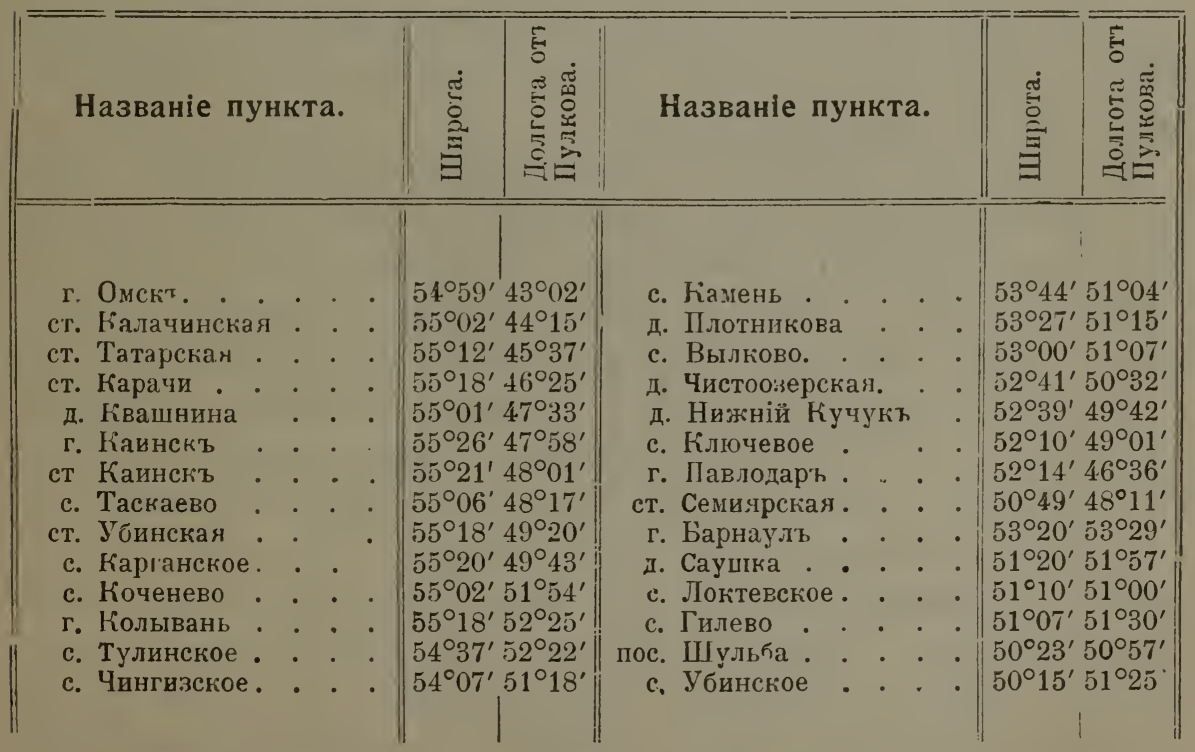

*) Список' астрономическпхъ опредъленій геограуическихъ коордннатъ пунктовъ, исполненныхъ въ Сибири и Степномъ Г'енералъ-Губернаторствъ съ 1893 по 1898 годъ. (Записки Западно-Спбирск. Отд. Имп. Русск. Геогр. Общ. книжка XXIV)). 
Что касается измьреній шкурокъ и мумій, которыя помьщены въ спеціальной части работы, то считаю не лишнимъ указать на нъкоторыя особенности пользованія изљрительными приборами. Для каждаго экземпляра нашнхъ коллекций я старался получить четыре цифры, обозначенныя буювами r, a, с и $t$. При этомь

1) $\mathrm{r}$ (rostrum-длина клюва) означаетъ длину прямой линіи отъ начала лобнаго оперенія до гонца верхней половины клюва, измьряемой цирнулемь въ $\mathrm{mm}$.

2) a (ala-длина крыла) равняется длинь сложеннаго крыла отъ кистевого сгиба до конца самаго длиннаго изъ маховыхъ въ $\mathrm{mm}$. Крыло при измъреніи ньсколько придавпивалась къ линейкь или столу. Линейкою при измђреніи длқны крыла мелкихъ птицъ (съ ғрыльями менье $16 \mathrm{ctm}$. длиною) служиль приборъ для измғренія разменовъ яицъ, весьма удобный въ томъ отношеніи, что кистевой сгибт крыла пожеть быть придавленъ къ неподвижной стойкь прибора. При измьреніп болье крупшыхъ птицъ я пользовался лентой или линейкой.

3) с (саиdа-длина хвоста) означаеть разстояніе, измьряемое циркулемъ въ mm.. стъ того мъста, гдь среднія рулевыя выходятъ изъ кожи или отъ легко процупываемой кобчиковой кости до конца самаго длиннаго изъ рулевыхъ.

4) $\mathrm{t}$ (tarsus-длина плюсны) измьряется циркуленъ отъ впадинц на пяточномъ суставь сзади до нижняго края посльдннго щитка плюсны спереди (въ $\mathrm{mm}$ ).

Не могу не подълиться впечатльніемъ, вмнесеннымъ мною при произведенныхъ мною измьреніяхъ: какъ э ни старался произвести тщательно изићренія, результаты при повторномъ измьренли одной и той же пкурки нерьдко получались различные, а потому являются для меня сомнительными настолько, что я не разъ совершенно хотьбл оставить изиренія и весьма сомнъваюсь въ точности полученныхъ цифрь преимущественно для крупныхъ птиц. Но сопоставляя всь результаты измьреній и могущія возникнуть при этомъ ошибки, я полагаю, что изъ табличекъ измьреній получается въ обшемъ всетаки приблизительно върная картина размђровъ птицы, а при экземплярахъ разнаго возраста можетъ составиться представленіе объ относительной величинь и быстроть прироста измъряемыхъ органовъ. Такого рода соображенія побудили меня довести работу измбреній до конца.

Измьренія длины и ширины яицъ въ $\mathrm{mm}$, въсъ пустыхт скорлупъ въ gr. 


\section{Часть спеціальная.}





\section{OSCINES (Воробьиныя).}

\section{Turdus (Geocichla) varius Pall. Дроздъ пестрый.}

Пестрый дроздъ по И. Я. С ло в цо в у (стр. 260) ,весьма рьдко посъщаетъ самые южные предълы Тобольской губерніи“. Въ большемъ количеств ь найденъ С ло в ц о ы м ъ въ Акмолинской обл., близъ Кутуркульской станціи и убить около Омска въ конц б сентября 1878 года. А. П. В ели жани н передавалъ мнъ, что имъ былъ уб́ить 10 августа 1992 или 1893 г. одинъ экз. около Барнаула. Въ степной части Томской губерніи этотъ красивый дроздъ намъ ни разу не попадался. Въ окрестностяхъ Томска добыть нъсколько разъ.

\section{Turdus (Geocichla) sibiricus Pall. Дроздъ спборскій.}

Сибирскій дроздъ, свойственный Восточной Сибири, пока не добытъ вт степной части нашего края. У Бр анд т а (стр. 442 nomen nudum!) есть указаніе на нахожденіе этого вица въ Западной Сибири. Затьмъ А. М о ро зо в ъ (стр. 11) сообщаетъ, что этотъ дроздъ ,разъ былъ встрьченъ подъ Омскомъ“.

\section{Turdus viscivorus Limn. Дроздт-деряба.}

Такъ какъ въ коллекціяхъ изъ степной части нащего края экземпляровъ дерябы н'бтъ, то нельзя рбшить вопроса о принадлежіости къ подвиду hodgsoni Hum. Во время нащихь пољздокъ намъ этотъ дроздъ не попадался, но онъ приводится И. Я. С ло в ц в ым 'ь (стр. 259) какъ обыкновенная птица въ Курганскомъ и Ялуторовскомъ, рбже въ Тюменскомъ убзд. Кромъ того найденъ Словцовым и и въ Кокчетавскихъ горахъ (стр. 143). М. Д. Р у з ск ій (стр. 17 и 19) нашель дерябу какъ въ березовыхъ рощахъ юга Тобольской губ., такъ и въ сосновомъ бору на берегу Иртыша въ Тюкалинскомъ уъздъ. 


\section{Turdus iliacus Linn. Дровдь бжлобровый.}

Дроздъ бълобровый, часто встрьчающійся въ качествђ гнђздящейся птицы в'ь окр. Томска, въ степной части нашего грая рбдокъ. Изъ степей въ нашихъ коллекціяхъ экземпляровъ ньтъ. F in s ch (стр. 183) видьль въ коллекціи С ло в Iц о в а экз. изъ окрестностей Ояска. По Сло вцо в у (стр. 259) этоть дроздъ около Омска убить на пролеть въ конц' марта, около Кургана 10-го апрьля. По П.А. М о р о з о в у (стр. 12) „точныхъ данныхъ о существовании этого дрозда нбтъ“. М. Д. Р у з с к і й въ южной полось⿱ Тобольской губ́ также не находиль этого дрозда.

\section{э. Turdus musicus Linn. Дроздъ пьвчій.}

Пьвчій дроздъ гнъздится въ Кулундинскомъ бору у села Вылкова. Птицы намъ здьсь не попадались, но мой спутникъ И. Н. Ки и и лло в ъ нішель на березъ гнъздо этого дрозда и принесъ мн'ь его для опредъленія. По литературнымъ даннымъ пћвчій дроздъ встрбчается въ Барабинской степи. У П ал л а с а (стп. 455) приводится названіе этого дрозда, употребляемое „барабинскими татарами“ (,,barbijok"). Fin s ch (стр. 183) получиль итъ Сл о ц о в а экземп. изъ окр. Омска. По С ло в цо в у (стр. 259) пъвчій дроздъ чаще встрбчается въ южной части Тюменскаго округа по сосновым лћсамъ долины Пышмы, чьым въ сьверной. М. Д.. Р у з с к ій (стр. 17) нашелъ его въ березовыхь рошахъ южной полосы Тобопьской губ. По А. М о р о зо в у (стр. 12) это „обычный видъ подъ Омскомъ“.

\section{Turdus pilaris Limn. Дроздт рабининъ.}

Во время нашихъ пољздокъ по степям нашего края дрозды намъ попадались вообше довольно рtдкю. Въ особенности меня поразило отсутствіе дроздовъ въ т. н. „рямъ“ близъ ст. Убинской (Каинскаго у.), гд官 всъ условія благопріятствовали ихъ тамъ сушествованію. Въ березовыхъ ,колкахъ“ близъ названной станціи мы ихъ однако нашли. Въ окрестностяхъ станціи Каинскъ изъ дроздовъ П. А. Ш а с т о в с к і й находилъ только рябинниковъ. Въ Кулундинской степи преобладающимъ видомъ изъ дроздовъ является повидимому, тоже рябинникъ. Во время стоянки парохода у с. Чингисъ (Барнаульскаге убзда), въ кустахъ около 
пристани я на небольшемь разстояніи мог'ь рәзглядъть нбсколько рябинниювъ. Эти же дрозды попадались намъ бмизъ деревни Плотниковой, с. Вылкова и др. Въ окр с. 'Јулинскаго на Оби этотъ дроздъ нерьдокъ. Въ приалтайскихт, спепяхъ найденъ проф). H. Ө. К а щ е н к о (с. Локоть). По литературнымъ даннымъ, въ степяхт, Западной Сибири рябинникъ „,амый обыкновенный видъ дроздов'ь едвали не во всей Тобольской губерніи“" (С л о вц о в ъ стр. 259). встрьчается ,чаще въ Тобольской губ., чъъм въ Акмолинской области, (рябина очень рьдка)“ (А. М о р о з о в ъ стр. 12). Рябинникъ по В. Н. ІІ л о т н и ко в у (стр. 9) встрбчается по Иртышу, „гд⿱ есть ягодникъ, особ́енно объъдаются крушиной“. М. Д. Р у з с к і й (стр. 17 и 19) нашелъ рябинниковъ, какъ въ березовыхъ рощахъ, такъ и въ сосновыхъ борахъ юга Тобольской губерніи.

Экземпляры юоллекцій:

1) t ad. дер. Плотникова. 14 VI 02 r. 19 a. 142 c. 107 t. 34 шк.

2) sex.? juv. с. Вылково 17 VI $02 \quad 15 \quad 122 \quad 83 \quad 33$ мум.

\section{\%. Merula (Turdus) atrigularis Temm. Tpoздь черно- зобыи.}

По свидбтельству И. Я. Словцова (стр. 259) чернозобый дроздъ „встрбчается въ теченіи всего льта въ пихтовыхъ льсахъ Тюменскаго и Туринскаго округовъ “. На пролеть въ посльднихъ числахъ апрьвя и въ началь мая его убивали по Словцову и около Омска. Въ южной полось Тобольской губерніи М. Д. Р у з скі й его не находилъ. По А. Морозову (стр. 12) онъ подъ Омскомъ встрьчается тоже лишь на пролеть. По свидьтельству Finsch'a (стр185) д-ръ А. Брэм ъ добыль 1-го мая 1876 г. (по нов. стил.) экземпляръ этого вида близъ Семипалатинска. Намъ въ степяхъ нашего края этотъ дроздъ не попадался. Даю измъренія одного экзелпляра моей частной коллекціи изъ окр. г. Барнаула.

1) ad 8. IV. 1899. r. 20. а. 130. с. 94. t. 33 шк.

П. А. Ш а стовскі й доставилъ мнъ экземпляръ изъ окрестностей ст. Каинскъ, добытый въ 1906 г. Его изиьренія:

2) ad. 9 V. 1906 . r. 18,5 . a. 129,5 c. 89 . t. 33 . шк.

\section{Merula nerula Linn. Дрозды черный.}

Въ коллекціи И. Я. С ло вцо в а изъ окрестн. гор. Омска О. F in s ch (стр. 186) видълъ этотъ видъ. Но самъ И. Я. С л о в ц о в ъ 
не упоминаетъ о немъ вовсе. Остается невыясненной и возможная принадлежность экземпляра къ M. m. maxima Seeb.

\section{Cinclus melanogaster Brehm. Чернобрюхая оляпка.}

По сообщенію П. А. Ша сто в скаго имъ убита 8-го іюля 1902 г. на озерь близъ станціи Карачи (Барабинская степь) оляпка съ темнымъ брюхомъ. Думаю, что это спобщеніе относится къ названному виду. Свъдъній о нахожденіи оляпокъ въ степной части нашего края не имъется, если не считать ниже приведенное „,nomen nudum“А. Мор о з в а. Чернобрюхая оляпка доставлена А. М. Ни кольскому (стр 194) ихъ Усть-Каменогорска и Алтайской станицы.

$\mathrm{B}_{\mathbf{b}}$ нашихъ коллекціяхъ экземпляровъ изъ степной части Томскаго края не имъется.

\section{? Cinclus aquaticus Brehm. Оляпка, водыной воробей.}

Nomen nudum A. Mорозов т (стр. 12).

\section{Ruticilla phoenicurus Linn. Fopnxвостfa.}

Горихвостка мъстами несомнбнно гнбздится въ степной части нашего края. Вт Кулундинской степи мы нашли ее очень обыкновенной в’ъ бору близъ с Вылкова (16-22. VI. 02.). Несомнънно гнъздится и въ с. Тулинскомъ на Оби и подъ Барнауломъ. F ins ch (стр. 161) получиль отъ С ловцова изъ Омска ничъмъ не отличающіеся отъ западно-европейскихъ. По мнбнію С ло в ц о в а, переданнаго Фин ше м ъ, горихвостка подъ Омскомъ не гнбздится. Но самъ И. Я. Словцов ъ (стр. 258) находилъ эту птичку во всъхъ округахъ Тобольской губерніи, кромъ Березовскаго и Обдорскаго, а затьмъ сообщаетъ, чго она водится около Омска, по Горькой линіи и по всему Кок'етавскому убзду (стр. 141). М. Д. Р узским ъ (стр. 17) онъ найдена въ березовыхъ рощахъ Тобольской губ. Наконецъ, А. Морозо в ъ (стр. 12) приводитъ ее для всего съвера Акмолинской области и Тюкалинскаго окр.

Экземпляры коллекцій;

1) ᄒ аd. с. Вылково 17/ І 02 r. 11,5 а. 79 с. 61 t. 21.

2) ㅇ ad.

3) tad.

4) $t \mathrm{ad}$.

10

5) баd с.Тулинское $17 / \mathrm{V}$

76

$81 \quad 59,5$

$80 \quad 60$

$81 \quad 59$
19.

21.

21.

\footnotetext{
21.
} 


\section{Ruticilla tithys Scop. Topmxвocrka-чернушна.}

У одного только Fin s c h'a (стр. 162) замбтка о томъ, что онь видълъ экз. изъ окр. Оиска въ коллекціи И. Я. С ловцова Другихъ указаній нбтъ, какъ нбтъ и экземпляров'ь въ коллекціяхъ. Эта горихвостка могла только случайно залетьть въ Омскъ.

\section{Pratincola maura Pall. Aвiatcкій черносоливый relaнb.}

Этотъ чеканчикъ одна изъ обыкновеннъйшихъ птичегъ степной части нашего края. Добытъ въ значительномъ числь экземпляровъ всьми коллекторами, работавшими въ нашихъ степяхъ. Литературныхъ указаній много, причемъ нъкоторыми авторами приводится не подъ надлежащими названіями (А. М ор озов ъ (стр. 12) P. rubicola Bechst; И. Я. С ловцовъ (стр 258) Р. indica Blyth.). Чеканчикъ этотъ предпочитаетъ открытыя, лишенныя древесной и кустарной растительности, мъстности.

Экземпляры университетскихъ коллекцій:

1) ᄒ ad. ст. Уб̆инская 8/VI 99 r. 10 a. 67 c. 48 t. 21 шк.

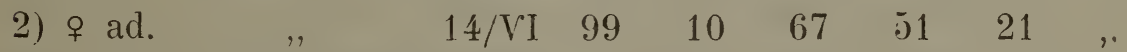

3) б ad. ст. Татарская 16/VI $99 \quad 11 \quad 67 \quad 48 \quad 21$,"

4) 우 ad. $" 15 / \mathrm{VI} \quad 99 \quad 11,564 \quad 4.5 \quad 20,5$,

5; ᄒ с. Убоинское 27/VI $00 \quad 11 \quad 67 \quad 51,521 \%$

6) $\delta$ д. Саушка 2/VI 00 ? $7: 168$ 49,5 20,5 ,

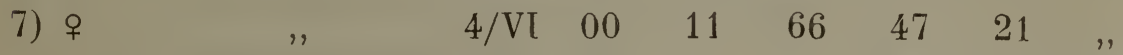

8) t ad. с. Вылково 18/VI $02 \quad 9,7 \quad 66 \quad 49 \quad 20$ мум.

$\begin{array}{llllllll}9) & \text { ad. } \quad, \quad 21 / \mathrm{VI} & 02 & 10 & 68,5 & 48 & 20,5 & \text {, }\end{array}$

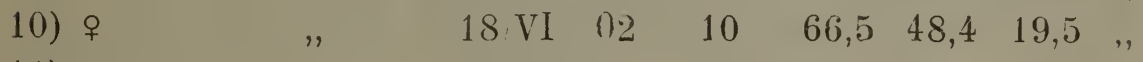

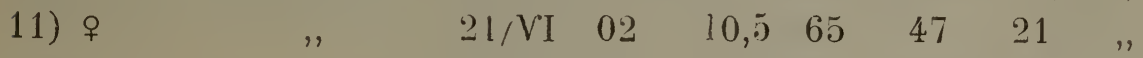

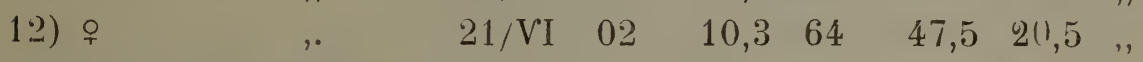

13) 요 д. Нижн. Кучуюъ $5 /$ VII $02 \quad 10,5 \quad 66 \quad 48 \quad 20,4$.,

14; sex?juv. с. Ключевое 9, VII $02 \quad 9,5 \quad 67 \quad 49 \quad 20,3$,"

151 sex?juv. " $\quad$ 10/VII $02 \quad 9,5 \quad 67 \quad 51 \quad 20,5 \quad$,

16) sex? ст. Семиярская 20/VII $02 \quad 10 \quad 70 \quad 53$ 2 1,5 ,

17) sex? " 20/VII $02 \quad 10 \quad 67 \quad 51 \quad 21,5$,

Экземпляры частної коллекціи:

18) ᄒ ad. окр. г. Барнаула 19.VI $98 \quad 11 \quad 66 \quad 48 \quad 21,5$ шк.

19)

10/VIII $98 \quad 10 \quad 66 \quad 49,5 \quad 19 \quad$," 
20) sex?juv окр. г. Барн. 10. VIII $98 \quad 9,5 \quad 63 \quad 48 \quad 21$ шк.

21) ad. ст. Каинскт

22) 우 ad.

$14 / \mathrm{V}^{\mathrm{N}} \quad 04$

10

67

47

20

23) ᄒ ad.

$14 / \mathrm{V} \quad 04$

9

65

45

$2 \cdot 2$

$16 / \mathrm{V} \quad 04$

$67 \quad 45$

22

\section{Pratincola rubetra margaretae Johansen. Cиоирскій луговой ченант.}

Недостаточно выясненной въ Западной Сибири является область распространенія лугового чекана, въ особенности восточная граница этой области не прослґжена. Чеканъ этотъ вообще не считается принадлежашим къ авифаунь Западной Сиблир, въроятно всльдсвіе категорическихь словь П. С. П а лл а с а (стр. 467) , in Sibiria nunquam observata“. Проф. М. А. М ен з б ир в (стр. 1018), касаясь вопроса о восточной границћ области гнъздовья, сообщаетъ, что әтотъ чеганчикъ уже въ Тобольской губ. не вайденъ, а между тьэ O. Fin s ch (стр. 165) сообщиль уже въ 1879 г., что видъ̌лъ в’ъ коллекціи С ло в ц о в а экземп. изъ окрестностей Омска. Посль̆днее подтверждается самимъ С л о в ц ов ы з (Путев. записки стр. 142), а равнымъ обрязомъ и указаніемъ А. Морозова (стр. 12), что нашъ чекань встрбчается .,подъ Омскомъ нерьдко '. Наконецъ, экспедиція П. Г. Иг н а т о в а нашла эту птичку въ 30 верст. къ югу оть Омска, причемъ В. Л. Б і ан к и (стр. 6) ститаеть ея опереніе нормальнымъ. Н о m е у е $\mathrm{r}$ и Т а $11 \mathrm{cr}$ ѐ (стр. 85) получили отъ своихъ коллекторовъ 2 экзем пляра изъ Сибири, но къ сожальнію, мьстонахожденія не упомянуты. Проф. Н. Ө. К ащ ен ко (стр." 79) в’ мађ 1898 г. трижды наблюдалъ этого чеканчика между Барнаулом'ъ и с. Смоленскимъ по почтовому тракту, ведущему чрезъ Бійскъ, но экземпляры не были добыты этой экспедиціею.

Въ окрестностяхъ Томска эта птичка тоже встрђчается и первый экземпляръ, добытый здъ̌сь 1-го мая 1903 г. (‡ ad.) П. А. Ш а с тов с ки м ъ на столько отличается отъ западно-европейскихъ и съверо-европейскихъ экземпляровъ, имбющихся въ моей коллекціи и присланныхъ мнб на время для сравненія, что я рбшиль выдълить западно-сибирскую форму какъ новый подвидъ подъ названіемъ P. r. margaretae. Отличительные признаки, отмъченные мною при сравненіи б изъ разныхъ мъстностей, подтверждагтся и при сравненіи 우. Первую + этой формы я полу- 
чилъ изъ окрестностей Томска 2-го мая 1904 г. Новая форма отличается отъ типовой болье короткимъ клювомъ, болъе бльдной окраской верхней и нижней сторонт, болье грубой пятнистостью верхней стороны и былой оюраскою концовъ крайнихъ рулевыхъ на внутреннихъ опахалахъ. Первие описаніе появилось въ Ornith. Jahrb. 1903. стр. 232.

В7, степной части Томскаго края во время нащихъ побздокт луговой чеканъ не найденъ.

Измренія томскихъ экземпляровъ;

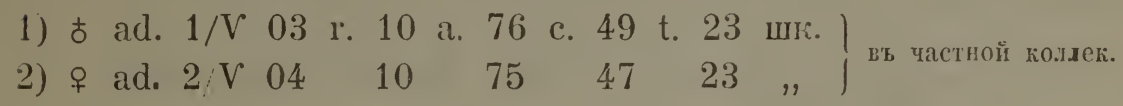

\section{Saxicola lencomela Pall. Yenantu-Iu'buanica.}

$$
\text { (=S. morio Ehrbg.) }
$$

Экспедиція проф. Н. Ө. К а щ е н ко 1900 г. собрала четыре экз. этсго вида въ дер. Саушкъ. Въ Барабинской степи этотъ чеканъ не найденъ. Въ Кулундинской степи мой спутникъ $Г$. А. Н е в е д р о в ъ убил'ь самку чекана-пльшанки въ соснивомъ бору, называемомъ Съвернымъ, близъ с. Ключевого 9-го іюля 1902 года. Нахожденіе этого вида въ степной мъстности, довольно ровной, переськаемой сосновыми борами и лишенной возвышенностей, представляетъ нъкоторый интерест. Несмотря на поиски за другими экземплярами, добытый пстался единственнымъ.

Экземпляры коллекцій:

1) semiad д. Caywia 2/VI 00 r. 12 a. 92 c. 65,5 t. 23 шк.

2) $t$ ad.

$2 / \mathrm{VI} 00$

$13 \quad 89$

63

$22 "$

3) $q \mathrm{ad}$.

$2 / \mathrm{Vl} 00$

? $\quad 89-90 \quad 59$

$21,5 \quad$,

4) $q$ ad.

$4 / \mathrm{Vl} 00$

$\begin{array}{lll}13 & 88 & 62\end{array}$

22,

5) + ad.

с. Ключевое

$9 / \mathrm{VII} 02$

$12,5 \quad 84 \quad 53,5$

22 мум.

Опереніе добытой въ Кулундинской степи пльшанки довольно изношенное. По распредълепію чернаго и бълаго цвътовъ на рулевыхъ этотъ экземпляръ почти тождественъ сь алтайскими экземп. и нъсколько отличается отъ экз. изъ Закаспійскаго края полученнаго мною отъ М. Ге р м с а.

Что каснется литературныхъ данныхъ о нахожденіи этого вида въ интересующей насъ мъстности, то уже П, С. П ал лас ъ 
(стр. 479) указываеть на нахожденіе пльшанки ,.сігса Altaïcos montes". Въ Кокчетавскомъ уъзды она найдена С л о в ц о в ы м ъ (стр. 142) на скалистыхъ сопкахъ и такъ же, какъ и нами ,,въ сосновомъ льсу“. Въ, степяхъ южной полосы Тобольской губ. пльшанка найдена М. Д. Р у з с к и м ъ (стр. 14) на склонахъ праваго берега Ирэыша. Она же добыта экспедиціею П. Г. И г н а т о в а (стр. 7 В. Б і а н ли) въ одномъ экземп. въ 150 в. къ сьверовост. отъ Акмолинска. Нахожденіе пльшанки въ Кулундинской степи связываетъ такимъ образомъ облласть ея гнбздовья на Алтаб съ таковой въ степяхъ Тобольской губ. и Акмолинской области.

\section{Saxicola oenanthe Linn. Чeкaн'b-layemia.}

Чеканъ-каменка въ Барабинской степи вдоль линіи желъзной дороги всюду очень обыкновенная, гнъздящаяся птица. 13-го іюня 1899 г. молодые чеканы уже летали. Мћстами находили этихъ птичекъ въ совершенно болотистыхъ мҺ̌стностяхъ. Я увъренъ, что съ проведеніемъ жельзной цороги этотъ чеканъ, водящійся близъ обрывовъ, канавъ по глинистымъ и каменистымъ мъстамъ, появился во многихъ мұстахъ, гдъ его раньше небыло. Теперь они обычное явленіе повсюду, около полотна дороги. Очень часто сидятъ на вагонахъ, откуда раскланиваются передъ проходящими. Гнбзда ихъ, помбщаются по наблюденіямъ П. А ІШ а сто в скаго въ землъ, въ норкахъ. Размъры и въсъ 5 яицъ кладки, взятой ий 15-го мая 1905 г. близъ ст. Каинскъ сльдующіе:

$$
\begin{aligned}
& \text { 1) } \frac{19,5 \times 15,0 \text { мм. }}{0,13 \text { гр. }} \text { 2) } \frac{19,5 \times 15,3 \text { мм. }}{0,14 \text { гр. }} \text { 3) } \frac{18,8 \times 15,0 \text { мм. }}{0,13 \text { гр. }} \\
& \text { 4.) } \begin{array}{c}
18,8 \times 15,0 \text { мм. и б) } \\
0,13 \text { гр. } \\
0,14 \times 15,0 \text { гр. }
\end{array}
\end{aligned}
$$

Какъ ни странно, но столь обыкпвенный въ другихъ частяхъ нашего края чеканъ-каменка во время поъздки въ lіулундинскую степь намъ сталъ попадаться лишь за предћлами Томской губ., въ Павлодарскомъ убздъ близъ озера Маралда и въ окрестн. ст. Семиярскпй, а на всемъ протяженіи нашего пути отъ с. Камень до западныхъ предъловъ губерніи ни разу не былъ замбченъ.

Экземпляры коллекціи:
1) б аd. ст. Убинская
8/VI 99 r. 14 a. 100
c. 61 t. 29 шк.
2) ј јur.
13/VI $99 \quad 11$
85
$27, \overline{5}$ 


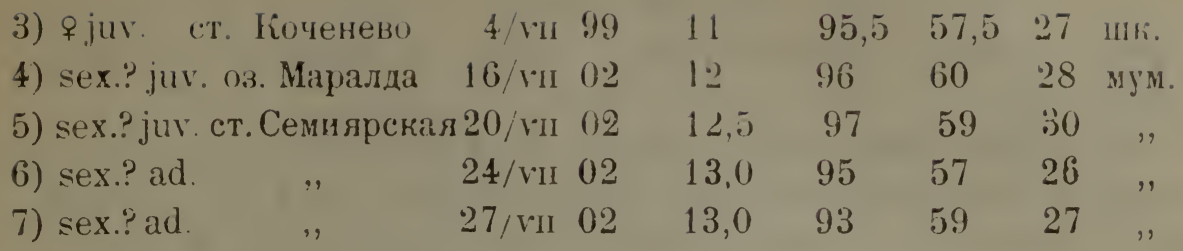

Отъ экземпляровъ западно-европейскаго происхожденія сибир скіе чеканы ничьмъ существеннымъ, повидимому, не отличаются. Первый экземпляръ нашей коллекціи замъчателенъ въ томъ отношеніи, что между бълыми перьяии надхвостья и сырыми спины у него полоса коричневаго цвьта шириною вт 12 мм. Что касается литературныхъ данныхъ, у всбхъ разсматриваемыхъ здьсь авторовъ имьются указанія на нахожденіе әтюго вида, лишь И. Я. Слов пов т, (Іут. записки, стр. 142) отмтчаетъ его отсутствіе въ

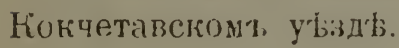

\section{Saxicola isabellina Riipp. Yetan'-Hacymb.}

Проф. Н. Ө. Кащ ен ко (Результаты, стр. 81) на половинь пути вежду Бійскомъ и Барнаулоп „,случайно отбившійся экземпляръ“" этого вида. По В. С. Елпатье в скому (стр. 152) гныздится въ Ожскомъ уьзды. Иныхъ указаній на нахиждепіе этого чекана въ степной части нашего края въ литературђ нытъ. Ньтъ и экземпляровъ въ коллекціяхъ.

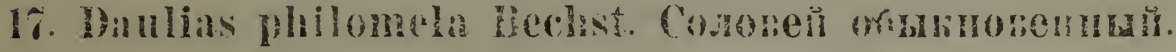

Пьніе этого силовия мы слышали 9-го іюпя 1902 г. во время стоянки парохода на Оо́и у Усть-Чаусской пристани Во время пођздки чо Барабинской степи въ 1899 г. миь не приходилось слышать его пъніе въ окрестностяхъ ст. Убинской, хотя періодъ пьнія его еще не пконился. Во время пођздки по Кулундинской степи соловей также не быль замћченъ. Экспедиція проф. Н. $Ө$. Ка це н к 1900 г. добыла цва экземиляра въ сель Локоть. Въ моей чачтной коллекціи имьетея әкземляръ изь Барнаула.

Измтренія:

1) $q$ ad. г. Барнауль 18 vi 98 r. 12 a. 85 c. 69,5 t. 25,5 шк.

3) $\delta$ ad. c. Локоть 15 ri $00 \quad 14 \quad 91 \quad 71,5 \quad 26 \quad$,

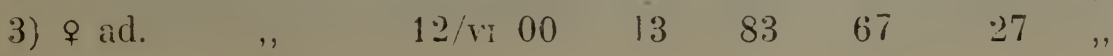


На горль самца бъловатый цвђт’ь больше распристраненъ, чьмъ у самокъ. Рыжая окраска хвоста у самца гораздо ярче, чธัณ

Въ конц' мая 1834 г. Н. v $\mathrm{Helmersen} \mathrm{(cтp.} \mathrm{18)} \mathrm{*)}$ слышалъ пъніе соловья близъ Берска на Оби. О. F in s c h (стр. 161) слышалт, его, между прочимъ. близъ Барнаула. И. Я. С л о вц о в ъ (стр 257) подрпбно пстанавливается на тюменскихъ соловьяхз У Рузскаго, Морозова, Плотникова указаній на нахожденіе. этого соловья нћтъ.

\section{? Erithacus rubeculus Linn. Bopgnkia.}

В Н. Плотников в. (стр. 9) сообщаеть, что эта птичка въ окрестностяхь поселка Ямышевскаго ,пюпадется очень часто. Любить мельніе кустарники, въ которых"ъ и вьетъ гнъзда. Прилетаеть около 20-ги апрьля". Если при опредьленіи этой птички не произошло ошиќи, то имбемъ дъло съ любопытннмъ фактомъ, совершенно неожиданнымт, такъ какт Пермская и Оренбургская губерніи считаютея ., юрайними восточными пунктами распространевія" әтой птичи (М ен зб и р в стр. 991). Во всякомъ случаъ уужна провьрка опредбленія и подтвержденіе указанія В. II ло т н и ко ва

\section{? Janthia cyanura Pall. C.7aba rumexbovt:}

О нахожденіи этпй милювидной птички въ степной части нашего крал пока ничего пе извьстно.

\section{Callope huntschatkensis Gnel. Conbeñ-rincho- meทัณ.}

Насколько поласть распространенія этого чуднаго соловья захватываетъ, стегіну часть нашего крал, епе не вполны выяснено. Вт, щеи частнои коллении имыется красногорлый соловей изъ окрестностей г. Барнаулі, изырепія көтораго здьсь привожу: t ad. 8, vol r. 13 àd. 77 as. 76 c. 65,5 t. 29 แшк.

Вт, литературь степей Западнй Сиоири әтоть соловей не унминатся.

*, Reise nachdem A.tai. Feiträge zur Ke ntniss des russischen Reiches. Bd. 14. 


\section{Cyanecula coerulecula Pall. Baparyutia.}

Мъстн. назван.: ,.синегрудка“ (ст. Убинская и Татарская).

Область распространенія варакушки въ степяхъ нашего края весьма обширна. Ее находили рьшительно всюду, гдъ экспедиціи работали болье или менъе продолжительное время.

Экземпляры коллекцій:

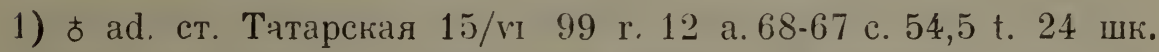

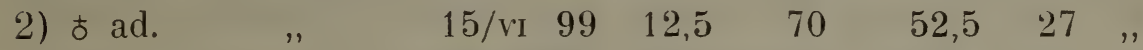
3) sex.? juv. ", $28 /$ vi $99 \quad 9 \quad 65 \quad 46 \quad 24$ ", 4) б аd. ст. Коченево 4/ri $9912 \quad 67$ 53,5 25,5 , 5) sex? juv. ," $\quad 4 /$ wir $99 \quad 11,5 \quad 70 \quad 52 \quad 26$, 6) ad. с. Локэть 14/vi $00 \quad 12 \quad 68 \quad 56 \quad 27$ ",

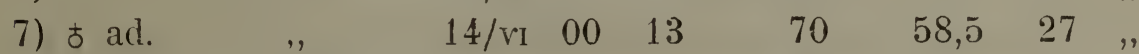

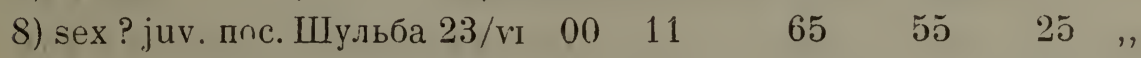
9) баd. д. Чистоозерская 24/vi $02 \quad 11 \quad 69,5 \quad 5526$ 5мум. $\begin{array}{lllllllll}10 . & + \text { ad. } \quad, \quad 28 / \text { vi } & 02 & 12 & 66 & 53 & 27\end{array}$ 11 б ad. с. Ключевое $9 /$ vil 02 11,5 $71,5 \quad 57 \quad 26$ ”, 12) ᄒ ст Семиярская $20 /$ viı $02 \quad 12 \quad 68,5 \quad 56 \quad 27$,,

Изъ пкрестностей ст. Каинскъ я полјчиль отъ П. А. Ш ас т () в с к а г о кладку из'ь 4 яицъ варакушки-синегрудки, найден ную имъ 8.го мая 1903 г. Размъры и еъсъ яицъ въ мм. и гр.:

$$
\begin{aligned}
& \text { 1) } \frac{17,5 \times 13,6}{0,12} \text {; } \frac{17,6 \times 13,5}{0.11} \\
& \text { 3) } \frac{18,0 \times 13,6}{0,13} \text { и 4) } \frac{17,2 \times 13,3}{0,10}
\end{aligned}
$$

Окраска яицъ бльднъе, чъъмъ это передано на рисункахь въ нов. изданіи $\mathrm{N}$ a u $\mathrm{m}$ a n n'a. Какъ извъстно. яйца восточныхъ и съверныхъ варакушекъ нбсколько меньше таковыхъ изъ центральной Европы. Около Барнаула варакушка найдена Finsch'ем ъ (стр. 159); оттуда же я имғю әкз., полученные отъ А П. В ел и жа ни на. $\Phi$ и нш ъ находнлъ эту птичку кром Семипалатинскомк, близъ Колыванскаго завода и получилъ отъ С лов ц о в а экз. изъ окрестностей Омска. И. Я. Словцивъ находиль варакушекъ, въ окрестностяхъ Тюмени и далье н а югъ всюду въ Тобольской губ. (стр 258). Въ южной полось Тобольской губ. найдены варакушки М. Рузским и А. Морозовымъ. 
Въ Акмолинский обл. найдена $\mathrm{A}$. Морозовымъ и экспедиціею П. Г.Игнатова Въ Омскомъ убздь встрбчаетея часто и по В С. Елпатьевскому (стр. 150). В. Н. Плотников в (стр. 9) нашель варакушку въ пос. Нмышевскомъ.

\section{? Cyanecula lencocyana Chr. L. Brehm 3oprka.}

1. Д. Рузскій (стр 17) приводитт зтоть видъ варакушекъ для южной иолосы Тобольской губ́. Другихт указаній на нахожденіе этого вида въ Западной Сибири не имњется.

\section{Sylvia nisoria sibirica Johansen. Subsp. nova. Crab- kล หстребиная сибирстия.}

Cлавка ястребиная добыта экспедиціею проф. Н. Ө. К а щ ен ко 1900 г. близъ с. Локоть въ двухъ экземплярахъ. Нзмбренія ихъ:

1) ᄒ (?) $13 /$ v 00 r. 13,5 a. 87 c. 70 t. 24 шк.

.2) む 14.・r $00 \quad 13 \quad 84.857123$,

Окраска нижней стороны перваго экз. свттлье чьыъ у второго, такъ какъ сырыя поперечныя полосы на горльь, груди и брюхь почти отсутствують, между тьмк какъ оны рызко выражены у второго әкземпляра. Это обстпятельство меня заставляетъ отниситься съ нбкоторымъ недовбріемъ къ значащемуся на этикеткћ перваго экземпляра обозначенію пола. Я склоняюсь видьть въ немъ ㅇ. Такое мижніе подтверждается и указаніями, которыя нахону у М ензбира (Пт. Россіи, стр. 949) и у $Ө$. IIлеск е (Ornithogr., стр. ¿̀), а также сравненіемъ этихъ экзеяпляровъ съ другими, находящимися въ юей частной коллекціи и полученными оть моего друга V. v. Tschusi. Измьренія двухъ посльднихъ 'экземпляровъ, добытыхъ въ Креминь С Сверн. Италія) даютъ нам`ъ сльдующія цифры:

3) о ad. 29/ri 02 (нов. ст.) r. 13 ad. 87 a. s. 87 с 73,5 t. 25,5 шк. 4) i $\mathrm{ad}$. 4/vi $02 \quad " \quad 12 \quad 86 \quad 87 \quad 74.5 \quad 24,5$,

Изъ сравненія изи вреній сльдуеть, что у споирскихъ әкземп. хвостьь немного короче (на 3 мм.), чьмъ у западно-европейских'ь (итальянскихъ); зать̌ъъ и плюсна сибирскихъ экземп. (на 1 мм.) короче плюсны итальянскихт. Окраска сибирскихъ особей въ общемъ на нижней стороньь значительно свътлье, чъмъ у западно- 
европейскихъ. На обьихъ кріинихъ парахъ рулевыхь овлый цвђть у сибирскихъ экземп. развить болье и въ длину и въ ширину, чьиъ у западно-европейскихъ.

Между тьмь какъ только у б итальянскихъ ястребиныхъ славокь заньчаеся на крыльяхь быловатая полоса отъ ободковъ кроющихъ крыла, а у $q$ того же происхожденія эта полоса спвершенно отсутствуетъ, я у нахожу н каждомъ крыль по цвъ бћлыя свьтлыя полосы, образованння бьлыми краями среднихъ и большихъ кроющихъ крыла.

Iумаю, что сравненіе и бо́льшаго числа индивидовъ восточнаго и запацнаго гіроисхожденія подтвердятъ указанныя отличія, которыя позволятъ выльлить западно-сио̆ирскихъ ястребиныхт, славокт. въ осопый подвидт. Предлагак назвать әту форму Sylvia nisoria sibirica subsp. nov.

Въ литературь указаній ца нахожденіе ястребиной славки въ степной части нашего края не имьется; она найдена пока въ качествь обитательницы Алтая и Туркестанскаго прая въ предьлахъ Азіатской Россін.

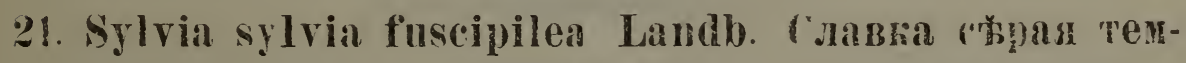

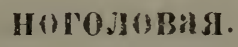

Въ Барабинской степи эта славка мною была добыта въ Убинскимъ ,рям'ь и въ березовыхъ ,колкахъ“ въ степи близъ названной станціи. Въ Кулундинской степи зта славка найдена нами въ березовыхъ и ивовыхъ ,колкахъ“ около дер. Плотниковой. Экспедиція проф. Н $\Theta$. К а щ ен о добыла экз. близъ дер. Саушки.

Экземпляры коллекцій университетскихъ:
1) ᄒ ad. ст. Убинская 8/vi 99 r. 11 a. 73 c. 62 t 21 шк
2) $t$ ad.
$12 /$ vi 99
11
$74 \quad 61 \quad 20 \quad$,
3) б ad. л. Плотникова 13 гі 02
$\begin{array}{lllll}10 & 76 & 61,5 & 21,5 & \text { мум. }\end{array}$
4) ad. д. Саушка
$2 /$ VI 00
$9,5 \quad 75 \quad 64 \quad 21$ шк.

$\mathrm{B} ъ$ моей частной көллекціи:
5) o ad.
$14 /$ vi 98
$10,5 \quad 75$
$67,5 \quad 20 \quad$,
6) $q$ ad.
3 vr 99
11
71
6022 ,

При сравненіи экз. сиоирскаго происхожденія (восточной разновидности) съ экземп. западной формы бросается въ глаза 
окраска верхней стороны, рыжеватый оттьнокъ которой у сибирских'ь экземпляровъ выраженъ гораздо менъе рғзко. Но и среди западныхъ экз. по литературнымъ даннымъ имбются разноокрашенныя особи.

Нахожденіе этой славки въ низенной части Западной-Сибири, повидимому, не особенно извьстно орнитологамъ, такъ какъ у проф. М. А. Мензби ра (IІт. Р., стр. 951) какъ область гнъздовья упоминается лишь Туркестанъ и Алтай. Въ низменной части Сибири эта птичка наблюдалась O. Finsch'е м ъ (стр 155) близъ Барнаула. По И Я. Словцову (стр. 257) эта славка ,,чаще встрьчается въ Ишимскомъ и Курганскомъ округахъ; въ окрестностяхь Тюмени не удалось убить". Въ Акмолинской области С лов цо в ъ наблюдалъ эту славку лишь въ окрестностяхъ горы Джеманъ-тау (стр. 141). Приводится М. Рузскимъ (стр. 16, 17, 21 S. cinerea) для южной полосы Тобольской губ.

\section{2: Sylvia simplex Lath. С.авва садовия.}

$$
(=\mathrm{S} \text {. hortensis Bechst.). }
$$

В下 моей частной коллекціи имбются экземпляры этого вида изъ окрестностей Барнаула и Каинска, доставленные мнђ А. II. Велижанинымъ и П. А. Шас:товским ъ. Свьдыній о нахожденіи садовой славки въ предтлахъ нашего края долго не имълось, хотя извъстно было, что видъ этотт найденъ въ южной полось Тобольской губ. (С ловцовъ стр. 257 и Рузскій стр. 17) и въ окр. Омска (F insch стр. 155, Морозов с стр. 12 и Слов цов с стр. 141). Въ окрестностяхъ Томска эта славка, между прочим' ь, найдена экспедиціею Е. 3 ичи (Е. Zichy) 20/vi 1898 г.

Для сравненія вт моей коллекціи имбется экз. изъ Лифляндіи, любезно диставленный мнъ М. Гермсомъ. Отъ лифляндскаго экземпляра барнаульскій отличается болье свћтлой окраскою, въ особенности верхней стороны.

Измьренія:

1) ᄒ ad. Јифляндія $14 / \mathrm{r} 99$ r. 10 ad. 82 as. 84 c. 61 t. 20,5 шк.

2) ᄒ аd. г. Барнаулъ $10 /$ ri $01 \quad 11 \quad 81 \quad 82 \quad 59 \quad 20 \quad$,

3) ᄒ ad. ст. Каинскъ $7 /$ mil $04 \quad 10 \quad 79 \quad 79 \quad 57,5 \quad 20 \quad$ ", 


\section{¿3. Sylvia curruca affinis Blyth. Conbla-3abupyuta Boreroymas.}

Экспедиція проф. Н. $Ө$. Кащенко 1900 г. цоставила въ нашъ музей одинъ экземпляръ восточной разновидности. Изъ окрестностей Барнаула въ моей коллекции имьется также одинъ экземпляр'ь.

Измьренія:

1) ₹ ad. пос. Шульба 21 н 00 r. 10 а. 6.3 с. 56 t. 19.5 шк.

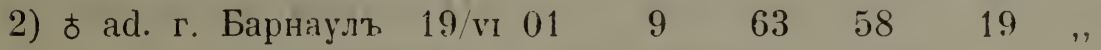

По литературнымъ указаніямь славка-завирушка встрбчается въ Западной Сибири въ объихъ формахъ, восточной и западной. Но только въ рьдкихъ случаяхъ, какъ напр. у В. Бі ан к и. (стр. 5) точно указывается разновидность. Найдена экспедиціего П. Г. Игнатова в'ь Омскомъ у.

\section{Sylvia curruca curruca Linn. Cлi.вка-завирушка затадиая.}

$\mathrm{B}_{\mathbf{b}}$ окр. Томска встрьчается, повидимому, лишь западная форма этого вида. Экспедиція 1900 г. проф. Н. $Ө$. К а щенко кром' сдного экз. восточной формы добыла два экз., которые я считаю принадлежащими къ западной формъ. Съ полной увьренностью этого относительно одного экз. сказать нельзя, такъ какъ у него маховыя частью пострадали отъ выстрьла, но принадлежность другого экз. къ западной формъ несомнънна.

Измьренія:

1) sex? ad. с. Локоть $12 /$ ri 00 r 10 a 64 c. 53,5 t. 18,5 шк.

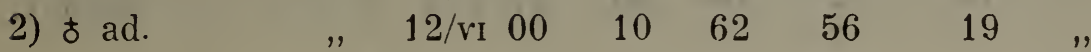

- Къ какой формь относитсл показаніе А. Миддендорфа (Isipiptesen cтр. 46), что этотъ видъ былъ найденъ на весеннемъ пролеть 2/• 43 около Барнаула, неизвьстно. Въ такомъ положеніи я нахожусь и относительно показаній Finsch'a (стр. 155 Омскъ), Сл о ц о в а (стр. 257 Тюменскій и Туринскій уу. Омскъ и Горлкая линія) и Морозова (стр. 12 Омскій и Петропавловскій уу.). 


\section{Sylvia atricapilla Linn. Caran yephorodomba.}

Славка-черноголовка въ степяхъ Томской губ пока не найдена, но въ Омскь экз. этого вида быль добытъ И. Я. С ло в ц овым з, о чемъ сообщаеть $\mathrm{F}$ insch (стр. 155). Проф. M. A. Мензбир в въ „Птицахъ Россіи“ (стр. 967) говоритъ, что „въ Сибири черноголовка не встрбчается". Вышеупомянутый омскій экз. М ензби ръ считаетъ случайно залетнымъ. М. Рузскій однако (стр. 17) въ числь' птицъ, характеризующихъ фауну березовыхъ рощъ юга Тобольской губ. приводитъ и Sylvia atricapilla, a K. M. Дерюгин (стр. 94) дважды наблюдалъ эту славку на съверь Тобольской губ. въ долинь Оо́и.

\section{Regulus regulus cristatus Koch. Voyonesi желт- головый.}

Такъ какъ въ періодъ гньздованія мьстожительствомъ королька являются еловые и пихтовые льса, то естественно, 'то корольки не найдены льтом' въ степной части нашего края. Finsch (стр. 158) приводитъ королька изъ окрестностей Омска, видъннаго въ коллекціи И. Я. Слов цо в а. Самъ Словцо въ упоминаетъ о королькь, убитомъ близъ Омска 21/vi 78. (стр. 141). Сюда же, вЊроятно, относится и показаніе Mорозова (см. ниже).

\section{?. Regulus ignicapillus Ch. L. Brehm. ІІрасноголовый норолент.}

А. Морозовъ (стр. 13) приводитъ красноголоваго королька для окрестностей Омска. Такъ какъ этотъ королекъ птица западно-европейская, думаю, что при опредьленіи А. Морозовымъ допущена ошибка и что онъ имьлъ дьло съ предыдушимъ видомъ.

\section{2\%. Phyllosconus viridanus Blyth. HÆnouna zencmag.}

Пьночка веленая добыта эксшедиціею проф. Н. Ө. Кащенко 1900 г. Въ моей коллекціи имбются экз: изъ окрестностей Барнаула, пріобрьтенные отъ А. П. Велижанина.

Въ гжныхъ округахъ Тобольской губ. эта пьночка найдена И. Я. С лов довым ь (стр. 257) и М. Д. Рузским (стр. 29). 
Измьренія:

1) б ad. г. Барнауль 3, レ 99 r. 8 а. 62 с. 49,6 t. 18 шк.

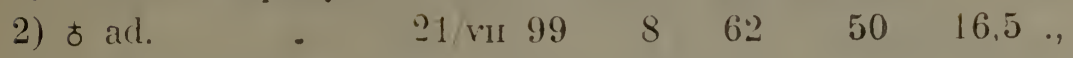

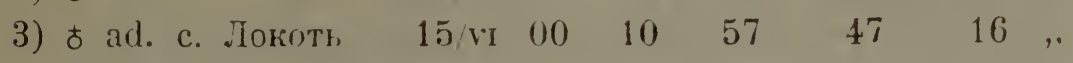

\section{S. Phylloscopus trochilus septentrionalis Ch. L. Brelım*) II жночиа-весничเа.}

Пъночка-весничка населяетъ березовыя рощищы Барабинской степи. Ро время побздки 1899 г. проф. Н. Ө. Кащенко добыль въ окрестностяхъ ст. Татарской одинъ экз. 26-го іюня. Экз. сильно был'ь попорченъ выстрьлом'ь, такъ что нельзя было приготовить препаратъ Изъ окрестностей ст. Каинскъ въь моей частной коллекціи имьется шкурка этой птички отъ П А. Шас тов с ка а'о.

Измьреніе:

1) sex? ad. ст. Каинскъ 18/v. 04 r 9,5 а. 66 с. 50 t. 18 шк.

Изъ литературныхъ указаній отмЂчаю показанія И. Я Словцов а (стр. 257) о нахожденіи веснички въ Тюмени и Курганъ и М. Рузскаго (стр. $16,17,21$.) о нахожденіи ея въ березовыхъ льсах' и болотахъ южной полосы Тобольской г, берніи.

\section{Phylloscopus tristis Blyth. II жночка ;нбирекая.}

Область гнъздовья сибирской пьночки въ степной части нашего края довольно обширна. Fin sch (стр. 157) указываетъ ее для окрестностей Семипалатинска и Омска. М. Рузскій (стр. 17, 21 и 29) находиль ее въ южной полось Тобольской губ́. По сообщенію В. Біанки (стр. 5) эта пьночка найдена въ Омскомъ у. въ 100 в. къ югу отъ Омска экспедиціею П. Г. Иг н а тов а.

Въ меей частной коллекціи имьются экз. изч с. Тулинскаго на Оби и изъ окрестностей Барнаула. Я видълъ ее близъ ст. Семиярской, но добыть не пришлось.

*, E. H a rte rt (toögel pal. Fauna p. 509), ва:ышаеть эту пфночку Ph. trochilus еversmanni Рp पетвертый выпускъ его труда мною полученъ лишь во время печатанія той работы 
Измьренія:

1) t ad c. Тулинское $20 /$ r 96 r. 8 а. 60 c. 51 r. 19 шк.

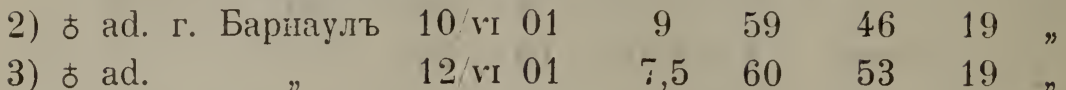

30. Hypolais philomela Linn. Mamnnobra лtспая.

(= Hyp. icterina Vieill).

Малиновка лћсная значительно шире распросгранена на гнъздовьђ вт Западной Сибири, чьмъ можно судить на основаніи литерагурныхъ источниковъ. Fins ch (стр. 158) впервые указываетъ на нахожденіе этой птички въ Западной Сибири на .основаніи экземпляровъ, видбнныхъ имъ въ коллекціи И. Я. Словцова изъ окрестностей Омска. Ө. Плеске (стр. 330) считаеть нашу птичку лишь случайно залетной въ Западной Сибири, а проф. М. Мензбирз (Пт. Росс. стр. 904) даже говоритъ, что „съ переходомъ за Уральскій хребетъ едва-ли наша птичка гнъздится далье березовыхъ льсовъ Башкаріи“. И. Я. С лов ц о в ъ (стр. 257) приволитъ льсную малиновку для Тюмени, Кургана и Шадринска. Въ 1896 г. я въ Ornith. Jahrb. (стр. 138) указал' на нахожденіе этой птички въ окрестностяхъ Томска на основаніи двухъ храняцихся въ Зоол. музеъ нашего Университета экземпляровъ этого вида, добытыхъ проф. Н. Ө. Кащенко и консерваторомъ музея В П. Аникиным въ 1890 и 1894 Гг. Несмотря на перечисленные факты, въ западно-европейскихъ изданіяхъ, въ родъ „новаго Науманка“ умалчивается нахожденіе этой птични въ Сио́ири.

Льсная малинновка принадлежитъ и къ авифаунъ степной части нашего края; по крайней мърђ у меня имъются экэемпляры изъ окрестностей Барнаула, гдъ этотъ видъ по словамъ колдектора А. П. В ели ж анин а нерьдокъ. При опредъленіи барнаульскихъ әкземпляровъ я имьлъ возможность сравнить ихъ съ европейскими әкземплярами, любезно доставленными мнъ V.v. Tschusi изъ Буковины (Glitt) и М. Гермсъ изъ Лифляндіи.

Измъренія:

1) ᄒ ad. окр. г. Барнаула $27 /$ vi 99 r. 11,2 a. 80 c. 56 t. 20 шк.

2) $+\quad$ " $19 /$ vil $99 \quad 11 \quad 76 \quad 56 \quad 19 \quad "$

3) ᄒ Буковина (Glitt) осень $98 \quad 11 \quad 76 \quad 56 \quad 21$ n

4) ᄒ аd. Лифляндія (Замгофъ) $14 /$ r $99 \quad 11,5 \quad 81 \quad 57 \quad 21$ ” 


\section{H!polais salicaria Pall. Buphorymka.}

$$
\text { ( = Hyp. caligata Licht.). }
$$

Бормотушка одна изъ обыкновенньйшихъ гнбздящихся птицъ нашихъ степей. Экспедиціями она найдена какъ въ Барабинской степи, такъ и въ Кулундинской и приалтайскихъ степяхъ и 110 долинь Иртыша Еъ окрестностяхъ стан. Семиярской.

Альбиновъ бормотушки изъ окрестностей г. Омска, добытый 10 іюля 1903 г., спхраняется въ нашемъ музеъ и описанъ мною въ особой статьь̈).

Бормотушка населяєтъ то ивовые кусты, то заросли мальвъ; появ.Іяется и въ огородахъ казачьихъ станицъ.

Экиемпляры коллекцій:

1) ad. ст. Татарская 15/ri 99 r. 10 a. 62 c. 49 t. 21 шк.

2) $q$ ad. $\quad 26 /$ r $99 \quad 11 \quad 59 \quad 46,521 \quad$

3) t ad. $\quad 26 /$ ri $99 \quad$ ? $61 \quad 4920$,

4) + ad. $\quad$ 26/ri $99 \quad 11,5 \quad 59 \quad 47,5$ ?

5) tad. $\quad$ 28/ ri $99 \quad 11,0 \quad 62 \quad 5020 \quad$ "

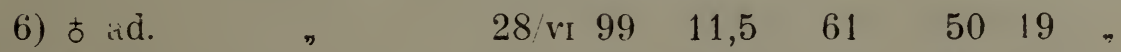

7) $\&$ ad. $\quad 28 /$ vi $99 \quad 10 \quad 60 \quad 4920$ "

8) ᄒ аd. с. Убинское 26/vi $00 \quad 10,2 \quad 61 \quad 5220,5$,

9) sex? ad. д. Нижній-Кучукъ $5 /$ vil $02 \quad 10 \quad 59,5 \quad 51 \quad 19$ мум.

10) sex? ad. с. Кілючевое $10 /$ vil $02 \quad 11 \quad 59 \quad 48 \quad 20$ "

11) sex? ad. ст. Семиярская $23 /$ vil $02 \quad 11 \quad 58 \quad 49,520$ n

12) juv. sex? " $\quad 20 /$ vil $02 \quad 1$ ? $58 \quad 46 \quad 19,5$ n

13) б ad. ст. Каинск' $16 / \mathrm{v} 04 \quad 10 \quad 58 \quad 48 \quad 19$ шк.

Посльдній экземп. въ моей частной коллекціи. Окраска всъхъ экземпляровъ болье или менье одинаковая, характерная для взрослыхъ бормотушекъ; лишь экз. № 12 рћзко отличается отъ остальныхъ своею окраскою, такъ какъ на верхней и гижней сторонахъ ясно замътенъ рыжеватый тонъ, переходящій на нижней сторонъ даже въ желтоватый (признакъ молодыхъ птицъ).

Длина маховыхъ колеблется. У большинства экземпляровъ мы находимъ нормальное отношеніе, т. е. второе маховое короче шестого и длиннъе седьмого. У нбкоторыхъ әкземп. второе маховое длиннъе шестого.

*) Cм. Ornith. Monatsherichte. Juniheft 1904. Vollständiger Albino von Hypolais salicaria Pall. 
Странно, что Fins ch совершенно не упсминаеть бормотушки въ свпемъ трудь. Приводится И. Я. Словцовымъ (стр. 257) для Тюмени и Кургана, а также для Горькой линіи и г. Ишима (стр. 141). М. Рузскій (стр. 17 и 20) нашелъ бормотушку въ южной полось⿱ 丂 Тобольской губ. А. Морозовъ (стр. 13) приводитъ нашу птичку для Омскаго и Петропавловскаго уу. и Ишимскаго округа. Экепедиція П. Г. Игнатова нашла бормотушку въ Омскомъ, Акмолинскомъ и Атбасарсковъ уу. (Б і а н и и стр. 5).

\section{Acrocephalus schoenobaenus Linn. Kannuerka бap- сучен'ь}

$$
\text { (= Acr. phragmitis Bechst.). }
$$

Матеріаль относительно этого вида, находящйся въ моемъ распоряженіи, довольно общирный. Мы находили эту камышевку какъ въ Барабинской степи, такъ и въ Кулундинской. Проф. Н. Ө. Ка щенко добылъ этотъ видъ въ приалтайскихъ степяхъ. В7, моей частной коллекціи имьется 8 экземпляровъ изъ окрестностей Барнаула, добытыхъ А. П. Ве ли жаниным ъ.

Экземпляры коллекцій:

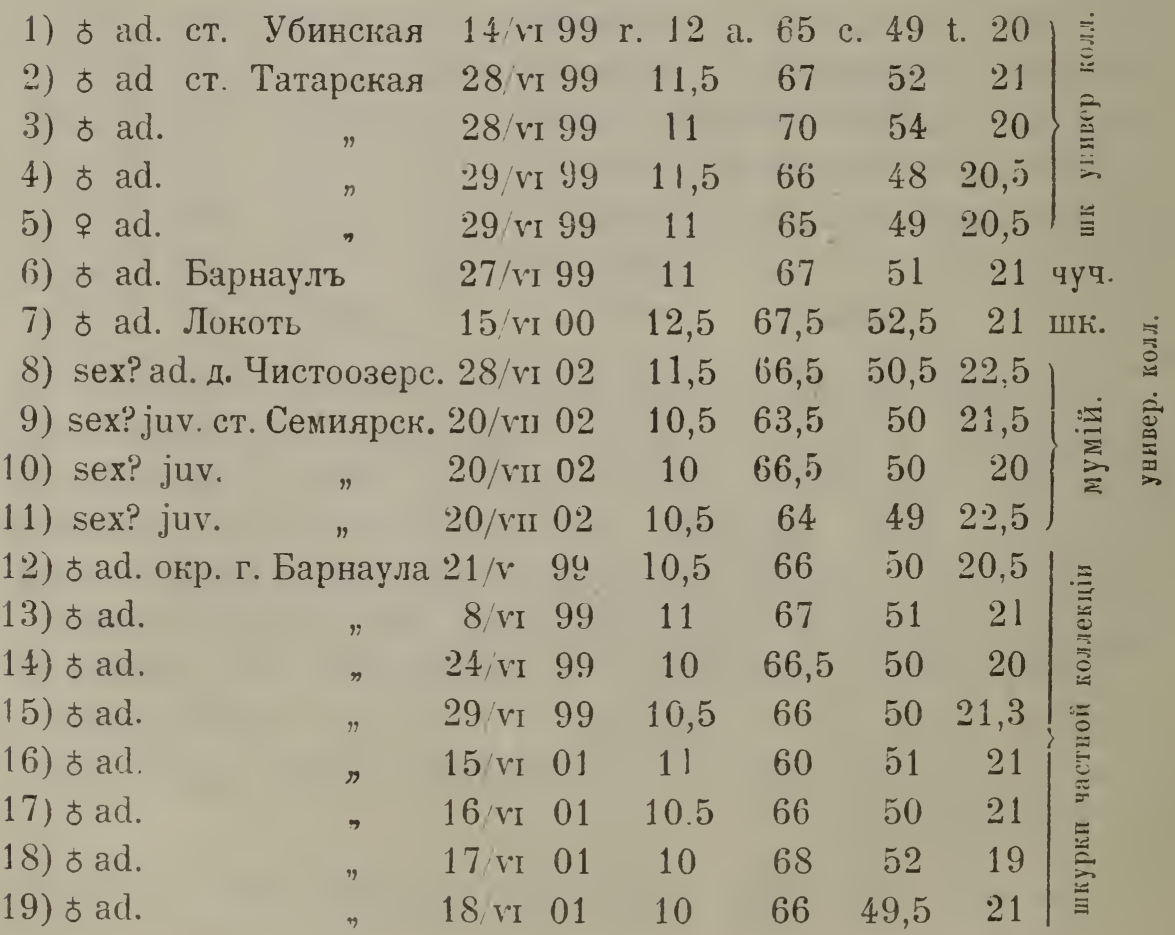


Что касается относительной длины маховыхъ, то я нашелъ у экземпляровт коллекцій значительное разноибиазіе: въ большинствь случаевт, 3-е маховое больше 2-го, котојое в'ь свою очередь длиннће 4-го. Во многихъ случаяхъ 2.0е маховое является самымъ длиннымъ, причемъ 4-ое короче 3-го. Есть экземпляры, у которыхт, 2-ое по длинь равно 4-му. У большинства экземпляровъ правое крыло вполнъ симметрично съ львымъ. Но у нбко. торыхъ экземпляровт формула праваго крыла выражается $2=3>4$, львое же $2>3>4$ или львое $2>3>4$, а правпе $3>2>4$.

Замбччательно, что у барнаульскихъ экземпляровъ сбора 1899 г. формула крыла $3>2>4$, а у әкземпляровъ барнаульскихъ сбора 1901 г, за исключеніемъ одного, формула $2>3>4$.

Окраска трех'ь экземпляровъ изт ст. Семиярской значительно ярче другихъ; особенно замбтно это на нижней сторонь, поторая у нихт, желтовато-охристаго цвъта Темныя наствольныя пнтна на головћ, расположенныя почти правильными полосами, у әтихъ трехъ әкз. кажугся болье яркаго, олестящаго чернаго цвъта. У нихъ же болье или менъе хоропо развито на грули ожерелье, состояцее изъ бурыхъ ошейниковыхъ пятнышекъ. Эти три әкз. считаю молодыми (ср. Ө. Плеске стр. 442).

Для Тобольской губ. наша птичка приводится И. Я. Словповымъ (стр. 256) и М. Рузския (стр. 23). Гіъ Акмолинской области найдена И. Я Словцивымт, (стр. 141) У другихъ, приводимыхъ въ, этюй работь авторовъ, камышевка.барсучекъ не упоминается.

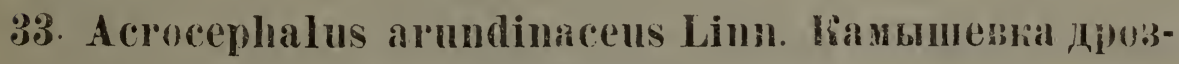 довидная.}

(Acr. tzirloides leỵer).

Дроздовидную камышевку намь удалось найти тплько вт liyлундинкой степи близъ дер. Чистоозерский, гдь она населяетъ камышевыя и тростниковыя заросли. которыми покрыты озера б.лизъ названной деревни. Во время нашего пребыванія въ этой деревн п пьніе самцовъ еще не шрекратилось, хотя дъти были ужн величиною почти съ взросльхъ и хорошо летали.

Г'уководствомъ при опредъленіи служила . Ornithogrophia“ $\theta$. H.леске. 


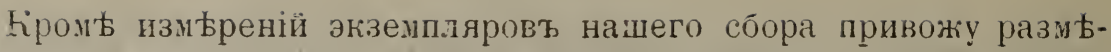
ры двухъ экземпляровъ моей частной коллекціи изъ Съверной Италіи (Cremona), съ которыми добытые әкземпляры были тщательно сравнены:

1) $t$ ad дер. Чхстоозерская 26/vi 02 r. 19 а. 97 с. 83 t. 28 шк.

2) 우 ad. $26 /$ vi $0218,5 \quad 93 \quad$ ? 27 "

3) sex? ad. $26 /$ r $02 \quad 18 \quad 93 \quad 81$ 29 мум.

4) sex? ad. 26 เі 02 1896 81 29 "

5) sex? juv.

6) $q \mathrm{ad}$.

Cremona 26 मr 02 1373 $25 / \mathrm{r} \quad 02$ 1792

7) ᄒ $\mathrm{ad}$. $26 / \mathrm{r} \quad 0$ $20 \quad 95$ 46 25 "

Нахожденіе дроздовидной камышевки въ нашемъ краъ заслуживаеть вниманія, такъ какъ этимъ, пополняется прсбълъ въ ея геюграфическомъ распространеніи и добытые экземпляры являются первыми для нашего музея. /la.ı.асу (стр. 458) ничего не извъстно о нахожденіи его "Turdus junco" Вт Сибири, такъ что первын'ь, упоминающимъ эту камышевку для Сибири являегся Ф. Грандтв въ его спискь животныхъ, помьщеннимъ вт путешествіи Чихачева (стр. 442 nomen nudum!). Но при этомъ остается Еевыясненнымъ, имълъ ли онъ дьъло съ этимъ именно видомъ, такт, какъ по югозападной окраинь Сибири встрбтгется и дрұсгой близкій видъ (Acr stentoreus Hempr. et Ehrbg). Оюа вида долге вреия не отличались другъ, отъ друга орнитологами, даже H. А. Свеерцивылг. и др. Њременская әкспедиція 1876 г., во глав Б которой стоялъ O. Finsth, хотя и приводитъ этоть видъ для Ала-куля, Чернаго Иртыша и Зайсанъ-Нора, но ею не добытъ

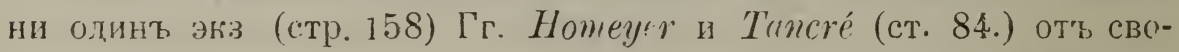
ихъ ноллекгоровъ съ Алтая и прилегающихъ иьстностей также не получили ни одного экземпляра. A. М. Николискимо (стр. 99) дроздовидная камышевка найдена въ долинь Или и при усть Лепсы На основдніи приведенныхъ данныхъ ойласть распространенія нашей птини $\theta$. Z. П.леске и il. A. Мензбиромь расширяется на вистокъ отъ Европ Россіи до Алтая

Изъ западно-сиобирскихт, степей эта камышевка стала извьстной благодаря изсльдованіямъ 21 . Д. Рузскало въ южной полось Тобольской губ. (стр. 23 и 24), а также L: $Г$. Ньнатова въ Акмолинской области (см. Біанки стр. 6). 
Накюнець, во время печатанія этой работы, я получиль оть II. A. IIІастовскию ньсколько яицъ этой камышевки, собранныхъ имъ въ Гаинскомъ убздь 26-го мая 1907 г. Дроздовидная камышевка, по его словамъ, на нбкоторыхъ озерахъ встрычается мессами. Я измбрилт двь кладки:
А. 1) $22,0 \times 16,0$ мм.;
2) $21,7 \times 16,0$ мм.
0,17 гр.
0,17 гр.
и 3) $\frac{21,5 \times 16,2 \text { мм. }}{0.18 г \mathrm{rp}}$

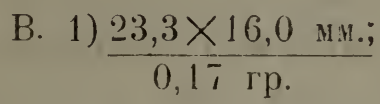
2) $\frac{24,0 \times 16,0 \mathrm{~mm}}{0,16 \mathrm{rp}}$

По окраск' яйца кладки А наиболье приближаются къ рис. 22 таб̆л. 26 Naumann'а, но пятна больше, сливаются между собою, образуя значительныя оливковыя иространства. По окраскь и величинь пятенา, яйца кладки В почти тождественны съ указаннымъ рисункомъ, но основнпй тон'ъ лишенъ зеленоватаго оттћнка, ясно замћтнаго иа рисунк'.

\section{- Acrocephalus palustris Bechst. liand шевка бo.aотная.}

Видъ этотъ. вт, Западной Сибири не ветрбчается. Упоминаемый Finsch'емг (стр. 158) экз. этого вица изъ окрестностей (мска въ колл. Н. Я. (ловцова впослАдствіи оказался иевьрно опредъленнымъ и принадлежащимъ къ $A c r$. dumetorm Blyth. (Сравн. Ө. ,I. Н.иеске стр. 541).

\section{Acrocephal Ins dumetorum Blyth. Lianышевка садовая.}

Садовая камышевка гнбздится, по Мензбир!у и П.иеке, въ Западной Сибири и на Алтађ. Намъ попадалась въ огрестн. Томска и в’ъ Маріинскомъ убздт, въ степной части нашег кран добыта лишь близт, Барнаула $A$. II. Ве.и.жанинымъ. Гг. Hомеyеr и Tancré (стр. S⿺辶, повидимому, получали ее неоднократно отъ своихъ коллекторовт. Finsch опио̆оно приняль эк:з изъ окрестностей Омска въ коллекціи Н. Я. С.юоилов за Acr. palustris (стр. 1581. По М. Pузскому (стр. 17) эта камыневка населяєтъ

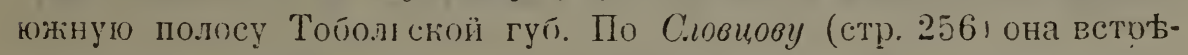
чается въ южныхъ округах’ Тобольской губ., Йшимскомъ и Курганскомъ, чаще чьиъ вं. Тюменскомъ и Туринскоміз.

Размьры цвухъ экзеипляровъ изи окр. Томска.
1) 8 ad. 31 r 49
1.
11.5 a.
63,5
c. 55 t. 21 шк.
$2)$ ㅇ ad. 8 w 99
11
59.5
$50.5 \quad 2.2$ 


\section{Acrocephalus agricolus Jerd. Randшевка индіисан.}

Эту камышевку я находилъ въ большомт количеств в въ Ку. лундинской степи на большихъ озерахъ (Грачевое) близъ дер. Чистоозерской, гдђ она населяла тростниковыя заросли по по. бережыю и на островахъ. Гньздо ея, найденное $22 \cdot$-го іюня 1902 г, уже покинутое, помьщено въ нашъ музей. Капышевка эта до сихъ поръ была извъстна только съ Алтая въ качествђ гиъздящейся !по мнбнію $\theta$. Плеске) птицы. Но гнбздится ли она на Алтаъ, пока еще не доказано, такъ какъ единственный экз. изъ этой м'九стости, на основаніи котораго $\Theta$ Ilлеске говоритъ о ея гнБздовь Ђ, добытъ г. Карелиным на Иртыгы въ апрьль 1843 г. Я считаю әтотъ экземпляръ пролетнымъ. На Алтаь ни проф. $Н \Theta$. Кащенко, ни мною индійскяя камышевка не была найлена, хотя этимт, разумьется не отрицается возможность ея тамь гнђздовья. Изсльдованія M. Д. Рузскаго (стр. 23 и 29 обнаружили присутствіе этой камышевки въ южной полось Тобольской губ, гды ана также, какъ и в'ь Һулундинской степп, населяетъ, „камышевыя и тростниковыя заросли озеръ “. Экспедиція /I I. Нюнатова досіыла эту камышевку в'ı, Атбасарскомъ убздь. (Біаняе стр. 6).

Экземпляры коллекціи:

1) sex? ad. д. Чистоозерская $24 /$ r 02 r. 10 а. 56 c. 52.5 t. 21 мум.

2 t ad $\begin{array}{llllll}28 / \text { r } & 02 & 11 & 53 & 50 & 20\end{array}$

3) $\subsetneq$ ad. $2 S /$ rI 02 $11.55955 .521 "$

Въ таблиць для опрецђленія видовъ $\Theta$. IПлеке (стр. XL) сообщаетъ, что у этой птичाи хвлсг' равной длины съ крыломъ. $\mathrm{Cъ}$ этим, не согласуются результаты изыьреній нашихъ экземпляровъ, но это ббстоятельство не должно наводить соянбініе вт, правильности меео опредьленія, такъ какъ и у самого /l.еске (стр. 559 и 560) измьренія длины хвоста и ғрыла этихт: птичекъ далеко не всегда даютъ одинаковыя цифры. Разница по его же таблицамъ въ цлинь этихъ частей доходитъ до 3 и даже до 5 мм.

\section{- Lusciniola fonsata Plyth. liambuebra ronliosiboba chópcisa.}

Этотъ восточнп-сиоирскій видъ заходитъ въ нашъ край до Оби, гдь онъ населяетъ одни и ть же мьста єъ варакушкой. Экспедигія проф. Н. Я. Кіащенко добыла одинъ экзз. этой итички 
близъ Устп-Чаусской пристани (г. Кілывань) на Оби 25-го мая 1898 г. Я находиль ее нысколыго раз'ь (впервые 10-го іюня 1896 г.) вา, окрестностяхь Томска и вт Маріинскомб у. въ окревтн. ст. Красной.

Измьреніе:

1) む. Јсть-Чаусъ $25 /$ r 98 r. 9 а. 63 с. 55 t. 22 шк.

\section{Locustella finviatilis Wolf. lianыневка płчная.}

Заходитъ ли эта камышевка въ предълы Томской губ. съ за. пада, пока неизвъстно. По мнънію проф. М. А. Мензбирz (стр. 862) эта птичка находитъ восточный предъль своего распространен ія въ тобольской губ., гды она найдена И. Я. Словиовылъ (стр. 256) въ Тюменскомъ огругъ, а изрьдка встрьъчается и въ Туринскомъ. Новьйшія изсльдованія $M$. Д. Рузскаго (стр. 27) обнаружили присутствіе ея и въ Курганскомъ у., гдъ ее находили „въ тяльниковыхз заросляхь около озеръ“. В. Н. Плотниковъ (стр. 9) называетъ эту птичку довольно обыкновәнной по зарослямъ, рагтущимъ по берегамъ проточекъ и озеръ, гдъ она и гнььздуетъ (близъ пос. Ямышевскаго на Иртывь)). Нами въ степяхъ нашего края не найдена.

\section{Locustella certhiola Pall. hambuевнa-кобылочка.}

ПI. С. ІІалласг, давшій первое описаніе этой камышевки, такъ же какъ проф. M. A. Мензбирг, гг. Hотеyer и Tancré, Finsch и др. или не приводятъ западно-сибирскихъ мьетъ нахожденія этого широко распространеннаго въ Восточной Сибири вида, или же совершенно умалчиваютъ о немъ. У $\Theta$. Д.. II.еске мы находимъ указаніе на нахожденіе әтого вида на Алтағ. Онъ же упоминаетъ объ одном'ь экземплярђ, убитомъ въ Западной Сибири, шринесенномъ въ даръ Зоол. музею Академіи Наукъ отъ И. Я. Словцова, но, къ сожальнію, неизвъстно, гдъ былъ дюбытъ этотъ экземпляръ. Ообщепринято считать эту пгичку гнъздящейея „въ системъ Алтая и въ Сибири между Енисеемъ и берегами Тихаго оке-

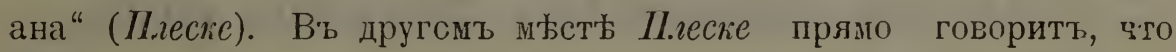
она „не гнђзлится западнъе долины р. Енисея“. На самомь дъль область гньздовья этой птички идетъ гораздо далье на западъ. Мною эта камышевка была найдена уже въ 1896 г. въ 
окрестн. Г. Томска и во множеств है на усть ныя). А. ІІ. Велижанинг добылъ ее въ значительномъ числь эквемпляровъ въ пкрестностяхъ г. Барнаула; въ Нарымскомъ крағ она найдена $B$. II. Аникинымо.

Въ Кулундикской степљ она намъ попадалась въ камышахъ и хвощахъ на большихь озерахъ близъ дер. Чистоозерской, но экземпляръ былъ сильно разбитъ, такъ что онъ не сохраненъ. Измьренія әкземп. моей коллекціи.

1) ᄒ ad. өкр. г. Барнаула 5 vi 01 r. 12 а. 67 с. 55 t. 21,5 шк.

2) $ᄒ$ ad.

$5 /$ ri 0

13

71

57

$22 "$

3) ᄒ ad.

$6 /$ vI 01

1368

20,5

\section{Locustella locustella straminea Ssew. Kaишшевка- сверчок'ь.}

Пъніе камышевки-сверчка я слышалъ въ окр. дер. Чисто озерской, но добыть птички не удалось. Изъ окрестностей г. Барнаула отъ А. П. Велижанина въ нашемъ музеъ чучело, а въ моей ко.лекціи шкурка.

Экземпляры:

1) ᄒ аd. г. Барнауль 24/vi 99 r. 11 a. 55 c. 54 t. 19 чуч.

2) sex? ad. $\quad 18$, 'i $01 \quad 11 \quad 54 \quad 51,5 \quad 18$ шк.

Какъ на обитательницу южнаго склона Алтайскаго хребта указываютъ на эту камышевку $\theta$. Д П.леске (стр. 615) и $M . A$. Мензбир (стр. 869 и 871). Найдена в’ Туркестан' и Киргизскихъ степяхъ.

\section{- Locustella lanceolata Temm. Rambuевка пятнстал.}

Пока ничего не извђстно о нахождении этого вида въ степной части нашего края. Въ Томскь найдена мною и $B$. II. Аникинымъ (см. Ornith. Jahrb. XIII 1902 стр. 166).

\section{? Accentor modularis Linn. Завирушка льсная.}

А. Морозовъ (стр. 13) со словъ ПІ. И. Сотникова приводить этотъ видъ; другихъ указаній на нахожденіе этого вида въ Западной Сибири нб̆тъ. 


\section{Accentor atrogularis Brandt. Зaвupymbal черно- горлая.}

При описаніи этого вида академикт Ф. Брандтг (1844) уноминаетъ Семипалатинскъ какъ мъсто нахожденія этой птички. По H. E. Dresser'y (стр. 152) она встрьчается въ Киргизскихъ степяхъ. O. Finsch (стр. 167) получилъ әкземпляръ изъ окрестностей Омска отъ И. Я. Словиова (см. его Пут. записки 1897 стр. 142). Вотъ и все. что мнђ извъстно о нахожденіи въ низменной части Западной Сибири этой широко распространенной на Алтаб и Тянк-Шань птички.

\section{Cyanistes cyanus Pall. Jasopeвla бълая.}

Б券ая лазоревка широко распространена въ качествь гнбздящейся птички въ степяхъ нашего края, гды есть древесная растительность. Въ Барабинской степи близъ станц. Калачинской 25-го іюнй 1899 г. проф. Н. $\theta$. Кащенко убилъ 4 экземпляра изъ стайки штукъ въ 10 въ березовомъ и тальниковомъ колкЂ. Все это молодые экземпляры съ сћроватымъ теменемъ, окруженнымъ широкой бъловатой полосой. Экспедиціею проф. Н. $\Theta$. Кащенко 1900 г. эта синичка была добыта 23-го іюня близъ пос. Шульбы. Отъ А. II. Велижанина я получилъ экземпляры изъ окрестностей г. Барнаула.

Экземпляры коллекцій:

1) ᄒаd. окр. г. Барн. 18/vin 98 r. 8,5 а. $69-68$ c. 66 t. 15,5 шк.

2) б јuv. ст. Калачин. $25 /$ vi $99 \quad 8,5 \quad 68 \quad 62 \quad 16$ "

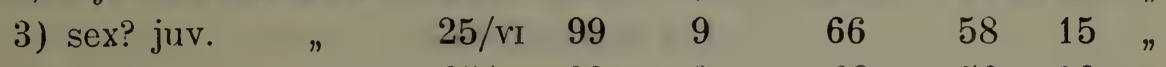

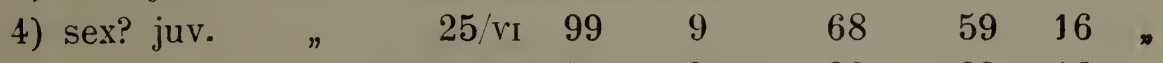

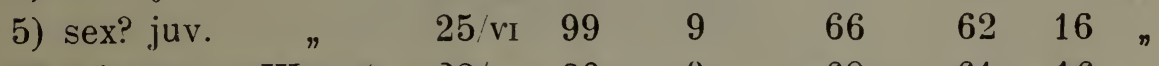

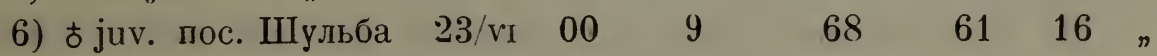

По литературнымъ указаніямъ эта синичка, широко распространенная по Сибири, приводится O. Finsch'емъ (стр. 170) для Омска, И. Словиовымг (стр. 255 и 142) для Акмолинской обл, M. Рузскимъ (стр. 17 и 21) для юга Тобольской губ, A. Морозовымг (стр. 11) для Омска, В. Н. Плотнитовымг (стр. 6) для окрегтностей Ямышевскаго поселка въ качествъ зимующей птицы. Въ степяхъ открытыхъ, безъ колковъ и перельсковъ, лазоревка отсутствуетъ. 


\section{Parus major Linn. Синцц большая.}

Мъстн. назв.: „мясникъ“ (дер. Чистоозерская).

Синица болышая въ степяхъ нашего края довольно обыкновенное явленіе. Ее находили какъ въ Барабинской степи, такъ и въ Кулундинской. Въ окрестностяхъ ст. Каинскъ она и зимою неоднократно попадалась П. А. Шастовскому. Голыя, лишенныя древесной растительности степи однако избъгаются ею. Бора, какъ напр. Кулундинскій близъ с. Вылкова пли Сњверный близъ с. Ключевого, затьмъ рощицы, сохранившіяся близъ деревень, служатъ м'ьстами ея гнъ̆здовья. Экеемп. коллекціи:

1) ᄒ. с. Вылково. $21 /$ г 02 r. 10,5 а. 74 с. 64 t. 21 мум.

Изт литературныхъ данныхт любопытно сообщеніе O. Finsch'a (стр. 167) о томъ, что большая синица, по сьздъніямъ, полученнымъ отъ $И$. Я. Сяовиова, появилась в' 1877 г. въ Омскь $17 / 29$ марта. Какая можетъ быгь рьчః о времени появленія пернатаго, которое въ теченіе всей зимы не покидаеть Сибири, а живетъ осьдло въ льссной ея области, предпринимая лишь небольшія кочевки? Въ Тобольской губ. большая синица найдена всьми работавшими надъ изученіемъ ея авифауны. Въ окрестностяхъ пос. Ямышевскаго на Иртыш встрбчается, по B. H. 11.几оникову (стр. 6), въ качеств Б́ осьдлой птички. Въ Кокчетавскомъ

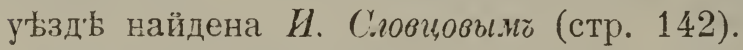

\section{Parus borealis baicalensis \$winh. Paичh cuбиperas тусклоголовая.}

(Poecile macrura Tacz.).

Въ Кулундинскомъ бору у с. Вылкова довольно обыкновенна, а такње и въ Съверномъ бору близъ с. Ключевого.

Экземпллры коллекцій:

\begin{tabular}{|c|c|c|c|c|c|c|c|}
\hline $\begin{array}{l}\text { 1) sex? c. } \\
\text { 2) sex? }\end{array}$ & Вылково & $\begin{array}{ll}17 / \text { vi } & 02 \\
21 / \text { vi } & 02\end{array}$ & & $\begin{array}{l}66 \mathrm{c} \\
61,5\end{array}$ & $\begin{array}{l}62 \mathrm{t} \\
61,5\end{array}$ & $\begin{array}{l}19 \\
18\end{array}$ & n \\
\hline 3) sex? & 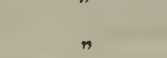 & $21 /$ rI 02 & ? & 61 & 57 & 17 & $"$ \\
\hline 4) $\operatorname{sex} ?$ & Ключев. & 9 เท 02 & 10 & 62 & 60 & 17 & \\
\hline sex? & r & $9 /$ VII 02 & 9,5 & 64 & 61 & 17 & \\
\hline 6)・ sex? & $n$ & 9 rin 02 & 10 & 64,5 & 61 & 18,5 & , \\
\hline
\end{tabular}


Гаички сосновыхъ боровъ Кулундинской степи не этличаются отъ томскихъ, вмъсть съ которыми характеризуются сравнительно длинной, черной, матовой шапочкою, сравнительно большимъ горловымъ пятномъ, свђтлосђрою спиною. почти бђлой нижней стороною, почти бълыми каймами маховыхъ и крайнихъ рулевыхъ, при чемъ хвостъ ступенчатцй. Имья въ своей коллекціи большой матеріалъ изъ разныхъ мъстностей для сравненія, я не могу не согласиться со взглядомъ C E. Hellmayr'a и считаю сибирскихъ тусклоголовыхъ гаичекъ за $P . b$. baicalensis Swinh, отличающихся отъ сьверо-европейскихь $P . \quad b$. borealis Sel. Lonych. нъсколько большими размЂрами и болъе свЂтлой окраскою.

Изъ другихъ частей чашихъ степей экземпляровъ въ коллекціяхъ нбтъ. II. A. IIастовскій не находилт гаичекъ въ окрестностяхъ ст. Каинскъ. И. Я. С.юовиов для окр. Омска и Кокчетавскаго ућзда (стр. 142) приводить P. camschatkensis Br.

\section{- Periparus ater Linn. Cnmua-nocrobra.}

Московка, повидимому. совершенно не заходитъ въ степную часть нашего края. Въ, коллекціяхъ экземпляровъ нбтъ, нътъ и указаній въ литератур‡, если не считать замътки И. Я. Словиова (стр. 255). Мюсковка-обитательница льса.

\section{Aegithalus caudatus Linn. Cnmiga долгохвостая.}

Какъ московка, тамъ и долгохвостая синичка вљ степяхъ намъ не попадалась. Въ Тюменскомъ и Туринскомъ округахъ по С.ювиову (стр. 256) живетъ круглый годъ. Упоминается $A$. Морозовымг дла Омска (стр. 11 nomen nudum!) и $M$. Рузскищи (стр. 19) для бора на Иртышћ. II А. НІастовскій вт огрестн. ст. Каинск' долгохвостой синицы не находилъ.

\section{Aegithalus (Remiza) stoliczkae Hume. Pemer ch- биpckili.}

Ремезъ несомньнно гнъздится въ Барабинской и Кулундинской степяхъ. Изъ первой въ нашемъ музеъ сохраняется гнбздо ремеза, присланное птатнымъ смотрителемъ училищъ $A$. A. Арчуновымг. Оно найдено въ 1898 г. близъ дер. Барсуковой, Каинскаго у. Изъ окрестностей ст. Каинскъ я получилъ огъ $L$. $A$. 
IIастовскало найденное имъ 18 мая 1903 г. на осинъ гн'ьздо ремеза, въ которомъ находилось одно яичко. Ііз сожальнію пттица не была добыта. Птицъ въ описываемыхъ коллекціяхъ вообще нбтъ; я поэтому самъ лишенъ возможности ознакомиться съ әтимъ интереснымъ представителемъ нашей фауны и привожу его подъ названіемъ stoliczkae лишь согласно работь B. .I. Біанки (Catalogue of the known species of the paridae. 1902 стр. 24). Длина яичка изъ Барабы 15 мм. при ширинб въ 9,5. ВЕсъ скорлупы 0,06 гр. По разсказамъ мъстныхъ жителей ремезт гнЊздится въ окрестностяхъ ст. Убинской; гнъзда его разыскиваются, такъ какъ считаются цьлебнымъ средствомъ. То-же мнъ сопбщали въ Кулундинской степи въ дер. Чистоозерской. Въ окрестн. станицы Семиярской $B$. $M$. Трухинъ разъ нашелъ гнбъздо въ тальниковыхъ зарослях'ь по Иртышу.

B. H. ПІютниковб (стр. 6) приводитъ ремеза для окрестностей пос. Ямышевскаго на Иртышь, но называеть этого ремеза Parus pendulinus Linn. Врядъ ли европейскій видъ заходитъ такъ далеко въ Сибирь! Изъ Тобольской губ. ремезъ извъстенъ благодаря работамь И. Я. Словщова (стр. 256) и М. Гузскало (стр. 30). Они тоже говорять лишь объ Aeg. pendulinus.

\section{- Panurus biarmicus sibiricus Bonap. Cиниц усатая.}

Синица усатая въ степяхъ нашего края не найдена. Finsch добыль на оз. Норъ-Зайсанъ вь конц в мая 1876 г. шесть экземпляровъ этого вида.

\section{Sitta uralensis Licht. IIонолень сибирспій.}

Поползень намъ въ степяхъ не попадался, но по разсказамъ мъстныхъ жителей встрьчается въ борахъ Кулундинской степи, напр. близъ с. Ключевого.

M. Рузскій (стр. 19) нашелъ поползня въ бору на Иртышь въ Тобольской губ И. Словцовъ (стр. 255) нашелъ его обыкновеннымь обитателемъ льсной полосы Тюменскаго и Туринскаго округовъ и добылъ экз. въ Аиръ-тау (Кокчетавск. уызда) (стр. 140). Гнъздится близъ Омска, гдъ $H$. Тихомировымъ $17 / \mathrm{v} 0$ อ найдено въ дупль гнъздо съ 5-ю ненасиженными яйцами. 


\section{Certhia familiaris scambulaca Pall. Cubupchas}

\section{IIIILY Xa.}

Пищуха въ степяхъ нашего края пока не найдена. Finsch видълт, в' коллекчіи Словиова экземпляры изъ окрестностей Омска (стр. 154), откуда цриводится Н. С.љовиовы.иг (стр. 141) и А. Мпрозовымб (стр. 13). Но (єовиову (стр. 253) найдена в' Тюменскомт и Туринскомъ округахъ.

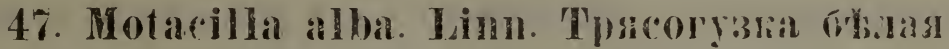

Мћстн. назв.: „синюшка“ (с. Вылково и др.), „плисикъ“ (дер. Чистоозерская).

БЪлая трясогузка широко распространена на гнъздовь Б въ стєпяхъ нашего края. Мы нахгдили ее рышительно всюду, гдб есть вода.

Экземпляры коллекцій:

1) sex? juv. ст. Убинская 8/r. 99 r. 10,5 a. 84 c. 75 t. 20 шк.

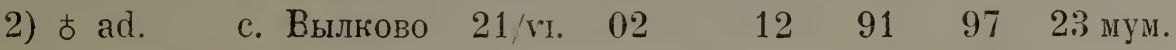

По Hartert'y область гнъ̆здовья типичной бълой трясогузки (M. alba alba Lin.) прпстирается на востокъ лишь до Урала, а въ Западной Сибири до Енисея и Алтая по его мнбнію гнъздится уже M. alba dukhunensis Sylies. Просматривая экз. коллекцій я нахожу, что по окраскъ спины әкз. могли бы быть отнесены къ dukhunensis. такъ какъ она, дъйствительно, значительно свътлъе, чъмъ у экз. изъ Лифляндіи и Таврической губ.., но другого признака, характернаго для формы dukhunensis, большаго развитія бълаго цвъта на среднихъ и большихъ верхнихъ кроюшихъ крыла, я у западно-сибирскихъ экз. не замбчаю, а потому пока привожу бълыхъ трясогузокъ нашихъ степей подъ однимъ лишь видовымъ названіемъ.

Въ Томскь весною встрычаются впрочемъ и M. alba baicalensis Suinh.

\section{Motacilla personata Gould. Tpgcoryska Mackupo- ванная.}

Экспедиція проф. Н. $\Theta$. Каиенко добыла экземпляръ этого широко распространеннаго на Алтағ и въ Туркестань вида въ дер. Сауџш'ь; эта же трясогузка найдена въ пос. Шульбьь. 
Измьреніе:

1) $q$ ad. дер. Саушка $2 /$ vi 00 r. 13 а 85,5 c. 91 t. 22 шк.

Въ болье сьверныхъ частяхъ степей нашего края эта трясогузка пока не наблюдалась. Finsch (стр. 172) видъль ее на рькъ Алей.

\section{Motacilla boarula melanope Pall. T'uscoryzka rop- ная сио́ирсkas,}

По сообщенію П. А. ПІастовскаго эта трясогузка гнћздится въ окрестностяхъ станціи Каинскъ. А. Н. Ве.ижанинъ досгавилъ мнъ әкземпляръ изъ окрестностей Барнаула. Во время пођздокъ по степной части нашего края этотъ видъ намъ не попадалея

Измьреніе экземпляра моей частной коллекціи:

1) ․ Окр. г. Барнаула 26/vш 98 r. 12 а. 84 с. 97 t. 20 шк.

Finsch (стр. 177) видбль въ коллекціи Словиява экз, изт окрестностей Омска. Экспедиціею $П ., I$. Нънатова этоть видъ найденъ вт Акмолинскомъ у. Другихъ указаній на нахожденіе въ степяхъ нашего края этого пироко распространеннаго на гнъздовь Б въ Сибири вида нътъ.

\section{Motacilla citreola Pall. Tugcoryzka me.toro.romas.}

Желтоголовая трясогузка въ качествђ гнб̌здящейся птицы очень обыкновенна въ Барабинской степи, гд'ь близљ станціи Татарской вт, 1899 г, было добыто 4 экземпляра. Изъ окрестностей ст. Каинскъ я получиль отъ II. A. IILастовскаго 4 шкурки и кладку изъ пяти яичекъ. Въ Кулундинской степи эта трясогузка

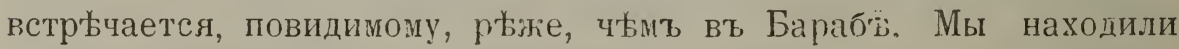
ее здъсь въ окрестностяхь дер. Плотниковой, близъ д. Чистоозерской и въ долинь Іртыша близъ стан. Семиярской.

Экземпляры коллекцій:

1) б ad. ет. Татарская $15 /$ r 99 r. 13,5 a. 80 c. 70 t, 22,5 шк.

2) $\mathrm{ad}$.

$15 /$ vI 99

14

74

6923

3) 우 $\mathrm{ad}$.

$17 /$ vi 99

12,5

ㄴ) t ad.

18 VI 99

14

5) ㅇ ad. д. Плотникова

13 vi 02

11

72

6922 ”

6) t $\mathrm{ad}$

$10 / \mathrm{r} \quad 03$

13

7) t ad.

$15 \mathrm{r} \quad 04$

13

8) ㅇ ad.

$16 r \quad 04$

13

79

7323,5 ,

9) t ad.

$17 \mathrm{r} 04$

13

75

6923 мум.

$\begin{array}{llll}80 & 72,5 & 23 & \text { шाн }\end{array}$

$797124 \quad$,

$\begin{array}{lll}75 & 66 & 23\end{array}$

$\begin{array}{lll}76 & 71 & 23\end{array}$ 
Полная кладка июъ пяти ненасиженныхъ яицъ была найдена 24.го мая 1902 г. Гньздо помьщалось на кочкь близь озера въ камынахъ въ 2 в. отъ ст. Каинскъ. Размьры и высъ яичекъ:

$$
\begin{aligned}
& \text { 1) } \frac{18,2 \times 13,5}{0,09} \text {; 2) } \frac{18,3 \times 13,2}{0,10} \text {; 3) } \frac{18,0 \times 13,4}{0,10} \text {; 4) } \frac{18,2 \times 13,0}{0,09} \\
& \text { и 5) } \frac{18,8 \times 13,5 \text { мм. }}{0,1 \text { гр. }}
\end{aligned}
$$

Finsch (стр. 175), не отличающий Mot. citreola Pall. отъ близкой горной формы Mot.citreoloides Hodgs. съ совершенно черной спиной, встрбчалъ желтоголовую трясогузку по тракту между Омскомъ и Семипалатинскомъ и получалъ экз. изъ окрестностей Омска оть Н. Я. С.юовцова, по которому (1897 стр. 143) въ Омскь она не составляетъ рбдкости и (стр. 255) „цовольно обыњновенна во всей Тобольской губерніи“, в’ь южной полюсъ которой найдена и $M$. Рузски.и (стр. 21). Приводится $A$. Норозовым (стр. 13), но почему-то не упоминается B. H. Лl.итниковыль (стр. 10) для оғрестностей поселка Ямышевскаго на Иртышъ.

\section{Motacilla flava campestris Pall. З желтолобаa тpscoryzra.}

Желтолобая трясогузка нами въ степях нашего края не добыта, но приводится M. Iузскимъ (стр. 23) для юга Тобольской rуб. въ качеств б̆ паселяющей камышевыя и тростниковыя заросли озерт, а . Н. Н.лотниково (стр. 10) сооппаетъ, что этоть видъ въ окрестностяхъ поселка Ямышевскаго встрьчается часто на лугахъ и на мочажинахъ близъ 03. Соляного. Такъ какъ имъ Mot. citreola не приводится вовсе, то у меня является подозрьніе. не относится ли часть его наблюденій надъ Mot. campestris къ жел. тоголовой трясогузкь, несомн'ьнно найденной на Иртышъ,

\section{Motacilla flava flava Limn. Tpseoryska желтяя.}

Типичная форма желтой трясогузки добыта нами въ К̌улундинской степи, гдь она встрьчается гораздо ръже свьтлоголовой (beema Sylies). Опредъленіе этихь экземпляров'ь провърено г-номь V. von Tschusi. 
Экземпляры коллекшій:

1) б ad с. Кілюевое 11 ri 02 r. 11 а 80 c. 71,5 t. 23 мун.

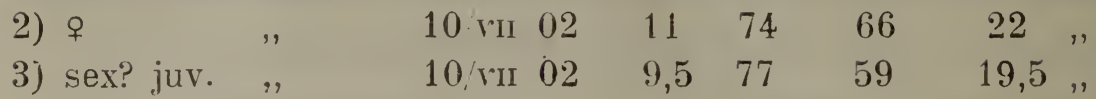

Большинство авторов'ь, занимающихся изсльдованіемъ западно-сибирскихъ птицъ, недостаточно точно опредьляютъ подвиды желтыхъ трясогузокъ. Поэтому нельзя судить о томъ. съ какими

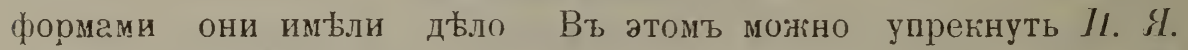

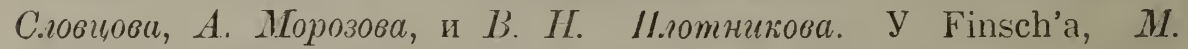
Рузскало и $B$. Біанки мы находимъ точныя указанія на попадавшіяся имъ формы желтыхъ трясогузокъ. Типичная flara найдена въ южной полпсь Тобольской губ. и эксшедиціею II. T. Нинатова въ Омскомъ и Кокчетавскомъ ућздахъ, равнымъ образоиъ приводится B. C Е.патиевспив (стр. 150)для Омскаго убзда.

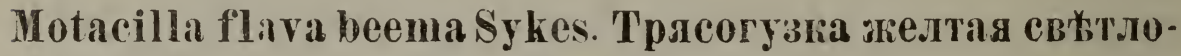 головая.}

Эта форма является наиболье распространенной въ степной части нашего края. Въ Барабинской степи она найдена в'ъ окр. станцій Убинской, Татарской, Коченева. Изъ окр. ст. Каинскъ мнб доставленъ II. А. ПІастовским одинъ экземпляръ. Экспедиція прпф. Н. $\Theta$. Каиелко 1900 г. добыла нысколько экземпляровъ близъ сель Убинскаго и Локоть. Во время побздки въ Кулундинскую етепь эта характерная для Западной Сибири птичка неоднократно наб́людалась близъ с. Камень на Оо́и, по сырымъ мћстамъ близъ дер. Плотниковой, въ степи между с. Тюменцевымъ и Вылковымъ, въ камышахъ въ окрестностяхъ дер. Чистоозерской, по р. Степному Кучуку, близъ села Ключевого (вмьсть съ Mot. flara flara Linn.). Найдена близъ Барнаула и въ сель Тулинскомъ на Оби.

Экземпляры коллекцій:

1) ᄒ ad. ст Татарская $27 /$ r 99 r. 13 а. 79 с. 66 t. 22,5 шк.

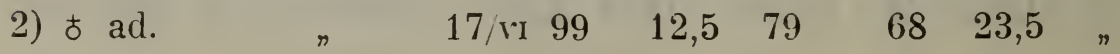

$\begin{array}{llllllll}3) & \text { ad. } \quad 15 / \mathrm{vl} & 99 & 13 & 76 & 66 & 22 & \text { " }\end{array}$

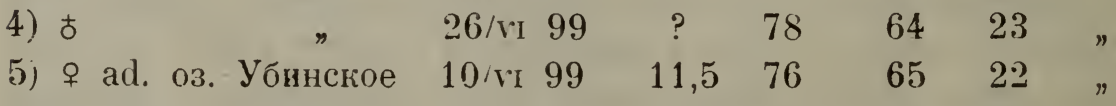

6) む ad. ет. Каинскъ 16, v $04 \quad 11,8 \quad 79 \quad 71 \quad 23$ ” 
7) ㅇ ad. с Уо́инские $26 /$ ฯ $00 \quad 12074 \quad 67 \quad 22$ шк.

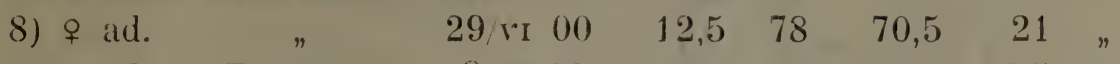

9) + ad. с. Локоть $\quad \mathrm{S} /$ ri $00 \quad 11,5 \quad 72 \quad 65 \quad 21,5$,

10) а ad. д. Плотникова $14 /$ г $02 \quad 12 \quad 76 \quad 65 \quad 21$ мум.

$\begin{array}{llllllllll}11) & \text { \& ad. } \quad 12 / \mathrm{rr} & 02 & 12 & 75 & 65 & 22 & \end{array}$

$12)+\quad$ ad. $12 / \mathrm{r} 02 \quad 11,5 \quad 75 \quad 68 \quad 21,5$ шк.

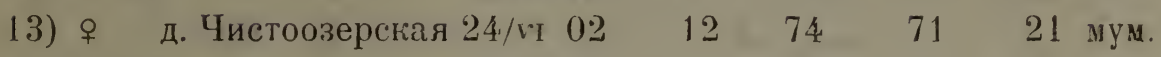

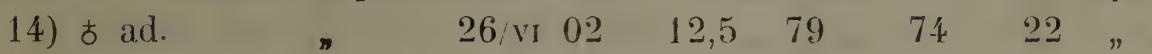

15) б ad.oкр. г. Барнаула 30 г $99 \quad 13 \quad 77 \quad 72 \quad 22$ шк.

$\begin{array}{lllllll}16) \text { t ad. } \quad 17 / \text { r } & 01 & 12 & 75 & 68 & 22\end{array}$

M. Д.. I'узскіи (стр. 16 и 28) нашель свьтлоголовую желтую трясогузку въ качествъ гнъздящейся птищы въ кустахъ рђчныхъ долинъ южной пюлосы Тобольской губерніи. Экспедиція Ииатова добыла вполн古 типичный экз. въ Омскомъ у. (См. В. Біанки стр. ј).

\section{Motacilla flava borealis Sund. Tpgcoryzka желтая темиого.товая.}

Область гнбздовья этой формы лежить сьвернъе области beema Sykes. На пролеть несомньнно посьщаеть степи нашего края. НҺкоторыя экземпляры съ болье темной головой сqитаю за переходные отъ beema къ borealis. Типичныхъ экземпляровъ этой формы вา, коллекціяхъ изъ степной части нашего края нбтъ: наиболье подходитъ къ этой формьь экземплярт изъ Барабы, измъренія котораго:

1) ᄒ ст. Татарская $26 /$ v 99 r. 12,5 а. 79 с. 71,5 t. 21,5 шк.

\section{Anthus trivialis Linn. Конежь, лисной заналиый.}

lіонекъ льсной въ западной формъ (восточная maculatus Hodgs. разъ была добыта мною въ окрестностяхъ Т'омска) очень обыкновенная гнъздящаяся птица во всъхъ степяхъ нашего края и встрбчается всюду, гдь есть льса, рощи или по крайней мърђ березовые колки. Убитый проф. Н. Ө. Кащенко 12-го іюня 1899 г. близъ станціи Убинской въ Барабъ экземплярь содержалъ яйцо, готовое къ сносу. Отъ II. A. IІастовскало я получилъ три яйца изъ кладки въ шесть сильно насиженныхъ яицъ, взятыхъ 21 го мая 1903 г. близъ ст. Каинскъ. Размъры этихъ трехъ яицъ выра- 
жаются однимъ, и тьй же числомъ $20,5 \times 15,0 ;$ в Бсъ двухъ изъ нихъ 0,14 гр., одного 0,15 гр.

Экземпляры коллекцій:

1) б ad. ст. Уӧинская 12/v 99 r. 13 а. 86 с. ? t. 20,5 шк.

๖) む ad. ст. Убинская $12 /$ VI $99 \quad 12 \quad 90 \quad 64 \quad 21 \quad$ n

3) 우 ad. ст. Уо́инская $12 /$ vi 99 $\begin{array}{llll}13 & 81 \quad 60,5 & 21\end{array}$

4) 우 ad. ст. Татарская $28 /$ VI 99 $13 \quad 83 \quad 60 \quad 20,5$

i) б ad. дер. Саушка

6) sex? ad. д. Плотникова

2/VI 00 $14 \quad 8873$ $20 \quad$

7) sex? ad. д. Плотникова $13 / \mathrm{VI}$ 13 VI 02 $10,3 \quad 83 \quad 60$ 20 мум.

8) sex? ad. п Плотникова $14 /$ VI 12 1

9) sex? ad. д. Плотникова $14 /$ VI 02

10) sex? ad, с. Вылково $\begin{array}{lll}17 / \text { VI } & 02 & 11,5\end{array}$ 8159 19 $11 \quad 85 \quad 60 \quad 20,5$ $8360,5 \quad 20,5$ 11) sex? ad. с. Вылково $17 /$ VI 02

$85-60$
$"$

Что касается особенностей окраски, то заньчу лишь, что у экз. ㅇ 9 вторыя рулевыя съ каждой стороны не имъютъ бұлаго вершиннаго клиновиднаго пятна на внутреннихъ опахалахъ. Эти пятна у другихъ экземпляровъ нашей коллекціи выражены хорошо, варіируя въ размьрахъ.

Въ прилегаюцихъ къ степнмъ Томскаго края мвстностяхъ найденъ близъ Омска И. С.лови,овымб и А. Морозовы.й, въ льсистой части Тобольской губ. Н. (.юовипвымб и М. Гузскиль, въ Акмолинскомъ уъздь экспедиціег II. I. Иинамова, въ Петропавловскомь и Кокчетавскомъ уьздахъ И. Я. (.ивиовымб (стр. 143). Странно, что A. Морозовг (стр. 13) приводитъ для окрестностей Омска изъ щеврицъ лишь только trivialis, не упоминая richarti и campestris, между тьюь какъ B. H. II.гомниковъ (стр. 10) пля окрестностей пос. Ямышевскаго приводить исключительно самpestris, не упоминая vichardi и trivialis. Въ окрестн. г. Барнаула этоть конекъ гнбздится во множеств'ь.

\section{5(i. Anthus richardi Vieillot. Honекx, crenнoй.}

Степной конекъ-характерная для степей нашего края птица и найленъ почти повсемъстно во время коллектированій. Изъ окрестн. станціи Каинскь и изъ окр. Барнаула я имью экземпляры огъ гг. ПI. А. ПІІастовскаго и А. П. Ве.иижанина 
Әкземпляры коллекцій:

1) a ad. ст. Уйинская $S$ vi 99 r. 16 a 95 с. 77 t. 32 шк.

2) o ad. ст. Татарская

3) + ad.

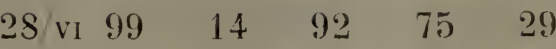

4) о аd. ст. Коченево

$29 /$ VI 99

15

90

$70 \quad 30$

30 , พI 99

1496

$7 \cdot 2$

30

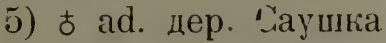

$1 / \mathrm{VI} 00$

13,5

97

80

30

(6) јшк. пос. Шульба

20 VI 00

15

85

72

27

7) sex. јuv. д. Н. Кучукъ

8) sex? juv. "

1175

50

3 VII 02

$10 \quad 70$

43

9) \& ad.

$\begin{array}{ll}5 / \text { VII } & 02 \\ 5 / \text { VII } & 02\end{array}$

$14 \quad 91$

75

24,5 мум.

10) sex? јиу.ст Семиярская $20 /$ vл 02

$13 \quad 82$

74

23

$25 \quad "$

11) sex? juv. "

$26 /$ VII 02

1286

23,5

12) sex? juv. "

26 VII 02

13

89

68

26

72

25

1386

70

$25 \quad "$

14) ad. окр. г. Барнаула 22 vш 98

$\begin{array}{lllll}14 & 98 & 84 & 31 & \text { шк }\end{array}$

15) $\subsetneq \mathrm{ad}$.

$4 /$ vII 99

13

89

79

16) ᄒ ad. ст. Каинскъ

$15 / \mathrm{v} \quad 04$

15

97

77

17) $ᄒ \mathrm{ad}$.

$17 / \mathrm{v} \quad 04$

15

92

$78 \quad 30,5$

$17 / \mathrm{v} \quad 04 \quad 13$

90

$78 \quad 30,5$

72

$28 \quad$

Первый экз., добытый проф̆. $H . \Theta$. Каищенко, отличается отз остальныхъ роговыми наростами на плюснахъ и частью на пальцахъ объихъ ногъ, расположенными довольно симметрично.

Весьма странно, что степной конећъ не приводится ни однимъ изъ нашихъ авторовъ (O. Finsch, H. Я. С.ловиовъ, А. Мо. розовг, В. Н. Шлотникрво и М. ДL. Рузскій). Экспелиція II. Г. Нинатова не добыла степного конька.

\section{Anthus campestris Linn. Конект полевой.}

Конекъ этотъ найденъ во многихъ мъстахъ нашихъ степей. Е'ь Барабинской степи близъ ст. Каинскъ, Убинской и Татар. ской эта птичка пока не добыта, но мъстами она встрбчается вдоль линіи Сибйрской ж. д. въ районб нашихъ изсльдованій, о чемъ свидъ̆тельствуетъ экз., добытый близъ ст. Коченево Въ Кулундинской степи мы находили этотъ-видъ по р. Степному Fучуку, близъ с. Ключевого; въ степяхъ Павлодарскаго у. әта птичка весьма обыкновенна. Въ окр. ст. Семиярской на Иртышъ этотъ конекъ вмбсть́ со степнымъ встрбчаются довольно часто. Экспе- 
диція проф $H . \Theta$. Кащенко доставила въ наш'ь музей әкземпляры этого вида изъ дер. Саушки и пос. Шульбы.

Экземпляры кольекцій:

\begin{tabular}{|c|c|c|c|c|c|}
\hline 1) t ан. ст. Коченево & 30 טי 99 & 15 & 89 & 69 & 25 \\
\hline 2) む ad. д. Саушка & 2 VI 00 & 12 & 82 & 51 & 25 \\
\hline 3) б ad. пос. ІІуульба & 20 VัI 00 & 13 & 88 & 71,5 & 25 \\
\hline 4) sex? & 20 vi 00 & 15 & 87 & 71 & 24,5 \\
\hline 5) sex? ad. с. В.лочевое & $11 /$ vin 02 & 14 & 85 & 67,5 & 25 мум. \\
\hline sex? ad ст. Семиярская & 27 vir 02 & 14,5 & 84 & 68 & 25 \\
\hline
\end{tabular}

Подъ Омскомъ полевой конекъ судя по Финиу, Морозов!; и (.овиову не найденъ. Въ южной полось Тобольской губ. найденъ М. Рузским'ь (стр. 11, 14, 16, 17 и 21). Экспедиціею ПI. Г. Нюнапова этотъ конекь найденъ въ Омскомъ, Кокчетавскомъ и Атбасарскомъ уу. (Біанки стр. 4). Въ первомъ изъ нихъ найденъ и B. C' L.лиатвевскимг (стр. 149). По B. H. 11.лотнипюву (стр. 10) въ степи близъ пос. Ямышевскаго на Иртышь встрђчается очень часто.

\section{- Anthus pratensis Linn. lonen' эуговой.}

О нахожденіи этого конька въ изсльлуемомъ районъ въ моемъ распоряженіи нбтт никакихъ фактическихъ доказательствъ. Найденъ $K$. М.. Дерюицныљъ на съверь Тобольской губ. (стр. 88). لо E. Harter'ty въ Западной Сибири цо долины Оби (стр. 276).

\section{Oriolus oriolus Linn. Иволга.}

Мбстн. назв.: „полевая кошечка“ (ст. Татарская), „соловєй“ (дер. Плотникова).

Въ Барабинской степи иволга найдена въ разныхъ мъстахъ. Крикъ ея я слышалъ въ березовой рощицъ 9-го іюня 99 г. близъ Убинскаго озера. Безуспьшно охотились за иволгой въ рощ близъ ст. Татарской. Въ Кулундинской степи иволга найдена въ дер. Плотниковой, с. Вылковъ, д. Чистоозерской, д. Нижній Кучукъ, с. Ключевомъ; она здъсь населяетъ хвойные лћса и березовыя рощи и колки въ степи. Экземпляры, доставленные въ нашъ музей экспедиціею проф. Н. $Ө$. Кащенко 1900 г. изъ приалтайскихъ степей, такъ же какъ и остальные, а равно экз. моей коллекціи, полученные отъ $A$. П. Ведижанина изъ скрестностей 
г. Барнаула, принадлежать къ обыкновенной форм' ивллги, зам бненной въ Туркестанъ уже широко распространенной на гнъздовьち въ южной Азіи формою Kundoo Sykes.

Экземпляры коллекціӥ:

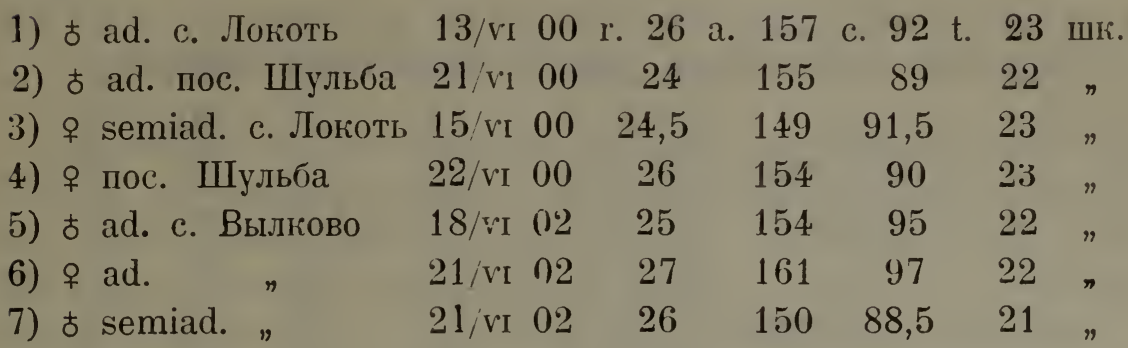

O. Finsch (стр. 187) видълъ въ коллекціи Словцова экземп. изъ окрестностей Омска, откуда приводится и $A$. Морозовынъ (стр. 11). Для южныхъ частей Тобольской губ. приводится $И$. Я. Словиовымг (стр. 254) и М. Д. Рузскимб (стр. 17 и 19). По В. Н. IІ.отникову (стр. 8) встрьчается довольно рбдко близъ пос. Ямышевскаго на Иртыш'. По И. Я. Словщову (стр. 144) иволга весьма обысновенна по всььъ березовымъ рощамъ около Омска, Петропавловска и въ Кокчетавском'ь уъздъ.

\section{Lanius minor Gmel. Чернолобый coporony'ть.}

Мъстн. назв.: „Сорочка“ (с. Кілючевое).

Въ степной части Томскаго края чернолобый сорокопутъ встрђчается чаще своихъ сородичей и, насколько мгжно судить на основаніи пока произведенныхъ наблюденій, замбняеть здьсь оольшого сорокопута (Lanius excubitor homeyeri Cab.), столь распространеннаго вь центральныхъ и восточныхъ частяхъ нашего обширнаго края. Въ Барабинской степи онъ, повидимому, встрбчается нъсколько рбже, чьиъ въ Кулундинской и приалтайскихъ степяхъ; добыты экземпяры близъ станціи Татарской, гдъ эти птички нерьдко усаживаются на телеграфныхъ проволокахъ. Отъ II. $A$. IIастовскало я получилъ экз. изъ окрестностей ст. Каинскъ. Въ Кулундинской степи и прилегающихъ мъстностяхъ Семипалатинской области онъ намъ попадался довольно часто. Мы находили его въ Кулундинскомъ бору у с. Вылкова, въ окрестностяхъ дер. Чистоозерской и Нижняго Кучука, въ Съверномъ бору у с. Блючевого и, наконецъ, по дорогъ отъ стан. Семиярской въ т. н. 
Ближній боръ. Степная экспепиція проф. Н. Ө. Кащенко 1900 г. тоже неоднократно находила этого сорокопута въ окр. с. Локоть, с. Бородулиха, пос. Шульба и с. Убинскаго.

Экземпляры коллекцій:

1) ᄒ ad. ст. Татарская 18 , r 99 r. 16 a. 119 c. 91 t. 27 шћ.

2) o ad.

$$
18 / \text { vi } 99
$$

15.5

122

3) 우 ad. с. Локоть $10 /$ r 100

15.5

117

96

27 "

4) $q$ ad. с. Боролулиха 18 ri 00

16

5) ᄒ аd. ст. Шульба

20 ir 00

16

6) 우 ad.

20 w 00

16

7) sех? jur. с. Убинское

$26 /$ Yi 00

11,5

8) б ad. с Вылково

$18 /$ I 02

15

9) tad.

$17 /$ r. 102

14,5

17 TI 02

14,5

117

90

$24 "$

10) sex? ad.

7 III $0: 2$

11) sех? јич. Д. Н. Кучукъ

$9 /$ r.II 02

12) ᄒ ad. о. Kisючевое

$\begin{array}{lll}9 / 1 & 02\end{array}$

13) sex? ad.

14) о ad. ст. Каинскљ

$11 / \mathrm{r} 03$

1

$119 \quad 92$

26

25

$114 \quad 88$

89

57

24

124

101

24

25

116

94

25

$117 \quad 93$

11

86

49

26 мум.

15

119

ІІри сравненіи экземпляровъ нашихъ сборовъ съ экземпляромъ западно-европейскаго процсхожденія, любезно доставленнымъ мнб B. $\Phi$ он ъ-Ч узи (Hallein. T. 87 г. о r. 14 а. 113 с. 88 t. 23 ) я никакой существенной разницы замьัтить не могъ.

П. С. П алласъ не указыраетъ на нахондденіе этого вида ( $\mathrm{L}$ rigil P a ll) въ Сибири. О. F in s c h (стр. 189)наблюдалъ этотъ видъ „25 Stationen hinter Omsk" и увъряетъ, что чернолобый сорокопутљ, ,bisher nicht aus Sibirien nachgewiesen“. Но уже въ 1845 г. Ф. Б р андтъ приводитъ этотъ видъ для Западной Сибири (стр. 443), а. кромь того М. Богдановъ (етр. 120) въ 1881 г. указываетъ на то, что этотъ сорокопутъ найденъ въ полось Западной Сибири между Ураломъ и Алтаемъ И. Я. С л о в о в ы м ъ, въ коллекціи котораго и $\mathrm{Finsch}$ видълъ экз. изъ окрестностей Омска. Здбсь найденъ и А. Мо розо вы м ъ (стр. 11) въ качествъ обычной, гнбиздящейся птицы, а въ Омскомъ уъздь В. С. Е л п а ть е в с к и м ъ (стр. 149). Въ Тюменскомъ округ бь по Слов цо в у (стр. 254) онъ встрьчается только изрьдка, въ Курганскомъ и Ишимскомъ уу. встрьчается чаще, в'ъ особенности въ Коктетавскихъ льсахъ (см. и И. Словцовъ стр. 1451897 г.). М. Д. Р уз ски м ъ (стр. 16, 17 и 30) 
найденъ въ березовыхъ рощцхх южной полосы Тобольской губ. Экспедиція П. Г. Игнатов а (стр. 5) добыла два экземпляра въ 70 в. къ югу отъ Омска. В. Н. ІІ лот н и к о в ъ (стр. 10) чернолобаго сорокопута для пос. Ямышевскаго не приводитъ. Въ окр. Барнаула по сообщенію А. П. Велижанина онъ гнђздится.

\section{- Lanius excubitor Limn. Coрогопуть больной.}

По мньнію М. Богдан о в а (стр. 135) на всем'ь пространств Сибири, до самыхъ западныхъ предъловъ ея не найдено никъмъ ни одного экземпляра настоящаго I. е х c u b itor. Не смотряна то, что эти слова были опубликованы нашимъ знаменитымъ орнитологомъ уже въ 1881 г., до настоящаго времени это названіе все еще примъняется для обозначенія большихъ сибирскихъ сорокопутовъ, изъ которыхъ въ Западной Сибири найдено ньсколько.

Такъ И. Я. С ло вц о в ъ (стр. 254) говсритъ о „L a n i us ex c ub i t or Li inn.", встрьчающемся гораздо чаще, чьмъ L. minor и colluri о. Подъ тьмъ же названіемъ приводитъ А. Морозовъ (стр. 11) большого сорокопута въ качествь довольно обыкновенной птицы для сбверной части Акмолинской области. В. Н. Плотниковъ (стр. 10), не упоминая вовсе чернолобаго сорокопута, говорить о „La nius ex cubitor Linn." изъ окрестностей пос. Ямышевскаго. Всъ эти указанія относятся къ L a nius excubitor major Pall. или же къ Lanius excubitor homeyeri Cab., изъ которыхъ въ Западной Сибири по моимъ наблюденіемъ второй встрьчается гораздо чаще перваго.

\section{- Lanius excubitor major Pall. Copokony'r больной cuбиperiil.}

(Lanius sibiricus Bogd.)

Въ нашихъ коллекціяхъ нбтъ экземпляровъ этого сорокопута изъ степной части Томскаго края.

\section{Lanius excubitor homeyeri Cab. Coporonyt' Bo- сточный.}

(Lanius leucopterus Ssew.)

Думаю, что часть, если не всћ приведенныя выше указанія о нахожденіи Is an. excubitor li in n. относятся именно къ во- 
сточному сорокопуту, который найденъ О. F in s c h'емъ (стр. 188) 16-го апрьля 1876 г. на Иртыпь близъ Семипалатинска. Въ нашихъ коллекціяхъ экземпляровъ нбтъ. Экземпляръ восточнаго сорокопута изъ окр. г. Барнаула, добытый 12 үш 1898 А. П. Вели жан и ным'b, болђе не сохраняется въ моей коллекціи, а переданъ В. фонъ Чузи. Гнъздо и лйца восточнаго сорокопута изъ окрестностей Тощка въ первый разъ описаны мною (ср. Ornith. Jahrb. 1900 стр. 28-34).

\section{Lanius collurio Linn. Coporonуть-жулапъ.}

Степная экспедиція проф. Н. $Ө$. К а щ е н к 1900 г. лоставила въ нашъ музей экземплярь из'ь дер. Саушки. Я получалъ экземпляры этого вида изт, с. Тулинскаго на Ооии и изъ окрестностей г. Барнаула.

Экземпляры кпллекцій:

1) ᄒ ad. с. Тулинское $18 /$ v 96 r. 13 а. 96 с. 81 t. 25 шк,

2) б juv. Барнаулт, 4, vu $98 \quad 13 \quad 96 \quad 82 \quad 24$.

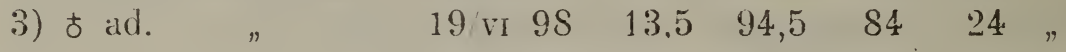

4.) t ad. " ? v1 $98 \quad 13.5 \quad 92 \quad 80,5 \quad 24 \quad$ "

5) t ad. " $\quad 4 /$ vш $98 \quad 14 \quad 94 \quad 84 \quad 25$,

6) $\delta$ ad. дер. Caymka 3, vi $00 \quad 14 \quad 97 \quad 80,5 \quad 23$ n

У әкземпляровъ № 4 и 6 имъются на крыльяхъ небольшія бълыя зеркальца. У экз. № 5 это зеркальце сравнительно велико. Со мньніемъ М. Богданова (стр. 70), что Семипалатинскъ и Алтай можно считать самымъ сђвернымъ мъстонахожденіекъ сорокопута-жулана въ Сибири, въ настояшее время нельзя согласиться, такъ какъ эта птица найдена не только въ Томскъ, гдъ встрбчаетея по монмъ наблюденіямъ вмъсть съ Lan. phoеn i curus Pall., но и въ Нарымскомъ крағ (В. П. Ан и ки н ъ стр. 165). По И. Я. С ло в І о в у (стр. 254) этотъ сорокопутъ гнҺздится въ Тюменскомъ и Туринскомъ убъздахъ. Найденъ М. Д. Р узс ки м (стр. 16,17 и 21) въ южной полось Тобольской губ. въ качествђ обитателя льсныхъ полянъ и опушекъ, березовыхъ рощъ и болотъ, поросшихъ кустиками низкорослой ивы и рБдкимъ, молодымъ березовымъ льсомъ. По А. Морозов у (стр. 11) этотъ сорокопутъ встрбчается подъ Омскомъ гораздо рбже чернолобаго и появляется по большей части осенью. В. С. Ел- 
па тьевскимъ (стр. 149) найденъ въ Ояскомъ у. въ льсныхъ островкахъ и въ колючихъ кустахъ Nitraria Schoeberi на пустынныхъ берегахъ озеръ. Въ Кокчетавскомъ уєздћ найденъ 11. Я. С ло в по о ым з (стр. 145).

\section{Lanius phoenicuroides Ssew. Дrучнарегій coporo- IYTt.}

По сообщенію А. Морозо в а (стр. 11) этотъ сорокопутъ ветрьчается подъ Омскомъ, но ръдко. ऊКаль, что при пшредъленіи не выясненъ и подвидъ. Другихъ указаній въ литературь ньтъ. Намъ во время побздокъ не попадался.

\section{- Lanius phoenicurus Pall. Сoporoпу'ъ рыжехвостый.}

Восточная граница области распространенія этого сорокопута проходитъ черезъ Томскъ, гдъ мною нбсколько разъ былъ гайдент.

\section{Ampelis garrulus Linn. Свиристель.}

$$
\text { (=Parus bombycilla Pall.) }
$$

Такь какъ свиристели появляются въ степяхъ нашего края осенью и зимою, а орнитологитескіе сборы производились льтомъ, то естественно, что этихъ птичекъ въ нашихъ коллекціяхъ ньтъ. Въ с. Ключевомъ мнђ описывали свиристелей такъ хорошо, что я не задумываюсь внести этотъ видъ въ число зимующихъ здЂсь. O. Finsch во время своего путешествія свиристелей видђль только въ Екатеринбургскомъ музеъ изъ окрестностей этого города (стр. 190). По И. Я. Словцов у (стр. 254) свиристели прилетаютъ въ окрестности Тюмени только на зиму большими стайками съ октября. По А. Морозов у (стр. 11) подъ Омскомъ свиристель встрбчается не часто, особенно осень. Въ окрестностяхъ пос. Ямышевскаго свиристели по В. Н. Плотникову (стр. 6) также появляются осенью, въ началь октября, въ льсахъ и рощахъ въ очень значительномъ количествъ. Въ 1907 г. П. А. Ш а с т о в скі й добылъ $22 \cdot$ го апрьля + близъ ст. Каинскъ; размъры ея: г. 11 а. 117 с. 66 t. 20. (частн. коллекція). 


\section{Muscicapa grisola Limn. Мухоловка сжрая.}

$$
\text { (= M. striata neumanni Poche) }
$$

Эта птичка, наиболье часто встрђчающаяся щредставительница мухоловокъ Томскаго края, найдена только въ Кулундинской стели въ окрестностяхъ д. Плотниковой въ степныхъ колкахъ и затьмъ въ рощицьь, состоящсй изъ березъ, сосенъ и осинъ близъ дер. Чистоозерской. Изъ окрестностей г. Барнаула я имью отъ А. П. В ели жа н и н а два экземпляра.

Экземпляры коллекцій:

1) б ad. огр. г. Барнаула 26/vn 99 r. 11 а. 84 c. 65 t. 14 шк.

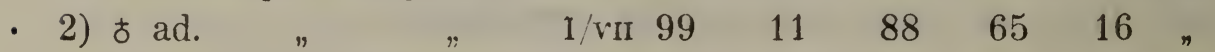
3) ad. sex? д. Плотникова $13 /$ ю $02 \quad 11,5 \quad 87,5 \quad 63,5 \quad 14$ мум. 4) ad. sex? д. Чистоозерск. 24/v $02 \quad 13 \quad 87 \quad 63 \quad 14,5$ "

Сравнивая добытые въ степной части нашего края экземпляры съ таковыми изъ южной Франціи и Буковины въ моей коллекціи, я существенныхъ различій подмбтить не могу.

Размьры их'ь:

5) ad. sex.? Южн. Франція 8/vi 91 (нов. ст.) r. 13 а. 87 с. 62 t. 14,5 шік. 6) ๖ ad. Буковина (Glitt) 10/ril $97 \quad$ " $12 \quad 85 \quad 62 \quad 15$ ”

Finsch (стр. 187) получиль отъ Сливцова экземпляръ изъ окрестностей Омска, ничбмъ не отличающійся отъ германскихъ. По И. Я. Словцову (стр. 254) сърая мухоловка гнъздится въ Тюменскомъ и Туринскомъ убздахъ, а также и въ Кокчетавскомъ (стр. 144). М. Д. Рузскій (стр. 17) приводитъ ее въ качеств'ь населяющей березовыя рощи юга Тобольской губ. Подъ Омскомъ сьрая мухоловка по А. Морозову (стр. 11) обычная форма. Упоминается для Омскаго уњзда и В. С. Елпатьевским (стр. 152). ПЈо В. Н. Плотникову (стр. 9) водится въ окрестностяхъ пос. Ямышевскаго въ изобиліи и гнбздуетъ нерьдко въ самомъ поселгь.

\section{Muscicapa atricapilla atricapilla Linn. Мухоловка- нежтрушиа.}

Во время нашихъ поъздокъ мухоловка-пеструшка въ степяхъ не добыта, но она безъ сомнънія принадлежитъ къ гнбздящимся птицамъ района нашихъ изслћдованій, такъ как'ъ, съ одной сто- 


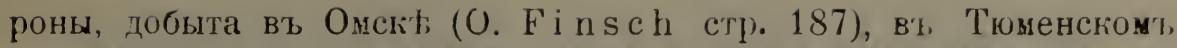
и Туринскомъ уъздахъ Тобольской губ., причемъ она въ южныхъ ућздах ъ Тобольской губ. обыкновенна (И. Я. Словцов'ь стр. 253), ст, другой же стороны-найдена подь Томском's, А. П. В елижан иным ъ и мною, а громь того добыта в'ь 1907 г. П.А. U а с т о в с к и м б близъ ст. Каинскъ.

Привожу здђсь измъренія сибирскихъ экземпляровъ моей коллекціи въ сравненіи съ экз. изъ Туниса, любезно предоставленным', мнъ моимъ другомъ V. von Tschusi.

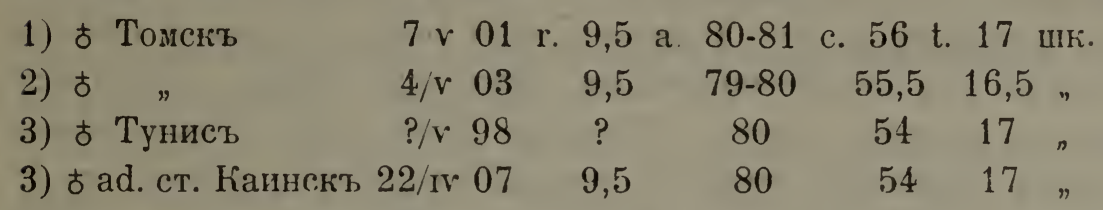

Наблюденія С. А. Бутурлина 1902 г. надъ окраскою рулевыхъ лифляндскихъ экземпляровъ этого вида - я могу подтвердить. Одинъ томскій экз. имъетъ на правпй сторонь хвоста на двухъ рулевыхъ, а на львой сторонь на трехъ рулевыхъ бълыя пятна; эта несимметричнссть еще болье поражаеть на экз. африканскаго происхожденія, у котораго съ правой стороны только два руле выхъ, а съ львой даже четыре рулевыхъ имьютъ бълыя пятна. У барабинскаго әкз. третье съ края рулевое каждой стороны снабжено бълым'ь пятномъ на наружной каймЂ, недоходящим'ь до вершины пера, какъ и на первомъ и второмъ.

\section{Chelidonaria urbica Linn. Jacточkа городская.}

О. F ins ch (стр. 152) въ коллекціи И. Я. С лов о в а видъл' экземпляры изъ оюрестностей Омска, вполнь тождествественные, по его мньнію, съ европейскими. Самъ И. Я. Словцов ъ не приводитъ городской ласточки для Тюменскаго у., равнымъ образомъ не упоминаетъ ее для южной полосы Тобольской губ. и М. Д. Рузскій. По А. Морозову (стр. 13) этоть видъ встрьчается однако всюду въ Акмолинской обл. и Тобольской губ., причемъ въ городахъ гнъздитея очень рьдко. Въ коллекціи II. Г. Игнатова изъ Акмолинской обл. по Біанки экз этой ласточки нбтъ, не приводитъ ее для пос. Ямышевскаго и В. Н. Ш лотников ъ. ІІо И. С ловцов у (1897 стр. 140) гнъздится въ Омскомъ и ПІетропавловскомъ убздахъ. Въ нашихъ коллекціяхъ экземпляровъ этого вида изъ степной чавти Томскаго края ньть. 


\section{Clivicola riparia Linn. Ласточка береговая.}

Эта почти космополитическая птичка на ст. Убинской и Татарской въ Бараб нами не была найдена. Въ окрестностяхт станціи Калачинской, гдъ протекаетъ р. Омь, мы нашли цблую колонію. По Оби и по Иртышу мы всюду находили значительныя колоніи ихъ. Въ Кулундинской степи мы нашли береговкхъ ласточекъ близъ дер. Плотниковой надъ озерами. Въ возвышающемся мьстами едва на два метра надъ уровнемь воды въ сзерь песчаномъ берегь Горькаго озера близъ названной деревни я нашелъ ихъ немногочисленныя гнъздовыя норки. Гнбздится береговая ласточка и по р. Степному Кучуку, гдъ добыта мною. Въ почти безводной степи, по которой пролегаетъ дорога отъ с. Ключевого на Павлодаръ, в’ предълахъ Павлодарскаго у. береговая ласточка устраиваетъ свои норки въ стЂнкахъ колодцевъ, выкопанныхъ по дорогь⿱㇒㠯 Проф. Н. Ө. Каще н к о найдена въ д. Саушк'.

Экземпляръ коллекціи:

1) sex? ad. д. Нижній-Кучукъ $6 /$ vi 02 r. 6,5 a. 108 с. 57 t. 11 мум.

O. Finsch (cтp. 151) всюду въ предълахъ нашего края находиль этихъ ластпчекъ. По И. Я. Словцо ву (стр. 253) и М Р уз ском у (стр. 27) она весьма обыкновенна въ Тобольской губ. На Иртышь найдена В. Н. ІІ лотниковым (стр. 5), на Иртыш' и Оми кромь того А. Морозовым ъ (стр. 13). В. Л Біанки (стр. 7), изсльдовавшій 5 экземпляровъ, добытыхъ экспедиціею П. Г. Игна то ва на озерь Сабынды-Куль въ Акмолинскомъ у., сообщаетъ, что всь относятся къ типичной темной формь, а не къ C. diluta Sharpe. И. Я. Словцовымъ (стр. 140) въ Кокчетавскомъ у. не найдена.

\section{Hirundo rustica rustica Linn. Ласточки деревенская западиая.}

Ласточка деревенская въ Каинскомъ у. вездђ очень обыкновенна. Тоже относится къ населеннымъ мьстамъ по Оби и Иртышу и къ селеніямъ въ Кулундинской и приалтайской степяхъ. Изъ Барнаула въ моей коллекціи. 
Экземпляры коллекцій:

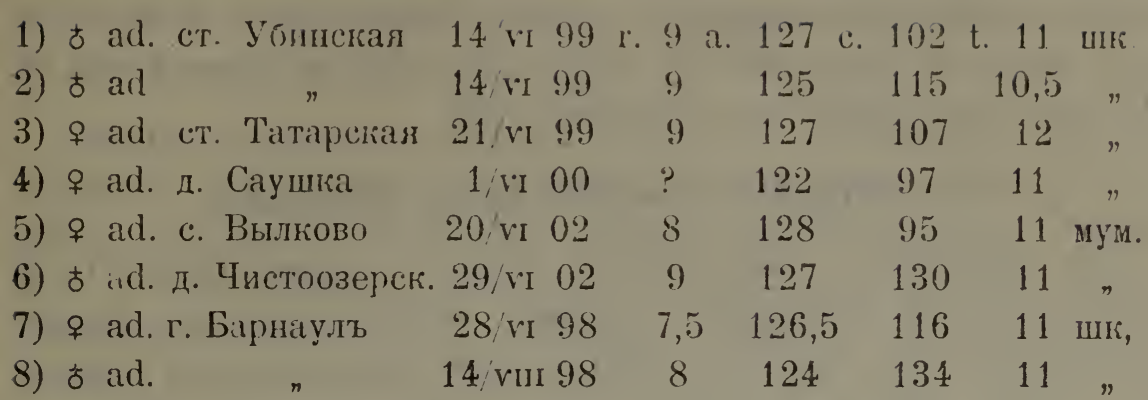

По литературнымъ данныжъ эта ласточка встрьчается всюду въ разсматриваемой мъстности.

Изъ дер. Саушки проф. Н. Ө. К а пе е ко вечеромъ 5-го іюня 1905 съьздиль на берегъ Колывань-озера, гдъ досталт гньздо деревенской ласточки съ пятью сильно насиженными яйцами. Гнъздо помбщалось на скаль, надъ водой, на нижней поверхности нависшей надъ водой скалы. Размьры лицъ:

1) $20,2 \times 14,3$ мм.; 2) $20,0 \times 14,3$ мм.; 3) $20,0 \times 14,0$ мм.;

4) $20,0 \times 14,0$ мм., и 5) $20,0 \times 14,3$ мм.

\section{Coccothraustes coccothraustes Linn. Дубонос'ь.}

(C. vulgaris Pall.)

Во время побздокъ дубоносъ не добытъ. У III ренка (стр. 301) нахожу указаніе, что въ Зоологическомъ Музеь Имп. Академіи Наукъ хранятся экземпляры дубоноса изъ окрестностей Барнаула. По сообщенію А. П. Вели жан ин а дубоносъ подъ Барнауломъ гнъздится часто. Около Тюмени по И. Я. Словц ов у (стр. 252) онъ очень ръдокъ. У другихъ авторовъ указаній нътъ. Подъ Томскомъ встрьчается часто, въ особенности въ январь и февраль, но не ежегодно.

\section{\%0. Fringilla montifringilla Linn. I0рокт.}

Юрокъ принадлежитъ къ гньздящимся въ льсной части нашего края птицам'ъ. Въ коллекціяхъ экземпляровъ нътъ. Степи посьщаются имъ, въроятно, лишь во время пролета. По И. Я. Словцову (стр. 251) онъ пролетаетъ черезъ Тюменскій у. большими стайками. М. Д. Рузскій не приводитъ его цля 
южной полосы Тобольской губ. По А. Морозов у (стр. 14) онъ однако найденъ въ хвойныхъ льсахъ южной части Тобольской губ., а по И. Словцову (1897 стр. 147) въ началь мая въ 50 верст. отъ Омска въ сосновомъ льсу.

\section{Fringilla coelebs Linn. 3ıб.лиเъ.}

По сообщенію прив.-доцента нашего универси'гета П. Н. Крылова ему приходилось слышать пбніе зяблика въ университетской рощь, а льтомъ 1905 г. и въ окрестностяхъ Томска. гды весною 1906 г. П. А. Ш астов скому удалось добыть б и найти гнбздо. Другихъ указаній на нахожденіе зяблика въ предълахъ Томскаго края пока нбтт. О. F in s ch (стр. 205) получилъ отъ И. Я. С ловцов а экземпляръ изъ окрестностей Омска, не отличимый отъ европейскихъ. По Сло в ц в у (стр. 251) зябликъ распространенъ во всей средней и съверной части Тобольской губерніи, но подъ Смскомъ встрбчается только во время перелетовъ. М. Д. Рузскій (стр. 16, 17 и 19) указываетъ на зяблика какъ на обитателя березовыхъ льссовъ и рощъ и сосновыхъ боровъ кжной полосы Тобольской губ. Очень интересна зальтка А. Морозова (стр. 14), что зябликъ встрбчается „всюду въ Омскомъ и Петропавловск. у., Тюкалинскомъ и Каинскомъ округахъ“. Чтп касается посльдняго, то могу лишь указать на то, qто во время моего пребыванія въ Барабинской степи мнъ ни разу не приходилось слышать характерное, хорошо мнь изв ьстное пьніе зяблика. Въ коллекціяхъ изъ степной области экземпляровъ ньтъ. Въ хвойныхъ льсахъ Кокчетавскаго убзда зябликъ по Словцо в у (1897 стр. 146) отсутствует"ь.

\section{э2. Carduelis carduelis major Tacz. Пеголь занадно- сиборскій.}

В1. Барабинской степи нами добытъ близъ ст. Убинской въ канавъ около жельзнодорожнаго полотна. Нъсколько разъ щеглы здъсь были замбчены и сидящими на телеграфной проволокъ. Въ окрестностяхъ г. Каинска щеглы довольно обыкновенны. Любители ихт держать въ кльткахъ. Въ сосновыхъ борахъ Кулундинской степи щеглы также встрычаются. Въ станиц' Семиярской въ окнь одного дома я замбтилъ щегла въ кльткъ. По справкамъ оказалось, что онъ пойманъ здђсь зимою, когда ихъ бываеть много 
Экземпляры коллекцій:

1) \& ad. ст. Убинская $9 /$ vi 99 r. ? a. 81 c. 55 t. 14 шк.

2) б? ad. с. Вылково 17/vi $02 \quad 13 \quad 84 \quad 55 \quad 16$ мум.

Второй экземплярт, интересенъ въ том'ъ отношеніи, что представ.ляеть помъсь между обыкновеннымъ щегломт, и алтайским'ъ. (Card. card. major Tacz. $\times$ Card. caniceps orientalis Eversm.). Подобныя помьси нербдко встрбчаются зимою и въ Томскь, гды у птицелововъ извьстны подъ названіями „князекъ“ и ,березовикъ “.

O. Finsch (стр. 205) видбл' щегловъ изт окрестностей Омска въ коллекціи Словцова, по которому (стр. 253) щеглы живутъ круглый годъ въ Тюменскомъ, Ялуторовскомъ и Ишимскомъ убздахъ. Въ южной полпсь Тобольской губ. щеглы найдены М. Руз ски и ъ (стр. 17) въ березовыхъ рощахъ. Іо И. Словцову (1897 стр. 147) и А. Морозо ву (стр. 14) щеголь"встрбчается всюду въ Омскомъ и Іетропавловскомъ у., тасто большими стайками. Въ окрестностяхъ пос. Ямышевскаго на Иртышђ В. Н. II лотников ъ (стр. 11) находиль щегловъ довольно рбдко въ таловыхъ и тополевыхъ рощахъ, а также по дикимъ коноплянникамъ.

Странно, что А. Миддендорфь въ „Jsipiptesen“ (стр. 37) приводить щегла для Барнаула Въ качествђ пролетной птицы, указывая на сроки его появленія, когда щеголь въ Барнауль, какъ и въ Томскь несомньнно осьдлая птица.

\section{Carduelis caniceps orientalis Eversm. Cъцоголовый пценол\%.$$
\text { ( = Passer carduelis var. Pall ) }
$$

Насколько область гнбздовья этого щегла затрагиваетъ степи нашего края-неизвбстно, такъ какь во время побздокъ здъсь типичные экземпляры сбдоголоваго щегла не добыты. У П. С. Палласа (стр. 15) нахожу указаніе на нахожденіе сбдоголовыхъ щегловъ в'ь Барабинской степи.

\section{Chrysomitris spinus Linn. Тижт.}

Между тьмъ какъ П. С. Палласомъ (стр. 16) ирямо отрицается нахожденіе чижа въ Сибири словами „ultra Uralense jugum nullibi nbservata“, в` настоящее время извъстьо его спора- 
дическое гнбъдованіе по всему съверу Азіи. Изъ этихъ данныхъ насъ здъсь интересуютъ соопщенія И. Я. С ловцова (стр. 252) и А. Морозова (стр. 14), по которымъ чижь встрбчается въ Тобольскомъ уъздъ, между тьмъ какъ отсутствуетъ въ Тюменскомъ. Шодъ Омскомъ чижъ встрьчается, но рьдко. Такъ какъ чижи иногда появляются въ ТомскБ (см. мои замбтки въ „Ornith. Jahrb " 1899 , p. 126 и 1904, p. 85), то весьма въроятно, что они жъстами водятся и въ Барабъ.

\section{Acanthis cannabina fringillirostris Bp. et Schleg. Коноплянка восточная.}

В. ЛI. Біанки (стр. 2) въ коллекпіи П. Г. Игнатова нашел'ь экземпляръ этой коноплянки изъ Атб́асарскаго у. Вполнђ убъжденный въ правильности опредъленія я не задумываюсь отнести къ восточной формы наблюденія И. Я. С ло в ц о в а (стр. 251), по которыиъ рбполовы встрбчаются въ Тюменскомъ и Курганскомъ у., а также и сообщеніе А. Морозова (стр. 14), что коноплянка въ Омскомъ у. встрбчена у киргизскихъ зимовокъ. Безъ всякаго сомньнія сюда же должно быть отнесено сообщеніе В. Н. Пло тнико в а (стр. 11), что коноплянка гнъздится близъ пос. Ямышевскаго. Всб перечисленные авторы кромъ В. Біанки приводять коноплянку подъ названіемъ западной формы. Нами въ степяхъ Томскаго края не найдена.

\section{Acanthis flammea flammea Linn. Чечетьа обыкно- венная}

\section{и \%. Acanthis hornemannii exilipes Coues. Чечетка свьтлая.}

По разсказамъ мЕстныхъ жителей зимою какъ въ с. Кіючевомъ, такъ и на станиць Семиярской чечетки встрђчаются въ значительныхъ стайкахъ. Въ литератүрь (Словцовъ, Морозовъ, Плотниковъ) указывается лишь на одинъ видъ, но изъ разсказовъ жителей, какъ изъ томскихъ наблюденій несомнбнно явствуетъ, что мы имъемъ цъло съ двумя формами чечетокъ, зимующихъ на всемъ протяженіи нашего края. Если къ сопбщенію И. Я. Словцова (стр. 251) о томъ, что чечетки и льтомт встрбчаются въ Тюменскомъ и Туринскомъ у., хотя и гораздо ръже чьмъ зимою, можно отнестись съ полныиъ довьріемъ, то 
ирайне сомнительнымъ, мнђ юажется сообщеніе В. Н. Плотникова (стр. 11), что чечетка „гнбздуетъ во всьхъ окрестныхъ перель. скахъ поселка (Ямышевскаго). Врядъ ли чечетки гнђздятся такъ далеко на югъ въ равнинъ!-Изъ окрестностей Барнаула я получиль әкземпляры, добытые въ хплодное время года. Вт окрестностяхъ Томска въ 1906 г. чечетки найдены гнбздящимися.

\section{Passer domesticus Linn. Воробей домашиій.}

Всюду обыкновенная осьдлая птица въ. деревняхъ.

Экземплярь коллегціи:

1) ᄒ ad. ст. Калачинская 25/vi 99 r. 13 a. 80 c. 60 t. 15 шик.

По И. Я. Словцову (стр. 147) и В. С. Елпатьевскому (стр. 149) воробєй проникъ въ глубину степей въ 40-хъ годахъ прошлаго стольтія, сльдуя за русскимъ населеніемъ.

\section{Passer montanus Linn. Воробей полевой.}

Въ Барабинской степи, а также и въ Кулундинской, полевой воробей въ нькоторыхъ селеніяхъ встрььчется чуть ли не чаще своего „домашняго“ сородича. Ньсколько разъ попадался намь въ колкахъ въ безлюдной степи.

Экземпляры коллекцій:

1) \& ad. ст. Убинская $12 /$ vi 99 r. 12 a. 69,5 c. 57,5 t. 18 шк. 2 Isex? ad. ст. Татарская $16 /$ vi $99 \quad 11 \quad 72 \quad 57 \quad 17$ " 3) sex? juv. \# $\quad 17 /$ vi $99 \quad 10,5 \quad 70,5 \quad 53 \quad 18$ \# 4) sех? ad. с. Вылково 21/vi $02 \quad 11 \quad 71 \quad 57 \quad 20$ мум.

\section{Carpodacus erythrinus Pall. Чечевичнпк'}

Чечевица весьма распространенная в'ъ степяхъ нашего края птичка. Въ Барабинской степи она найдена близъ Каинска П. А. Шастовским въ качествь гнбздящейся. Во время пођздки 1902 г. ее нашли въ березовыхъ колкахь близъ дер. Плотниковой и затбмъ въ окрестностяхъ ст. Семиярской на Иртышъ. Въ открытыхъ безльсныхъ мыстностяхъ она отсутствуетъ. Изъ окрестностей г. Барнаула въ моей коллекціи нъсколько экземпляровъ отъ А. П. В ели жк анин, одинъ изъ с. Тулин- 
скаго оть г. Иаркова. Экспедиція проф. Н. Ө. Кащенко добыла чечевищу близъ с. Локтевскаго, пьніе ея профессоръ слышалъ близъ дер. Саушки.

Экземпляры коллекціи:

1) $q$ ad. с. Тулинское $20 /$ v 96 r. 10,5 а. 83 c. 61 t. 20 шк.

2) ᄒ semiad. г. Барнауль 14/vi $98 \quad 10 \quad 83,5 \quad 56 \quad 19$ ”

$\begin{array}{llllllll}3) \text { t ad. } \quad \text { 14/vi } 98 & 10 & 84 & 60 & 19 & \end{array}$

4) ᄒ ad. $\quad$ n $30 /$ vi $98 \quad 10 \quad 82 \quad 60 \quad 19,5 \ldots$

5) ad. с. Локоть $9 /$ vi $00 \quad 11 \quad 82 \quad 61 \quad 18 ”$

6) ᄒ semiad. д. Шлотникова $12 /$ ri $02 \quad 11 \quad 81 \quad 57 \quad 19$.

7) ad. ст. Семиярская $20 /$ vII $02 \quad 10 \quad 82 \quad 57 \quad 20$ мум.

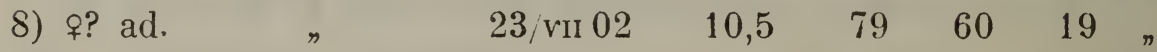

O. F in s c h (стр. 212) сообцаетъ по наблюденіямъ И. Словцова (стр. 147) срокъ прилета чечевичника въ Омскь, гдъ найдент и А. Морозовым т (стр. 14).

Въ Акмолинскомъ у. найденъ әкспедиціею П. Г. Игнатова (см. Біанки стр. 3). По В. С. Елпатьевскому (стр. 148) въ Омскомъ у. очень распространенная птичка. И. Я. Словцов ъ (стр. 147) нашелъ чечевичника по Ишиму и около Имантавской станицы.

\section{? Loxia pytyopsittacus Borkh. liлесть-cocnoвик'ь.}

Клесты къ фаунғ степей какъ обитатели хвойныхт льссовъ принадлежать не могутъ, и нами даже въ сосновыхъ борахъ Кулундинской степи не найдены. По оюраинамъ разсматриваемаго райюна клесты встрбчаются в'ь качествь кочуюшихъ птицъ, и литературныя указанія не лишены интереса. И. Я. Слов І о в т (1897 стр. 148) сообщаетъ, что "Loxia pythiopsittacus Bechs“ убитъ около Омска 17-го августа 1879 г. Это указаніе повторяется и А. М о р о зо в ы м ъ (стр. 14), добавившимъ, что клестъ-сосновикъ встрьчается и „въ еловых" льсахъ Тобольской губ.". Во всей доступной мнь литератур' вообще нбтъ другихъ указаній на нахожденіе этого именно вида на востокъ оть Урала, если не считать, „nomen nudum“ у F. B randt'a (стр. 441). Если опредъленіе безошибочнюе, въ чемъ я нъсколько сомньваюсь, то вопросъ - восточной границ Б области распространенія этого свойственнаго области Балтійскаго моря клеста далеко еще не выясненъ. 


\section{Loxia curvirostra Linn. liлect'-еловнк'}

О нахожденіи әтого чрезвычайно распространеннаго въ сьверной Азіи клеста в'ь интересующей насьь мъстности имђется лишь сообщеніе И. Я. Словцова (стр. 250), что онъ разъ быль убить въ конць феераля огсло Тюмени и 17-го марта 1878 г. 古 и $q$ около Омска. А. Морозовъ (стр. 15) кромь того сообщаетъ, что этоть клесть указанъ г. С о ти иковым ъ „въ сосновомъ бору у ст. Чернолуцкий и изрбдка попадается у птичниковъ “. Въ нашихъ коллекціяхъ экземпляровъ нътъ.

\section{Loxia leucoptera elegans Hom. Іілестьь бълокрылый.}

Одно лишь сообщеніе И. Я. Словцова (стр. 250), что три экземпляра этого вида убиты зъ октябрь 1888 г. въ окрестностяхт Тюмени. Другихъ указаній на нахонденіе этого красиваго клеста ньтъ.

\section{Pyrrhula pyrihula pyrrhula Linn. Cnбоирь лрасно- брюхій большой.}

$$
\text { ( = P. coccinea Selys-Longch.; P. major Brehm.) }
$$

Мъстн. назв.: „жуланъ“ (повсем встно въ Томской губ.); „жуланчикъ (с. Ключевое).

Снбгирь этотъ гнъздится въ Кулундинскозъ бору близъ с. Вылкова. Здъсь во время нашего пребыванія (16-ое по 22-ое іюня) довольно часто приходилось видбть въ бору снбгирей. Добытый мною здъсь 古 имъетъ на крайнихъ рулевыхъ ясно выраженныя бълыя полосы („Cassini'sche Streifen“), между тъм' какъ у здъсь же добытой, онь отсутютвуютъ. По разсказамъ появляется въ большомъ числь особей зимою близъ с. Ключевого и другихъ населенныхъ пунктьвъ нашего района. П. А. Ш а сто в ски мъ найденъ близъ ст. Каинскъ.

Экзехпляры коллекцій:

1) ad. с. Вылково $17 /$ ri 02 r. 10,5 а. 92 с. 73 t. 19 мум.

2) 우 $\mathrm{ad}$, $\quad 17 / \mathrm{vi} 02 \quad 11 \quad 91 \quad 70,5 \quad 17$.

O. Finsch (cтp. 212) видьлъ въ коллекціи И. Я. Словцова (см. 1897 стр 147) экземпляры изъ окрестностей Омска. По Словцов у (стр. 251) въ Тюменскомъ округь сньгири появля- 
ются только зимою; льтомъ здъсь разъ только была доғыта старая я. По сообщенію этого автора въ южныхъ округахъ Тобольской губерніи снбгирей можно встрбтить въ теченіе всей зимы. $\mathrm{Bъ}$ Омскь они по С ло в ц о в у отлетаютъ въ началь марта. Съ этими указаніями вполнб согласуется отсутствіе снбгирей въ южной полось Тобольской губ. по М. Р у з с к о м у, посьтившему әту мъстность льтомъ. А. Мо о озовъ (стр. 14) однако круглый годъ находилъ снбгирей въ окрестностяхъ Омска. В. Н Плотн и ко въ приводитъ „снигиря-жулана" для окрестностей поселка Ямышевскаго въ качеств в всрьчаюцейся по лугамъ, преимущественно въ таловыхъ рощахъ, и совершенно отсутствующей въ степи птички. Из' его словъ не видно, гнъздится ли снбгирь по Иртышу.

\section{Pyrrhula cassini Baird. Снъгирь сърый сибирскій.}

(P. cineracea $\mathrm{Cab}$.)

Зимюю стайки этого гнбздящагося въ Восточной Сибири снъгиря соединяются с'ь предшествующимъ видомъ в'ь смьшанныя стайки и кочують по странь, передвигаясь иногда и значительно на вапацъ. Во время такихъ кочевокъ сърый снбгирь посьшаетъ и степи нашего края. П. А. Ш а с т о в к і й поймалъ 16-го февраля 1903 г. близъ ст. Каинскъ одинъ экземпляръ этого вида изъ стайки обыкновенныхъ снбгирей и любезно доставилъ мнъ его живымъ. Даю измьренія ньсколькихъ экземпляровъ воей коллекціи:

1) окр. г. Томска 19/xi 02 r. 9,5 а. 87 с. 76 t. 18 шк.

$\begin{array}{lllllllll}2) \text { t } \quad \text { n } & 19 / \text { xil } & 02 & 9 & 85 & 73 & 19 & \text { n }\end{array}$

3) \% $\quad 28 / \mathrm{x} \quad 05 \quad 10 \quad 88 \quad 71,5 \quad 17 \quad$ "

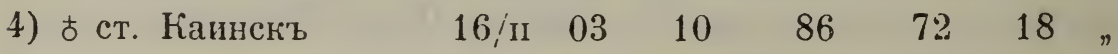

Наружное опахало самаго внутренняго изъ маховыхт. праваго крыла одного изъ томскихъ экземпляровъ моей коллекціи окрашено въ красный цвътъ, у одного экземпляра этой формы съ Амура, выписаннаго мноюдля сравненія отъ фирмы W. Schl üt e r в’ь Halle, я замътиль эту аномалію на львомъ крыль. Такимъ образомъ оказывается, что слова L. Taczanowski (p. 683)

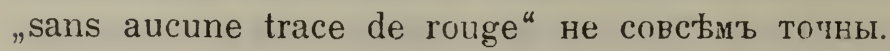


Въ литературб не нахожу указаній на нахожденіе въ степной 'хасти нашего края этого интереснаго сньгиря, часто принимаемаго за фо обыкновеннаго вида.

\section{Pinicola enucleator Linn. Щуръ.}

Щуръ появляется въ изсльдуемомъ районъ, какъ обитатель хвойнаго л'са, только исключительно случайно, во время кочевокъ. Такъ И. Я. С ло в ц въ (стр. 250) сообщаетъ, что щуръ изрьлка появляется около Тюмени осенью и зимою; только въ 1889 г., начиная съ декабря. появилось ихъ необыкновенно много. Ему въ эту зиму доставляли щуровъ изъ Тгоменскаго, Ишимскаго и даже Курганскаго у. Другихъ указаній въ литературъ H'bT'b.

\section{Uragus sibiricus Pall. Снъгирь долгохвостый.}

Экспедиція проф. Н. Ө. Каше еко 1900 г. добнла этихъ красивыхъ снбгирей, характерныхъ для Сибири, въ двухъ экземплярах'ь на озерғы въ 8 в. отъ с. Локоть. Въ Кулундинской и Барабинской степяхъ пока не найдены.

Экземпляры коллекціи:

1) む ad. с. Локтевское $9 / \mathrm{vi} 00$ r. 9 a. 73 c. 90 t. ? шк.

2) ᄒ ad. " $9 /$ ri $00 \quad 10 \quad 72 \quad 83 \quad 16$ "

$\mathrm{Bz}$ литературб о нашихъ степяхъ, почему-то нбтъ указаній на нахожіденіе этой птички, столь обыкнивенной подъ Томскомъ.

\section{s\%. Emberiza pyrrhuloides Pall. Овсянка толстоклювяя.}

Экспедипія П. Г. Иг на т ов а добыла толстоклювую овсянку въ 4 экземплярахъ въ Акмолинскомъ и Атбасарскомъ убздахъ. В. А. Бі н ки (стр. 3), опредълившій ихъ, не указываетъ на subspecies. Принадлежатъ, быть можетъь, къь неназванному подвиду; приводимому Е. Hartert’oмъ (стр. 199) подъ № 320. Въ нашихъ коллекціяхъ толстоклювыхъ овсянокъ нб̆ъъ.

\section{Emberiza schoeniclus Linn. Tростниковый воробей.}

Вљроятно, гнбздится во всей Барабъ. Изъ другихъ частей нашихт степей пока свьдьній ньтъ. Отъ П. А. ШІ астов ск аго я 
получиль два красявыхъ, покрытыхъ характернымъ рисункомъ, яичка этой овсянки изь окрестностей ст. Каинскъ. Гньздо помьшалось посреди болота на высокой кочкь и 25-го мая 19() 2 г. въ немъ находилось 5 сильно насиженныхъ яичекъ. Отъ того же коллектора я получилғ кладку изъ пяти васиженныхъ яицъ, взятую имъ 21-го мая 1903 г. близъ ст. Каинскъ. Измьренія и вьсъ яицъ:

$$
\begin{aligned}
& \text { 1) } \frac{20.0 \times 14,6}{0,13} \text {; 2) } \frac{19,7 \times 14,5}{0,13} \text {; 3) } \frac{19,0 \times 14,3}{0,13} \text {; 4) } \frac{18,2 \times 14,3}{?} \text {; } \\
& \text { 5) } \left.\frac{18,0 \times 14,0}{0,12} \text {; 6) } \frac{19,5 \times 14,5}{0,13} \text { и } 7\right) \frac{16,5(!) \times 13,3 \text { мм. }}{0,11 \text { гр. }}
\end{aligned}
$$

Четвертое яичко недостаточно промыто (его въсъ 0,24). Седьмое яичко отъ остальныхъ значительно отличается размєрами и формою; оно значительно меньше и круглье другихъ.

Въ коллекціи проф. В. В. Сапожникова два экземпляра, добытые на Иртышь во время пролета:

1) ᄒ ad. ст. Лебяжья $9 / \mathrm{iv} 1902$ r. 10 а. 82 c. 71 t. 19 шк.

2)

Верхняя сторона очень свђтлая. Матеріала для сравненія у меня нбтъ, а потому не рбшаюсь үтверждать, что экземпляры принадлежатъ къ недавно описанному E. Hartert'oмъ (стр. 197) новому подвиду Emb. s choeniclus pallidior, одинъ экземпляръ котораго (изъ окрестностей Омска) хранится въ Британскомъ музеъ.

O. Finsch (cтр. 217) находилъ тростниковаго воробья на Иртышъ. По И. Я. Сло вцов у (стр. 250) онъ распространенъ во всей Тобольской губ. (до устьевъ р. Оби), въ южной полосъ которой найденъ и М. Д. Рузским и (стр. 23). А. Морозовъ (стр. 15) приводитъ нашу птичку, кромь того и для Акмолин. ской области, гдь подъ Омскомъ, въ Петропавловскомъ и Кокчетавскомъ убздахъ найдена С ло в ц о вым (1897 стр. 147).

О полноть списка птицъ В. Н. П ло тн и ко в а для окрестностей поселка Ямышевскаго на Иртышь можно судить на основаніи полнаго отсутствія представителей рода Emberiza. 


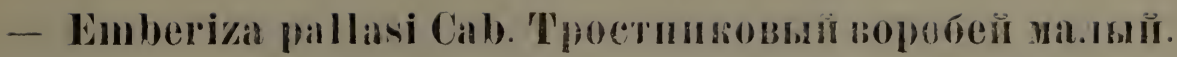

(Emb. schoeniclus $\beta$. Pall =Emb. polaris Midd.)

Ресьма вьроятио, что эта овсяниа постщлетъ степи нашего края на пролеть, такъ какь найдена на пролеть вь ндкоторыхъ частяхт, Тургестана, а кромб того почти ежегодно наблюдается на пролетахъ и подъ Томскомъ.

\section{Kmberiza (itrinella Limm. 0велmа желтонаночна:}

Эта овсянка в’ь степной части нашего края не только гнъздящаяся птичка, но и зимующая. Къ осьдлымт әкземплярамъ на зиму присоединяются несомнънно и особи изъ солће сьверныхъ мьстностей. такь какъ џисло особей, остающихся зимовать, напр. въ окрестностяхъ Томска, значительно уменьшается, мелду тыль какъ число ихъ въ окреєтностяхъ Барнаула и другихъ полье южныхъ мъстностяхъ на зиму увеличивается. Въ моей коллекніи экземпляръ изъ окрестностей ст. Каинскъ отъ П. А. Шастовскаго.

Его измьренія:

1) б ad. ст. Каинскъ $15 / \mathrm{r} 04$ r. 10 а. 92,5 с. 72 t. 19.5 шк.

E. Hartert (стр. 169) считаеть запано-сибирскихъ желтопапочныхъ овсяникъ за подвидъ erythrogenys Brehm. Не имья возможности сравнить здьшнихъ, овсянокъ сь западно-европейскими за отсутствіеиъ матеріала, я оставляю вопрост о подвиды пока открытымъ. Съ размьрами крыла, цанными Е. Hartert'oмъ (58-63 мм. для Emb. citrinella citrinella Linn. и $6:-64$ для Emberiza citrinella erythrogenys Brehm еา, Алтяя), врядъ ли можно согласиться: измбренные мною экземпляры гораздо крупнбе.

O. Finsch (стр. 214) видБлъ в’ь коллекціи И. Я. С л о в ц о в а экземпляры нзъ окрестностей Омска. Въ Алиолинской огіл. и То больской губ эта ивсянка всюду гнћздится пе А. ИІ орозову, И. Я. Слпвцов у и М. Д. Р узскому.

\section{Emberiza Lortulana Linu. Oвcяmia caдoвas.}

Садовая овсянка широк') распространена на гнбзздовь Б̈ въ Алтайс:ихъ горахт и въ степяхъ Томскаго края. Экспедиция проф. К а щ ен к о 1900 г. достави.та въ нашъ музей экземпляръ 
изъ дер. Саушки. Отъ своихъ коллекторовъ я получаль изъ Барнаульскаго убзда әкземпляры. Во время пюъздки по Кулундинской степи мы ее неоднократно находили. Она здъсь населяетъ такія же мъста, какъ и Pratincola maura, и часто усаживается на высокихъ, травянистыхъ растеніяхъ въ открытой степи. Въ Барабинской степи вдоль полотна желъзной дороги пока не найдена.

\section{Экземпляры коллекцій:}

1) t ad. дер. Саушка 2,vi 00 r. 10 a. 86 c. 70 t. 17,5 пк.

2) ᄒ ad. с Тулинск. на Оби $7 /$ г $96 \quad 9,5 \quad 87 \quad 72,5 \quad 19 \quad$ "

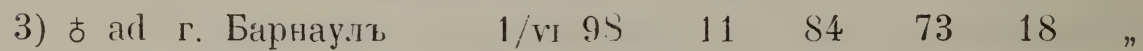

4) б ad. с. Вылково $\quad 18$ vг $02 \quad 11 \quad 89 \quad 72,5 \quad 20$ мум.

$\begin{array}{llllllll}5) \text { t } \mathrm{ad} . & \quad 18 / \mathrm{Vl} & 02 & 11 & 87 & 72,5 & 19 & \\ 6) & 21 / \mathrm{VI} & 02 & 11 & 85 & 66 & 18 & \end{array}$

Отъ К. А. С а ту иин а поступила въ мою коллекцію шкурка этой пвсянки съ Кавказа изъ окрестностей Тифлиса. Ни по окраскъ, ни по величин в́ сио̆ирскія особи не отличаются оть кавказскихъ, насколько можно судить на основаніи столь небольшого матеріал: для срэвненія.

Странно, что E. Hartert'y (стр. 181) не извъстны м'ъстонахожденія нашей овсянки изт, Западной Сибири. Здђсь упомяну лишь јказанія, имъющія отношеніе къ нашимъ степямъ.

O. Fins ch (стр. 214) наблюдаль эту овсянку между Салаиромъ и Томскомъ и получилт, экъ. изъ окрестностей Омска отъ. И. С ло вц о в а (см. 1897 стр. 147). И. Я. С л о вц о в ь не приводитъ ее для Тобольской губ., между тьия какъ она здъсь найдена по Иртышскимъ склонамъ М. Д. Р уз ски м ь (стр. 14), а по А. М орозову (стр. 15). кромъ Тобольской губ́. всодү гнъздится и въ Акмолинской области.

\section{Emberiza lustica Pall. Orcunia-nenez'}

Во время пођздокъ эта овсянка намъ не попадалась, но регулярно постщаетъ пролетомъ нашт край, гдъ повидимому не гнђздится, хотя А. Морозовъ (стр. 15) и причисляетъ ее къ гнЊздящимся птицамъ, Тибольской губ. и Акмолинской области, что, вђроятно, справедливо лишь относительно сђверныхъ частей первой. O. Finsch (стр. 216) получиль отъ И. Я. Словцова эк- 
земпляръ изъ окрестностей Омска (см. Словцовъ 1897 стр. 148 ). И. Я. Словцовъ (стр. 250) сообщаетъ, что этотъ видъ убитъ между Курганомъ и Іетропавловскомъ $3 \cdot$ го апрьля 1877 г. Около Тонска ежегодно пролетають эти овсянки масслми вь срединь апрғля, осеннее ихъ появленіе менъе замбтно (кохецъ августа и начало сентября).

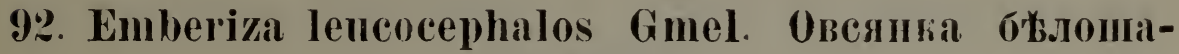 почная.}

(Emb. pithỵornus Pall.)

Бђлюшапочная овсянка очень обыкновенная, гнђздящаяся атичка въ сосновомъ льсу („рямь“) близъ ст. Убинской въ Барабъ. Тамъ жке она населяетъ и березовыя рощицы въ степи. Самка, добытая зльсь 12 к 99 , содержала близкія къ сносу яйца, причемъ брюхо было почти совершенно лишено перьевъ. Мы находили эту характерную для Сибири гтичку и въ другихт мьстахъ Барабы, а. из' окрестностей ст. Каинскъ я получилъ экзеипляръ оть П. А. III а с то в скаг о, а также и яичко ея. Во время пођздки по Кулундинской степи мы нашли эту пвсянку въ качествЂ гнъздящейся птицы въ Кулундинскомъ бору близъ с. Вылкова. Подъ Барнауломъ гньвдится. Экспедиціею проф. В. В. Сап ож и и ко в а добыта между Омскомъ и Павлоларомъ.

Экземпляры коллекцій:

1) ᄒ ad. ст. Убинская 12/rг 99 r. 12 a. 90 с 80,5 t. 20 шк.

$\begin{array}{llllllll}\text { 2) } & \text { o ad. } \quad * \quad 14 / \text { vi } 99 & 12 & 90 & 79 & 19 & \end{array}$

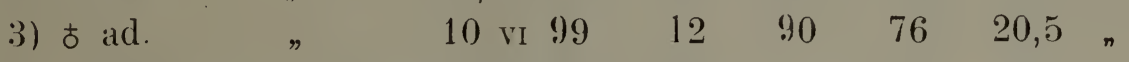

4) t ad. $\quad 8$ гi $99 \quad 12 \quad$ ? $77 \quad 20$,

$\begin{array}{lllllll}5) & \text { t ad. } \quad 10 & 99 & 12 & 92 & 81 & 20\end{array}$

6) 우 ad " $\quad 12 /$ vi $99 \quad 12 \quad 87 \quad 76,5 \quad 19,5 \quad$ "

7) ᄒ аd. с. Вылково 17 vi $02 \quad 11 \quad 89 \quad 78 \quad 21$ мум.

$\begin{array}{llllllll}8) & \# \quad 17 / \text { vi } & 02 & 12 & 82 & 68 & 20,5 & \text { " }\end{array}$

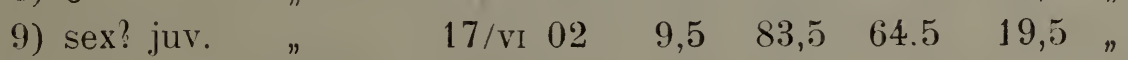

10) б ad ст Каинскъ $15 / \mathrm{v} \quad 04 \quad 12 \quad 91 \quad 77 \quad 19$ шк.

11) + ad. Омскъ-Павлод. 6 Iv $02 \quad 12 \quad 90 \quad 81 \quad$ i9

Эта характерная для Сибири птичка O. Fınsch'y (cтp. 215) попалась лишь разъ во время его путешествія близ'ь Марка-куля. По И. Я. Сло вцов у (стр. 250) бЊлюшапочная овсянка тоже 
щнш, разъ уо́ита оголо Тюмени. Весьна странно, 'тто 1. II о р озовт (стр 15) вовсе не упомишаеть этой овсянки для Акмолинской обл. и Тобольской губ́; въ южной полось посльдней она найдена М. Рузским ъ (стр. 20 и 29 ) въ качествъ обитательницы болотистых' пространствъ, поросшихъ тальниками и рьднимъ жолодымъ березовымъ льспмъ. Размћры и в беъ одного яичка этой овсянки изъ окрестностей ст. Каинскъ оть 28/v 07 равняютея 21, ј) $\times 15,7$ мм. и 0,16 гр.

\section{9:3 Emberiza calandra Limn. Opesmatimpocghta.}

(Emb. miliaria Linn.)

Обт, этой овсянкљ уже П. С. П алла ст (стр. 35) говоритъ "in Sibiria non datur et est frigidiorum regionum impatiens". Но әкземплары этого вида по мньнію проф. М. А Менибира (стр 54-2) залетають случайно изъ сњверо-западнаюо Туркестана въ юго-западную Сибирь, „но только случайно“. Эти слова относятся, повидимому, къ экз. коллекціи И. Я. Словцов а (см. 1897 стр. 148) изъ окрестностей Омска, которую пересмотрћлъ

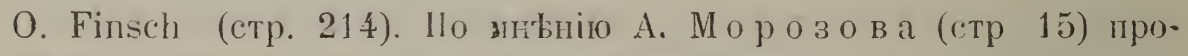
сянка однако вмысть сь другими овсянками въ Акмолинской обл. и Тобольской губ. не только гнъздитея, но и встрђчается всюду. Въ виду уғазаннасо разногласія и отсутствія другихъ литературныхъ данныхь желательпа провћрка наблюденій А. 11 ор оз ов а. Въ ншихъ коллекціяхъ экземпляровъ изъ степной части нашего гірал н'Ттъ.

\section{Emberiza luteola Sparm. Obrsma mesquas.}

(Emb. icterica Eversm, =Emb. brunniceps .J. F. Brandt.)

ЗҒелчная овсянга, гиъздящаяся -въ Закаспійскомъ грађ, Афганистань и Туркестань, мъстами гнтздится и въ степяхъ югозападной Сио́ири. Въ степяхъ нашего грая она пока найдена только әкспедишіею проф. Н. Ө. К а щ е н к 1900 г., доставившей въ нашъ музей әкземпляръ.

Его размьры:

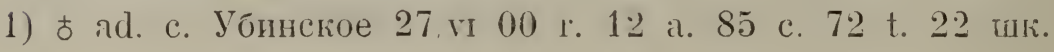


O. Finsch (стр. 2217) пашель этү овсянку 3 vi 76 на сыверномъ склопь Алтая. У Слов пова, Р узскаго, Моровова, Плотников а и Біанки указаній на нахожденіе желчной овслнки нбтъ.

\section{Emberiza aureola Pall. Дубровиик's.}

Дубровникъ весьма распространенная на гнъздовь' въ раз. сматриваемомъ районь птичка. Въ Барабинской степи она населяетъ березовые, осиновые и тальниковые колки и найдена нами въ окрестностяхъ ст. Убинской и Татарской. Изъ окрестностей ст Каинскъ у меня цҺлый рядт экземпляровъ отъ П. А. II а стсвскаго. Незатьйливие пьніе этой овсянки, широко распространенной на гнбздовь' в'ь долинахт, Оби и ея притоковъ, мы слышали близъ с. Спиринд и с. Камень. Вмбсть съ чечевичникомъ дубровникт, гнъззлится въ березовыхъ и тальниковыхъ колкахъ въ Кулундинской степи, гдъ мы находили его близъ. дер. Плотниковой, Чистоозерской и др., въ особенности недалеко отъ воды. Его присутствіе удалось констатировать и въ окрестн. ст. Семиярской, Семипалатинской области, в долинь р. Иртыша. Въ приалтайскихъ степяхъ найденъ проф. Н. $\Theta$. Ка щен по (дер. Саушка).

Экземпляры коллекцій:
1) а ad. ст. Татарская
15/VI $99 \mathrm{r}$
r. 12,5
a. $80 \mathrm{c}$
c. 65 t. 20.5 шк.
2) $\delta: a d$. $28 /$ vi 99
12
76
$63,5 \quad 20,5 \quad$.
3) $t$ ad.
29 VI 99
12
4) $\delta$ ad.
15 vi 99
13
5) $ᄒ$ semiad. ст Убинск. 12 vi 99
13,5
6) t semiad.
$12 /$ VI $99 \quad 1^{\prime}, 5$
78
80
58
21.5
7) $q$
ст. Татарская
15 VI 99
11
8) ㅇ
26. vi 99
11
9) ㅇ
$29 / \mathrm{vI} 99$
11,5
10) ㅇ дер. Саушка
$3 \mathrm{~V}: 00 \quad 11$
11) б ad. г. Барнауль
$15 / \mathrm{VI} 01 \quad 12$
12) ᄒ аd. д. Чистоозерск. 24/v1 02
12
13) б ad. ст. Семиялская $19 /$ vi 02
11
14) б semiad. ст. Каинскъ $14 / r 04$

11
15) $\delta$ ad
$15 / \mathrm{r} \quad 04 \quad 11.3$
16)

$\begin{array}{cccc}" & 15 / \mathrm{v} & 04 & 11.3 \\ " & 16 \mathrm{v} & 04 & 11\end{array}$
78
63,520 "
6320,5 ,
6220 "
$76 \quad 63 \quad 20,5$,
$75 \quad 59 \quad 20,5 \quad$ "
$7458 \quad 21$ "
$69.554 \quad 19 \quad$ "
$76.5 \quad 59,5 \quad 20,5 \quad$
$\begin{array}{lll}78 & 62,5 & 21.5 \text { мум }\end{array}$
$77,5 \quad 60 \quad 20 \quad$ ”
$73 \quad 60,5 \quad 20 \quad$ шк.

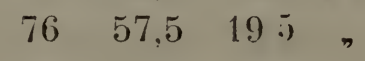

$\begin{array}{llll}70 & 53 & 19 \quad\end{array}$




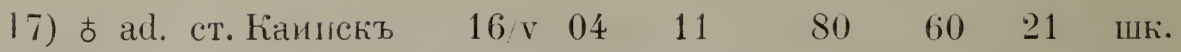

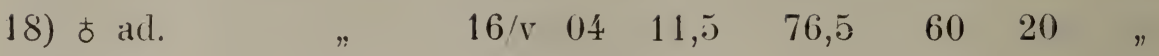

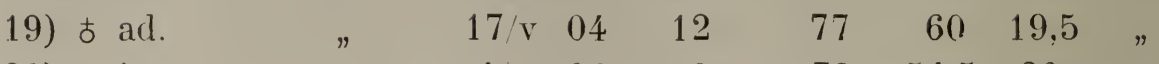
20) ᄒ juv. $\quad$ 4/vil $04 \quad 9 \quad 72 \quad 54,5 \quad 20 \quad$ n

O. Finsch (стр. 217) наблюдалъ золотистую овсянку близъ Колыванскаго завода и между Салаиромъ и Томскомъ. Отъ И Я. С ло в ц о в а онъ получилъ экз. изъ окрестностей Омска. Во всей средней и южной полось Тобольской губ. эта овсянка найдена И. Я. С лов цо вым ъ (стр. 250) и М. Д. Р уз ски и ъ (етр. 20, 21, 27 и 29). ПІо А. Морозов у (стр. 15) гнђздится въ Акмолинской области, въ Кокчетавскомъ убздъ которой найдека И. Я. Словцовымъ (1897 стр. 148).

\section{Calcarius lapponica Linn. Нодорожник' лапланд- скій.}

Лапландскій подорожникъ въ степной части нашего края най. денъ въ качествь зимующей и пролетной птицы, быть можетъ окаж:ется и гнбздящимся. П. А. Ш а стовскі й доставилъ мн字 шкурки этой птички изъ окрестностей ст. Каинскъ, гды онъ видълъ ихъ въ первой половинь' мая 1903 и 1906 г. не только большими стаями въ 50-100 штукъ, но поднималт, и отдћльныя пары. Весною 1904 г. ему также пришлось побывать на этой станціи и здћсь онъ съ 27-го по 29-ое марта опять вицћлт большія стаи этихъ подорсінников'ь.

Экспедиція проф. В. В: С а по ж九 ник о в а 1902 года цоставила въ натшь мүзей иять шкурокт этого подорожнцка, дойытыхъ мекду Омскомъ и Семипалатинскомъ.
1) б arl. ст. Лебяніья
$9 / \mathrm{IV} 02$ r. 11 a. 95 c. 66 t. $20 \mathrm{m \kappa}$.
2) ᄒ аd. ст. Ямышевская
$9 /$ IV 02
$10,5 \quad 92$
6820,5 ,
3) б Павлод -Семииалатинскъ $9 / \mathrm{v} 02$
$10.5 \quad 89$
$65,520,5$,
4) $t$ a
$9 /$ IV 02
$11,5 \quad 96$
69
$9 /$ IV 02
$11 \quad 89$
62195
5) o ad. " "
$10 . \mathrm{v} \quad 03$
1193
$66,5 \quad 20$
7) $t$ ad.
$7 / \mathrm{v} \quad 06$
$11 \quad 92$
6321 n

По сообщенію ІІ. С. ПІ а лл а с а этотъ подорожникь большими стаями пролетаетъ въь первой половинь апрғля по Исетскимъ и Ишимскимъ степямъ. 14 апрбля 1876 г. А ль рр едъ Брәмъ, 
членъ Брэменской экспедипіи, убилъ экземпляръ этого вида изъ стайки бълокрылыхъ жаворонковъ въ степи по Иртышу южнЊе Омска (О. Finsch стр. 220). ІІо И. Я. С.л овцову (стр. 249 и 148 ) лапландскій подорожник'ь встржчается вт, Тюменскомт увздъ рбже сльдующаго вида и убитъ только $24 / \mathrm{Iv}, 3 / \mathrm{v}$ 7S г. и $12 /$ IV 87 г.

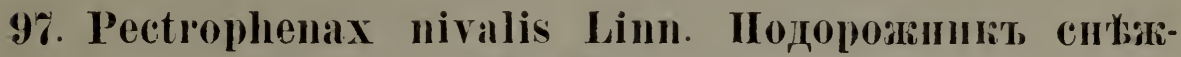 ный. II уночlia.}

Шуночка несомнбнно зимуетъ въ нашихъ степяхъ. Въ с. Ключевомъ мнъ описывали этихъ птичек'ь такъ хорошо, что я не задумываюсь внести ихъ въ списокъ зимующихъ. Экземпляровъ въ коллекціяхъ нбтъ. Литературныхъ указаній (O. linsch. стр. $220)$, И. Я. Словцов в (стр. 148 и 249) и А. Морозов (стр. 15) для Омска. Тюмени и Петропавловскаго у.) немного.

\section{Alauda arvensis arvensis Linn. अंаворонокт по- левой.}

На основаніи вамьтки В. Л. Б і анки о восточно-палеарктическихъ формахъ рода Alauda западно-сибирскіе полевые жаворонки должны быть отнесены къ подвиду arvensis Linn.

Полевой жаворонокъ одна изъ обыкновеннбйшихъ гнъздящихся птицъ нашихъ степей. Всђ университетскія коллекціи содержатъ экземпляры, моими помощниками мнъ были кром' того доставлены экземпллры изъ с. Тулинскаго, Барнаула и Каинска.

Эквемпляры коллекцій:

1) ᄒ аd. ст. Татарская 15 vi 99 r. 14 a. 111 с. 72 t 22 шк.

2) $\& \mathrm{ad}$

17 VI $99 \quad 14 \quad 103$

6523 "

3) $t$ ad.

$17 /$ vi 99

14

116

75

24

4) o ad.

$18, \mathrm{v}: 99 \quad 14$

119

79

23,5

5) $t$ ad.

26 vi 99

13

113

67

6) $t$ ad.

2S/vi 99

13,5

111

23

7) ad. ст. Калачинская 25/vi 99

14

118

7423 "

8) sex? ad.

$25 /$ vi 99

14

111

74

23,5

9) б јuv. ст. Коченево

$4 /$ VII 99

11

10) ј juv. д. Саушка

$4 / \mathrm{VI} \quad 00$

97

(1) sex? ad. с. Вылково

18 vi 02

9

$67_{\text {око.10 }} 20 \quad 22,5$ "

$13 \quad 114 \quad 76 \quad 24$ мум. 
12) sех? ad. с. Вылково $19 /$ г $02014 \quad 116 \quad 74 \quad 24$ мум.

13) б аd. д. Ниянн. Нуучукъ 2 vі $02 \quad 13 \quad 110 \quad 75 \quad 23$ шк.

14) sex? juv. " 2 уіл $02 \quad 11 \quad 94,5 \quad 54 \quad 24$ мум.

15) sex. juv. л. Шемюлина 5 vi $02 \quad 12 \quad 107 \quad 68 \quad 24$ ”

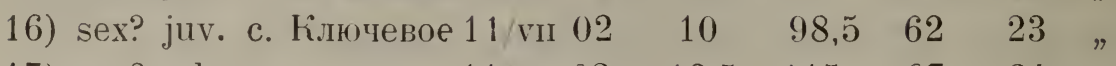

17) se.x? ad. " 11 vil $02 \quad 12,5 \quad 115 \quad 67 \quad 24$ "

18) б ad. с. Тулинское 13 vi $96 \quad 12,5 \quad 114,5 \quad 73,5 \quad 24,5$ "

19) sex? juv. г. Барнауль 26 кш $98 \quad 11 \quad 105 \quad 75 \quad 24$ "

20 ) $\begin{array}{llllllll}2 & \text { vid. } 01 & 13 & 112,5 & 76 & 23 & \end{array}$

21) б ad. ст. Каинскъ $15 / \mathrm{v} \quad 04 \quad 12,5 \quad 113,5 \quad 71 \quad 245$ n

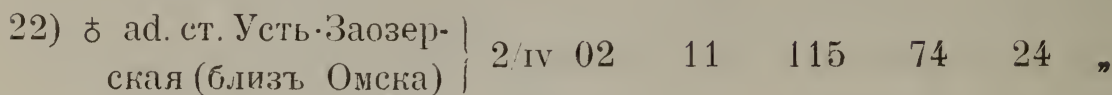

O. Finsch (стр. 221) изсльдовалъ экземиляръ, полученный изъ окрестностей Омска. Пь его мнђнію, пъніе сибирскихъ, жаворонковъ ничб̆мъ не отличается отъ пьнія германскихъ. По И. Я. Сл ов ц о у (стр. 247) полевой жаворонокъ встрбчается во всей средней и южной части Тобольской губ. М. Д. Рузскій (стр. 11) приводитъ егп пля степей Тобольской губ. Подъ Омскомъ на пгь по Иртышу найденъ, въ Петропавловскомъ и Кокчетавсһомъ у. рьдокь по сиобшеніямъ И. Слов дов а (стр. 148) и А. Мо розов а (стр. 14). Экспедиція П. Г. И г натов а (Бі анки стр. 3) добыла полевыхъ жаворонковъ типичной формы въ Акмолинскомъ и Кокчетавскомъ убздахъ, В. С. Елп п ть ев скій (стр. 148) вт Омском'ь у бздъ. Еъ окрестностяхъ пос. Ямышевскаго на Иртыш' по В. Н. ІІ ло тникову (стр. 10) встрђчается въ счень большомъ количеств'.

\section{Calandrella minor Cab. subsp? Жаворопок' сырый.}

(Calandrella pispoletta Pall. et auctorum.)

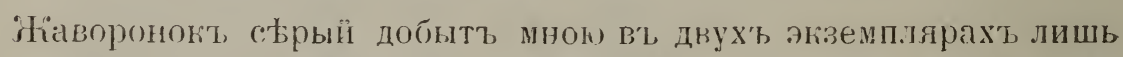
па львомь берегу Ијтыша в’ь степи близ', ст. Семиярской. Отсутствіе матеріала для сравненія не позволяет’ в’ь точности опредъ̌лить полвидт. Веслма вЈроятно, что это “al. minor seebolimi Sharpe.

Экземпляры коллегціи:

1) sех? ст. Семиярская 26 vir 02 l. 10,5 а. 84 с. ? t. 19 мум.

2) ᄒ. $\quad \# \quad 26$ viा $03 \quad 11 \quad 83.5 \quad 56.5 \quad 30 \quad$ шк. 
0. I'insch находилъ әтого жаворонка южнtе Семипалатинска. Другихъ указаній нътъ.

\section{Calandrella brachydactyla longipennis Eversm. жаворонок'ь малый.}

Добыть лишь энсшедиціею проф). В. В. Сапо жн и ко в а 1902 г. межлу Павлодаром'ь и Семипалатинскомъ. Измғренія:

1) ․ с. ІІодпускъ 10 ir 02 r. 11 а. 88 с. 57 t. 19,5 шк.

Въ литературь также мало указаній, какъ и о предыдущемт видь.

\section{Melanocorypha sibirica Gmel. bулокры.лый жаво- р0НОК'b.}

(Alauda leucoptera Pall.)

Уже П. С. ІІ аллас ъ (стр. 518), говоря о распространеніи әтого жаворонка, указываетъ на Барабинскую стешь, отъ р. Оми до Алтайскихъ горъ по всему теченію Иртыпа, какъ на ибстность, гдъ онъ встрбчается во множествђ. О. F. in s ch (стр. 223) часто встрьчалъ бьлокрылыхь жавоконковъ 14-го и 15-го апрьля между Омскомъ и Семипалатинскомъ и получиль отъ И. С ловцов а. (ср. 1897 стр. 148) экземпляръ изъ окрестностей Омска, гдъ А. Морозовъ самъ, повицимому, ихъ не наблюдаль (стр. 14). Экепедиція П Г. Игнатова (Біанки стр. 3) добыла цълый ряд’ әкземпляровъ этого вида въ Акмолинскомъ и Кокчетавскомъ у.

Во время пођздки по Кулундинской степи мы впервые замътили бълокрылаго жалоронка близъ с. Ключевого (Барнаульскаго у.) по дорогамъвъ воздъланной степи. Дал'ье онъ намъ попадался въ Павлодарскомъ у взды близъ оз. Маралды, близъ г. Павлодага и въ окрестностяхъ стан. Семиярской. Отъ А. Н. В елижан и на я получилъ экз. из'ь Кривинскаго пое. Семипалатинской бобл. Экспедипіею проф. В. В. Са п о жн и о в а 1902 г. достав.пенъ въ музей одинғ экземпляръ.

Ұкземпляры коллегіиій:

1) ᄒ аd. пос. Ііривинскіиї 10/1 02 r. 13 а. 118 с. 70 t 24 шк.
2) б ad. (‘. Ключевое
$9 /$ VII 02
$13, \overline{5} \quad 119 \quad 68$
$24 \quad$ 
3) sex? јuv. ст. Семиярская 24/vi 02

4) б juv. 26 r'I 02

5) sex? juv.

23 мум.

6) ad. ст. Чернорьцкая-। Черноярская

\section{0\%. Melanocorypha calandra psammochroa Hartert. अRaвороповь стенной.}

ВҺроятно къ этому недавно установленному шодвиду относится указаніє А. Мор озо ва (стр. 14), о томъ, что на юго-востокち Акмолинской обл. рБдко встрбтается жаворонокъ степной. Другихъ данныхъ нетъъ.

\section{Melanocorypha yeltoniensis Forst. JKanoponok' черіы тат̆рскій.}

(Alauda tatarica Pall.)

Экспедиціею проф. В. В. С а по ж н и о в а 1902 г. допыто два экззємпляра этого жаворонка близъ ст. Ямышевской. Размьры ихъ превосходятъ измъренія, привєденныя у Hartert'a. Судя по разсказамъ м'ьстныхъ жителей. черный жаворонокъ въ Кулундинской степи ежегодно появляется зимою, напр. въ окрестностяхъ дер. Чистоозерской, гдь по выряженію одного охотника „зимою закрывае'ъ дороги какъ скворцы“. Нъ Павлодарғ русскіе жители, по разсказамъ, осенью ловятъ черныхъ жаворонковъ силками и употребляютъ ихъ въ пишу. $\mathrm{D}_{\mathfrak{5}}$ окрестностяхъ ст. Семиярской зимюю встрбчаются во множествь. На сколько Іъъ съверу простираются зимнія кочевки чернаго жаворонка можно отчасти судить на основаніи люгезнаго сообщенія П. А. Шастовскаго, который во время пребыванія весною 1904 г. на ст. Каинск"ь вблизи ея видъль 26-го марта стаю птицъ, величиною сп скворцовъ, носившихся в' степи. Но вт отличіе отъ скворцовъ особи были черныя и свьтлыя въ перемежку и по полету онъ также отличались отъ скворцовъ. Нельзя не согласиться съ мнъніемъ әтого страстнаго любителя прироцы, что онъ видћлъ татарскихъ жаворонковъ. На этотъ разъ онъ мнь не могъ доставить экземпляра, такъ какь волизи станціи всльдствіе военнаго положенія стрьльба была запрещена. По сообщенію А. П. 
В ели жан ин а черныи жаворонокъ зимою иногда появ.летет около Барнаула.

Въ моей частной коллекціи одинь экземплярь, въ университетской два:

1) б аd.г. ІІавлодаръ лекабрь $01 \quad$ r. 16 а. 136 с. 83 t. 24 шк.

2) баd. ст. Ямышевск. 9/ю $02 \quad 18 \quad 132 \quad 78 \quad 27$ n

$\begin{array}{llllllll}3) & \text { tad. } & 9 / \mathrm{IV} & 02 & 17 & 136 & 81 & 24\end{array}$

U. H'ins ch (crp. 225) получиль отъ И. Я. С л о в ц о а әкземпляръ изъ окрестностей Омска, гдњ онъ рьдко (зимою?) встрьчается по дорогамъ (А. M орозов ъ стр. 14). Самому F i n s c h’ y удалось лишь въ 22 верстахъ оть Семипалатинска уридъть черныхъ жаворонковъ, которые здьсь находились во множествъ. Но по В. Н ПІ лотн и к ову (стр. 11) татарскій жаворонокъ гньздится и съвернбе Семипалатинска. Въ окрестностяхъ пос. Ямышевскаго онь очень обыкновененъ; здьсь льтомь его можно всірђтить на пашняхь и на солонцахъ. Для Кокчетавскаго уъзда въ качествь рьдкой птицы указант И Я. Сл о в п в ы м (стр. 148). Въ Акмолинскомь убздь найденъ экспедиціею П. Г. И г н атов а (Біа н и стр. 4), а въ Омскомъ убздъ В. С. Ел п а т в е вски м в (стр. 147).

\section{Otocorys alpestris flava Gmel. Haворонокт pora- тый полырный палеарктическій.}

Этотъ жаворонокъ приналлежитъ, лишь къ числу пролетныхъ и зимующихь посьтителей района напихъ изсльдованій и во время нашихъ поьздокъ не могъ всгрьтитья. Въ университетской коллекпіи два экземпляра, добытые проф. $\mathrm{K}$ а щ е н к 0 подъ Томскомъ 28/IV 92. Въ моей частной коллекціи экземпляръ, добытый подъ Томскомъ 27/u. 02. H. O b e r ho 1 s e r совершено основательно приводитъ полярнаго жәворонка стараго свъта подъ Гмелгновским' названіемъ.

Подьь Омскомъ наблюдается во время пролета (O. F i ns ch стр. 226). Сопб́щеніе А. М о р о п в а (стр. 14), заимствованное у И. Сло в ц о в а (стр. 149), что этотъ видъ въ, Омскомъ и Петропдвловскомъ уъздахъ встрьчается на солончакахъ, по моему мньнію, должно быть отнесено къ сльдующему виду, который только и можетъ льтомт. встрђчаться вь нашихъ степяхъ. Сооб́. 
щеніе В. Н. П .т о т н и ғ о в а (стр. 11) о ,снбжномъ жаворонкъ“ (латинское названіе птички пропущено), иззъстномъ у казаковъ подъ названіем’ь „рпгатика“ и встрбчающемся въ большомъ количествђ зимою по дорогамъ, несомнънно относится къ нашему виду.

\section{Otocorys longirostris sibirica Swinhoe. Honbopo- нов: рогатый свитлый.}

(O. brandti Dresser.)

Свътлый рогатый жаворонокъ, хорошо извђстный мнћ съ Алтая, найденъ мною въ степной части нашего края лишь в̈ъ степи на лђвомъ берегу Иртыша противъ стан. Семиярской.

Экземпляры коллекціи:

1) む juv. ст. Семиярская 26 ri 02 r. 13 a. 104 c. 64 t. 21,5 шк. 2) sex? $\quad$ 26/ иi $02 \quad$ ? $102 \quad 71 \quad 21$ мум.

Второй экз. сильно линяегъ.

Думаю, что сказанное А. М орозовымъ (стр. 14) подъ „О. alpestris l'p." относитея къ этому виду. Странно, что В. Н. Плотн иковъ въ окрестностяхъ пос. Ямышевскаго не паходиль әтого рогатаго жаворонка. Экследиція II. Г. Игнатова нашла этоть видт въ Атбасарскомт ућздь (В. Біанки стр. 3).

\section{Sturnus vulgaris moltorntzkyi Finsch. Скворецт сибирекій.}

\section{(St. menzbieri Sharpe.)}

IIo E. Hartert'y (стр. 44). Sturnus menzbieri Sharpe 1888 не болье какъ синонимъ описанний ранъе О. Finsch'емъ въ 1878 г. формы. Скворецъ обыковенная гнђздящаяся въ Барабинской степи птица. Везды вл, селеніяхъ видны спворешни. Большія стаи сгворцовъ въ нбсколько соть особей я наблюдалъ 10/г 99 около ваимки на Убинскомт озерь; молодые скворцы, уже вполны окрьпшіе, вмбеть ст, родителями истребляли надоьдав:пій и отравлявшій паше пребываніе га этомъ изерт, „гнусъ ${ }^{*}$. Въ дневникъ записаны еще слћдуюшія мћстонахожденія: ст. Татарская, ст. Коченево, ст. Каинскъ. Иат окрестностей посльдней я полу- 
чнль отъ П. А. Ш асто в ска го два экземп:яра, изъ окрестногтей Барнаула отъ А. II. В ели жанина одинь экземпляръ, изъ Семипалатинской области съ оз. Чушкалы одинъ эгземпляръ. Въ Кулундинской степи въ селеніяхъ обыкновенный скворецъ не рьдокъ. Экспедиція проф. Н. Ө. К а щ н ко достанила вт. напт, музей из'ь с. Јокоть два әкземпляра.

Экземпляры коллекцій:

1) $q$ г. Барнауль $26 /$ ки 98 r. 24 а. 126 с. 72 t. 30 шк.

2) sex? јич. ст. Уб́инская $12 / v$ v $9922 \quad 125 \quad 66 \quad 29,5$ "

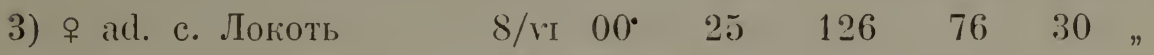

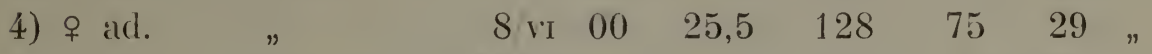

5) + ad c. Ключевпе 13 vil $02 \quad 25 \quad 128 \quad 75 \quad 29$,

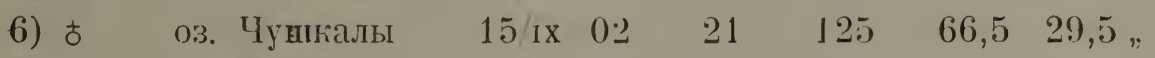

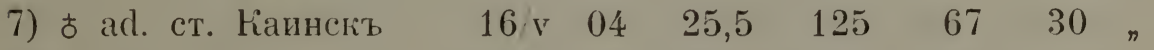

8) 우 ad. " $\quad 16 \mathrm{v} \quad 04 \quad 24,5 \quad 125 \quad 70 \quad 30 \quad$,

По литературнымъ свьдыніямъ этотъ скворецъ всюду въ разсматриваемой об.асти очень обыкновенная птица.

\section{0\%. Pastor roseus Linn. Розовый скворец'в.}

Розовый сгіворецъ, повидимому, гньздящаяся птица южной части степной полосы нашего края. Экспедиціею проф. Н. $\Theta$. K а щ е нк о 1900 г. добыто не менъе десяти экземпляровъ этого широко распространеннаго и несмотря на то огень погтояннаго, не поддающагося мбстнымъ вліяніямь и не измћняющагося подъ дъйствіемъ ихъ вида. Въ Кулундинскую степь стайки и даяе „табуны" розовыхъ скворцовъ залетаютъ; замұчены въ стени близъ дер. Чистоозерской. Большую стаю этихъ скво рцовъ я видьлъ близъ станицы Семиярской, но стрғлять не пришлось. По сообценію А. П. Ве л иж а н и н а розовые скворцы появились весною 1899 г. подъ Барнаугомъ.

Экземпляры колленціи:

1) ㅇ с. Убинское $1 /$ ri 00 r. 19,5 ad. 123 as. 122 c. 73 t. 30 шшк.

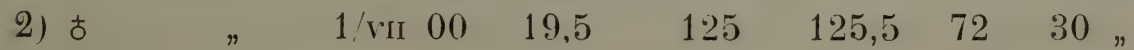

3) $+\quad " 30 /$ viI $00 \quad 20 \quad 12: 3,5 \quad 126,5 \quad 71 \quad 31$ "

$4)$ ? $" \quad 1 /$ VII $00 \quad 20 \quad 124,5$ ? $69,5 \quad 30$ "

5) 
6) ㅇ с. Уо́инское 3 ‥ 00

20,5

127

72 2s шк.

7) $ᄒ$

3 rII 00

21,5

134

$13 t$

7132 "

8) $\delta$

3 VII 00

20

130

131

$71,531 \%$

9) 甲 juv " 1 riI 09

20,5

120

120

10) \& juv " 3. vil 00

19,5

124

121

6830 "

11) баd. Кавказъ $6 r \quad 97$

$19,5 \quad 129$

129

$6730,5 "$

Посльдній экземпляръ, полученный мною отъ К. А. С а тун и н а. добытъ въ Талынской низменности и ничьмъ существеннымъ отъ сиоирскихъ не отличается.

Уже П. С. ІІ а л л а с ъ (стр. 420) указываетъ на Иртышъ и въ частности на Семиярскую станицу какъ нд мьстонахожденіе этого скворца. O. Finsch (стр 20ㄴ) наблюдалъ его въ степныхъ мћстностяхъ по сьвернынт склопамғ. Алтая по цорпг है къ Барнаулу, въ особенности близъ Колыванскаго озера. П. С. П а лл а с ъ въ другомъ мћсть (Rcise II Th. p. 511) указываетъ и на Старо-Шульбинскій заводт. Подъ Барнауломъ до Финш а и Вел и ж а н и н а наблюдалъ розовыхъ сцворцовъ С. Гу л я е в ъ около 1855 г., пом'встившій объ этомъ замътку въ 1870 г. въ Томскихъ Губернскихъ Вбдомостяхт, № 15 стр. 8).

O. Finsch получиль отъ И. Я. С ло в ц о в а әкземпяръ изъ Омска, куда по мньнію А. ІІ орозова (стр. 10) „случайно залетаеть во время сильныхъ бурь съ южнымъ вьтромъ “. Подт Ом. скомъ „дважды наблюдались при массовыхъ появленіяхъ попылки“. (См. И. Словцовъ 1897 г. стр. 146). Въ окрестностяхъ поселка Ямышевскаго розовый сгворецъ по соойенію В. Н. П ло тн и к о в а (стр. 9) постоянно не водится, но появляется полье пли менте значителиными стайками вь тま года, когда много саранчи.

\section{Trypanocorax frugilegus tschusii Hartert. Грач'b cuб́ирcкiї.}

Въ Барапинской степи грачъ мъстами очень обыкновенная птица. На ст. Коченево мы грачей не находили; по сообпенію мъгтныхъ жителей ихъ тамъ нбтъ. На станц. Убинской они встрбчаются рьдко и намъ не попадались. Близъ ст Каигскъ я замьтилъ грачей :30/vi 99 г. п получилъ отъ П. А. Шастовскаго шкурку и кладку этой птицы изъ ближайшихт, окрестіостей стәнціи. Въ онрестностяхъ станціи Татарской грачъ обык- 
новенная гнћздяшаяся птиџа. Наконецъ, большія стаи грачей мы видъли 23 гі 99 г. близъ станц. Калачинской, а около Омска ихъ было очень много. Отсюда вытекаетъ, что по мърђ удаленія на востокъ отъ Иртыша, число особей грачей уменьшается, причемъ область гнФздовья ихъ въ Барабь не доходить до ст. Убинской. Въ Кулундинской степи гратт гнЊздяпаяся птица. Первая колонія ихъ, всгрьченная нами во время побздги 1902 г. была в', д. П.отниковой, гдъ они населяютъ рошу- „борокъ“ около самой деревни. Одиночные экземпляры наблюдались близъ с. Вылкова. Въ рошь близъ д. Чистоозерской во время нашего тамъ пребыванія (23/vi - 1/viI) видны были на деревьяхъ кое. гдњ ихъ гнбзда; по разсказамъ весною 1902 г. буря повалила много яищъ и уже вылупившихся грапат’ь. Въ Павлодарскомъ у. мы видъли массу грачей близ'ъ оз. Маралды; наконец'ь, грачи замбчены и олизъ ст. Семиярской. Въ коллекціи проф. Н. Ө. Ка ще н ко 1900. г. одынъ грачт, $\mathrm{v}$ зъ приалтайскихъ степей.

Западно-сибиргкіе грачи по опредълителю E. Hartert'a должны быть отнесены к'ь установленному имъ новому подвиду. Весьма сожалью о томъ, что не могъ получить матеріала изъ Европы для сравненія и провърки вновь установленной формы.

Экземплярњ коллекцій:

1) $q$ ad. ст Татарская 19 vi 99 1. $\left.50(56)^{*}\right)$ a. 295 c. 176 t. 49 шк. 2) б juv. " $21 /$ ri $99 \quad 45(45) \quad 3050183 \quad 55$ " 3) \& аá. с Уо̆инское 26 vi $00 \quad 51,5(58) \quad 300 \quad 172 \quad 53.5$ "

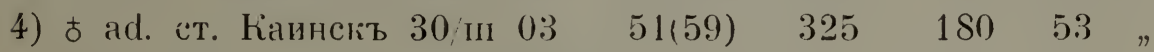

Кладка, доставленная мнъ П. А. Ша с т ов ски м ъ изъ окрестностей ст. Каинскъ, взята имъ 18-го мая 1903 г. и состоитъ изъ 4 яицъ. Три изт эาихъ яицъ нормальной величины, четвертое же гораздо меньше и очень темное. Одно изъ нихъ я передалъ въ уншверситетскую коллекцію. Размбры и въсъ ихъ:

$$
\begin{gathered}
\text { 1) } \frac{40,5 \times 29,2 \text { мм. }}{0,95 \text { гр. }} \text {;) } \frac{41,6 \times 28,0 \text { м.. }}{0,93 \text { гр. }} \text {; 3) } \frac{38,0 \times 28,0 \text { мм. }}{0,87 \mathrm{rр} .} \\
\text { 4) } \frac{29,2 \times 24,0 \text { мм. }}{0,67 \text { гр. }}
\end{gathered}
$$

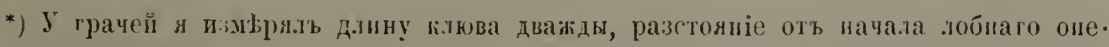
ренія ло конца клюва и длину одного лишь ребра верхняго к.лоса. Разность этихъ

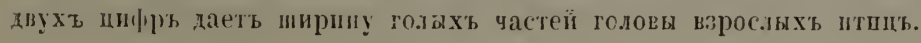


На широкое распространеніе в' Заиадной Сиб́ири грача указывають, уже слова П алласа (стр. 383) „in Sibiria cis-obensi... vulgatissima avis". O. F in s ch (стр. 192) наблюдаль грачей въ различныхъ мұстахъ, из' которыхъ для наст, важенъ трантъ мекду ()мскомъ и Семипалатинскомъ (г. Павлодарт). Въ Тобольской губ. грачъ найден'ь кромћ Фи нш а И Я. Слов цовы м ъ (стр. 247) и М. Д. Р уз ски м ъ (стр. 17). По И. Я. Словцову (1897 стр. 145) и А. Мор озо в у (стр. 10) въ Акмолинской обл. встрьчается , всюду, иногда огромными колоніями". Экспедиціей П. Г. Игнатова (Біанки стр. 2) добытъ въ Атбасарскомъ уғздь. Въ окрестностяхт пос. Ямышевскаго по В. Н. Пло т н к ко в у (стр. S) грачи гнtздуютъ въ топюлевыхъ и таловыхъ островахъ колоніями.

\section{Corvus rorax Linn. Bronourt.}

Вопрось о тон'ь, принадлежать-ли залално-ибирскіе вйроны къ европейскону подвиду соrax Linn. или представляютъ особую форму, пока еще не выясненъ

В’ь нашихъ коллекціяхъ изъ степей Томскаго края вороновъ ньть и во время экспедицій они не попадались. Въ долинғ Оби воронь гньздится, и между селами Уртамскимъ и Дуоровиной я 9/г 02 съ парохода наблюдаль цьлую семью вороновъ; состояв шую изъ семи особей. Молодые ужіе хорлшо летали. Зиною воेроны несомнћнно посђщаютъ наши степи. O. F i n s c h (cтp. 190) указываеть на отсутствіе ворона въ о́езльсной степи. По И. Я. С л о в ц в у (стр 2+7) воронъ распространенъ во всей Тоболь. ской губ., въ южнпй полюсь которой найдень и М. Рузским (стр. 17) IIо A. $\mathrm{M} \rho$ ро $3 о$ в у (стр. 10) воронт „обычная, но не часто встрђчающаяся птица “. В. Н. П ло т н и ко в ы м ъ для окрестностей пос. Ямышевскаго не упоминается и въ коллекціи П. Г. Иігнатова изъ Агмолинской обл. отсутетвуетъ. Но И. Я. С.говцо в у (1897 г. стр. 145) вороньь въ Омскљ, такъ же какъ и во всей Акмолинской области „появляется одиночкани“. Добыть б.изъ станищы Щученской.

\section{Corvus cornix sharpei Oates. Bopona chipag cúmp-}

\section{(0):iat.}

Восточная форма сърой вороны очень распространена на гньздовь' въ степяхь налшего крал, оудучи на Алтағ и въ во- 
сточныхь частяхь Томской губ замђнена черной. Мы находили ее какь въ Барабинской, такъ и въ Кулундинской степяхт. По Иртышу очень обыкновенна. Проф). Н. Ө. К а щ е н по о найдена в'ь д. Cayust's

Экземпляры коллегцій:

1) む ad. ст. Убинская 8/г 99 r. 47 a. 310 c. 180 t. 56 шк.

Весною 1904 г. я получилъ отъ П. А. Ш а с то в скаго өдно яйцо сърой вороны изт огрестностей ст. Каинскт, основной

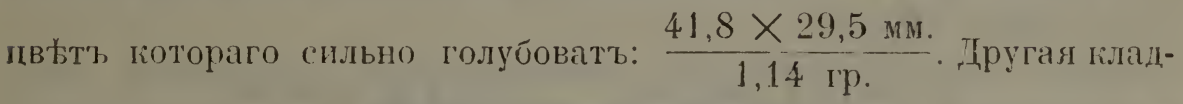
ка, взятая тамъ же 14 r 05 состоитъ изъ трехъ яицъ пбыкновенной окраски: 1) $\frac{43,0 \times 30,0 \text { мм. }}{1,28 \text { гр }}$; ) $\begin{gathered}42,5 \times 29,0 \text { мм. } \\ 1,29 \text { гр. }\end{gathered}$;) $\begin{gathered}43,0 \times 29,0 \text { мм. } \\ 1,30 \text { гр. }\end{gathered}$. Јитературныя дінныя особеннаго интереса не представляютъ

\section{Corvus corone orientalis Eversm. Чepнag вopona снбирская.}

Черная ворона во время поћздокт, по степямъ нашего грая не наблюдалась. Зимюю несомнынно посЊпаетъ степи, кочуя изъ области гнбъдовья въ западноми и югозападномь направленіп. Приводится В. Н. Плот н и ко в м т. (стр. 8) для пос. Ямышевскаго въ качествћ довольно рбдкой (зимующей?) посьтительницы.

\section{- Corvus cornix sharpei Oates $\times$ Corvus corone orien- talis Eversm.}

Гиориды сьрпй и чернои воронт очень часто встрғчаются между Томскомъ и Красноярскомъ. Отсюда зимою наиравляются ежегдно вт, Томскт, и далье на западт и югозападъ въ стеши, гды найдены мезіду прсчим'ь и на Иртышб (В. Н. Плотниковт стр. 8).

\section{1:. Coloeus monedula collaris Drumm. Галка onей- никовая.}

Галка весьма обыкновенна на гнъздовьж въ степяхъ нашего края. Въ Барабинской стеши она по моимъ наблюденіямъ болье многочисленна, чьмъ вา, Кулундинской. Здъсь намъ удалось ее 
просльъдить до ст. Семиярской. Въ Барабь попадались экземпляры и съ очень слабо развитымъ, почти отсутствовавшимъ „ошейникомъ“.

\section{Экземпляры коллекцій:}

1) む ad. ст. Убинская 12 vi 99 r. 32 a. 232 с. 139 t. 44 шк.

2) sex? $10 /$ vi $99 \quad 31,5 \quad 238$

3) о ad. д. Саушка $31 / \mathrm{v} \quad 00 \quad 30,5 \quad 240$ 13443 " 13944 "

Разм.бры и въсъ двухь яицъ изъ окрестн. ст. Каинскъ отъ 10-го марта 1907 г.

$$
\text { 1) } \frac{36,5 \times 25,0 \text { мм. }}{0,95 \text { гр. }} \text { и 2) } \frac{35,2 \times 25,0 \text { мм. }}{0,93 \text { гр. }}
$$

По сообщенію В. Н. П л о т н и к о в а (стр. 8) галки частью зимуютъ въ нашихъ степяхъ. Мнъ самому пришлось наблюдать зимующихъ въ Сибири галокъ 12-го декабря 1901 г. близъ IIeтропавловска. Въ Кокчетавскомъ ућздъ галки наблюдались И. Я. С ло в ц о в ы ъ $(1897$ стр. 145).

\section{Pica pica bactriana Bonap. Copora бълонадхво- cтนaม.}

$$
\text { ( = Pica leucoptera Gould.) }
$$

Мьстн. назв.: „соросейка“ (ст. Семиярская).

E. Hartert (стр. 21) сообщаетъ, что ему не удалось установить различія между подвидами bactriana, leucoptera и kamtschatica. Такимъ образомъ весь сьъверь Азіи населенъ только одной формой сороки, которую сльдуетъ назвать bactriana.

Сорока въ степяхъ нашего края счень распространена въ качествь осьдлой птицы, встрьчающейся всюду, гдь есть хотябы березовые колки.

Экземпляры коллекцій:

1) む juv. ст. Убинская 10 ri 99 r. 27 а. 194 с. 174 t. 47 шк. 2) ᄒ аd. с. Вылково 18/г $112 \quad 36 \quad 233 \quad 265 \quad 51$ ”

А. М ор озо в т, (стр. 10) приводить сибирскую сороку нодъ названіемъ „Р. caudata“. Эта ошибка ничтожна въ сравненіи съ промахомъ, допущеннымз имъ одной строчкой ниже. Онъ ци- 
шет`ь: „P. leucoptera. Голубая сорока По разсказамъ встрбчаетея въ юго-западной части Акмолинск. об.л."-Pica leucoptera во всякомъ случат не „голубая сорока“ (Cуапоріса), и голубыхъ сорокъ мы въ нашихъ степяхъ не найдемъ; скоръе әти „разсказы“, сообщенные г. Моро зо в у могутт, быть отнесены гіъ Роdoces panderi Fisch., о нахожденіи потораго въ нашихъ степяхъ впрочемъ у меня пока нътъ никакихъ указаній. И. Я. С' ло вцов т. (1897 г. стр. 146) привэдитъ сороку для Кокчетавскаго убзда подт названіем'ь „Pica europea Cuv.“.

\section{Nucifraga caryocatactes macrorhynchos Brehm. кедровна сибирская.}

lieдровка, гнҰздящаяея мъстамп вь значительномъ количествђ въ льсахъ Западной Сибири, во врема осеннихъ кочевокъ иногда посьщаеть и степи нашего края, о чемъ имбются указанія въ литературб. Такъ $\mathrm{M}$ е уе $\mathrm{r}$ въ описаніи путешествія (стр. 431 ) упоминаеть о значцтельном' пролеть кедровокъ съ запада на востокъ близъ Каркараловъ. Подъ Омскомъ кедровка встрь⿱чается по И. Словцов у (1897 г. стр. 146) и по А. Норозов у (стр. 10). В. Н. ІІ о т ник овъ (стр. 7) в' окрестностяхъ пос. Ямышевскаго встрьтилъ 2-го сентября 1892 г. пару зтихъ птиць, изъ которыхъ одну убил'ь. Намь во время повздокъ кедровка дазке и въ сосновыхъ борахъ. Кулундинский степи ие попадалась. Кочующихъ осенью въ Барабинской степи кедровокъ П. А. Ш а с то в с ко м у въ Кіаинскомь у. называли „рябыми галками“.

\section{Garrulus glandarius brandtii Eversm. Coülia cu- бирская.}

Сойка въ наших'ь коллекціяхъ изъ степной части Томскаго края отсутствуетъ. Изъ окрестностей Барнаула я видълъ экземпляры этого вида. Въ борахь Кулундинской степи нами не найдена. По А. Моровову (стр. 10) сойка нербдко встрьчается осенью въ качествь случайной формы для Акмолинской области, 1S/1х добыта и Словцовым ь (1897 стр. 146); для южной полосы Тобольской губ. не приводится М. Д. Руз ским а а также не упоминается В. Н. Плотй ко вымъ для пос. Ямышев- 
скаго. И. Я. С.ловцов в иъ Кокчетавскомъ, Петропавиовском. и Аюиолинскомь уьздахъ соекъ не находиль (стр. 146).

\section{Perisoreus infinstus sibiricus Tacz. Ponжia.}

$$
\text { (= Corvus mimus Pall.) }
$$

Ронжа, какъ таежная птица, населяетъ пограничные съ, на шими степями льса и урманы и въ степи можетъ появиться только спучайно. Изъ окрестностей Барнаула въ моей коллекции экземіляръ, полученный отт, А. II. В ели жанин а. Его изльренія;

1) t ad. 16 v.⿲I 98 r. 20 a. 144 c. 144 t. 38 mik.

Јо А. Морозову (стр. 10) ронка осеньн) подъ Омскомъ встрђчается нербдко, но является липь случайной посьтительшицею.

Нами во время нашихъ побздокъ, даже въ сосновыхь борахт, fуулундиской степи, ронжа не найдена. Iо сообщенію II. A. ШІ а стивскаго ронжа и сойка ему подъ Каинскомъ не попа. дались. 


\section{PICARIAE (Дят.ловыя).}

\section{1\%. Apus apus pekinensis Swinh. Стрижь kaмений чернщй.}

Иьстн. назв.: „етрижъ бог,овой“ (с. Вылково).

Ко.пнін каменныхъ стрижей найдеча была въ Кулундинскомь оору у с. Вылкова. Затъмт они замбчены были вт, с. Ключевомъ глизъ Сђвернаго бора, гдъ они летали, то надъ водою, то надъ берегомъ озера сравнительно че высопо надъ землег. Здъсь удалось добыть три экземпляра. Интересно, что въ Сибири ка. менный стрижт въ, нбсколькихъ мЂстахъ, между прючиюъ и около с. Нагорный Интанъ (в 40 в къ сьверу отъ Томска) мбстомъ гиъздовья выбираеть сосновые льса, причемъ избъгаетъ близлсти человтка. Такимъ мъстоиъ является и боръ у г. Вылкова, гды мы нашли множіество этихъ стрижей. Гньздовья въ борахь и льсахъ извъстны и изъ Западной Европы (Востолная Пруссія и Венгрія), а также изт Европ. Россіи и съ Урала*); въ Запалн. Сибири наблюдалъ это явленіе, повидимому линь М. Д. Рузскій. Въ Вылковскомъ бору стрижи летали на значительной высоть надъ деревьями и нашими ружьями здъсь ничего нельзя было сдьлать. Цришлось ограничиться наблюденіемъ ихъ, причемь Цейссовскій стереобинокль позволиль, ясно обнаружить отсутствіе бълаго цвъта на надхвость', такъ что я смъю утверждать, что здьсь не видьль әк:земп.ляровъ Apus pacificus Lath. Посльдняя форма была найгена на Алтағ, въ Салаирь и въ, приалтайскихъ степяхъ, между прочимъ О. F insch'емъ и А. B rehm'онъ, и какъ показали наблюденія проф. Н $\Theta . \digamma$ а щ е нко **) и мои личныя, оба вида қаменныхъ стрижей, черный и бълонадхвостный, живутт, очень часто вмбсть и летають смбшанными стаями. Указаніе проф. М е н з б и р а на стр. 411 его „ІІтицъ Россіи“,

*) См. нов изд. Науяана [V, стр. 234, и „Птицн Россіи" Мезбира стр. 413. М. Д. Рузскій (“тр). 19) наблюдаль сцижеї „въ бору на р. Іртыш's.

**) Результаты а.лтайской зосл. экспедиции. Томск' 1899 г. стр. 74. 
что сбверная граница стрижа в’ь Сибири спускается знатительно южнбе. чь̆ъ въ Европейской Россіи, и что онъ гнбздится на востокъ отъ Омека только приблизительно до $50^{\circ}$, на основаніи наблюденій, произведенныхъ въ Кулундинской степи и около устья р. Томи *) нужно считать невжрнымъ и нуждающимся въ поправкҒ. Добытые въ с. Ключевомъ и въ другихъ мбстахъ әкземп.яры, въ сравненіи съ им'ющимся въ моей частной коллекціи экземпляоиъ западно-евронейскаго происхожденія, отличаются нбсколько болье свђтлой окраской лба и передней части темени и надхвостья. На основаніи этихъ мелкихъ отличій приходится каменныхъ стрижей нашей степи считать принадлежащими къ подвиду pekinen sis, паселяющему съверную Азію. Отъ экз. алтайскаго происхожкденія наши әкз. не отличаются. Упомянутой въ „Науманнь “ стр. 233 болье свь̆тлой окраски рулевыхъ и второстепенныхъ маховыхъ я замьтить не могъ.

Экземпляры коллекціи:

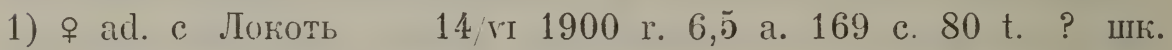
2) ᄒ semiad. с.Ключевое $12 /$ เи $1902 \quad 8 \quad 173 \quad 77 \quad 11$ " 3) sex? ad. " $\quad$ " $\quad 6 \quad 180 \quad 81 \quad 10$ мум. 3) + ad. $\quad " \quad 8 \quad 175 \quad 82 \quad 11$ шк.

\section{8. Арus pacificus Lath. Стрићт каменный бжлонад- хвостный.}

Степной экспедиціей проф. Н. Ө. К а щ е н к о 1900 г. собрано 6 шкурокъ этого вида въ дер. Саушкь.

Измьренія:

\begin{tabular}{|c|c|c|c|c|}
\hline $\begin{array}{l}\text { 1) } \delta \\
\text { 2) } ᄒ\end{array}$ & $\begin{array}{l}31 / \mathrm{r} \\
31 / \mathrm{r}\end{array}$ & $\begin{array}{l}8 \\
7\end{array}$ & $\begin{array}{l}178-180 \\
176-174\end{array}$ & $\begin{array}{c}85,5 \\
86\end{array}$ \\
\hline 3) & $4: \mathrm{rI}$ & 7 & 172 & 80,5 \\
\hline 4) ㅇ & $4 / \mathrm{VII}^{\prime}$ & 7 & 173,5 & 83 \\
\hline む & $4 / v$ & 7,5 & $174-175$ & 81 \\
\hline 6) & $4 / N I$ & $7, \tilde{5}$ & 182 & 85 \\
\hline
\end{tabular}

БЪлые кончнки перьевъ нияней стороны образуютъ цЊлый рндъ свЫтлыхъ поперечныхъ полосъ на всьхъ шести экземпляряхъ Іризнакъ молодыхъ?

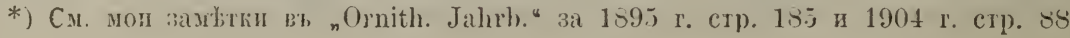


Въ. Коючетавскомт, убздь найденı, И. Я. С л о в цовы м ъ (стр. 140), гдњ, повидимому, тоже гнбздится въ́ сосновыхъ борахъ.

\section{Caprim Igus enropaens Linn. Lio30дой-полуночпй.}

Во время побздокъ по Барабинской степи козодой не быль добытъ, но проф. Н. Ө. К а ше н к о слышалт его мурлыканіе близъ станціи Татарской вечером' 18 vi 99. Степная экспедиція проф. Н. Ө. К а ще н к о допыла экземпляръ близъ пос. Шульбы 23/vi 1900 г. Въ предблахъ Кулундинской степи мы нашли козодоя тольюо въ Кулундинскомъ бору у села Вылкова. Мурльканіе его И. Н. Кі и р и лло в ъ и я слышали 19/ю1 1902 г. вечеромъ во время неудачной охоты на летучихт мшшей. Въ моей коллекціи имъ̌ется экз. изъ Барнаула. Ночью $28 / \mathrm{r} 9 \mathrm{~S}$ г. проф. Кащенко слышалъ его на пути между Барнауломъ и Бійскомъ*).

Измтренія:

1) ᄒ окр. Барнаула $16 /$ rш 98 r. 8 а. 190 c. 133 t. 16 ші. ч. кол. 2) пос. Шульб̋ 23 เг $00 \quad 9 \quad 186 \quad 144 \quad 16$ ”унив. ”

По В. Н. II ло тни к ов у на Иртыш в́ довольно обыкновенная птица (стр. 5). М. Д. Руз скій приводить его для бора на р. Иртышб въ южн. части Тобольской губ. (стр. 19). Finsch (стр. 149) получилт, зкз. изъ окр. Омска, не отличающійся отъ экземпляровъ германскихъ. ІЈо И. Словцову козодой водится по всему Кокчетавскому уњзду (стр. 139).

\section{Dryocopus martius Linn. Дятель-делна.}

О нахожденіи желны въ Барабинской степи мнб нитего не извъстно. Въ Кулундинской же степи желна наблюдалась въ бору у с. Вылкова 19/vi 02, но экз. не былъ добытъ. Встр'ьчается и въ бору у с. Ключевого. На Иртышб у стан. Семиярской в’ь со. сновомъ бору намъ не попадалась, также не упоминается В. $\mathrm{H}$. Пло тниковымъ для окр. пос. Ямышевскаго (стр. 7), но встрьчается по А. Морозову (стр. 15) „подъ Омскомъ рьдко“. Это указаніе заимствовано у И. Я. Словцова (1897 стр. 149), который считаетъ этого дясла кромь того, обитателемъ Кокчетавскаго уьзда ,во вс'ьхъ сосновыхт лћсахт,".

*) Результаты стр. 74 . 


\section{Gecinus canus Gmel. Сьдоголовый дате.лт.}

$$
\text { (= Picus chlorio Pall.) }
$$

Мћстное назв.: „зеленый дятель“ (ст. Татарская).

По сообщенію жителей станц. Татарской какой-то зеленый дятелъ встрбчается въ Барабинской степи. Намъ подоо̆ный цятелт не попада.лся и в'ь коллекціях'ь экземпляровъ нБт'ь. Я думаю, что рбчь была не о настоящемъ зеленомъ дятль (Gecinus viridis), а о сбдомь, столь распространепном' въ лиственныхт льсахъ нашего нрал Относительно нахожденія Gecinus viridis въ литератур̣ имъется лишь указаніе Палласа (стр. 40S) „versus Sibiriam sensim disparescit, ubique minus frequens $P$. chlorione“, всльдствіе котораго и Ф. Брандт ъ*) приводить зеленаго дятля въ своемъ списк' западно-сибирскихъ позвоночныхъ. Ни однимь изъ болье новыхъ изсльдователей это указаніе до сихъ поръ не нодтвержідено.

\section{Dendrocopus major cissa Pall. Cuб́pскiй бodburoŭ пестрый дителт.}

Меня поразило отсутствіе дятловъ в’ъ окр. ст. Убинской в’ь Барабинской степи, гды „рямъ“, представляюій изт себя торфяникъ съ низкорослыми сиснами, могъ бы ихт пріютить, въ особенности, такт какъ въ окр. Уб́инской имйются и поридочныя деревья, удобныя для гнђздовья. Зато этоть лятель обитатель Кулундинскаго бора у с. Вылкова. Здъсь 19/v1 02 мы нашли въ осинь гнғздо его съ тремя птенцами, уже хорошо оперенными, но не летавшими. Гнъздо былю обнаружено благодаря ихъ несмолкавшимъ крикамъ. Старыхъ дятловъ во̄лизи гнђзда не было видно. Очень поразило меня присутствіе этого дятла въ вполнь безльсной степи в’ъ дер. Нияній Кучукъ, гдъ подвижной, живой птичк' приходилось то прыгать по землғ, то лазать по стоявшей около „земской квартиры“ телегъ, колеса которой замьняли ей стволъ дерева, то неуклюжими прыжками передвигаться по крышъ покрытаго соломой хльва. Нербдокъ этоть дятель и въ борахъ у села Ключевого и близъ стан. Семиярской. Въ коллегціи изт приалтайскихъ 'степей экспедиціи 1900 года дятловъ нътъ. 1845 .

*) F. Brandt стр. 440 в'ь I'. 'Tschichatseff. Voyage scientifique dans l'Altai orientale 
Экземпляры коллекціи:

1) sех? јuv. Барнаульск. у.

с. Вылково . . . 19 ․ 02 r 20 а. 99 с. 54 t. 25 мум.

2) sex? juv. Барнаульск. у.

с. Выльвво . . . 19, гі $02 \quad 25 \quad 135 \quad 95 \quad 25$ "

3 ) sex? juv. Барнаульск. у.

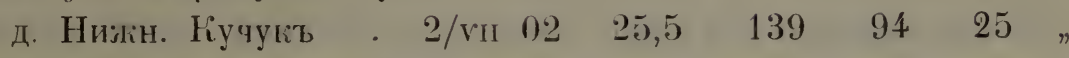

4) sex? juv. Барнаульск. у.

д. Нижн. Кучукъ . 5/гі $02 \quad 27 \quad 140 \quad 94 \quad 25$ "

5) sех? јuv. Барнаульск. у.

с. Ключевое. . . . $9 /$ rII $02 \quad 25 \quad 140 \quad 90 \quad 24 \quad$ "

6) sex? juv. Семипалатин. об.

ст. Семиярская +. 20/гі $02 \quad 26 \quad 137 \quad 92 \quad 26$ n

7) sex? juv. Семипалатин. об.

ст. Семиярская . . 29 vir $02 \quad 27 \quad 143 \quad 94,5 \quad 24,5$ ”

Что касается окраски нашихт экземпляровъ, то пна довольно измтнчива, но причинъ, не считать ихъ принадлежацими к"ı подвиду cissa, отличающемуся отъ западно-европейскихғ, главнымъ образомъ, лишь большею интенсивностью чернаго цвъта, нЊть (Сравн. новое изд. Н аум а н а стр. 279). Особенно вариируютః пятна на крайнихъ рулевыхъ: у экз. № 2 наружныя опахала двухъ крайнихъ рұлевыхъ съ каждой стороны совершенно лишены пятент. На внутреннихъ опахалахъ эти пятна выражіены слабо и не образують поперечныхъ полось, какъ у другихь экз. коллекціи, гдь полосы эти, впрочемт, выступаютъ тоже не особенно ръзко. Окраска нижней стороны далеко не чисто бълая, а болье или менъе грязнобълая, иногда съ желтоватымъ, иногда съ глинистымь оттьнкомъ. У одного экземпляра (№6) окраска нияней стороны чрезвычайно грязная и темная, буроватая, такъ что не отличается отъ окраски типичных'ь западно-европейскихъ D. major; кіоторыхъ мнб приходилось видбть. Этому признаку я не придаю серьезнаго значенія, такт какъ окраска эта можетъ быть чисто случайной, вызванной дыйствюем внбшнихь вліяній при лазаніи по стволамъ.

По А. Морозов у (стр. 15) этоть дятель „обыкновенный видъ всюду“. Шо В. Н. Ш лотникову (стр. 7) онъ гнђздится по Иртышу. Найденъ М. Д. Ру з ски м ъ. (стр. 17) вт березовыхъ рошахъ юга Тобольской губ. Вт көлленціи П. Г. Иг натова 
1зъ Аюмолинскей области онь пе огазался (Б і а н к и стр. 7 и 8), по В. С. Елп п т ьевским т (стр. 147) добыть въ Омскомъ, а И. Я. Словцовым т (стр. 149) вт Кокчетавском' убздъ.

\section{Dendrocopus minor pipra Pall. Cио́рскій малый

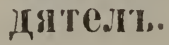

По сообщенію мъстныхъ жителей-грестьянъ этоть дятелокт, встрбчается въ окр. ст. Татарской (Каинскаго у.) и с. Ключевого (Барн. у.). Намъ не попддался. Вт, Фобольской губ. наблюдался Словцовымғ, Рузским'ь, Де рггиным т, Finsch'емт, ПІо А. Морозову (стр. 15) со словъ И. С ловцова (стр. 149) это „обыкновенный видъ вєюду, особенно часто подъ Омскомъ“, но В. Н. Плотниковым для Ямышевскаго поселка не приводится. Встрғчается подт, Барнауломт, (А. П Велижанинь). В's Кокчетавскомъ убздъ добытъ И. Л. С лов в о в м ж, (1897 стр. 149).

\section{Dendrocopus leuconotus cirris Pall.*) Cuбnpcrili бълоспиный дяте.ъ.}

Въ Барабинской степи этотъ дятелъ встрђчается: 27-го ікня 1899 г. намъ крестьянин принесъ одинъ экз. む, убитый близъ станц. Татарской. Экземплярт, оказался негоднымт к'ъ препарировачію, такъ кают, былт сильно разбить выстрбломъ и помлть во время доставги въ нашу препарировочную. А. Морозо вым ъ (стр. 15) встрбченъ однажды подъ Омскомъ. М. Д. Рузским т (стр. 19) найденъ въ сосновомъ (!) бору на Иртышљ.

\section{Apternus tridactylus crissoleucos Bn.**) Сиónpcriü трехпаный дыте.т.}

По И. Я. Словцову (стр. 149) убитъ около Омска 16/Iץ 1875 г.

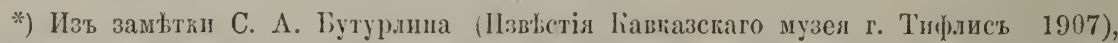
получепой мпою во время печатанія этой работы, пе вполпу явстьуеть, к'ь папой фор-

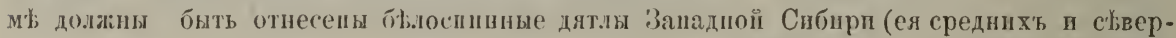

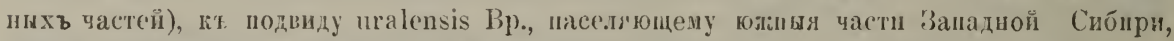
Алтай и Западыя части Висточной Сибири, или к'ь новому, еще пеопсаниому.

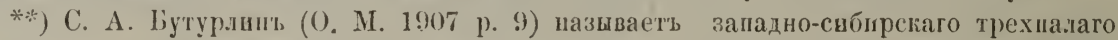
дятла P'ic. tr. uralensis и отдылеть сго оть средие-сипирекано и восточно-сибурскаго

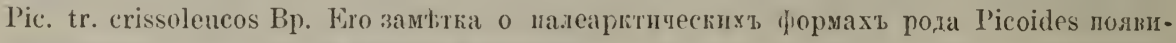
лась лишь ио время печатанія әтой работы. 
По А. Морозову (стр. 15) встрбчаетея подъ, Омскомт. Мны ничего не извыстно о нахожденіи его въ степной части нашего края. Вњроятно гнђздится и кочуетъ.

\section{Jyux torquilla Linn. Beptrirodobsa.}

Для окрестностей Омска приводится И. С л о вцо в ы ъ (1897 стр. 149). По А. М ор озов у (стр. 16) - встрбчается повсемъстно, но рьљ,дко О. Finsch (стр. 228) видь̆лт въ коллекціи Словцова әкземпляръ изъ окр. Омска. М. Д. Р ув ск и м ъ (стр. 17) найдена въ березовыхъ рощахъ пога Тобольской губ́. Мнж; нигдь въ степной части нашего края эта птица ге попадалась и въ коллецціяхъ экземпляровъ изъ степей Томскаго края н安ъ.

\section{2\%. Alcedo ispida sibirica Tschusi. Зимородокт си- бирекій.}

Во время побздки $1 \$ 99 \mathrm{r}$. по Барабинской степи намъ зимородокь не попадался. Чрезъ П. А. Ш а с то в ска го я пріобрблъ уо́итый М. А. А бр а мовым в на озерб близъ ст. Ka. инскъ $17 /$ r 04 экземпляръ, размъры котораго сообщаю нияе. По озерамъ Барабинской степи зимородокъ встр‡чается рБдко, на р. Оми же по слухамъ гнбздится. У А. Морозова (стр. 16) нахожну указаніе на одинъ экземпляръ, убитый подъ Омскомъ. Въ Кулундинской степи нами не наблюдался, но видблъ я зимородков’ь па р. Иртыш' близъ стан. Семиярской. В. Н. Плотниковъ (стр. 6) „только разъ вт 1895 г. видЂлъ этого зимородка. пролетающимъ надъ озеромъ “. Далье авторъ сообщаетъ, что разъ нашелъ молодыхъ зимородковъ „въ гнбздь стрижей, въ яру“. Думаю, что это было не гнбздовая норка Clivicnla riparia, a пастоящее гнь̆здо зимородка. Экспедиціею проф, Н. Ө. К а ще н к о 1900 г. въ нашъ музей доставлены изъ приалтайскихъ степей два экземпляра.

Измғренія:

3) $q$ ad. с. Поктевское

$\begin{array}{ccccccr}10 \text { vi } & 00 & \text { r. } 35 & \text { a. } 73 & \text { c. } 35 & \text { t. } & 9 \\ 1 / \text { rII } & 00 & 33 & 75 & 36 & 10 \\ 17 / \text { r } & 04 & 38 & 75 & 35 & 10\end{array}$

2) $q$ ad c. Убинское

$17 / \mathrm{r} \quad 04$

$38 \quad 75 \quad 3$.

10

Подт. Барнауломъ встрьчается часто. Западно-сиоирскіе зимородки изъ пкр, Томска и Барнаула, доставленные мною извъст- 
ному австріӥскому знатоку палеарктическихь птищ, l. von Tschusi, недавно *, были описаны этимь ученымт. какъ самостоятельный подвидъ подъ назвапіемъ sibirica. Я не зацумываюсь отнести къ этой формб и экз., полученный изъ Барабинской степи, какъ и әкземпляры сбора проф). $\mathrm{K}$ а щ $е$ н к о изъ приалтайскихъ, степей. Iо Tschusi западно сибирскіе зимородіи отличаютея сльвдунщими признаками:

Они гораздо меныше западныхъ ispida, меныше юзныхъ spatzi, можетъ быть нысклико крупнъе, чвмъ bengalensis. Кливъ короче, при основаніи довольно широкій, постепенно стуживающійся к'з конщу.

О кр а с к а ad.: Вејхняя сторопа и полоски, идущія оть боковыхъ вЊтвеи нижняго клюва голубого цвђта. Темя съ уз. кими поперечными полосами. Нижняя сторона, за исключеніемь былаго горла ржавожелтаго цв'та, по бокамъ болье ржавокраснаго.

О к р а с к а јuv.: Голова, крылья, плечи и полоски, идуція отю, боковылт в́бтвей нижняго клюва темнозеленаго цвыта. Нижняя сторона граснобурая. болье или менье тусклая, въ осопеп. ности на груди, всльдствіе сљрыхъ ободковъ пергевт.

\section{S. Coracias garpulus Linn. Cuвoboponia.}

Мвстн. назв : „ронжа“ (с. Вынково и с. Ключевое).

$\mathrm{Bz}$ Барабинской стеши сизсворонға нами не была добыта, равнымъ образомъ не находилъ ез около Капнска и II. А. II а.стов ск ій. По А. Морозову (стр. 16) и И. Я. С.ловцову (стр. 140) онь подъ Омскомь появляются рђдко, „спорадически “. Въ Кулундинскод̈ ('тепи она очень обыкновенная, гнбздящаяся птица. Намъ часто приходилось видђть ее сидящей на кольяхъ и столбахъ по дорогамъ. Первые экземпляры, попавшіе въ коллекцію, были замьчены около дер. Ключей; чаце эти грасивыя птицы стали попадаться по дорог के между с. Тюмешцевомъ и Вылковомъ 16-го іюня, въ степи въ окр. с. Вылкова, дер. Мысы, дер. Чистопзерской, д. Нияняго Кучука, въ бору у с. Ключевого, ПГ, В Н. Плоти ик ову (стр. 5) на Иртыш' „годами встрьчается вт довольно значителғномт, количеств b, а годами ея

*) Ornitholog. Jahrb. XV. 1904 (т) 99. 


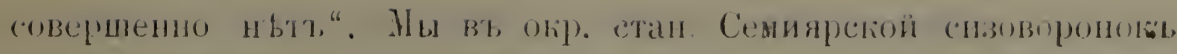
не находили. В丂 огр. Барнауда эта птица гнбіздтея; степная

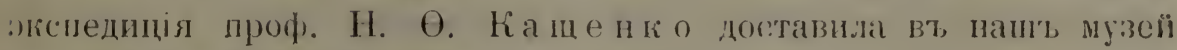
три шкурни (нос. Шульба),

Измтренія:

1) sех? ad. пос. Шульба 24 мт 00 г. 35 а. $191-195$ с 129 t. 2. шк.

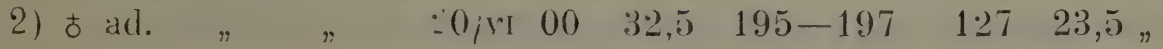

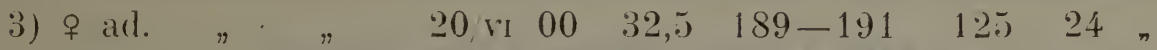

4) ᄒ ad. дер, Ключи 15 v1 $02 \quad 30 \quad 189 \quad 124 \quad 24$ ”

5) 우 ad. " $\quad 15 \mathrm{vI} 02 \quad 3: 3 \quad$ ? $128 \quad 24 \ldots$

6) бал. с. Вылиово 16 кі $0232 \quad 193 \quad 12624$,

7) ad. д. Н. Кучуки 6\% vir 0231 ? 11324 "

8) б аd. с. К.иючєвое $9 /$ vir $02 \quad 31,5 \quad 199 \quad 125 \quad 24$ ”

9) sex? juv. " $\quad 9$ vi $02 \quad 22,5 \quad 158 \quad 102 \quad 23$ "

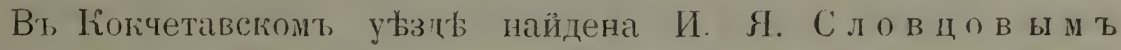
(стр. 140).

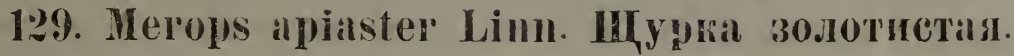

Мьстн. назв.: „зодотушник'ъ “ (Барнауль).

По Палласу (pag. 438) „ad Jrtin fi.r'arior“. П1о Э. Эверсманну *) "нерьдљо находится по южному Иртышу и около Норъ-Зайсана“. Замђмъ указния на нахожденіе этой красивой птипы нахожу у O. Hinsch'а и гr. Homeyer и Tancré.-A. М. Н и ко л в ь с кі ій (стр-188) самт „ни разу“ не наблюдаль ея.-А. Морозо в ъ (стр 16) сообщаеть, что на сьверђ Акмолинской области этой птицы нытъ, на югъ же она встрбчается довольно часто. Во время нашихъ пођздокь по Барабинской и Кулундинской степямъ, мы ни разу не встрђчали золотистой щурки. Только экспедиція проф. H О. І а щ е н к о 1900 г. в’ь приалтайския степп доставила въ нашъ музей семь шкурок' и одн чучело.

Измъренія:

\begin{tabular}{|c|c|c|c|c|c|c|}
\hline $\begin{array}{l}\text { 1) } ~ \\
\text { 2) } \\
\text { t } \mathrm{ad}\end{array}$ & Локоть & $\begin{array}{l}12 / \mathrm{VI} \\
13 / \mathrm{vI}^{\prime}\end{array}$ & $\begin{array}{c}34,5 \text { a. } \\
34\end{array}$ & $\begin{array}{l}141 \\
141\end{array}$ & c. 101,5 & t. $\quad 13$ \\
\hline 우 & $"$ & $14 / r$ & $.32,5$ & 143 & 109 & 12 \\
\hline ᄒ ad. & & $14 / \mathrm{VI}$ & 36 & 152 & 116 & 12 \\
\hline
\end{tabular}

*) Еетесгенная исторія Openóyрrскаго края. 1866 стр. 113. 
5) む ad. с. Локоть 14/vi

$$
35
$$

147

112

12

6) 우

$14 / \mathrm{vI}$

33

$147-146 \quad 110$

12

7) 우

$15 / \mathrm{VI}$

8)

13 , VI $\quad 35,5$

$140-141.6 \quad 103$

147

111,5

13 чуч.

Матеріала для сравненія июъ другихъ мъстъ у меня не имъется, кромґ одного чучела въ музеь изъ Гульджи, которое ничъмъ существенным оть нашихъ экземпляровъ не отличается.

\section{Uрupa epops Limn. Удод}

Мљетн. назв: „пьтушекъ“ (дер. Пиотниюова), „потатуйка“, „гребняшка“ (с. Вылково).

Удодъ, область распространенія котораго въ предблахъ нашего грая весьма обширна (ньсколько разъ выводки были находимы въ окр. г. Томска *), очень пбыкновенная птица степной части губерніи, кром' разв` Барабинской степи, гд屯 намъ наблюдать его не приходилось. Равнымъ образомъ П. А. ШІ а с т о вс к і й ничего не могъ мнь сообщить о нахожденіи тамъ удодовъ. "Пътушки" барабинцевъ представляютъ ничто иное, какъ турухтанов'ъ. Но въ Колывани О. ф о н ъ - Д и т м а р ъ их'ъ находиль. Во время побздки по Кулундинской степи удода находили въ дер. ІІпотниковой, гдь мы его наблюдали въ рощ' около самой деревни. Весьма обыкноңененъ онъ и въ Кулундинскомъ бору у с. Вылкова. 18 го іюня намъ здысь быль доставленъ молодой живой удодъ, вполнь оперившійся, но не научившійся еще впллнь летать. Эта птичка была такъ мила и забавна, что я не позволиль пүєвратить ее въ препаратъ. Ее отнесли въ льсьъ и отпустили. Удодъ найденъ затьмъ въ с. Ключевомъ и на Иртышь близъ стан. Семиярской. Степная экспедиція 1900 г. доставила въ музей экз. изъ с. Локоть, но не нашла удода въ д. Caywkt.

Измгененія:

1) 우 ad. с. Локоть. $13 / \mathrm{vi} 00$ r. 49 a. 138 c. 102,5 t. 23 шк.

2) ᄒ ad. д. Плогникова 14/vi $02 \quad 53.5 \quad 146 \quad$. $99 \quad 23$ ",

$\begin{array}{llllllll}3) \text { t } \mathrm{ad} \text { " }, \quad 14 / \mathrm{rr} & 02 & 57 & 146 & 108 & 23\end{array}$

4) sex! с. Вылково 17/vi 12 50 $141 \quad 107$ 22 мум.

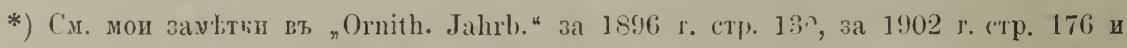
мою статью „О птицах' Тояской гуо̆." стр. 39. 
Подт Барнауломъ и на Алтағ удодъ обыкновененъ.

По А. Мороз ов у (стр. 16) подъ Омскоме "часто повсюду“. По В. Н. ПІ ло тн и ко в у (стр. 5) в'ь пос. Ямышевскомъ удодъ „птица очень обыкновенная “. Вэ, Петропавловскомъ и Кокчетавскомъ уЊздахъ удодъ И. Словцовымъ (стр. 140) не найден'ь.

\section{? Cuculus intermedius Vah1. Lìgyuna Masms.}

Кукушка малая или „глухая“, какъ ее зовутъ, подъ Томскомъ, за время трехъ пођздок'ь по степям'ь нашего края не была найдена. Разспросы мьстныхъ жителей не привели къ положительнымъ результатамъ. По свидбтельству В. С. Елпат ье в ск аго (стр. 146) два молодыхъ экз. этого вида добыты въ Омскомъ уъздь, но Въ правильности опредьленія я на основаніи указанныхъ авторомъ признаковъ сильно сомнћваюсь.

\section{Cuculus canorus johanseni Tschusi. Ryrynka cu- бирекая больная.}

Извъстный австрійскій орнитологъ V. von Tschusi въ 1903 г. ${ }^{*}$ ) выдъ.лилъ сибирскую обыкновенную кукушку, мною доставленную ему въ числ'ь нбсколькихъ экземплярпвъ изъ окр. Томска, какъ самостоятельную географическую разновидность. Отличительными признаками взрослыхъ самцовъ отъ типичной западноевропейской кукушки имъ указываются (лъдуюшіе: 1) нижняя сторона съ болъе р'ьдкими, узкими и бльдными поперечными полосками, 2) пятна нижнихъ кроющихъ хвоста почти совершенно прикрыты, такъ что эта часть оперенія кажется почти одноцвђтной, бълой съ желтоватымъ налетомъ, 3) окраска верхней стороны какъ у типичной формы, но съ болъе ръзко выраженнымь бурымъ налетомъ, 4) окраска нижней стороны отъ груди до клюва солье бльдная, такъ какъ линена голубоватаго оттьнка. Поперечныя полосы нижней стороны на половину уже, чь̌м у типичной формы.

Для сравненія кукушекъ, добытыхъ университетскими экспедиціями и момми препараторами ғъ степной части нашего грая, съ западной формой, мнъ послужили экземпляры, полученные отъ

*) Ornith. Jahrb. 1903 гтр. 165. 
Tschusi изт окрестностей г. Галлейна вт, Зальцоургъ. Степныя пукүшки оть добытыхъ въ окр. Томска не отличаютея, отличіе же сибирскихъ отъ австрійскихъ довольно рбззое.

К'ь тому же сибирскія особп отличаются отьь европейскихъ большими размђрами, въ особенности ллиною крыла. Особенности окраски, шсдмъченшыя von Tschusi, я вполнъ подтверждаю; въ особенности бросается въ глаза сравнительно узкая поперечная полосатость иижней стороны.

Большая кукушка был найдена въ Барабинской степи въ окр. станц. Убинской, на ст Татарской, ст. Каинскь; на ст. Коченево мы слышали кукованіе 2 > м. Въ. Гулундинской степи находили ее вт, дер. Плотниковой, въ бору у с. Вылкопа, близь с. Ключевого и около ст. Семилрс:ой на Иртыш'. Экспедиція 1900 г. цоставила әкз. иеъ дер. Саушки.

Изитрепія:

1) $t$ ad. дер. Саушка $3 /$ r 00 r. 20 а. 220 с. 176 t 21,5 шк.

2) t ad. с. Выльово 17/v1 02 2) $238 \quad 195 \quad 21$ ”

3) јun. ст. Семиярская 24/vi $02 \quad 21 \quad 216 \quad 187 \quad 215$ "

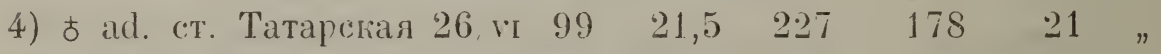

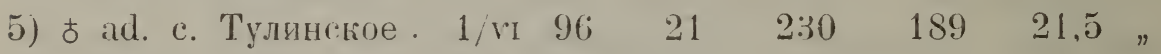

6) б ad. ст. Каинскъ $14 \mathrm{v} \quad 04 \quad 20,5 \quad 235 \quad 186 \quad 2.2 \quad$

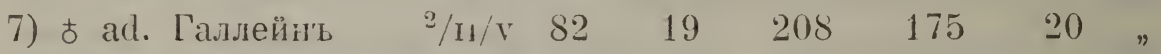

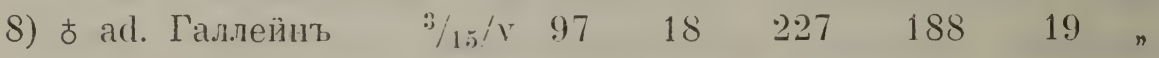

По литературнын, данымт, кукушка найдена повсемъстно. 


\section{RAP'TORE' (Хиніныя).}

\section{3:2. Bubo bubo sibiricus Schl. et Sus. Фи.лин-лугачь сио́ирскіïr.}

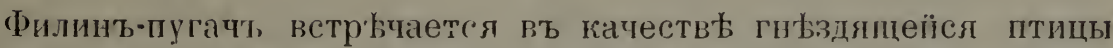
въ степяхъ нашего края. Въ Барабинской степи мнб извьстны сльдующія мьстонахожденія его: ст. Каинскъ, Татарская, Калачинская. Въ Кулундинской степи филинъ населяетъ не только боры, но встрбчается и въ колкахъ. Его особенно пресльдуютъ киргизы, такт какт нбкоторыя перья его идуть на украшеніе ихъ дъвичьихъ шапокъ. Въ киргизскихъ юртахъ поэтому нертдко можно найтв живого фнлина, который по мьрђ надобности и лишается нькоторыхъ частей оперенія. У меня записаны сльдующіе случаи, когда мнъ приходилось видұть филина въ неволь: юрты вт, окрестн. д. Чистоозерсгіой, юрты близъ Нижняго Кучука, с. Ключевое, въ сосновомъ бору близт котораго филинт, гиъ̆здится. Вт, коллекціяхт одинъ экз., доставленный намъ живымъ на ст. Калачинской 24 гг 99 из'ь с. Оюонишникова, Покров. ской во.г., Тюкалинскаго у. Тобольской губ., гдъ былъ пойманъ в’ апрғыл 1899 г. Опереніе его ног'ь не такое густое, какъ у томскихъ зимнихъ экземпляровъ, что легко объясняется измъненіями въ зависимости отъ времени года.

Измъренія его;

1) t ad. $24 /$ ri 99 r. 45 a. 450 c. 290 t. 88 ? шк

$\mathrm{B}_{\mathbf{5}}$ приалтайскихъ степяхъ въ д. Саушкъ былъ доставленъ шроф. Н. Ө. Ка ще нко З-го іюня филинъ, но экземп. былъ настолько избитый и поврежденный; что его не взяли:

Такъ какт, яйца сибирскаГо филина, повидимомў, мало или даже, быть можеть, совсьмл, неизвъстны *), я позволю себъ привести зд屯сь размъры и въсъ двухх чиетобъльхъ яицъ одной

*) L. Taczanowski, Faune ornithol. de la Sibérie orientale 1891 pag. 147) не дaets описанія яиць этого филина; ІІ. Я. (Һовцовъ, по поторожу (стр. 24?) гнђздо со совер-

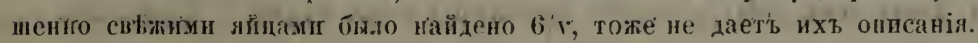




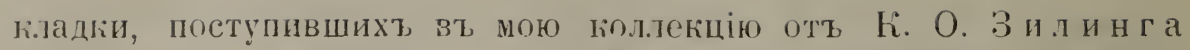
изъ с. Тунды, Маріинскаго у. Томской губ́., гды гнъздо найдено было весною 1901 г. К.тадка состояла изъ 3 яицъ.

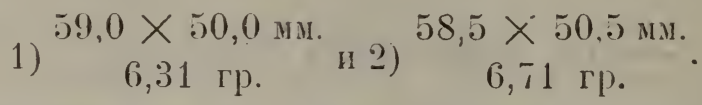

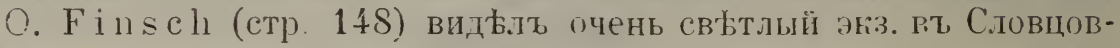
ской колтекціи вт, Омскь. По И. Я. Словцову (стр. 242) филинь встрьчӓетсл въ средней и южной части Тобольской губ. откуда не упоминается М. Рузскимљ. По А. Мор пзову (стр. 9) филинъ встрьчается нерьдко, но подт Омскомъ лишь въ качествь, повидимому, залетной птицы.

По В. Н. Плотников у (стр. 4) филинъ залетаеть въ окрестности пос. Ялыневскаго въ очень рьдкихт случаяхъ „какъ нужно полагать, изъ сос‡днихт боровт.".

\section{Scops giu Scop. Conka-ch.7omlia (3opbria).}

$$
\text { ( = Scops stranchi Bogd.) }
$$

П. С. Палласъ (стр. 310), приводя татарское названіе этой маленькой совы, говоритт, что она довольно часто встрьчается въ Западной Сиоири. O. Fins ch совсьиъ не упонинаетъ этой совы. По мнъиію гг. Homeyer и Тапсré (стр. 83) единственный экземплярь, полученный ими, отличается оть германскихъ меньшими размьрами и болье темной окраской. А. М. Никольскимъ (стр. 187) сова эта доб̆ыта на Алтағ. По И. Я. Сло в по в у зорька добыта въ началь мая близь Тюмени и здћсь появляется негравильно (стр. 243). По М. Р у з кому (стр. 17) она встрь. чается въ березовыхъ роџахъ южной полосы Тобольской губ. А. Морозовъ (стр. 9) ньсколько разъ слышалъ подъ Омскомъ характерный кірик этой совы. Намь во время нашихъ пођздокъ эта сова, найденная подъ Тонсюомь въ качествђ осђдлой, не попадалась; но несмотря на это, пна долғна быть причислена къ авифрауны нашихъ степей.

Сюда же относится үказаніе И. Я. Словцов д (1S97 стр. 139) что „Scops Strauchi Bogd.“ добытъ въ числь двухъ эгз. около Омска 1-го мая $187 \mathrm{~S}$ г. въ камышахъ на берегу Иртыша̣. 


\section{Nyctea scandiaca Linn. Cona orsias.}

$$
\text { ( = Nyctea nivea Linn ) }
$$

Вю) время осеннихт, и зимнихь кочевокт, овлая сова, гивздя-

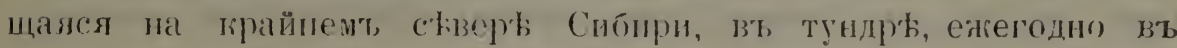

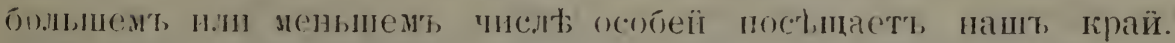
1]. А. Шастовскому приходилось паблюдать ее поды Каин-

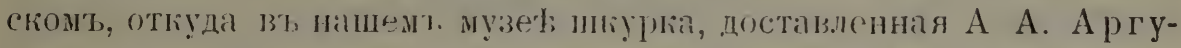
но вы ма. Мив прихлдлось слышать разсказы о ней въ д. Чистоозејской и въ е. Кллчевомт, (Кулунииская стень). Бљлая сова на основаніи литературныхт, источниковт, тапже должна быть, признана веснма обынновенной в', панихт, степяхъ в’ь зимиее время.

Эки. коллекцій:

1) 우 juп. г. Каинскт янв. 1903 г. г. 34 а. 450 с. 250 t. оволо 60

\section{Sumia ulula doliata Pall. Coвa scтреб́nas cuб́p- ская.}

$$
(=\mathrm{S} \text { ulula pallasi Buturl.) }
$$

Какъ подт Томскомт, такъ и въ Барабинской степи эта сова довол:но часто попадается вт теченіе зимнихъ мбсяцевъ. О гијздованіи ея въ пашихъ степяхъ я ничего узнать не могъ.

O. F insch (стр. 146) видьль въ коллекціи С.л о вцо ва экз. изъ окрестностей Омска, откуда не приводится А. М ор озовы м т, который почему то Glaucidium passerinuш называеть „ястребиной совой“. По Словцову (стр. 243) эта сова зимчетъ въ 'Ткменскомъ у., гдь гнъзда ея находили въ. еловыхъ борахъ. Въ Кікчетавскомъ у. найдена, повидимому, гнбздящейся И. भ. С.л о цо в ы м (стр. 139).

\section{Glancidium passerinum Linn. С̆чь-воробей.}

Сычъ-воробеї во время побздки 1902 г. былъ намъ ноставленъ только раз’ въ дер. Іллотниковой, Барнаульскаг, у., 15-го іюня деревенскими мальчиками, поймавиими эту совку въ, дупль старой березы в'ь рощь близт деревни. По ихъ словамъ вт, гнызды было три яйца, гіторыя ими по неосторожности были разоиты. Сычикт не попалъ въ нашу коллекцю, такљ какт, сопровождавшій меня препараторъ выпустиль нечаяпно итицу изъ рук'ь, а 
она моментальн исчезла чрезъ открытое окно сосьдней комнаты. Объ этой неудачћ приходится сожальть тьмь болће, ч'то въ зоологическомт музећ нашего университета не им Ается матеріала, іозволяющаго судить о распространеніи этого вида въ нашемъ краъ Любуясь милой птичкой вщродолћепіе тъхъ немногихъ минутъ, въ которыя мнб пришлось ее видьть, я, разумћется, не могь установить точно, къ какому подвиду принадлежаль видынный экземлляръ. Такъ какъ пока не имғется данных' о нахожденіи восточной формы (Glaucidium passerinum orientale Tacz.) въ нашемт крағ, я привожу эту совку подъ названіемъ, присвоеннымъ западной форм'ь.

Вт литературь имћется пишь очень немного указаній на на хожденіе сыча-воробья въ Западной Сио́ири. П. С. П а ллас ъ не приводитъ этой маленғой совы, его S. passerina не болье какъ Nyctala tengmalmi. L. v. Schrenck (стр. 249) высказываеть предположеніе, что этоть видь „wahrscheinlich quer durch ganz Sibirien verbreitet“. Вь рабоотахъ O. Fin s c h’ a, Hom e y e r’ a и Тапсге́, К. М. Д ерюгина, М. Д. Рузскаго, касаюшихся орнитофауны Западної Сиоири, сова воробьиная не упоминается вовсе. И. Я Словцовъ $($ стр. 242) приволитъ ее для Тюменскаго округа, А М р озов њ, (стр. 9) считаетъ ее для Омска лишь пролетной. По В. Н. Плотникову (стр. 4) эта сова въ окрестностяхъ пос. Ямышевскаго встрђчается на лугахъ, въ перельскахъ и иногда появляется въ самомъ поселкъ. По проф. M. А. М е нзб ир у („Птицы Россіи“ стр. 267) „сычикъ на востокљ отъ Европейской Россіи раскространенъ по всей льсный ооласти Сиоири".

\section{3\%. Otus otus Limn. Coвa ymactag.}

Во время поьздки по Бараб́ 1899 г. эта сова не была добыта. ऊКивой эқземплярт, этого вида намъ доставили 3 ил 99 на ст. Коченево и живымъ быль доставленъ въ Томскъ. Здысь онъ ногибъ во время занятій әкспедиціи вт восточной части губерніи и некому о̆ло препарировать его, почему вь коллекціи вещественнаго доюазательства нахожденія этой совы нытъ. П. А. III а стовскій, впрочемъ, находиль ее в'ь окрестностяхт ст. Каннскъ. Во время другихъ пођздокъ она также не добыта.

О. F i n s c h (ютр. 148) видьль въ Словцовской коллекціи экз. пзъ онрестнсстей Омска. И. Я. С ло в ц в в. (стр. 244) приводитъ 
эту сову дия окрестнстей Тюмени. М. Рузскін (стр. 16) находиль ее вт березовых'ы роцахт киной по.лосы Тобольской гуо По А. Морозов (стү) 9) обычная форма подт Оискомт. Вт,

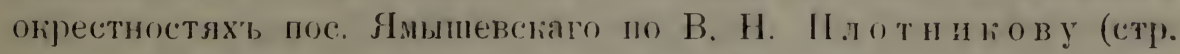
4) очень обыниовенная, гньздяцаяся, птнц.

\section{Asio accipitriuns pallidus Sar. et Loud. Coba bo- лотная б.าห,цแลя.}

Болотная сова пироко распространена на гнбздовь в въ степяхь нашего края. Въ огрестностяхъ ст. Каинскъ П. А. III ас т о в скі й нашель $21 / r \quad 03$ нешолную кладку (одно лйцо) въ гнбізд, помьшавшемся посрединғ шйрокого куста. Яйцо это онъ считалъ принадлежащимъ какому-то свьтлому луню; но при осмотрю, его оказалось, что скорлупа не просвьчиваетъ зеленымъ цвђтомъ, столь характериымъ дпя яицт луней. Окраска яйца чисто бъ.лая. Яйцо это ничъмъ существеннымъ, не отличается отъ яицъ болотной совы, имъюпцхся в'ь моемъ раснорлженіи из", окрестностей Томска, а потому я не задумываюсь упомянуть о немт, здұсь. Размъры и въсъ его $\left(\frac{40,1 \times 32,5 \text { мм. }}{1,73 \text { гр. }}\right)$ также согласуются со соогвђтствуюцими да:нымп относите.пно яиц болотной совы изъ окрестностей Томска.

Въ Кулчндинской степи сова эта добыта въ окрестностяхь дер. Нпжній Кучукъ въ открытой, лишенной древесной растительности степи близъ озера. Въ окрестностяхт станицы Семиярской я виды.т'ғ, вТ, густой „забокы“ (тальниковыя зарости по Иртышу) әту сову, но стрблять не приплось. Эксиедиція проф. Н. $\Theta$. К а ш е н ко 1900 г. доставшла въ наш'ь музей два экземпляра әтого вида пзт, приалтайскихь степей, изъ котөрыхт одинц вы гньз:цвомт опереніи.

Әкземпляры коллекцій:

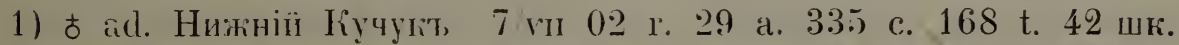

2) $t$ ad дер. Caymia 6 ri $00 \quad 28 \quad 300 \quad 146 \quad 40^{\prime}$,

3) б.juv. c. Lокоть 17 vi $00 \quad 27 \quad 130 \quad 73 \quad 40$ ”

Въ желуда' второго экз. пказались три черепа полевокъ.

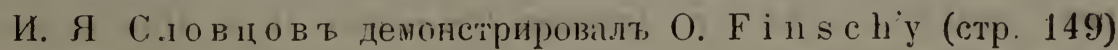
әкземпляръ из'ь окрестнпстей Омска Въ Тойольской губ̆. э’а сова 
широко распространена (С.ловцов'ь, Рузскій). По Морозову (стр. 9) обычная форма подъ Омскомъ Добыта В. С. Елпатьевски мъ (стр. 146) въь Омском' у. Д.я окрестностей пос. Ямышев-

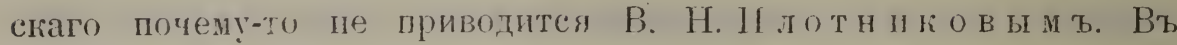
Кокчетавски у уздды всюду найдена И. С по в по в ы м т (стр. 138). Экепедиціею П. Г. Игиатова (етр. Біанки) эта сова

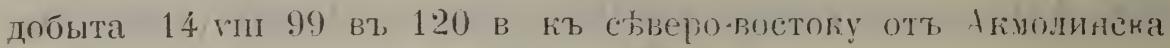
Западно-сибирскіе зкземпяры этою вида отличаютел итъ восточно-европейских болье бльдий основной окраской, полему и выдьлены подъ названіемь pallidus,

\section{Nyctala tengmalmi Gmel. Cuчt, yoxmonoriö.}

По сообщенію П. А. ШІа стовскаго әта маненькя сова попадалась ему льтомт въ окрестностхъ ст. Капнскъ. Въ нашихъ степяхъ экспедиціями не добыта.

Пlo O. F inschy (стр. 147) встрынается подъ ()нском, гды по А. Иорозову (стр. 10) эта coßil, ,ооычная, но не часто встрььчащаяся форма“. По И. Словцову (стр. ㄴ.42) встрьчаетяя, во всей средней пи южнй части Тббольской губ. Вт пос. Ямышевскомъ сычь мохноногій найденъ В. Н. ПІ ло т н и ко в ы и ъ (етр. 4). Вь Когчетавсіомъ убзды добыть этоть сычъ И. Я. Слов цовым в въ сопкахъ около ст. Щучепской 20 го іюля (стр. 139).

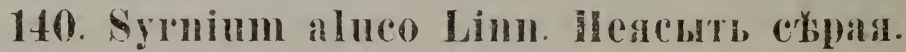

Iо П ал.ласу (стр. 321) эта сова никогда въ Сибири не наблюдалась, но по И. Я. Словливу (⒋3) является самыи обыкновеннымъ видомь пвсной полосы Тобильской губ. Этотъ западно-палеарктическій ридъ приводитея для березовыхъ рощъ юга Тобольской гуо. и М. Р уз ски и ь (стр. 17). Въ наших ь коллекцілхт, экземпияровъ нытъ.

\section{Syrnim lapponicum Retz. Ilescmт, haненая.}

МЕстн. назв. „большая. чецная сова“ (ст. Каинскъ).

Обитательница тайги, эта сова лишь осенью во время кочевоқь замъчела около ст. Каиискъ (по соойщ. П. А. Шастовскаго)

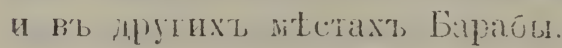


По И. Я. Сливцову (стр. 녀) в’ь пусахь Тюменскаго и Тобольскаго у. ветрьчается круглый годт.

\section{4:. Syrnimm uralense sibiricum 'Tschusi. Hegento

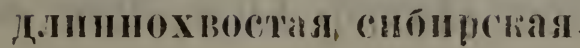

Эта разновидность п.линиохвостой пеяспти, недавно описанная В. фонъ Чузи *) и выдълениая подъ особымт названіемь на основаніи матеріала, дюставленнаго ему мною изъ окрестностей Томска, зимою обыкиовенна, вђроятно, по всему протяненію Барабинской степи. П. А. ІІ а с т о в с ко му она понадалась вт огрестностяхъ ст. Каинскт,

По И. Я С.ловцову. (стр. ㄴ43) найдена иодъ Тюменью, по М. Рузском у (стр. 19) въ сосновыхь борахт, южной полосы Тэбольской губ́. Другихъ указаній нютъ.

\section{- Strix flammea Linu. Cunyxa.}

В. Н. Пло тн иков ъ (стр. 4) сообщаеть, что эта сова въ окрестностяхь пос. Яиышевскаго довольно многочисленна и не. смотря на свой незначительный рость сшрав.лется съ зайцаии

Это сообщеніе является единственнымъ указаніемъ на нахожденіе сипухи въ Западной Сибири. Не мъшала бы провьрка опредъленія!

\section{Vultur monachus Linn. Ipublo черный.}

Мћстн. назв : „жеребятнию“ (дер. Чпстоозерская), ,паде́н• никъ" (с. Ключевое).

Разсказы мбстныхъ зителей уо̆ьдили меня въ томъ, чт.) по временамъ вт, Кулундинской степи появляются грифы. Судя по ихъ описаніямт, я лумаю, что такнми посьтителями степей въ годы падежа лопалей, тиупь которыхъ киргпзами не зарываются, являются черные грифы. А. М. Н и ко льскій (стр. 185) видыль в' коллекціи В. Н. Плоти и ков а энземляръ, уйитый зимою близъ Усть-Каменогорска. К'ь этому виду отпюу и указаніе G. v. H elnuersen'a (стр. 132', наблюдавшаго въ 1834 г. 24-го іюля близъ дер. Саушки нысколько грифовъ близъ павшей лошали. Хотя описаніе цвьта голыхъ частей шеи этихъ грифовт, данне

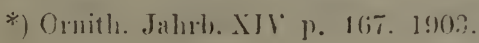


Гели иереенонъ, и не подходить подт, описане у проф. Мензбира, но за, то оно вполн Б согласуется сь описаніемт в'ь новомт

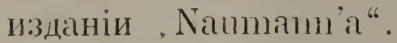

\section{Circus ryaneus Linı. Лунь полевой.}

.Іунь полевой въ јазсматриваемой мьстности, повидимому, встрбчается значительно рьже сородичей, но несомптнно прннадлежитъ къ гнфздяшияя въ ней птицамъ. Его неодновратно наб̆людали во врєма поқздокъ какт по Барибинской степи, такъ и1 вт, Кулундинской, но почему то әкземпляры недобыты.

ІІо И. Я. С л о в ц о в у (стр) 241) әто (амый обыкновенный видъ, распространенный во всей Тобольской губ, въ южной полось которої найденъ и Р узски м ъ (стр 11). Подъ Омскомъ

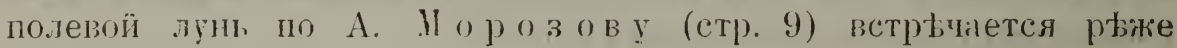
другихь. По В. Н ІІ лотников ! (стр. 3) әтоть лунь в' степи близъ пос. Ямышевскаго чрезвынайпо многочисленъ.

\section{Circus pygargus Linn. .Іун, луговой.}

$$
\text { (= C. (ineraceus Mont.) }
$$

Југовой лунь въ степях нашего грая встрђчается весьма часто. Въ Барабинской степи проф. Н. Ө. К а щ ен ко убиль б.лизт ст. Татарской 16 гі әкземнляръ, въ желуцав котораго мы напли кости маненьюй птички. Вғ окрестностяхъ ст. Коченово этоть лун па пашняхт, быль въ началь іюля очень обыкновененъ; особенно много было тутъ молодыхъ Въ желудкахъ ихъ я находилъ полевокъ и въ одномъ случағ остатки взрослой полевки и 7 ея зародышей. Въ, Кіулундинский степи этотъ лун, найденъ въ огрестностяхь, дер. Плотниковой, близъ цер. Чистовзерский п с. Камышенги, вт, д. Нижній Кучуці и на протяженіи всего маршрута до ст. Семиярстиї

Экземпляры коллекціӥ:

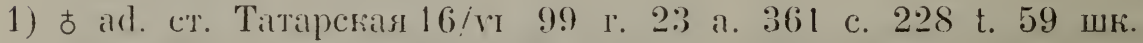

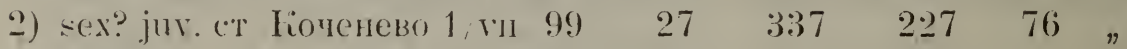

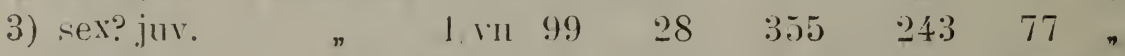

4) sex? jur. \# $\quad 1 /$ vн $99 \quad 26 \quad 335 \quad 228 \quad 29,5$,

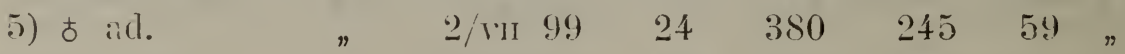

6) sex. jux. - 30 vil $99 \quad 26 \quad 370 \quad 249 \quad 77 \quad$ " 
7) о.јuк. окр г. Барнаула 12 vш 98

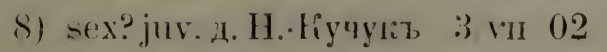

9) q ad. ст. Семиярская 24 ;
25

24

24
$3: 36$

360

360
$2 \cdot 20 \quad 69 \quad$ แแ1

$2.2475 \quad$

$23074 \quad$

Э. Эв ерсманнь (стр. 7 его „Addenda“) угізываетт, на припртынске луга какт, на мыстонахижыценіе этого луня. О.

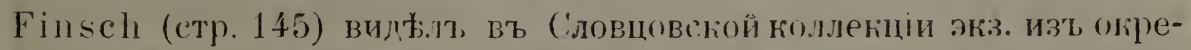
стностей Омска. М. Рузскій (етр. 11, 12 и 16) находилъ этого луня какъ вา, черновемної, такъ, и въ солюпчаковой степи; кром того этотт, лунь, живетт, и въ березовыхъ роцахь южной полосы Тобольской губ., откуда, впрочемт, не прпводится И. Я Словцовымт. По А. Морозову (етр. 9) лунь луговой очень обыкновенен'ъ и многочис:лен, подь Омскомь. Экспедиціею П. Г. Игиатова (см. Бланки стр. 17) әтоть лунь добыть въ 100 в. къ югу отъ Омска и въ Атбасарскомъ у. В. С. Е ли а тьев в ким ъ (стр. 145) добытъ, лиш на сьверн. берегу 0з. Селеты-Денизъ (Омск. у.). И. С ло в ов ни добыть въ Кіккетавскомт, уьзды (етр. 138)

\section{Circus macrurns Gmel. IIуш степной.}

(C. pallidus Sykes)

Лунь степной широк" распространенная въ степной части нашего края птица. Въ Барабинской етеши экземпляры добыты

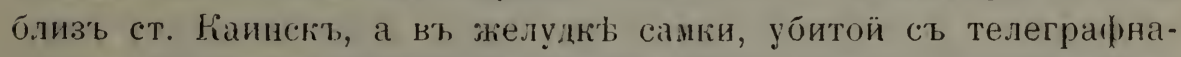
го столба, пюбпмаго нхъ мъстопребыванія. близт ст. Коченево, найдено нбскольк череповт, полевокъ и нижняя половина к.лю. ва пебольшой птички. Въ Кулундинской степи лунь стенной на-

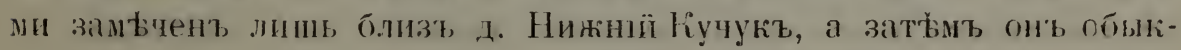
новенен's, по Иртышу близт, ст. Семиярской. Въ окрестностяхь Барнаула этотт, лун, пю сообщенію А П. Велижа и и на неptraliz.

Әизсмпляры коллекціи:

1) 9 arl ст. Кіоченево 30 vi 99 r. 28 а. 360 с. 233 t. 7.5 ши.

2) б semiad ст Каинскт, $30 /$ ги $99 \quad 26 \quad 326 \quad 205 \quad 70$ ”

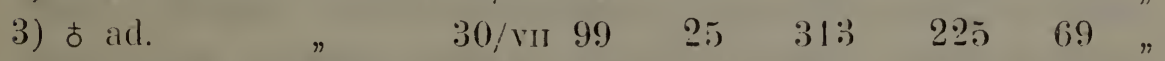

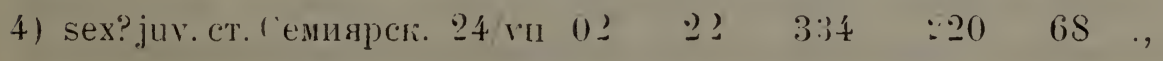

Экземплары 츠 2 и 3 пияютт. 
Размбры и вђсъ одного яйца этого луня изъ окрестностей

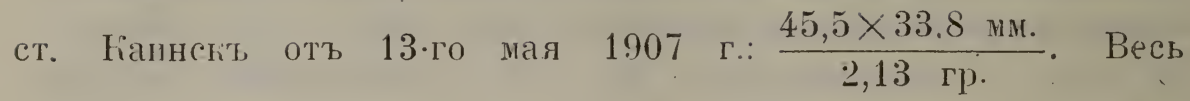
острый полюсъ этого яйца покрытъ рясплывшимся корияневымъ пятномъ.

По И. Я. С ловцову (стр. 241) әтоть лунь залетаеть въ Тюменскій у. очень рбдко. По. М. Р узскому (стр. 11 и 12) онъ найденъ вт черноземныхт и солончаковыхъ степяхт южной полосы Тобольский губ. Под’ь Омскомт, по А. Морозову (стр. 9) обыкновепенъ и многочислент. В' Омскомъ и Акмолинскомт уу. гіромь того добыт П. Г. И гнатовым в (Біанки стр. 17). Шриводится И. С ловцовымъ (стр. 138) лля средней полосы Акмолинской области.

\section{Circus aeruginosns Limn. Jунь қаныневый.}

Мьстн. назв. „утятникт, “ (ст. Татарская), „мышеловка“" (ц. Чистоозерская).

Болотный лунь встрбчается чрезвычайно часто в’ъ степной части нашего края. Въ Барабинской степи онъъ нами найденъ повсем'ьстно. Въ Кулундинской степи это весьма обыкновенный хищиикъ всюду, гдъ есть озера. Въ Семипалатинской области мы его просльдили до станицы Семиярскій. Отъ П. А. ШІ сто вска го я получмт, кладку изъ пяти ненасижіенныхъ яицъ камьшеваго луня изъ окрестностей ст. Каинскь. Гнъздо находилось „Въ камынахъ “ и было найдено 15.го мал 1903 г. Размъры и въсъ почти чисто бълыхъ яицъ, изъ которыхъ одно поступило въ оологическую коллекцію нашего университета, сльвююіе:

1)

$$
\begin{aligned}
& 49,8 \times 38,5 \text { ми. } \\
& 3,25 \text { гр. } \\
& \text { 2) } \begin{array}{c}
49,3 \times 39,8 \text { ми. } \\
3,52 \text { гр }
\end{array} \\
& \text { 3) } \frac{51,3 \times 38,4 \quad \text { ми. }}{3,66 \text { гр. }}
\end{aligned}
$$

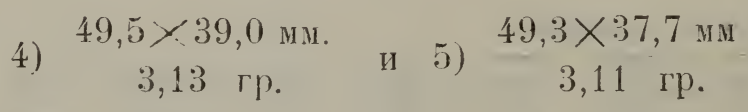

Въ желудкахъ убитыхъ экземпляовъ часто найдены были остатки мелюих'ь птичек'. Интересно, что у самокъ әтого луня въ двухъ случаяхъ (№ 4 и 9) было обнаружіено присутствіе яичника и ст правой сторонь. 
Экземпляры коллекцій:

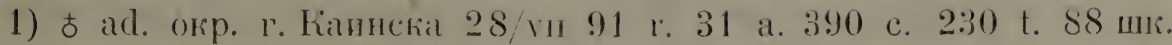

2) sех? оз. Сартлань 22 vil $91 \quad 34 \quad 408 \quad 235 \quad 91$ чуч.

3) 우 ad. ст. Татарская $17 \mathrm{v} \quad 99 \quad 34 \quad 416 \quad 241 \quad 96$ шк.

4) ㅇ ad. ст. liоченево 4 vi $99 \quad 35 \quad 424 \quad 25488$ ”

5) б semiad cr. Татарская 29, v1 $99 \quad 34 \quad 38: 3 \quad 223 \quad 87$ ”

6) t ad. " $\quad 15$ vi $99 \quad 33,5 \quad 400$ 24.5 $81(!)$,

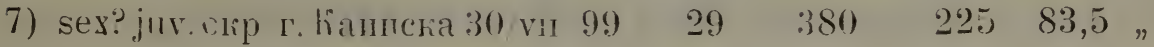

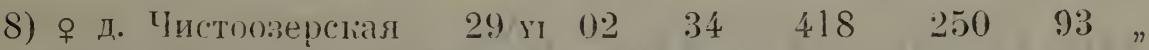

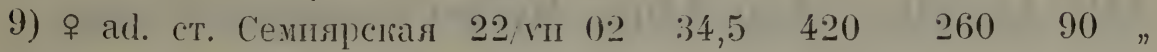

O. Finsch (стр. 145) наблюдалт әтого луня между Омскомъ и Семипалатинскм' изъ ююрестностей Омска экземпляры въ коллекіи И. яІ. слов ІІо в а; здћсь этоть лунь и по свидътельству А. Моровова (стр. 9) очень обыкновененъ Іг многочисленъ. Для Тюменскаго ућзда и юзннй полосы Тобольской губ. этотъ лунь приводится И. Я. С л о в по о вы м ъ (стр. 241) и М. Рузск и м (стр. 12 и 23). По В. Н. П пот н и ко в у (стр. 3) камышевый лунь- „гроза для водоплавающей дичи“-въ изобиліи встрбчаетья въ окрестностяхт, пос. Ямышевскаго. Экспедиціею П. Г. И г натов а найденъ въ Омскомъ и Акмолинскомь уу. (Біанги стр. 18 \%. В. С. Елп атьев ски м ъ (стр 145) приводится для озеръ Омскаго у взда, а_ И. Я. Сл о в ц о вы и в (стр. 138) для Кокчетавскаго уъзда.

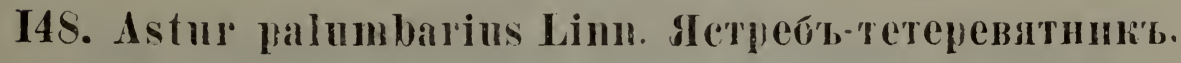

Мжстн. назв.: „ястребъ сњрый“ (ст. Татарская).

Шкурку этого хищника, негодную для коллекціи, намъ пред. лагали пупить нє ст. Убинский вь Барабь. Въ своей западной фору б этотъ хищнике обыкновенная гньздящаяся птица всего Томскаго края. Осенюю и зимою залетають сюда, въроятно, и экземпляры восточнаго происхожденія, извъстные подъ названіем' A. candidissimus i) $\mathbf{y}^{\mathrm{J}}$. (Accipiter astur var. alba Pall). Taкъ, этоть бълый тетеревятникъ добыть въь январ Б 1902 г. близъ

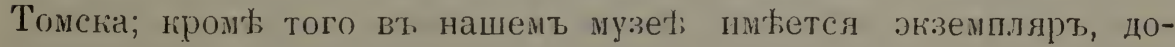
бытый K. М. С ухаре в м ъ въ огрестностяхт, г. Ачинска 24 мш 1901 (ㅇ juv.).

Во время нашихъ побздокъ этоть хищницъ не доб̆ть. О. Finsch (ст!). 145) видъ.лт, вт, Словцовской цоллекціп әкз. изъ 
онрестностей Оиска, гдъ онъ по А. Мо розову (стр. 9) „рьдко встрдчающаяся птица“. Вт, окрестностяхъ пос. Ямышевскаго этоть ястүео̆ы по В. Н. Пло т н и ков у (стр 3) пюпадается теже довольно рылко. По И. Я. С.л о в ц о в у (стр. 238) этоть хищникъ в'ь іюжных частяхъ Тобольской губерніи встрьчается рбже, чъмт, перепелятникь. Найдень М. Р уз кки м ъ (стр. 16) въ березовыхъ рющахъ южной полосы Тобольскпй губ. А. П Вели-

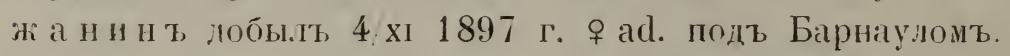

\section{Accipiter nisus Limn. Ястребт-перепе.лятик.}

Во время пођздки перепелятиикъ не попалался, но спорадически распространенъ, повидимоиу, по всему протяженію нашего грая. Блпзъ г. Барнаула онъ добытъ А. П. В ели ж а піи ны м ъ 19 у 98 г. Эквемпляръ изь окрестностей Омкка О. Finsch (стр.

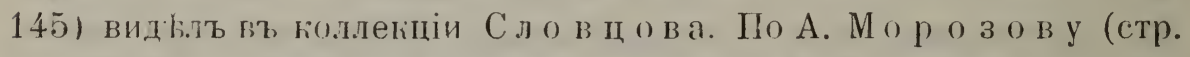
9) онъ поцъ Омскомъ встрђчается рьже тетеревятника. Крайне рьдић перепелятниъ и въ окрестностях пос. Ямыневскаго

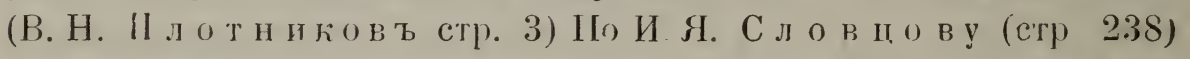
перепелятникъ в' южныхъ частяхъ Тобольской губ. обыкновененъ; здґсь найдень и М. Р у з с к и м ь. Въ Кокчетавскомь увздь найдент И. Я. С ло в ц о в ы м ь (стр. 13今).

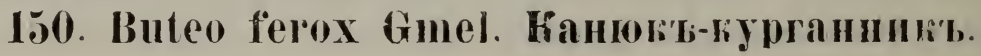

\section{(B. leucurus Naum.)}

Канюкъ-курганиикъ памъ не попадался. О. Finsch'y (стр. 139) кажется, что онь вицљль этого сарыча близъ Семипалатинска, Экспеднціек Іі. Г. И г на то в а (Біани стр. 17) добыт" въ Ак-

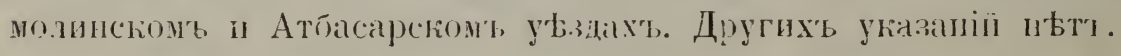

\section{Buteo vulpinus Licht. Сарыт, малый рыжій.}

Этоть сарычь, хорошо извғстиый ины изъ окрестностей Том ска, былъ уоить однимь изъ монхъ спутниковт, иколо д. Плотни-

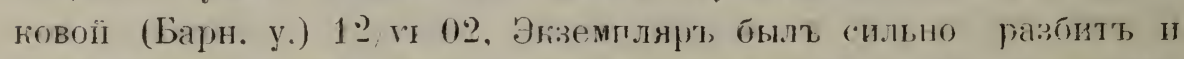
такъ кагъ онъ, повидимому, ничъмъ не отличалея оть томскихъ, то ны, заваленные работою, рышили ег, не препарировать.

По И. Я Сло вцову (стр 241) этоть сарычь доставтенъ

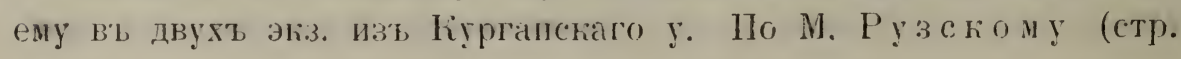


16) встрылается въ березокихъ рощахт, южной полосы Тобольской губо.

\section{? Buteo vulgaris Leach. Caрыты, большой}

По В. Н. Плотникову (стр. 2) этотъ видъ, очень обыкновенная птица, особенно на луговой сторонъ; Иртыша. гды онъ и гнғздуетъ“. Въ точности опредћленія вида сомнъваюсь, потому что другихт указаній па нахожденіе этого именно сарыча въ Сибири не нахожу. Съ такимъ же недов вріемъ отношусь я и къ замбттк' O. F in s ch' a (стр. 139) о Buteo vulgaris Leach котораго этоть изслђдователь „нЊсколько разъ видъль на Ал“ађ“. Здысь әкспедиціею проф. Н. Ө. К а ще н ко найдена черная разновидность малаго сарыча (B vulpinus fuliginosus Menzb.). Невыясненнымъ остается вопросъ, къ какому виду сльдуетъ отнести B. vulgaris Словцова изъ Кокчетавскаго у. (етр. 136).

\section{Archibuteo lagopus Brïn. liaнок' мoxноногій Западный и}

\section{Archibuteo pallidus Menzb. Liнюкь мохноногій снопрскій.}

Оба вида посъцаютъ кашъ край осенью и зимою. Экземпляровъ изъ нашихъ степей ньтъ в' коллекціяхъ. И. Я. С.ловцов ц (стр. 241) приводить его для Тюмени (15 х 83 и 27 1х 90).

\section{Aquila chrysaëtos Linn. Xasвaн'b, берtiуtb.}

\section{(A.nobilis Pall.)}

Мњстн. назв: „беркутъ“ (всюду).

Огромный әкземпляръ эюого могучаго орла питался остатками лошади близъ ст. Калачинской (Тобольской губ.) 25-го іюня 1899 г., но мелкою дробью ничего нельзя было сдђлать. Въ Кудундинской степи намъ не приходилось видбть этихъ орловъ, но по разсказамъ жителей они встрбчаются, нацр., въ окрестностяхт лер. Чистюозерской. Въ приалтайскихъ степяхъ онъ водится по разсказамъ, записаннымъ въ с. Локоть.

O. Finsch (стр. 136) вид'九л въ Словцовской коллекціи эюземпляръ изъ окрестностей Омска. Но И. Я, Словцову (стр. 240), считающаго халзана и беркута за два вица, этоть орель встрђ- 
чается въ Тюменскомь у. юругый годъ, жимю даже чапе, чьиъ льтомт, но гивзлится веснда рьдко. 11 А Морозову (стр. S) беркуть встрђчается чаще другихъ орловъ близъ Омска. А с среднихъ частяхт, Акмолинской об.л. әтоть орелт наблюдался И. Я. С.ловцовымт (стр. 135).

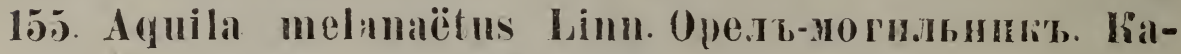 pary\%น.}

(Aqu. mogiluik Gmel.=Aqu. heliaca Sav. $=$ Aqu. imperialis Bechst.)

Мғстн. назв -орель бьлюголовый“ (ст. Татарская). „карагунт, " (с. Киючевое)

Орелъ-могильник'ь довољьно часто встрбчается въ нашихъ степ.хъ. 9.го іюня 1899 г. я вицьлъ въ оғрестностяхъ ст. Уо̆нской (въ Барабю) двухт, могильниковъ. но безъ винтовги не могъ доп̆ть экземпляра. Проф. Н, Ө. К а ще нко

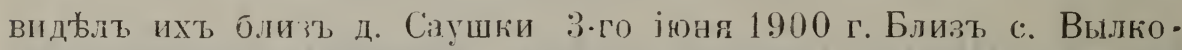
ва (вт Кулундинской степи) и далье вт окрестностяхъ д. Чистоозерской, с. Гілючевого, ст. Семинрсксй мы встртплись съ этимъ орломъ. Въ коллекціи экземплярь, добытый проф. Н. Ө. Каш ен к о въ 1891 г. въ Бараоб. Опредьленіе этого экз. провърено проф. М. А. Мензбир и н

Его измтренія:

sex? c. Tackaebo 2? vi 91 r. 60 а. 603 c. 300 t. 110 шк.

По И. л. Сло в по в у (стр. 240 ) этэтъ орелъ въ Тюменскомь у. лишь залетный, а Бъ Петропавловскомь и Когчетавскомъ уу. гнъздится въ сисновыхт льсахъ. А. Морозовт, и В. Н. П ло тников ъ приводятъ, ошиопчнп этого орла подт пазваніемъ Аqu. naevia linn. Въ окрестн. пос. Ямышевскаго әтоть хищникт, довольні обыкновенень, а подь Омскомъ попадается рбдко.

\section{Aquila nipalensis Hodgs. Opests cremoñ.}

\section{(Aquila orientalis Cab)}

Во время эгскурсіи 1899 г. близь ст. Татарской 24 vг быль убитъ орелъ, которэго приходится отнести кь виду, до сихъ поръ нечасто даблюдавшемуся въ степяхъ нашего края. Форма и рязмыры к.люва вообце, и ноздрей въ частности, заставляютъ 
меня ститат, этить әкз. за nipalensis Hudgs., но окраска птицы,

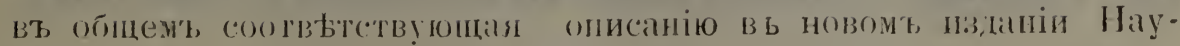

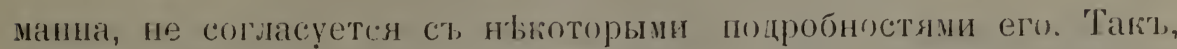

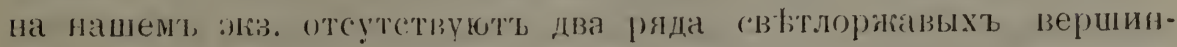
ныхъ пятент, на крогцихт, прыла, приводиныя какъ признакъ взрослыхл. Mатеріала для сравнені, к' сожалынію, у насьь ньтт.

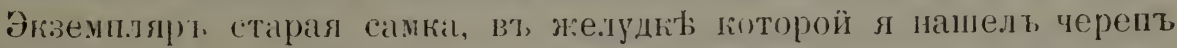
и кости цокора (Siphneus aspalax aspalax Pall.), a въ зобу sпцеpuщy (latcerta vivipard).

Размьри орла: 1.48 а. 528 с. 255 t. 105 . Кромы того измь- . рены: длина залняюо когтя по сииоу $36-37$ мм.; длина средняго пальца 丂ร мм.; длина клива оть угла рта 58 мм., длина ғлюва по сгио́ 63 мм.

По М. А. Мензбиру (стр. 1:36) этоть орелъ найденъ на Тоболь поль 5., с. ш. и на Иртышь, верстахъ въ 150 выше Семипалатинска.

\section{5\%. Aquila clanga Pall. Нодорликъ больной.}

Подорлић большой часто встрьчается въ нашихь степяхъ. Экспедиція проф. Н. Ө. Ка щ ен ко 1891 г. добыла экз. въ Барабъ; въ Кулундинсой степи я во время переђзда изъ д. Чистоозерской въ с. Камышенку видьль 1-го іюля 1902 г. двухъ подорликовъ вт степи. Гньздится въ бору близъ с. Ключевого. Из'ь огрестпосей Барнаула въ моей коллекціи также имъется эгземпляръ.

Измеренія:

1) sex? c. Каргант 1 vi 91 r. $45 . j$ a. 480 c. 275 t. 102 шा: 2) sех? г. Барнауль 20 гш 98 51 530 275101 "

На этикеткъ перваго экз. значится, что оцъ опредћленъ проф). M. А. Мензбо иом н.

По Сл о ц о в у подорликъ льтомъ довольно часто встрђчает ся въ Тобольской губ.; о гнћздованіи его тамъ свђдъній и ьтъ, неизвьстно. также, остается ли онъ здъсь на зиму. В'ь южной полосғ Тобольской губ. онт, найдегъ и М. Р уз ски м ъ. Упоминается А. Морозовымь (стр, \&) для Омска и приводится С ло вц о ымд для Кокчетавскаго уғзда (стр 13ј). 


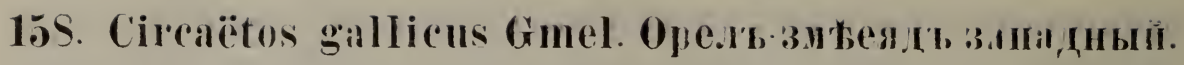

Орелъ-змеяц намъ нигды не попадалея и въ коллекціяхъ экземпляров' нбтю. По проф. Пензбиру (Птицы Рессіи стр. 169 и Sew. et Menz.b. Ornith. de Turk. p. 144) онъ гньздится въ. льсахъ югозападной (ибири къ “вверу до $53^{0}$ с ш. (59 в. выше Пав.юдара). Гсюду рбдкая птица.

\section{HaIiä̈tos albicilla Linn. Oрлань-бълохвость,}

Мвстн. назв.: „бълохвость“ (с. Ключевое).

خкспедиція 1891 г. добыла этого орла на Барабинскихт пзерахъ, но экземплярт, не сохранен',

П. А. Ш а с т о в с и ій сообщаетъ, мнь, что онъ встрбтиль орловь, съь бълыми хвостами близт ст. Каинскъ. Гньздо бъло хвоста мы замбтили на одномъ изъ острововъ на рык占 Оби недалеко отт с. Тулинскаго (Барн. у.) 10 v 02. Орелъ этотъ встрђ чается вт Кулунлинской степи, напр. близъ дер. Чистоозерской, с. Ключевого уетья р. Кулунды, гды мой спутникъ И. М. Кир илл о въ безуспћшно стрблялъ по бълохвосту. Вь Семипалатинской обласли пайденъ близъ ст. Семиярской. Во) время нашего. возвращенія из', ст. Семиярской по Иртышу на пароходы мы 1/ үп вид'ъли орлана-бђлохвоста. По разсказам'ь ветрғчнется онъ и близч с. Jокоть. О. F in s ch (стр. 134) видълъ :того орлана $13 / 1 \vee 76$ на Иртыш и и въ Словцовской коллекціи әкземпляры изт окрестн. Омска. Шо А. М орозову онъ несомнћнно водится по всему (Һверу Акмолинский области, въ Кокчетавскомъ уъздъ которой найденъ и И. Я. С ловцовым з (стп. 135). По В. Н. ІІ лотнин ов у (стр. 1) этотъ орелъ гнъздится близъ пос. Ямышескаго, „но ихъ очень немного“. Вт, Тоболькой губ. по С ло в гов у и Р узскому найден'љ.

\section{Haliaëtos lencorypha Pall. Oparanb-дgodroxвoctт.}

Въ коллекціяхъ экземпляровъ нғтъ. О. Finsch (стр. 136) находилъ этого орлана на Норъ-Зайсаны и Марка-Куль. Интересно соовеніе В. Н: ІІлотникова (стр, 1); что онъ разъ въ 1895 г. убилъ этого орла въ степи на пашнь близт пос. Ямышевскаго, гдъ̆ онъ не является постоянньмъ жителемъ. 


\section{- Milvus korschun Gmel. Liopmym, черпый.}

(M. ater Gmel.=M. niger Briss.)

Эготь коршунт, населяющіиї Киргизскія степи и Туркестанскій грай, по А. М орозов у (стр. 9) обыкновенен'ь и довольнп часто ветреччется подъ Омскомъ. Тоже говорить и В. Н. Плотни иков ъ объ огрестностяхъ пос. Ямышевскаго. И. Я. Сл о вцо в ь (стр. 136) нашелъ его близт, Кокчетавскихъ горъ, (Боровое 0з.). Принимая во вниманіе, что :ттолт коршунъ у другихъ авторовъ не упоминается вовсе, а приводится лишь М. теlanotis, думаю, что названіе лля коршунов'ь, виденныхъ Морозевымъ и ІІлотниковымғ, и добытаго Словцовымъ, взято неудач. но. Экземпляровт въ коллекціяхъ н'ътъ.

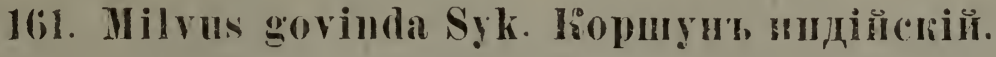

Этотъ көршунъ по В. Н. П лотникову (стр. 2) разъ добытъ близъ пос. Ямышевскаго. Сообщеніе O. Finsch'a (стр. 140) o M. govinda относится безъ сомньнія къ M. melanotis Temm. et Schl.

\section{6:. Milvus melanotis Temm. et Schl. Ropmynt чеpuo- yxilï.}

Коршунт, черноухій часто встрбчается въ нашемъ крађ, но почему-то экземпляровъ въ коллекціяхъ изъ, степей нбтъ. По Оби и Иртышу онъ несомнънно гнъздится. Въ Кулундинской степи гнжздится, напр. близт с. Вылкова.

O. Finsch (стр. 140) наблюдалъ этого коршуна в’ъ Омск'b, Павлодарғ и далье по Иртышу. Спобщенія ІІ ло т н и ко в а и Морозова о М. niger и ater отношу къ этому виду. По С.ловцову и Рузскому этотъ видъ ббыкновененъ въ Тобольской губ.

\section{? Milvus regalis Pall. Lopmyн'b красный.}

O. Finsch (стр. 141), видћвшій въ коллекціи Слов цов а экземпляръ этого вида изъ окрестностей Омска, нё рбшается внести этотъ видъ въ списокъ западно-сибирскихъ птицъ, такъ какъ самъ нигдъ въ Западной Сибири не нахолиль краснаго коршуна, и литературныя указанія о нахожденіи его отсутству- 
ютъ. Лмбопытно, что 20 .Іътъ посль $\Phi$ и нша снова упоиинаетея для Омска красный коршунъ въ качествђ обыкновеннй и довольно часто ветрычающейєя птицы (А. Морозов с стр. 9). Иитересно о̆ыло бы узнать, на чемъ основаны эти сопшенія. Имъемъ ли мы дъло съ храняшимся въ Омскь экземпляром' әтого западно-европейскаго вила, случайпо залетбвшимт или завезеннымт сюда, или опредв̆ленія невбрны? Другихъ указаній в' литературғ, какъ и эквемпляровт въ коллекціяхъ нашихт ньтъ.

\section{- Pernis apirolus Linn: Ocotigh.}

И. Я. Словцовым ъ (стр. 238) особды добытъ въ старыхъ березовыхъ рощахь по р. Пышм' (Тобольской губ.). Другихъ указаній нътъ, равнымъ образомъ нъть и экземпляровъ въ кол лекціяхъ. У П. С. П аллас: а (стр. 359) приводится названіе сургутскихт остяковъ әтого хищника. L. r. Schrenck (стр. 524) говоритъ, что его об́ласть распространенія обиимаеть „ganz $\mathrm{Si}$ birien • (!?).

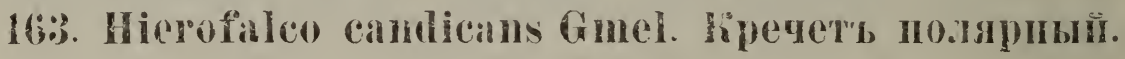

Объ этомь гречеть, залетаюцемъ къ намъ, быть монетьь, зимон, А. Морозовъ (стр. 8) сообщаеть, что онъ указанъ И. Я. Словцовым ъ для Омскаго у'ьзда. Другихъ свъдйній не нахожу. У самого Словщова (1897 стр. 137) не вполнъ ясно сказано, къ какому виду сльдуетъ отнести его кречетовъ, убитыхъ во время поьздки въ Кокчетавскій уъздъ. таиъ какъ онъ, повидимому, названія gyrfalco и саndicans считаеть синонимами.

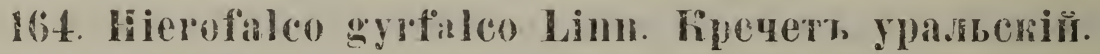

$$
\text { ( - - H. uralensis Sew. et Menzb.) }
$$

По Словцову (стр. 2:37) въ оврестностяхъ Тюмени уоито три гречета этого вида.

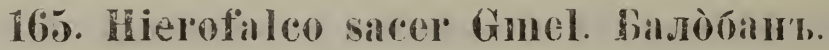

$$
\text { ( = Falco lanarius Pall.) }
$$

Въ Кулундинслой степи моимъ препараторомь М. Т о лмачевын ъ была убита въ сосновомт бору близъ с. Еылкова 18/rт 


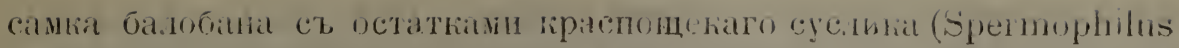

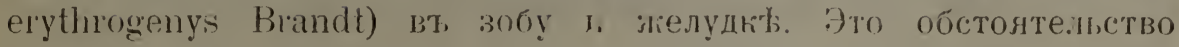
ваставило меня приняться за розысти колынін суслияовь, которая и была наӥдена въ нбсколыних, вецстахт оть, села около небольшого озера. Балобань являетея характерним представителемь авифауны степей кго-запаций Сибнип и предпочитаеть мыстожительством льса, прилегапие пь степят или перемежающіеся со степью, тто ижьеть мысто въ Аулундинской степи. Что hасается его пищи, то иззьстно, что сн', иитается кром' птицт, мелкихъ и крупныхт, и звырками, которыхъ береть ст земли. Изъ доступныхт мић сочиненій только у Н. Н. Сомова (стр. 384) указывается на то, что онт пресльдуеть сусликовъ, у лругихъ жіе азторовъ нахољу лишь указаніе на то, что онт ловитъ мышей. Второй пкземиляръ, старый самець, намъ былъ доставленъ охотиикоми, И. М. Ер е м ье в мъ въ с. Киючевомъ 9 гп. Ноги у него свьтло-сћрыя. Въ зобу и желудкь этого экземпляра также оказа.ись остатки цвухъ сусликовт. Въ предвари-

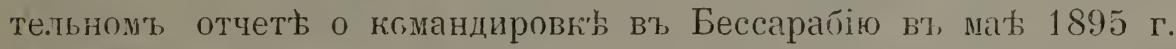
И. К. Т ар на ни сообщаетъ о сусликах' и ихъ врагахъ изт міра животныхъ, между которыми отмьчаетъ хорька и цаплю. Чнсло животныхъ долю счптавшихся, да пожалуй и сейчасьь еще считающихся вредными, но на самомь дьльв заслуживающихь покровительства со стороны человбька, приходится такимъ ооразомъ увеличить еще однимъ-балобаном *).

Әкземпляры коллекціи:

1) ㅇ ad. с. Вылково $18 /$ м 02 r. 31 а. 400 с. 218 t. 62 шк.

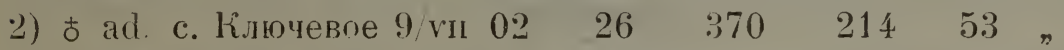

O. F insch (стр. 141) видђль вт С.овцовской коллекціи экземиялт, изъ окрестностей Омска, что чиазываеть на то, что напт хищникъ водитея и въ Бараб в. Јю Й. Я. С.пов цову (стр. 236) два экземпляра убиты вь іюны около Тюмени. М. Рузск ій (стр 16 и 19) находиль балобана какъ въ березовыхъ рошцахъ, таґъ и въ соснөвыхъ борахъ южной полосы Тобөльской губ. А. Мор озов ъ (стр. 8) однсвременно называеть балобана "Повидимону только зимующей фсрэой“ и сообщаеть о нахож-

*) (м. и мою замbтry: .,Woron nährt sich der Würgfalk (Faleo sicer Gmel.)?." Ornith. Munatsschr. $190+\ldots 7$. 
деніи молодыхъ въ іюлђ вблизи гнђзда. По В. Н. Плотникову (стр. 2) близъ пос. Ямышевскаго балобанъ, "трезвычайно рьддокъ".

\section{Falco peregrinus Limu. Cancants типиный.}

Сапсань широко распространенъ на гнбздовь' въ нашемъ крағ, но эгвемплярпвъ въ коллекціяхь всего одинь.

Экспедиція проф. Н. Ө. $\mathrm{K}$ а ше н к о 1900 г. достивита въ нашь музей экземплярт, который не оказался прннадлежашимь ю сльдующему виду, какъ можно было предполагать по мьсту нахожденія.

Измьренія еги:

1) б semiad. с. Гилево 8/vi 00 r. 25 а. $308-306$ с. 166 t. 49 шк.

Въ хвость этого экземпляра заньтна замьна двухъ рулевыхъ новыми.

0. Finsch (стр. 142) только разъ наблюдаль сапсана въ ютепях межіду Омском и Семипалатинскомь. ІІо С лов ц о в у (стр. 236) въ Тюменскомъ округь дерзится цъ.лый годъ и зимою охотится за тетеревами. М. Р у з к і й (стр. 16 и 19) находилъ его в’ь березовыхъ рощахт, и сосиовыхь, борахъ юзной полосы Тобольской губ. По А. Морозову (стр. 8) сапсанъ рьдко встрьчается подъ Омскомъ; въ самомь, Омскь встрљчается зимой во время охоты за голубями. В’ь окрестностяхь пос. Ямышевскаго этотъ соколъ по В. Н. ІІ лотникову (стр. 2) не особенно распространень; гньздуеть въ перельскахъ.

\section{6\%. Falco peregrinus lencogenys Brehm. Cancant, бt- .онценій.}

Экземпляровъ вт коллекціяхь пьть. По шроф. М. А. М е н зби р у (стр. Ј0) область гнђздовья этой географической разновидности сапсана тянется отт средняго Дуная до Алтая и вахватывает' Западную Сиоирг. Другихъ указаній въ доступной мнџ литературь не нахози.

\section{Finleo subbuteo Limm. ЧernorT.}

$$
\text { ( = Hypotriorchis subbuteo Linn.) }
$$

Чеглокъ весьма распространенный на гнћздовь' въ разсматриваемомъ ғ:рағ хищникъ. Экспедиціею 1899 г. въ Барабћ близъ 
ст. Татарссо:̈ добыто два әкземплтра. II. А. Ша стовскій до-

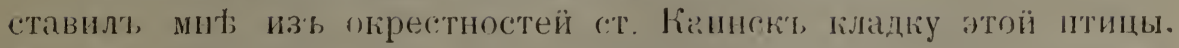

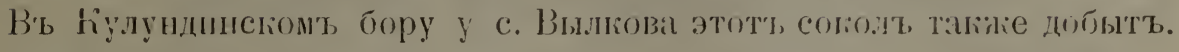
Судя по большому насыднопу иятну это гнтздящаяся здъсь птица. Въ зобу етп оказались остатки шьвчей птицв, канетея Anthus

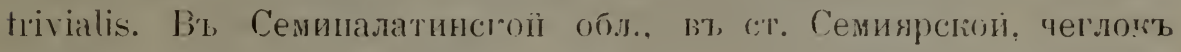

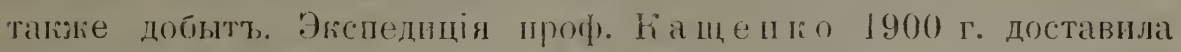
в', напт, музей три әкземпияра этого вида изт, с. Убинскаго и с. Локоть. Въ окрестистяхь Барнаула чеглокт, обынивененъ.

Экземпляры коллекцій:

1) q ad. ст. Татарская 17 ка 99 r. 18 a. 285 c. 160 t. 37 шк.

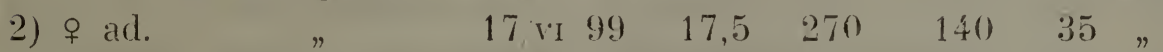

3) t ad. с. Уоинское 26 гі $00 \quad 16,5265 \quad 144 \quad 34 ”$

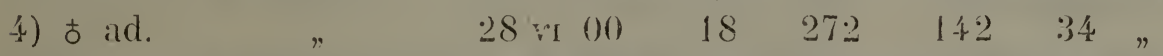

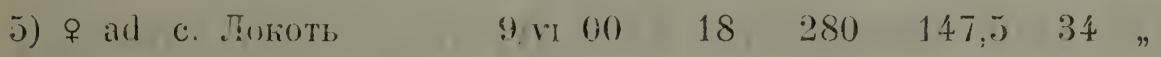

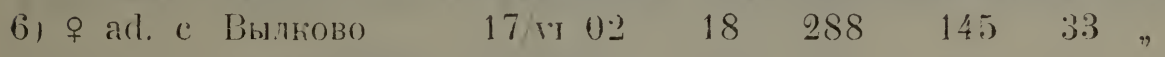

7) 9 ad ст. Семиярскія $24, \mathrm{rir} 02 \quad 19275 \quad 148$ 35 "

Измғренія 3 яихьь этого сокола, взятыхт, изъ вороньаго гньзда 21 мая 1903 г. близъ ст. Каинскз:

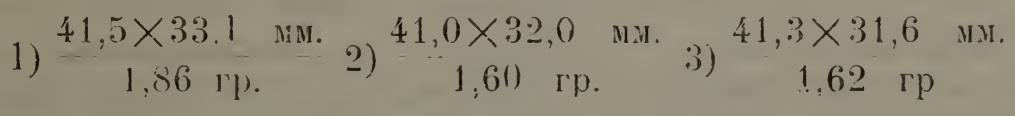

Первое яйцо не только больше и значительно тяжелъе другихъ, но и гораздо темнье ихт.

О. Finsch : стр. 143) видъ̆ллт этого сокола в’ь Словцовской коллекціи изъ окрестностей Омска. Экспедиціею П. Г. Игн ат о ва чеглого добытт въ 60 верстахъ кт, югу оть Омека (В. Б і ан и и стр. 16). По В. С. Елпатьевскому (стр. 145) встрђчается въ Омскомъ ужзды гораздо рыже пуетельги и кобчика.

Въ окрестностяхъ пос. Ямшшевскаго чеглокт, по В. Н. Пл о тников у (стр. 2) довольно пбыкновененъ и гнжздуетъ въ пе рельскахъ.

Подъ Омскомъ чеглокъ по свидительстьу А. М оровов а (стр. 8) встрбцаєтся не особенно часто. И Я. С лов ц о в (стр. $236)$ называеть чеглока самымъ распространеннымъ видомь, соколовт, въ Тобольской губ̄, въ березовыхъ льсахт и сосновыхъ борахъ южно: полосы которой найдент и М. Р у з с ки м. м (стр. 16 \& 19$)$. 


\section{Falco aesalon Linn. Ievónut.}

(Lithofalco aesalon auct. $=$ Falco regulus Pall.)

Въ нашихъ коллекціяхь әкземпляровъ нетт, но зчотъ соколь несомнћнно встрбчаетея въ разсматриваемой мъ̆тности. Въ Словцовской коллекціи $\mathrm{O} . \mathrm{Fins} \mathrm{ch}$ (стр. 143) видыль акз. изъ окрестностей Омска, гдњ дербник по И. Словпову (стр. 137) и А. Морозо в у (стр. 8) встрбчается не часто. По Иртыпу близъ пос. Ямышевскаго найденъ В. Н. П л о т н и к о в ы м (стр. 2), но встрьчается сравнительно рьдко. По И. Я. Словцову (стр. 236) дербикъ попадается преимушественно въ юю-западной части Тобольскої губ, но уоить и близъ Тюмени. М. Рузск ій (стр. 16) находиль его вт, березовыхь ропахт, олной полосы Тобольской губ.

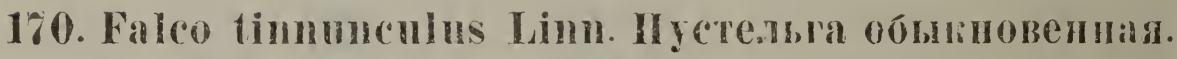

(Timnunculus alaudarius auctor.)

Пустельга весьма обыныовенна въ степвхт нашего края.

Въ Барабинской степи мы ее находили близт ст. Убинской, въ березовой рошб около Убинскаго озера, въ окрестностяхь ст. Татарскойі и близ'ь ст. Јаинск'ъ. Въ Кулундинской степи

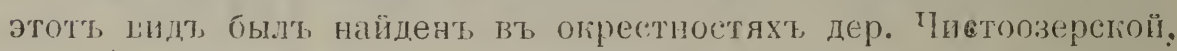
въ бору бзизт с. Ключевого. Проф. Н. Ө. К а щ е н к о доставилт әғземпляр изъ с. ปюкотн. Въ окрестностяхь Барнаула об́ь:киовенна.

Экземплары коллекцін:

1) sex? juv. г. Каинскъ 29 vі 99 r. 15 а. 240 с. 168 t. 38 ши.

‡) sex? juv. ст. Тагарская 28 vi $99 \quad 16 \quad 2050144 \quad 39$ *

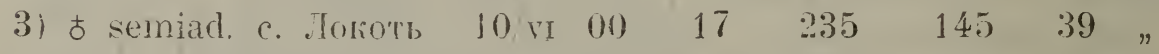

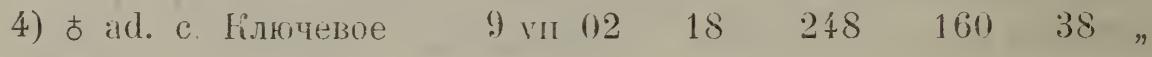

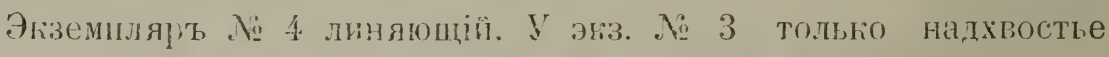
chpar швыта, а гилова и рулевыя еще рыжія.

II. А. III а с т ов с ғ і ӥ доставилт, ми б и:з оюрестностей ст. Саинскт, два лйца, взятыя 21-го мая 1903 г. Размђры и вбеъ ихт:

$$
\text { 1) } \left.\frac{42,0 \times 33,5}{1,79 \text { мм. }} \text { и } 2\right) \frac{41,5 \times 34.0}{1,82} \text { гі. }
$$


Ги'эдится пустельга въь старыхъ гнђздахъ воронъ, сорокъ, а иногда и на земль. Два яйца ея, найденныя на земль П. А. ІІ а -

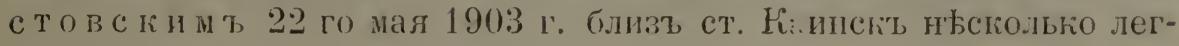
че первыхт:

$$
\text { 1) } \frac{42,4 \times 31,5 \text { мм. }}{1,60 \text { гр. }} \text { и) } \frac{42,0 \times 31,5 \text { мм. }}{1,63 \text { гр. }}
$$

Подт Омском, пустелюга обычная форма всюду, въ особенности по опушкамъ березовыхт ғолковъ (А. Норозовт стр. 8). liъ югу оть Омска наблюдали ее O. Finsch (стр. 143), В. С. Е ллать евскій (стр. 143) и П. Г. Игнатов в (см. Бі ании (стр. 17). Въ окрестносгяхъ пос. Ямышевсгаго эта пуетельга по В. Н. П.ло ти и ко в у (стр. 2) чрезвычайно обыкновенна, но странно, что степная пустельгі этимъ авторомь не упокинается вовсе. Для Тобольской губ. приводится И. Я. Словцовым т и М. Рузским и, для Кокчетавскаго уғзда И. Слов повым ъ (стр. 137).

\section{1\%. Farco namanni Fleisch. Iyctesbra creman.}

\section{(Tinnunculus cenchris Naum.)}

Степная пустельга, отличаюпаяся оть опыкновенной пустельги во всякоиъ вограст бо бблыми когтями, гивздится въ, южныхь частяхъ вашихъ степей. Во время поғздки въ Һулундинскую степь п прилеганщія мбстности я записаль, въ свой дневникъ с. Ключевое и ст. Семнярскую, какъ мьстонахожденія этого вида. Въ, обыпхъ случаяхт мы имъли дъло съ молодыми экіземплярами, доставленными намъ и жившими у наст; жаль было изъ нихъ приготовить шкурки. Такимъ образомь, наши коллекціи и не имъют”ь представителя этого характернаго вида.

O Finsch (стр. 133) находитъ, что степная пустельга встрбчается вљ напихт степяхъ рбъте обыкновенной. Онъ находилъ ее въ степи между Омсконъ и 'емипалатинскомъ. И. Я. Слов г о в ъ и М. Д. Руз скі й приводятъ ее для Тобольской губ. По А. Морозову (стр. \$) степная пустельга не разт была встрьюена въ Омскомт у. Экспедиціек П. Г. Игчатова әтоть соколъ бытт добытт, въ Атбасарскомъ и Коктетавском' у. (В. Б і а н ки стр. 17). Но уже раньше всъхъ упомянутыхъ авгоровъ 
E Eversmann (стр. 6 его Addenda ad celeberrimi Pallasii и т. д.) писаль объ әтомъ видь „nес non in campis herbidis ad fluv. Jrtysch".

\section{7\%. Falco vespertinus obsemus Tschusi. liormmk' теиный.}

(Erythropus respertinus auct.)

М安тн. назв.: „скопчикъ“ (ст. Убинская, ст. Татарская).

В. фонъ.Чузи недавно *) описаль западно-сибирскихь побчигксвъ, доставленныхт ему мнюю изъ окрестностей Томска, и выдълиль ихт въ качеств' оспбапо подвида всльдствіе ихъ въ опщемъ больве темной окраски (むᄒ), зам'ьтнй на разныхъ частяхт оперенія

โобчикъ въ степяхъ нашего края весьма обыкновенная, гићздящаяся птица. Въ Барабинской степи мы находили его вблизи ст. Убинской, Каинска, ст. Татарской и ст. Коченево. Близт ст. Убинской проф. К а п е н ко 12 ш 99 впдъль кобчика съ полевкою въ когтяхъ. Кобчикй вообце встрђ чаются очень часто, иногда ґълыми семьями, усьъвимися на телеграфной проволокь, откуда слтдятъ ва добкчей.

Въ Кулундинской степи кобчикъ также пироко распространенъ на гнъздовьъ Мы находили его въ роцђ-боркб близъ дер. Плотниковой, въ расположенныхъ среди степи березовыхъ и ивовыхъ ћолкахъ. Вмъстђ съ сизоворонками кобчики усаживаютея на кольяхъ по дорогамъ, напр., между с. Тюменцевымъ и Вылковымъ, межлу д. Мысы и Чистоозерской; вл окрестн. д. Чистооверской кобчикъ обыкновененъ. Близъ с. К.ґчевого въ степи мионество койчиковъ сидъло за неимьніемт болье возвышенныхъ мъсі" на травянистыхъ растеніяхь изъ зонтичныхъ и др. Въ Семипалатинской обл. кобчикъ также весьиа обыкновенен'ь. Экспедиція проф. Н. Ө. К а щ е н Іі 1, 1900 г. доставила въ нашъ музей экз. изъ д. Саушки.

ВТ, моей частной коллекціи әкземпляы изъ с. Тулинскаго на Оби и изт окрестноетей Барнаулі, пзмџренія которыхъ я также помшщаю здйсь:

*) Ornith. Jahıbuch. XV. 1904 (тp. 229. 
さкземпляры жольекціи:

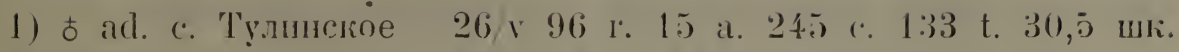

2) \& ad.

$26, \times 96$

$16,3 \quad 246 \quad 1: 37$

30

3) о јuу. г. Барніауль 12 vim 98

$14 \quad 217$

120

30,5

4) б semiad. ст. Кочен. 2 vil 99

$17 \quad 23:$

140

30

5) s sem!ad. ст. Каин. 29. vı 99

$17 \quad 2: 5$

127

$30 \%$

6) q semiad. ст. Татарек. 17 г 99

16

230

130

30

i) o semiad. дер. Cayшка 2/vi 00

$16 \quad 235-238 \quad 133$

29,5

8) ad.

$4 / \mathrm{S} \cdot \mathrm{I} \quad 00$

$15,5 \quad 230 \cdot 250 \quad 134$

29

9 ) ad. дер. Ключи 15 у 02

15

238

136

30 "

10) sex?.juv. ст. Семияр. 28 кп 02

77

$29,5 \quad$

За неимғніемъ матеріала западно-європейскаго пропсхожденія я пе могу провьрит, указанных В. форонт,-Чузи отличій западно-сиоирскихъ кобтиговъ оть европейскихъ. Экземпляры, нашей коллекціи интсресны вт, томь отношеніи, что показываштъ всевозможныл степени окраски. Такъ, эгз. ․ㅡ 3 мололой въ первомт перь, вполнь подходящій подт, описаніе проф. М. А. Мензбира (стр. 28); № 2 старая $q$ ст, густо-рыжей нижней стороной, свбтльюшей гъ зобу и горлу. № 8 старая $q$ съ чистобылымъ горломт. № 7 самка ст бльдно-рыжей нижней стороною и темными наствольными плтнами. 스 6 пючти тождественъ съ

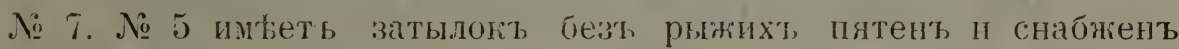
черными наствольыми пягнами в'b виды тонких черточект на пепельносизыхъ пеюяхт, которыя нбсколько свьтлье, чьмъ у старыхъ むᄒ, напр., у экз. № 1. Два среднія рулевыя черносизыя безъ поперечной предвершинной полосы, какт это описывается Мепзбироиъ (стр. 29). Остальныя рулевыя со многими поперечными полосани темнаго и сыргвато-рыжаго цвђта. Вь хвость этюго экземпляра два крайнихь рулевыхъ съ львой стороны замънены новыми, одняцвыными, темными безл, пюлпељ, недостигшими впрочемъ еще окончательнй длины. Съ правой стороны әтой замбны перьевъ новыми не вядно. Серебристый налетъ на маховыхъ выраженъ слап̆о и болье замьтень на второстепенныхъ изъ нихъ. У экземпляра 스 4 на затылкћ видны рыжія пятна. Десять рулевыхъ съ терной шијокой предвершинной полосой, отсутствующей на двухъ крайнихъ. Всь рулевыя чернлсизыя. Перья зоба почти всђ рыжія, часть ихъ пепелыныя, брохо пєпельнее съ черными стволівии. 
Изъ окрестностей с. Тулинскаго вљ мей юоляекціи цва яйца кобчика, взятыя 26-ге мая 1896 г. Разиьры и вйе ихь:

$$
\text { 1) } \frac{36,5 \times 28,0 \text { мм. }}{1,04 \text { гр. }} \text { " } \frac{38,0 \times 28,0 \text { мм. }}{1,15 \text { гр. }}
$$

Изъ Бараб̆ы (окрестногти ('т. Каннскъ) одно яйцо, взятое во

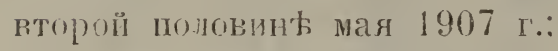

$$
\begin{gathered}
35,2 \times 29,0 \text { мм. } \\
1,29 \text { гр. }
\end{gathered}
$$

По литературнымт, данным кобчикъ весьма обыкновененъ въ нашихь степяхь. O. Finsch (стр. 14f) наблюлаль его близт Павлодара и видялт, вт, Слошцовской коллекуіи экземпляры изт,

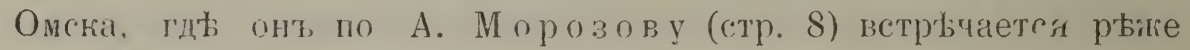
обыкновенной пустельги. Для Омскаго у. приволится и Елп а тье в ски и ь. Близъ пос. Ямыневскаго онъ по В. Н. ІІ лот ников у (етр. 3) гнбздящаяся Вт, старыхъ, вороньяхь гнь:здахт, птица и встрьчается чаще цербника. Для Юобольской губ. указанъ И. Я. С лов цовы и (стр. 236) и М. Д. Рузскимь (стр. 16, 19, 21); въ Акмглинскол огі. по И. С.ловц сву (стр. 137) „саный распространениый видъ, .

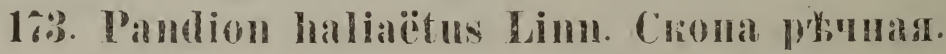

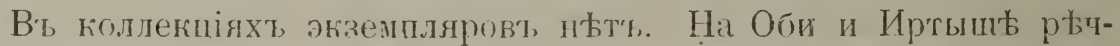
ную скону видтли мы ньскольк разъ во время нашихъ по бздокъ. На степныхъ озерахъ намъ, этоть хицникъ, не попадался, но И. С лов ц о в м ь (стр. ¿235) указано нұсколько озеръ въ Тобольской у б., на которыхт, бнли убиты сколы. O. Finsch (стр 138)

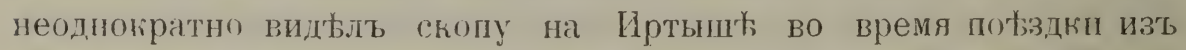
Омска вт, Семиналатинсь, причемъ по его даблоденіямт скопа часто отдыхала на телеграфныхъ столбахт вь степи, По А. морозову (стр. \&) скопа нерьдко встрьчается подь Омскомъ нацъ Иртышежь и надъ озерани. Близь пос. Ямышевскаго скопа льтомт встрғчается по В. Н. II лотникову (етр. 1) весьма

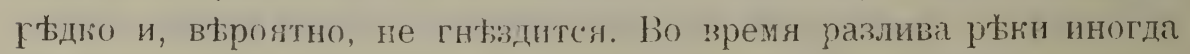
попадается въ значите.нномъ количесть, иногда же ея вовсе нђтт.

Въ Кокчетавскомь уызды рьчнук скопу И. Я. Словцов ъ (стр. :36) находиль, лишь около ст. Шученской, по озерамъ Шученскому и Боровому. 


\section{COLUMBAE (Голуби).}

\section{Columbit rupestris pallida Rothsch et Hart. A.tain- скій сизый ro.ıу⿰ь.}

Алтайскій сизый голубь выдћлеп В. Р отши.и домт и Э. Гартертомъ въ 1893 г. ${ }^{*}$ ) какь самостоятельный нодеидт, оть даурскаго, описаннаго Палласом скаго тьмт, что брюхо и ннжнія кронщія хвоста значительно блғднъе, а середина брюха дажке пити чисто-бљлаго цвъта. Въ нашей коллекци имьется два әкз, цоставление степной экспециціею проф. Н. Ө. Каще нко въ 1900 г. изъ дер. Саушки. Вт, Кулундинской и Барабинской степяхъ пе наблюдался.

Измтренія:

1) $+31, r 00$ r. 18 a. 224 c. 126,5 t. 29,5 шк.

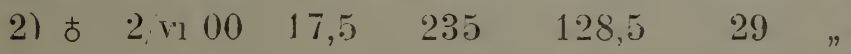

у обоихъ экземпляровт, зобъ и передняя груди съ веменоватымъ металлическимъ блеском $\mathbf{y}$ сильнымь винным . оттђнюмъ. Въ орнитологической литературь Алтая этотъ голубь упоминается почти всъми авторами подъ названіемъ Col. rupestris Pall., въ литературь степной части нашего юрая ншкакихъ указаній на нахожценіе этого голуо̆ нытт.

\section{Columba livia domestica anct. Tosyón дonamuin.}

Какъ вездљ въ русских селеніяхъ полудиіе го.туби встржчаются и въ селеніяхь всей степной части нашего края. Всь эю экемпляры съ бфлымь надхвостьемъ.

\section{Colmmba oenas Linn. Kinmtyx's.}

Клинтухъ представ.яетъ нъкоторый зоогеографическій интересъ судя по литературнымъ даннымт Между тьмъ каюъ даже такіе авторитеты, какъ проф. М. А. Ме нзбир'ь отрпцають его гнбздованіе в’ь Западной Сио̆ири (стр. 582 „Птицы Россіи“), уже

*) (is. Ornitholog. Monatsberichte I 1898. crp. 41. 
О. Finsch въ 1879 г. пишеть. что видылт в’ коллекціи И. Я. С ло вцо ва (ср. Пут. записки стр. 150) экземпляры изъ окр. Омска и чтп этоть голубт, „bisher nicht in Sibirien nachgewiesen " (стр. 229). Затымъ ст, одной стороны А. М о розовъ (стр. 7) говоритъ ,укарань И. Я. Словцовымъ для Кокчетавскаго уызда; въ Тюкалинскомъ окр., Омскомь и Петропавл. уъздь., вњроятно и въ Павлодарсіомъ ", а ст другой В. Н. Плотниковъ (стр. 12), приводя киргизкое названіе „гептерь“, указываеть на уроч. Чибунды, гды встрбтилт ћлинтуховт в'ь значнтельномъ количествь, и на уроч. Матень, гдь удалось убить одного клинтуха въ талахъ. П. А. ШІ астовскій, возвратившись сь одной повздки въ Каинскъ, сообщиль мнь, что встрьтиль тамъ голүбей, поторыхъ

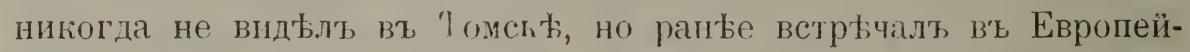
ской Россіи, Когда я сталь ему показывать таблицы въ ногомъ изданіи Наумална, онт, остановился на таблицы, изображающей С. nenas и сказалъ, тто видъль этого именно голубя.-Я думаю, что всђхъ этихъ данныхт достаточно, чтобы отвести нысколько мьста в', этой работь' клинтуху, область распространенія когораго, вьроятно, расширяется на востокь.

Въ нашихъ коллекціяхъ ни одиого экз. не имыется.

\section{Columba phlumbus Limu. Baxирь.}

Относитегьно вяхиря мы имемъ уже со времент Палласа (стр. 56.3) укаганіе что :теть голубь -in Siliria rarissime occurrit; Messerschmidtius tamen ad Ketam ef Jeniseam observatas commemorat". Новыйнія изсльдованія подтвердили лишь нахожденіе эгого голуб́я отъ Урала до Иртыша въ Западной Сибири, а именно Finseh (стр. 229) и словиовъ наблюдали его подт Ялуторовскомт, і Тюменью, а А. Морозовъ (стр. 7) сопбщаетъ, что пнь „встрьчается въ, Омск. у., но очень рьдко“. В. Н. Плотниковы мь вяхирь не приводится вовсе и намъ во время нашихъ повздокт, не попадался.

\section{- Turtur orientalis Lath. Bocromna ropduщa.}

Подъ названіемъ Columba gelastes Temm. эта горлица приводится И. Я. Словцовым т, (стр. 150) для Кокчетавскаго у. Добыта по Словцову верстахт въ 20 отъ Омска. Другихъ ука-

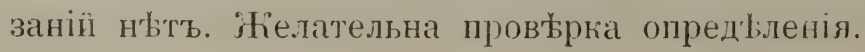




\section{T'urtur ferrigo Eversm. I'olnuma crenhas.}

Самымт, распространениым диким голуоремь пе только в’ь степной части пашего ғрая, но и в', таељной и на Алтаь, является горлица стенная, облхсть распространенія которой обнимаеть Туркестань, Алтай и ирилегаюыя части сибирской равнины, дохоля к'є сћверу до Ннрыма*) вт Томской губ., и до Тюмени въ Тобольской по Словцов у**). Вь Курганскомъ у. по М. Р узском обыкновенної (Т. tırtır). Вт, Барабинской степи мы находили ее повсенғстно вдоль линіи жі. д., начиная со ст. Коченево до ст. Татај)сой. Њт, Кулундинской степи әта горлица такле весьма обыкновенна. Наконецъ, изъ приалтайскихь степей экспедиція проф. Н. $\theta$. К а щ е и о доставила вт нашъ музей три шкурки.

Измғренія экземлляров'ь коллекціи:

1) む ad. с. Jокоть 16 , ri 00 r. 18 a. 199 c. 133 t. 27,5 шк.

2) б ст. IIульб́a $22 / \mathrm{vr} 00 \quad 16,5 \quad 198 \quad 1: 3126$ "

$\begin{array}{lllllll}3) & \text { ㅇ } & & 15 & 195 & 125 & 25\end{array}$

4) б ad. с. Вылюово 17, v $02 \quad 18 \quad 219 \quad 144 \quad 27$ *

5) 우 ad. " $\quad 19$, vi $02 \quad 18 \quad 200 \quad 141 \quad 27$ "

Для степеӥ Кокчетавскаго уъзда И. Слов цо въ (1897 стр. 150) приводить Col. turtur Linn. (Вғрно ли опредъленіе?).

*) Смотри В. А. н и жи и ь. (тчеть стр. 9J.

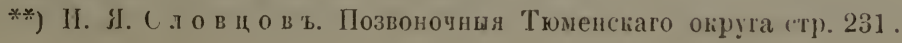




\section{PTEROCLE ES (Ряґки).}

\section{Sypraptes paradoxus Pall. Cаджа-больдерюкы.}

Мьстн. назв.: „бульдерук“ (киргизы стан. Семиярской).

По сообщенію А. А. А р гуно в а саджи иногда появляютея въ окр. г. Каинска. Наиъ о нихъ говорили въ ст. Семиярской на Иртышь, какъ о встрбчающихя въ степяхъ преимущественно по львому берегу Иртыша. Нами не добыты. Въ литературь указаній нбъть.

\section{Pterocles arenarius Pall. Чернобрroxiй „ябокт.}

По) F i n s c h’y (стр. 2231) чернобрюхій рябокъ вь окр. Семипалатинска очень обыкновенное явленіе. Нами на Иртыш' не добытъ. 
V1. GALLINAE. (Куриныя).

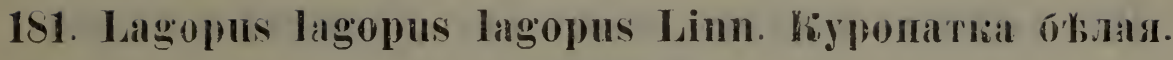

$$
(:=\text { L. allous auct. })
$$

Бдлая куропатка оченг обыкновенная осьдлая птин Бара. бинской степи. Только что убитый әгіз. я видђль у Л. Ю̈. Н о-

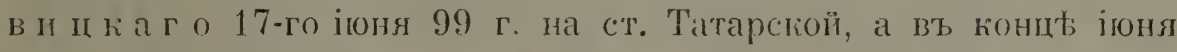
я тамъ же люоволся у С. А. Погож ев а молодой куюопаточкою. содержавшейся у него ит неволь. Ужіе съ мбеяцъ, повицимому. хорошо переносилт птенецъ и заключеніе въ комнать и непривычный кормъ. При мнъ штица усердно клевала мухъ на окнъ. Отъ П. А. ШІ а с т о в с ка ге я получилъ найденное въ огр. ст. Каинскъ яйцо бълой куропатки, взятое 1 б-го мая 1904 г. Въ, гнбзды было всего пдно яйцо. Его размtры и высъ:

$43,2 \times 30,6$ мм.

1,96 гр.

вилъ мнб кладку изт, пяти яицъ со ст. Кожурля.

Измғренія ихъ:

$$
\begin{aligned}
& \text { 1) } \frac{43,0 \times 31,0}{1,60} \text {; 2) } \frac{43,0 \times 30.7}{1,63} \text {; 3) } \frac{42,3 \times 31,0}{1.64} \text {; } \\
& \text { 4) } \begin{array}{c}
42,5 \times 30,8 \\
1.59
\end{array} \text {; 5) } \frac{41,0 \times 31,0}{1,62} \text { мм. и гр. }
\end{aligned}
$$

Кромғ большаго въса скорлупы яйцо, взятое въ 1904 г., отлитается оть яицъ дальньйшаго сбора и болье свттлою окраскою,

Что касаетсл Кулундинской степи, то положнтельныхъ доказательствъ нахожденія ея тамт мнь не пришлось добыть. ІІо сообщенію мћстных'ь охотниковъ она встрбчается у дер. Плотниковой и около дер. Чистоозерской, с. Һиючевого и въ Семипалатинской обл. близъ станц. Семиярской. Намъ во время нашихъ экскурсій не попадалась, а также и не была достивлепа. 
По М. Д. Р у з ско м у она населяетъ южную полосу Тоболь ской губ. (subsp.?), по А. М орозову встрбчается повгембстно въ сьверной части Акмолинской собл. и въ Тобольской губ̆., по В. Н. Плотн и ко ву встрьчается „вт, очень большомт, количествь“ близъ пос. Ямышевскаго на Иртышб.

\section{8\%. Lagopus lagopus major Lor. IPyonatia otya б().J1,Hass.}

Недавно появившаяся въ печати замћтка $\Theta$. Л . р р н ц а *) о новомъ подвидъ бьлой куропатки изт Акмолинска, Орено́рга, Тургал и Омска, но недоставленномь ему изъ Томска, ваставнла меня позаботиться $n$ полученіи нжсколькихь экземпляровъ изъ названной мьстности. Г-ну ПІ. О. ІІІ уль д ъ я и здђсь позволю себ́ћ выразить искреннюю благодарность за присланные имъ мнъ въ мерзломъ вндь 2 әкз. фя изт окр. Омска, препарированіемъ которыхъ я самъ занялея, чтобы при опредъленіи пола не пропзошла ошибка.

По $Ө$. Л о ре н ц у вновь описанный имъ подвидъ от.иичается отъ типнчныхъ күропатокт:

1) бо̀лышими разм рами (явторт, только сообщаетъ размтры бы).

2) болье свЋтлою окраскою льтняго оперенія.

3) болье тємной, почти черной окраской стержней большихъ маховыхт.

4) у очень многихъ, особей концы первыхъ маховыхъ испещрены чернымп пятнышкамп, пли вполнь черны. Эта оюраска видна во всягое время года; она рбдко наблюдатось .Торенцомъ у типичной формы.

5) болте свЋтлою окраскою рулевыхъ, которыя у типичной формы чернаго цвъта. Два среднихт рулевыхъ у новой формы очень часто пмыютъ лишь оิьлье. концы, а не совершенно бълы, какъ у тะпичной формы. Эти среднія рулевыя на большеї части своей длины темно-коричневаго цвтата.

6) въ зимнемъ опереніп сохраняются на головъ, шељ, иногда и на спинљ темныя иятна; основная часть этихъ перышекъ ржавобураго цвђта съ чериыми пятнами.

*) Th. Lorenz: „Lagopus albus (I..) nov. subsp. major." Ornithol. Monatsherichte Xl 1904. (1p) 177 . 
7) біологія: новая форма живеть вт степяхь ст, березовыми льсочками; поздней осенью и зимюю питается не почками и въточками ивъ, какт, типичная, а зернами овса и пшеницы, которыя беретъ со скирдт вт степи. За неимннемт, этихт, зерент питаются почками березт, почему часто какъ тетерева сидять на перезахт

Моп два экземпляра, полученные изъ Чмска, въ зимнем перь не принадлежать къ тииичной формғ. Кт сожальнію объ самки, a потому размьры ихъ менъе данныхъ у $\Theta$. Лоренца (бठ), но болъе данныхъ въ новомъ изданіи „Наумана“ (стр. 51).

$\begin{array}{lllllllllll}\text { 1) } & \text { 9 } & 24 / \text { II } & 05 & \text { окр. г. Onска } & \text { r. } 23 & \text { а. } 210 & \text { с. } 135 & \text { t. } 42 \\ \text { 2) } & \text { † } 24 / \text { II } & 05 & & n & 20 & 210 & 132 & 40\end{array}$

Первый экземпляръ я считаю за самку вновь описаннаго подвида. Въ пользу этого говорятє всь⿱ перечисленныя выше въ п. 3 , 4 и 5 особенности окраски, при чемт концы первыхъ двухъ маховыхт, съ каждой стороны (въ особенности 2-го) не сплошь черны, а лишь густо обрызганы темнымъ. Зобъ у этого экз. былъ совершенно пустой.

Второй экземпляръ предетавляетъ переходную форму отъ типичной къ новой. Кончики первыхъ маховыхъ чистобълы. Особенный интерест, этоть экз. представляетъ въ томт отиошеніи, что изъ двухъ средиихь рулевыхъ правое бураго цвъта съ бълымъ концомъ (перо major Lor.), а лъвое все чистобълаго цвъта (перо lagopus Lim.). Это правпе перо на 34 м.. (считая по стержню) бъл:аго цвъта, между тьмъ какъ у перваго экземпляра бълые концы срелнихь рулевыхъ не шире 16 мм. (по стержню пера). Зобъ у второго экз. былъ набитъ зернами пшеницы. Благодарл любезности $\mathrm{K}$. О. 3 ил пин га я получиль двъ бълыя куропатки въ зимемъ опереніи (бы) изъ окр. г. Шадринска (Пермской губ.). Одинъ экз. несомньнно типичный, но другой также переходнаго харағтера. У него оба среднихъ рулевыхъ совершенно симметрично оқрашены въ основной половин в въ коричневый цвљть, а в’ь концевой части в'т, бълый. На томскомь базарж я пріобрђлъ әкземиляръ съ ивкоторыми особенностями окраскіи тајог, неизв'Бетно гд'ъ уобитый.-Новый подвил'ь включаю въ списокь птиць степной части нашего края, потому что увърент, что они, встрбчается вт западныхъ его частяхт). 


\section{5:3. Tetrao tetrix viridanus Lor. Teтеревь степной.}

Въ Барабинской степи эта разновидность тетерева очень обыкновенна. Мы находили его около ст. Убинской, въ окр. Каинска. Въ Кулундинской степи тетеревъ также гньздится; по сообщенію Ф. А. Шадр и на онъ встрьчается въ окр. д. Плотниковой, но намъ здьсь не быль доставленъ. Далье онъ обитаетъ, степи въ окр. д. Чистоозерской, с. Ключевого. Присутствіе тетеревей мы просльдили до конечнаго пункта нашей поъздки 1902 г. станицы Семиярской на Иртышьь.

\section{Tetrao tetrix ischusii Johansen. Teteneв'ь тонскій.}

Эта форма тетерева, описанная мною*) изъ окр. Томска, найдена в’ Барабинской степи около ст. Татарской. Кулунцинскій боръ у с. Вылкова служитъ также мъстомъ его обитанія и экземпляръ, доставленный мнғ здъсь я считаю за форму переходную къ установленному мною подвиду. Это была тетерка съ большимъ насъднымъ пятномъ. Крайнія рулевыя при основаніи имьли бълыя пятна, между тьмъ какь средніе рули были окрашены какъ у типичной формы. Я отказался шріобрьсти эюз. для нашей коллекціи, такъ какь опереніе, сильно изношенное и поврежденное выстрьломъ, притомъ еще находилось вт, пејіодь линянія.

\section{-_ Tetrao urogallus Linu. Глухарь.}

А. А. Аргуновъ и П. А. II а с тов ск і й сообцили мнь, что глухарей въ окр. Капнска ньтъ. По словамъ церваго они водятся лишь сьвернъе въ урманахъ. Относительно Кулундинской степи у меня ньть фактовт, доказывающихъ присутствіе тамъ глухаря. Относительно Кулундинскаго бора мнбнія м'стныхъ охотниковъ дазке прямо иротиворьчатъ другъ другу. По слухамъ водится въ Касмолинскомъ бору. Въ окр. стан. Семиярской по мнбнію мъстныхъ жителей не встрьчается. По М. Д. Рузскому (стр. 19) глухари водятся въ Курганскихъ борахъ, по А. М орозову

*) См. "Ornitholog. Jahrb." за 1898 г. (иредварительное описаніе) и $3 а 1902$ г. стр. 178-184 (подробное описаніе, геогр. распространеніе и таблица с'ь шзображеніем'ь характернаго признака.). 
(стр. 7) въ Акмолинской обл. глухаря нътъ, онъ встрьчается только въ хвойныхъ лъсах' Тобольской губ.

\section{- Bonasa sylvestris canescens Sparrm. Рлбчик'b.}

Намт, нигдж въ степяхт нашего края не попәдался. По $\mathrm{A}$. Мор о з о в . (стр. 7) встрбчается вмьсть съ глухаремъ въ Тобольской и Томской губ. П. А. Шастовскій сообщилє мнь, что въ окр. Каинска рябчиковъ нъ'гъ.

\section{? Caccabis saxatilis chuka Gray. Kayenua ryponatкa.}

Мъстн. назв.: „каменный рябчикъ“ (ст. Семиярская).

По разсказамъ мъстныхъ охотниковъ встрбчается рбдко подъ стан. Семиярской на Иртышь.

\section{S5. Perdix perdix Linn. Kyponatra ctpag.}

Мъстн. назв.: „рябокъ-гуменникъ“ (г. Каинскъ), „рябчикъ“ (дер. Чистоозерская и стан. Семиярская), „рябокъ“ (с. Ключевое).

Въ Каинскомъ уъздь обыкновенная, осьдлая птица. Найдена близъ г. Каинска (по сообщ. А. Аргу нов а и П. А. Шастовс к аго) и близъ ст. Татарской, гдъ 16/vi 98 у сњрой куропатки были уже выведены цыплята. Подъ Омскомъ по А. М ор озо ву (стр. 7) въ посльдніе годы стала обыкновенной птицей, между тьмъ какъ по И. С ловцову (стр. 150) она раньше встрбчалась очень рбдко. Въ Кулундинской степи нами не добыта, но по сообщеніямъ разныхъ лицъ водится около с. Вылкова, д. Чистоозерской, у с. Ключевого и близъ стан. Семиярской. Въ Кокчетавскомъ уг̌здъ И. С л о вцо в ы в не найдена.

\section{Perdix davurica Pall. Kуронатка бородатая.}

$$
(=\text { P. barbata Verr.) }
$$

По сообщенію П. А. Шастовскаго бородатая куропатка добыта имъ въ пяти экземплярахъ въ 15 в. к”ъ югу отъ ст. Каинскъ въ первыхъ числахъ мая 1902 г.

Въ правильности его ппредбленія я не сомнбваюсь, такъ какъ ему хорошо извъстны отличительные признаки этого восточно-сибирскаго вида. 
Въ литературъ никакихъ указаній на нахожденіе этой куропатки въ степяхъ Загадной Сибири не нахожу.

\section{5\%. Coturnix coturnix orientalis Bogd. Ilepeneлt, во- сточный.}

Этотъ перепелъ, представляющій собою населяющую западную и центральную Сибирь, Туркестанъ и восточныя губ. Европейской Россіи форму, отличается отъ европейскаго типичнаго перепела грязно-бълыми щеками вмъсто краснобурыхъ. Онъ широко распространенъ на гнъздовьъ въ степяхъ нашего края. Это обыкновенная гнЊздящаяся птица въ Барабинской степи. Мы находили и слышали перепеловъ на ст. Убинской, на озерђ Убинскомъ, на ст. Татарской, гдъ мы 20-го іюня 99 г. получили два яӥца. въ посльдней стадіи насиживанія. Яйца содержали птенцовъ, вполнъ покрытыхъ пухомъ. Въ этой кладкъ пыло 11 яицъ. На станціи Коченево намъ 2 кп принесли двухъ молодыхъ. Въ окр. ст. Каинскъ П. А. ІІІ а с т о в с к ій убилъ 11-го мая 1903 г. самку съ готовымъ къ сносу, но не окрашеннымъ яйцомъ, которое онъ извлекъ и предоставилъ мнъ. Цвътъ матовой, безъ блеска, шеро. ховатой скорлупы слабо зеленоватый, почти бълый; просвъчиваетъ зеленымъ. Длина яйца 29.5 при ширинъ въ 20,5 мм. ВЂсъ скорлупы 0,55 гр.--Въ Кулундинской степи мы также почти повсемъстно, начиная отъ д. Плотниковой и кончая ст. Семиярской слышали крикъ перепела. На Иртыш‡ въ посл‡дній разъ 20-го іюля. Степная экспедиція проф. К К щенко доставила въ музей экз. изъ дер. Саушки, Очень обыкновенная птица близь с. Тулинскаго на Оби и подъ Барнаульмъ.

Экземп. коллекціи и измъ̌ренія:

1) t ad д. Саушка 2/vi 00 r. 12 а. 104 с. 34,5 t. 25 шн.

2) ғ ad. с. Ключєвое $11 /$ vi $02 \quad 10 \quad 102 \quad 36 \quad 25$ "

3) ᄒ ad. ст. Татарская $19 /$ vл $99 \quad 12,5 \quad 106 \quad 35 \quad 25$ \%

Размьры и вбссъ яицъ, собранныхъ экспедиціею проф. Н. $\Theta$. Кащен ко 1899 г.;
1) $\frac{30,0 \times 23,0 \text { мм. }}{0,69 \text { гр. }}$ и
2) $\frac{30,0 \times 23,0 \text { ми. }}{0,70 \text { гр. }}$ 


\section{ALECTORIDES (Пастушковыя). ? Rallus aquaticus Linn. IIacrymok'}

Вестма приходится сожальть о томъ, что А. Морозов в (стр. 6) не сообщаеть никакихъ подробностей о нахожденіи этой птицы подъ Омскомъ. У П алласа (стр. 153) уже находится указаніе, что этотъ видъ „Sibiriae citerioris frequens avis“, a между тьим у новъйшихъ изсльдователей эта птица даже не упоминаєтся. Въ нашихъ коллекціяхъ экземпляровъ нб̆тъ.

\section{Crex crex Linn. liopoctesь.}

Коростель-дергачъ очень обыкновенная птица нашихъ степей и крик'ь его слышали мы почти повсемъстно во время нашихъ повздокъ. Но такъ какт, во время экскурсій собакъ съ, нами не было, то экземпляровъ не удалось добыть. Даю измьренія нб̆которыхъ экз. моей частной коллекціи:

1) t ad. окр. г. Барнаула 15/vi 98 r. 22 a. 141 с. 54 t. 42 шк.

2) o ad Австрія (Klein-

München) . . . . . $3 / 15 / 1 \times 89 \quad 20 \quad 134 \quad 49 \quad 40 \quad$ n

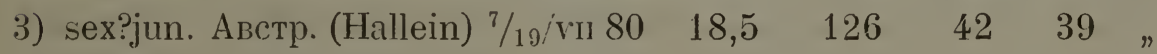

Сио́ирскіе экз., насколько можно судить по небольшому матеріалу для сравненія, нич'Бмъ существеннымъ отъ западно-европейскихъ не отличаютсл.

\section{Ortygometra maruetta Leach. Водяная курочка.}

Водяная курочка найдена нами въ Барабинской и Кулундинской степяхъ. Характерные ввуки этой птицы часто раздавались во второй половинЕ іюня 1899 г. во время нашего пребыванія на ст. Татарской. Въ Кулундинской степи я только разъ, вечеромъ 1-го іюля 1903 г., слышалъ этотъ хорюшо мнб извъстный звукъ въ с. Камышенкъ, Барнаульск. у. Безъ собаки птицъ добыть не удалось. Близъ Бариаула обыкновенна. 
Даю измбренія нбсколькихъ экземп. моей частной коллекціи: 1) ғ ad. окр. г. Барнаула 11/ris 98 r. 20,5 a. 122 с. 50 t. 35 шк. 2) sex?juv.

3) б ad. ст. Каинскъ $19 /$ vII 98

19

116

4932 "

4) a․ Австрія (Rainachthal) $3 / 15 /$ vir 84

$21 \quad 117$

52

34 n

$17 \quad 120 \quad 48 \quad 35 \%$

Изъ литературныхъ данныхъ сльдуетъ, что пестрая водяная курочка широко распространена и въ мъстностяхъ, прилегаюшцхъ къ степной части нашего края.

\section{Ortygometra auricularis Reichenow. Hypoчка-крош- la восточпо-сибирсная.}

А. П. Велиж анин д добыль въ окр. г. Барнаула въ концъ іюля, въ августь и сентябрб 1899 и 1901 гг. нбсколько экземпляровъ курочки-крошки, переданныхъ имъ частью вт зоологическій музей нашего университета, частью проданныхъ мнъ. Такъ какъ это были все молодые экз., то точнаго опредъленія (лодвидового) нельзя было произвести. Счастливая случайность лоставила въ мои руки экъемпляръ въ весеннемъ опереніи, добытый 26/Iv 1903 г. въ 15 верст. отъ Томска на берегу р. Ушайки, несомнбнно принадлежащцій гъ описанной проф). А. Reichenow'ымъ восточной формб. Думая, что и барнаульскіе әкземпляры курочки-крошки окажутся принадлежащими къ новой формъ, за которой признается теперь не только вначеніе полвида, но даже вида, я привожу курочекъ-крошекъ нашего края подъ новымъ видовымъ названіемъ.

С. А. Бутурли ну приношу искреннюю благодарность за предоставленный мнб на нбкоторое вреня весенній экземпляр курочки-крошки (O. pusilla Pall.=-bailloni Vieill.) изъ южной Франціи, оказавшій мнб несомнбнныя услуги при опредъленіи и окончательно разсъявшій сомнънія въ правильности его.

Измьренія:

1) O. pusilia Nice t ad. ${ }^{29} / ш 11 /$ Ir 00 r. 16,5 a. $89-90$ c. 49 t. 29 шк.

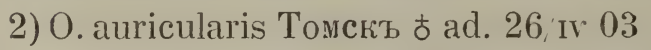
$17 \quad 90-91 \quad 43 \quad 29$ ” 3)

4) n Барнауль б juv. 24/vir 99 15 5) O. „bailloni“ " sex?juv. 29/vil 01 15 89 4828,5 " » $\quad$ juv. $3 /$ vin 99 15 91 4728 ” 8640 ?24 чуч. 


\section{Ortygometra pusilla Pall. Kypoчka-kpomka занад- ная.}

F ins ch (стр. 255) утвержідаетъ, что видђ.љ экз. изъ окр. Омска въ коллекціи Словцов а, по которому (стр. 158) она найдена около половины мая. А. М ор озов т (стр. 6) сообщаетъ, что малая водяная курочка встрбчается „по всъмъ маловоднымъ озерамъ, въ камышахъ“. Къ какой форм' относятся эти показанія, выяснятъ будущія изслъдованія. Весьма возможно, что объ формы встрбчаются въ нашихъ степяхъ.

\section{- Gallinula chloropus Linn. lianыница.}

На нахожденіе камышницы въ Западной Сибири указываютъ слова Палл а са (стр. 157) „Sibiriae citerioris.... satis frequens“. Пก С. А. Бутурлину (стр 75) „въ Западной Сибири не доходитъ до Тобольской губ́.“. О. нахожденіи ея въ Томскомъ краъ ничего неизвъстно.

\section{Fulica atra Linn. Jucyxa.}

Мъстн. назв.: „лысая гагара“ (дер. Плотникова, Чистоозерская, с. Ключевое).

Лысуха въ качествђ гнбздящейся птицы найдена въ Барабинской и Кулундинской степяхъ. Мъстонахожденія ея: с. Карганъ, оз. близъ ст. Каинскъ, оз. Убинское и др., озера близъ дер. Плотниковой, Чистоозерской, с. Ключевого. По И. Я. С л о вц о в у (стр. 230) лысуха сравнительно часто встрьчается въ средней и южной части Тобольской губ. М. Д. Р уз скій (стр. 24) находиль ее на прысныхъ и солоноватыхь озерахъ южной полосы Тобольской губ. О. F in $\mathrm{sch}$ (стр. 255) находилъ лысуху близъ деревни БЪллоглазовой (Колыванскій заводъ) и видълъ экз. изъ окр. Омска въ коллекціи Словцова. Под'ь Омскомъ по И. Я. С л о в ц о в у (стр. 158) и по А. М о р озов у (стр. 6) лысүха „весьма распространенный видъ по всђмъ озерамъ“.

На Иртышь въ окрестностяхъ пос. Ямышевскаго лысухъ по В. Н. П ло т н и ков у (стр. 18) „довольно много“. Экспедиція П. Г. Игнатов а (стр. 16 В. Бі анки) въ Акмолинскомъ и Атбасарскомъ убздахъ собрала значительный матеріалъ. 
Экземпляры коллекцій:

1) jur. sex?. с. Карганъ 30 ri 91 r. 25 а. 165 с. 56 t. 63 шк.

$\begin{array}{llllllll}\text { 2) ᄒ ad. д. Чистоозерская } & 24 / \text { vi } & 02 & 28 & 211 & 54 & 56 \text { ” } \\ \text { 3) pull. sex? } & 21 / \text { vi } & 02 & 20 & - & - & 57\end{array}$

Длина клюва измфрялась отъ передняго края оперенія по бокамт „б.ляхи“.

Размњры и вђст, скорлупы одного яйца, взятаго во второй половинь мая 1907 г. близъ ст. Каинскъ и любезно предоставленнаго мнь П. А. Ш аст о в ски м ь $=\frac{54,2 \times 38,0 \text { мм. }}{3,47 \text { гр. } . ~ Я и ̆ ц о ~}$ вполн'ь походить на рис. 26 табл. 19. „Naumann“a.

\section{Grus grus lilfordi Sharpe. भууравль cyрый восточ- шыі.}

Въ Каинскомт убздъ сђрый журавль весьма обыкновенная, гнъздящаяся птица. Найденъ въ, окр. ст. Уоринской, Татарской, Каннска и Коченева. Отъ П. А. НІастовскаго я получиль дв方 кладки сбраго журавля изъ окрестностей ст. Кэинскъ. Первая, переданная мною въ зоологическій музей нашего университета, состояла изъ одного только насиженнаго яйца въ гнбъдъ, найденномъ 11-го мая 1903 г. Вторая кладка изъ двухъ ненасиженныхъ яицъ, взята 16-го мая 1903 г.

Размьры и въсъ яицъ въ мм. и гр.

$$
\text { 1) } \frac{96,0 \times(11,0}{18,87} \text {; 2) } \frac{93,0 \times 61.0}{20,0} \text { и 3) } \frac{96,0 \times 63,0}{19,3} \text {. }
$$

Въ Кулундинской степи сьрый журавль водится также въ значительномь количествъ. Мы находили его въ степи около дер. Плотниковой, въ Кулунцинскомъ бору у с. Вылкова, около озера Рыбальнаго; по сообщенію мъстныхъ охотниковъ массами встрьqается осенью на пролеть въ окр. дер. Чистоозерской; несомнынно гн'ъ?дится близъ устья р. Кулунды. Хотя въ нашемъ музеъ экземпляровъ изт степной части Томскаго края нб̆тъ, но думаю не ошибиться, причисляя сњрыхъ журавлей степныхъ мбстностей къ восточному подвиду, самостоятельность котораго пока еще впротемь очень сомнительна. С'ьрые журавли нашего музея изъ окр. Томсга во всяком случаб имбютъ свт̌тлые, пелельно-сърые, 
а не темные третьестепенные махи. Вт приалтайскихъ степяхъ встрьчается.

По И. Я. С ло в цо в у (стр. 229) сърый журавль „самая обыкновенная птица во встхъ округахъ Тобольской губ, въ юзной полосъ которой найденъ и М. Д. Р узски м ъ (стр. 12) въ солончаковой степи. Подт, Омскомъ по И. Я. С ло вцову (стр. 153) и А. Морозову (стр. 4) „обычная птица, гн'ъздится". На Иртыш' въ окрестн. пос. Ямышевскаго по В. Н. Пло тн и ков у (стр. 18) об̆ыкновенное явленіе.

\section{Grus monachus Temm. अуравль-монах'b.}

Ст. тьхх поръ какъ В. П. А н и ки н удалось пріобрбсти въ, окр. с. Сиасскаго близт Томска (вт, 1893 г.) экземпляръ журавлямонаха, свъдънія наши о распространеніи этого журавля въ предъ̆лахъ Томскаго края не особ́енно обогатились. Въ 1896 г. въь мағ на томсконъ базарғ $九$ А. Куртуковымъ было куплено у одного крестьянина свъжее яйцо журавля, которое, побнвавъ въ рукахт разныхт, спеціалистовъ, иежду прочимъ Г. Ф. Гебеля, считается яйцоиъ этого журавля. Въ письмы на имя Совъта Зап. Сиб. Общества Сельскаго.Хозяйства отъ 4/ı 1899 г. А. И. К рах ал е в в высказываетъ уббжденіе „что журавль-монахъ если не каждое льто, то все же гньздится на обширныхъ Чанскихъ островахъ, в'ь сторонъ отъ крестьянскихъ селеній въдомства Юдинской волости, Каинскаго ућзда“. Во время нашихъ поъздокъ по степямъ нашего края этоть журавль намъ не попадался. По сообщенію охотника Е. П. Горбунов а разъ убитъ близъ с. Коченева.

\section{Grus lencogeranus Pall. С'ерхь, журав.и болый.}

Одаимъ изъ интереснбйших'ь журавлей степной тасти нашего края является бълый журавль или стерхъ, какъ птица, о которой литературныхъ свъдъній имъется сравнительно много, между тъмъ какъ въ коллекціяхъ матеріаль по этому виду отсутствуетъ. Уже со временъ П аллас а (стр. 104) извъстно, что стерхъ водится въ Барабинской степи и въ Нарымскомъ краъ. Брэменская экспедиція (F i s c h, стр. 247) нашла этого журавля въ Барнауль, гдъ ей удалось отъ охотника купить 10/vi 1876 убитый наканунь экзеипляръ. По И. Я. Сл ов цо в у (стр. 
229) стерхъ уобитъ близъ Тюмени 7-го іюня 1886 г. „Три года подъ рядъ видћли пару стерховъ, которые, какъ полагаютъ охотники, здъсь и гнбздились. С'ъ 1886-го года бълыхъ журавлей въ Тюменскомъ округь не встрбчали“. У М. Д. Рузска го (стр. $3,12,20$, 25 и 29) мы находимъ, что онъ самъ наблюдалъ на озеръ Таволжанъ „пару этихъ огромныхъ птицъ“. Добыть экз. не удалось. У А. М о р о зо в а (стр. 4) есть указаніе, что стерхъ подъ Омскомъ „по разсказамъ, изрьдка встрььчается“. И. С ловц о в ъ (стр. 153) видълъ въ Кокчетавскомъ уғздъ пару бълыхъ журавлей. Во время нашихъ поъздокъ стерхъ пи разу не наблюдался. Въ окрестностяхъ ст. Убинской (Барабинская степь) стерхъ по сообщенію мъстныхъ жіителей нысколько разъ встрьчался, но никому не удавалось его убить. А. А. Аргунов ъ сообщиль мнъ, что этотъ журавль встрьччется въ оюр. ст. Каинскъ. На ст. Татарской его уб́или за нъсколько дней до нашего прібзда туда въ 1899 г. и.... съъьли! По сообщенію П. А. ШІасто в скаго онт 17-го мая 1904 г. неудачно стрбляль по стерху вт, 6 верстахъ отъ Каинска.

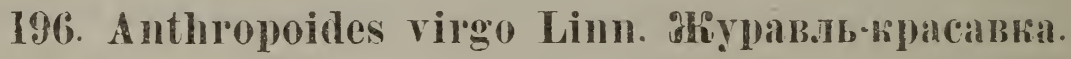

Мъстн. назв.: „журавль чубатый“ (ст. Каинскљ).

Журавль-красавка не тольно гнъздяща яся птица Алтая, гдъ

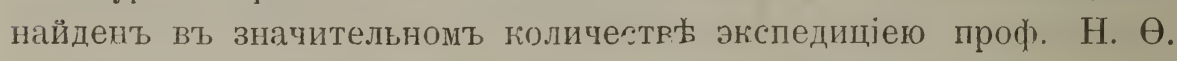

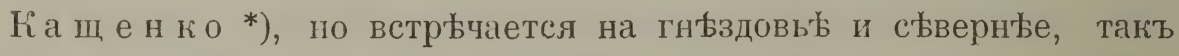
какъ найденъ въ окр. Барнаула А. ПЈ. В е ли ж а н и н ы м ъ (む и 우 ㄷ и v 1897 г.), въ окр. с. Дубровина на Оби моимъ бывшимъ ученикомь 3. Яце в ичем л ль̆томъ 1897 г. и, наконецъ, около ст. Каинскъ II. А. Ш а с т о в с к и м ъ 11 -го мая 1903 г. У дер. Будашки близъ названной станщіи онъ видъ.љ этихъ журавлей и спугнулъ одного изъ нихъ съ гнбзда. Въ гнъздъ было два яйца, любезно предоставленныхъ имъ мнъ. Разибры яицъ $94,0 \times$ 59,0 и $92,0 \times 59$ мм., въсъ ихъ 17,85 и 16,76 гр. Разспросы наши мъстныхъ охотниковъ на разныхъ станціяхъ въ Барабъ не дали полозительныхъ результатовъ.

Въ Кулундинской степи этоть журавль намъ не попадался, но весьма возможно, чти он'к и зпћьсь спорадически гнбздится,

*) см. „Резунтағы" стр. 94. 
такъ какъ по союбщенію м'љсныхъ жителсй встрьчается въ окрестностяхт дер. Чистоозерской.

Экземплярь коллекціи:

1) sех? г. Барнауль. Iv 1897 г. г. 67 а. 470 с. 175 t. 172 (чучело унив. колл.)

У одного только В. Н. П лотников а (стр. 18) помғниена замбтка о томъ, что „этотъ экуравль, извŁстный у казаковъ подъ именемь стерха, попадается въ незначительномъ количестьь по берегамъ затоновъ и въ степи“ близь пос. Ямышевскаго на Иртышь. Другихъ указаній въ литературь нашихъ степей нытъ.

\section{9\%. Otis tarda Linn. Ipot)a.}

Мъстн. лазв.: „польская курица“ (оз. Маралда, Шавлодарск. у , стан. Семиярская; „дуадах“ (киргизск. назв., стан. Семиярская).

Въ Барабинской и Кулундинской степяхъ дрофы намъ не попадались и экземпляровъ въ нашихъ коллекціяхь нътъ. По сообценію А. А. А р гунова дрофа нексколько разт наблюдалась вь качествъ случайно залетной въ окрестностяхь г. Гаинска. Иногда она привозится на базарь въ Каинскь и часто встрь. чается около озера Чаны. Что касается Кулундинской степи, то по разсказамь мьстныхт охотниковъ дрофа рьдко встрьчается около дер. Чистоозерской, около оз. Маралда, но не особенно часто въ окр. Семиярской, гдґ предпочитаетъ львый берегъ Иртыша. Годами онь во множествь появляются и на правомъ берегъ. Въ приалтайскихт, степяхъ (с. Покоть и др.) иногда появляютея по разсказамъ жкителей.

Finsch (стр. 241) наблюдалт дрофъ въ степяхъ нашего края, но точнаго мћстонахожденія не упоминаеть. По М. Д. Р уз скому (стр. 30 и 11) дрофы гньздятся въ прииртышскихъ и приишимскихъ степяхъ. IIо А. М о розо в у (стр. 6) дрофа встрбчается во всей Акмолинской области; въ окрестн. Омска (не ближе $60-80$ верстъ) появляется изрьдка. Для Омскаго у. приводится и В. С. Елца тье в ским п. По В. Н. Плотникову (стр. 13) дрофа въ окр. пос. Ямышевскаго, повидимому, гньздящаяся птица. П. Г. Иг н а то в ъ (см. Б і анки стр. 16) добылъ нбсколько взрослыхъ и молодыхъ экземпляровъ въ Акмолинскомъ и Атб́асарскомъ у. И. Я. С лов ц в ъ полагаетъ, что кромь большой дрофы въ Кокчетавскомъ у. можетъ встрьчаться 
и дрофа-виляй (Otis macqueenii Gray), но пока это еще не доказано (1897 стр. 151).

\section{S. Otis tetrax Linn. C'pener't.}

Мъстн. назв. „пердунокъ “ (дер. Нижній Кучукъ); киргизское назв. „безгылдык" (стан. Семиярская).

По сообщенію А. А. Аргунова стрепеть разъ гнғздился въ окрестностяхъ г. Каинска, гдь его видьль и П.А. Ш а с т о вскій. Намъ удалось узнать, что онъ осенью появляется въ окр. станц. Татарской. Случайно появляется онъ и на значительномъ разстояніи оть мъстъ гнћздовья, о чемъ свидътельствуетъ чучело, хранящееся въ нашемъ музеъ. Экземпляръ этотъ добытъ въ окрестностяхъ Томска 30-го іюня $1890 \mathrm{r}$.

Въ Кулундинской степи по сообщенію мъстных'ь жителей стрепеть встрьчается близъ дер. Чистоозерской чаще дрофы. Почти ежегодно убивается по р. Степному Кучуку и близъ стан. Семиярской. Къ приалтайскихъ степяхъ слрепетъ водится. Въ окрестностяхъ с. Убинскаго на Уб̆ 27 ri 00 дважды стрбляли по стрепету, но безуспьшн. Стрепеть найденъ М. Р уз ск и м (стр. 11 и 12) въ южной степной полосъ Тобольской губ. По А. Морозову (стр. 7) это „обычная форма подъ Онскомь и во всей степи". По И. Я. С ло в цо в у (стр. 151) стрепелъ въ Кокчетавскомъ уюзды не составляетъ рьдкости. В. Н. Плотник о в ъ (стр. 13) сообщаетъ, что „стрепетъ попадается пь степи гораздо рьже дрофы“. По В. С. Ел п а тьев скому (стр. 141) стрепетъ гнбздуетъ въ Омскомъ у. не южнье границы островныхъ львсовъ. 


\section{HEROIDIONES (Цапленыя).

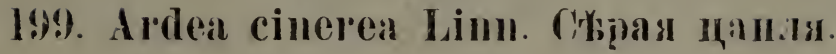

Сђрая цапля по сообщенію мъстныхъ жителей встрычается вь Барабинской степи. О ней намъ говорили въ с. Коченевъ и па сг. Татарской. Благодаря любезности г-на П. О. Ш у ль ъ. замьтившаго отсутствіе этого вида въ нашей коллекціи, зоологическій музей обогатился чучеломъ взрослой цапли. пожертвованнымъ имъ. Экземпляръ убитъ въ окр. г. Омска 15-го апрьля 1902 г. въ 6 верстахт. отъ города; птица стояла въ водь боло та глубиною около 6 дюймовт. Привожу здьсь измьренія этого экземпляра:

t ad. 1. 130 ad. около 480, as. около 490. с. 190 t. 167.

Въ Кулундинской степи я только разъ, 28-го іюня 1902 г. видъ̆ль цаплю вт окрестн, дер. Чистоозерской, стоявшую неподвижно на берегу озера Грачиха. При нашемъ приближеніи она улетьльа.

По собщеню А. П. В ел и жан н н а въ іюль 1899 г. сьрая цапля убита близъ Барнаула.

F insch (стр). 248) видъ̆ль въ, коллекціи И. Словцов а (см. 1879 стр. 153) экз. изт окр. г. Омска. По С ло в цо в у (стр. 235) „сьрая цапля обитаеть вт, разныхъ мћстахъ съверной части Тобольской губерніи, но всегда изрьдка, отдъльными парами, и притомъ не ежегодно въ одномъ и томъ же мьсть“. М. Р узс ки м (стр. 25) сьрая цапля найдена и въ южной части Тобольской губерніи, По А. Морозову (стр. 4) она подъ Омскомъ „весной и осенью весьма обыкновенна; гнъздуетъ сьвернъе“. На Иртышб близъ пос. Ямышевскаго сьрая цапля „была зам'ъена всего одинь разъ въ 1894 году осенью", „да одинъ раз`ь В. Н. П лот н и ко в ъ (стр. 17) нашель скелеть ея близъ оз. Соляного ". Экспедиція П. Г. Игн а това добыла богатую коллекшію этого вида в'є Акмолинскомъ и Ато́асарскомъ у ъздахъ (см. Бі анки итр. 20). Въ Кокчетавскомъ убздъ И. Я. Слов. ц о в ы м ъ (стр. 153) нигдь не найдена. 


\section{Herodias alba Linn. Большая б's.ла ченура.}

По проф, М. А. Мензо́иру (Птицы Россіи стр. 804) эта цапля гнбздится въ гого-западной Сибири къ съверу до $47^{\circ}$ с. ш. В. Н. Пло т и и к о в ъ (стр. 17) сообщаетъ, что она только разъ была замъчена близъ пос. Ямышевскаго, гдъ провела два дня, а затьмт отлетьла далье. Бълая цапля приводится В. Бі інки (стр. 20) для Атбасарскаго у. на основаніи сборовъ экспедиціи П. Г. Иг н а т о в а. Въ нашихъ стєпях ь пока не найдена*).

\section{- Ardetta minuta Limn. Волчокт.}

(Botaurus minutus Linn.)

О нахожденіи волчка в'ъ степяхъ Томскаго края пока ничего неизвъстно. И. Я. С л о в ц о в ъ (стр. 234) нашель его только въ Курганскомь округь и близъ Шадринска. По М. Р у з с ко м у (стр. 23) волчокъ населяетъ камышевыя и тростниковыя заросли озеръ въ южной части Тобольской губ. Точное мъстонахожденіе имъ не указывается.

\section{Botaurus stellaris Linn. Bunb.}

М官тн. назв.: „выпъ“ (оз. Убинское), „шубинъ“ (дер Плотникова). „фыпъ“ (дер. Чистопзерская и стан. Семиярская), „филинъ“ (дер. Чистоозерская).

Въ Барабинской степи выпь мЂстами очень обыкновенна. На озерь Убинскомъ близю заимки П. Ка ба н о ва глухіе звуки ея „мычанія" безпрестанно раздавались и доносились отовсюду изъ камышей не только въ ночь съ 9-го на 10-ое іюня 1899 г., которую я здъсь провель, ни и утромъ и даже въ полдень 10-го іюня.-Гнъзда выпи съ ея красивыми яйцами П. А. Ш а с то вс ж і й находилъ на оз. Шубинъ близъ ст. Каинскъ. На озерахъ Кулундинской степи, заросшихъ камышами и тростниками, выпь также очень нерьдка. Крики самцовъ я слышалъ на большихъ озерахъ около дер. Плотниковой 14-го іюня 1902 г., но крикъ этотъ раздавался не такъ часто, какъ въ Барабъ. Выпь часто встрьчается на озерахъ близъ дер. Чистоозерской, гдъв я за одну охоту видълъ не менъе 7 особей, изъ которыхъ одну убилъ.

*) Въ концј октября 1907 г. заблудившійся экз. убит'ь въ окр. Тохска. 
Встрђчается вынь и въ конечномъ пункть нашей пюбздки 1902 г. В'є, окрестностяхъ стан. Семиярской.

Экземпляръ коллекціи;

1) + ad д. Чисгоозерская $28 /$ v 02 r. 70,5 а. 308 c. 105 t. 97 шк.

Для Тобольской губ. выпь приводится И. Я. С ло в ц о в м ъ (стр. 284) и М. Д. Рузски и (стр. 23). По А. Морозову (стр. 4) и И. С лов в о в у (стр. 154) выпь подъ Омскомъ встръчается „очень часто, гнђздится". На Иртышђ въ окрестн. пос. Ямышевскаго выпь многочисленна (В. Н. ІІлотниковъ стр. 17). Въ Когчетавскомъ убзды голосъ выпи сльшаль И. Сливцов ъ (стр. 154).

\section{- Nycticorax nycticorax Limu. Kваква.}

Въ Атбасарскомъ у. экспедиція П. Г. Игнат о ва добыла t juv. (см. В. Біанки стр. 20). Въ степяхъ нашего края пока не найдена.

\section{0\%. Ciconia nigra Linn. Черный ancть.}

Черный аисть въ степяхъ нашего края намъ не попадался. Приводится А. М и дд е ндорфом'ь (Isipiptesen стр. 68) для Барнаула. O. Fin sc $\jmath_{1}$ видьль въ коллекціи И. Словцова (см. 1897 стр. 154) экз. изъ окрестностей Омска (стр. 248). въроятно, случайно залетный. И. Я. С л ов и в т. (стр. 234) приводитъ черныхъ аистовъ для Тюмени въ качествђ пролетныхъ. В. Н. П ло тников ъ (стр. 18) разъ встрбтилъ чернаго аиста близъ пос. Ямычевскаго. Въ Кокчетавскомъ убздъ и близъ Омска И. Я. С ло в ц о в ы м не найденъ (стр. 154).

\section{? Platalea lencorodia Linu. Kodmuцa.}

Колпица по П алласу (стр. 162) встрбчается въ Барабинской степи. О нахожденіи ея тамъ въ настоящее время ничего неизвъстно. Для Акмолинскаго у. она приводится В. Л. Біанки (стр. 20) на основаніи ф аd., добытой экспедиціею П. Г. Игнатова. 


\title{
IX. LIMICOLAE. (Кулики).
}

\section{Oedicnemus oedichemus Linn Abrotia.}

\author{
(= Oed crepitans Temm.)
}

Съверпая граница распространепія авдотки въ степяхъ За. падной Сибири еще далеко не выяснена. Между тьми какт С. А. Бу турли н в считаеть $48^{\circ}$ аа свверную границу, у А. Моров о в а (стр. 6) сообцается. что авдотка (подь Омскомт?) „встрђчается, но ие часто, преииущественно за Иртышомь вт, степи “. Во время нашихъ, пољздокт, по степямт, Томскаго прая авдотка не была добыта, в'роятно, всльдствіе ея ночного образа жизни и умжнія скрываться при приближеніи человђка. Но вт Барабинской степи авдотка добыта II. А III а с тов с к и м ъ, доставившемт, мн в экз. изъ окрестнстей ст. Каинсіъ, гды ему нъскилько разъ весною 1904 г. пришлось видтыт эту птиц. Доставлениый ми' әкземплярь въ изнопениомь ппереніи и убить въ 35 в. отъ станци и

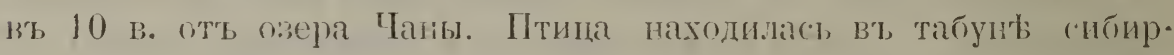
скихъ ржанокъ.

Измжрепія:

1) む ad. ст. Канискъ $20 /$ w 04 r. 37 a. 240 c. 114 t. 82 чуч.

На третьемъ изъ первостепеныхъ маховыхъ нбтъ бълыхъ отмбтинъ. Экземпляъ пріобрбтенъ Зоологическимъ музеемъ.

\section{Glapeola nelanoptera Norim. 'Puprymlä cremag.}

M⿻аян. назв.: „красноустик' " (стан. Семиярская, сравн. и В. Н. ІІло ти и піов в стр. 13).

Большою неожиданностьо для меня было убовдитсья в' присутствіи степной тиркушии въ качеств' гнб̈здящейся птнцы въ весточныхъ частяхъ Кул!ндинской стеши. Свђдыній о нахожденіи тиргушегт в', Томской губ. вообще не имбется пі) литературнымъ даннымъ, а энспедиціи, ранъе работавшія въ разныхт, мы. стахъ, нашего края, не циставил ни одного экземпляа въ нашъ музей. 14-го іюня 1902 г. мною была предпринята әкскурсія къ 
тремг, паходящимся па ㅇ, отт деревни Плотниковой (верамт

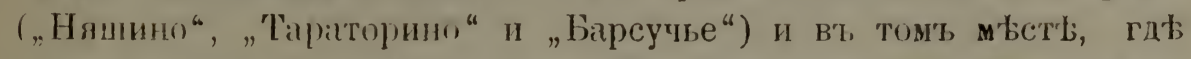

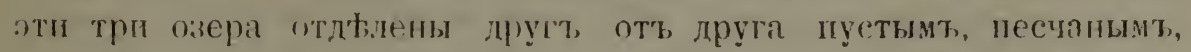

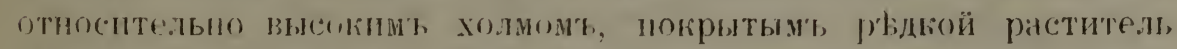

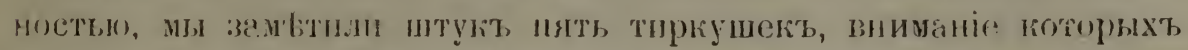
вт, свою очередь был возбуждено нашимъ появленіемь въ этомь глухомь уголк'. Моему спутнику И. Н. К и р илл ов у поечастливилось доб̆ыть, из', этой станіки два экземиляра. Період' вындки яицъ у тпикушект зд'ьсь, повидимому, уже окончился, такъ какъ яцчникъ добытой самки был, уже редуцированъ, при болышм насьдномь пятнт. Далье на занадт, эти тиркушки попадались намъ близъ дер. Нижній-Кучукъ, „на устьяхъ рр. Степного Кучука и Кулунды, въ стеняхт, Павлодарскаго у⿺ззда и близъ стан. (емиярской на Иртышы.

Пзмлренія апземпляровъ коллекціи:

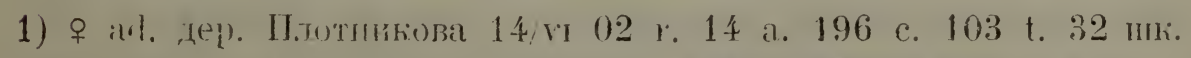

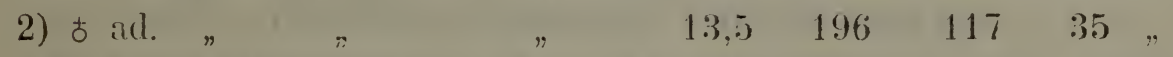

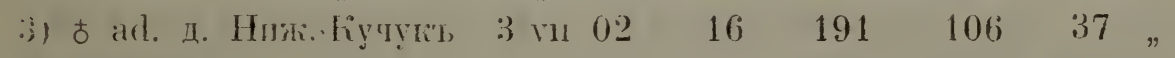
4 ) $\begin{array}{lllllll} & \text { arl. } & 15 & 196 & 110 & 37\end{array}$ 5) 9 arl. " " $" 15019501015 \%$ (i d ad пер. Illeмонина 5, vir $02 \quad 15,5 \quad 194 \quad 104 \quad 37$ ” 7) sex?. ad. " $\quad 14 \quad 197 \quad 105 \quad 37$ xym.

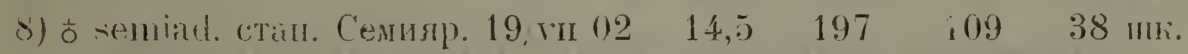
$9)$ sex? jux. " $\quad 11 \quad 165 \quad 71 \quad 35$,

Для срарненія привожу измъренія шкурки этого вида пзъ

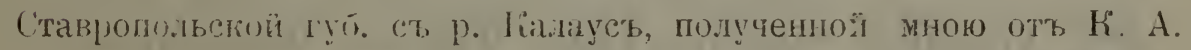
Сатунила, и әкземпляра степной тиркушки, присланной мнъ $V$. von Tschus пзъ его погатой колшекціи, добытый близъ Саренты.

1) t ad. I r 99 p. Kastaycb 1. 14 a. 198 c. 97 t. 37

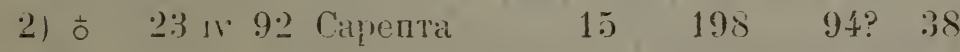

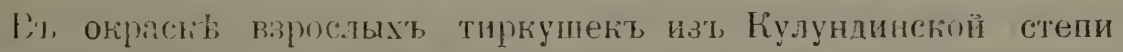
въ сравненіи сь экз. пзт, Ставропольской губ. и изъ Сарешты можн) замбтить ныкоторун разницу. Г'орло и зоб́'ь, окруженные черной полосой, у кучундинскихъ экз. чрезвычайно ольдны, почти

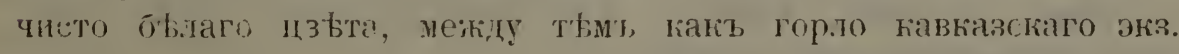
охристое. Горло сарептскаго әкз. темнте горда сиоирскихъ, но 


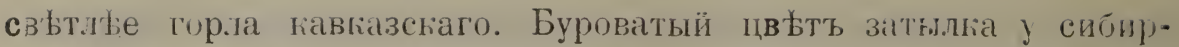
слихъ экземпляровъ бльдные, чьмъ у кавказскаго и сарептскаго. Черная полоса, окружаюшая зобъ и горло, канется мит у сибирслпхъ экз. болье узкою и бльдною. Хотя матеріала д.я сравненія въ моенъ распоряженіи пенного, но думаг, что указаншыя отличія подтвердятся и при сравненіи большаго числа взрослыхь әкземпляровъ западнаго и восточнаго происхожденія. Выдыляю болье бльдныя сибирскія особи ВТ особыи подвидъ, который предысаго наввать Gl. melanoptera pallidogularis subsp. 11 к. По сообщенію П. А. Ш а стовскаго степная тиркушка встрьуается въ окр. ст. Каннсљъ, но нами въ Барабинской степи не наблюдалась. Относительно распространенія этой тирғушии хитересны слова Јалласа (стр. 150): , in omni deserto Tatarico a Volga urque fere ad Intin.... frequentissima; ultua Irtin et reliqua Siliria nusquam apparuit". Вz настоянее время степная тиркушка доходитъ на востокь до Оби. Возможнн, что область тнцздовья этой птици постепенно расширяетея на востокъ. Найдеиа $И$. Я.

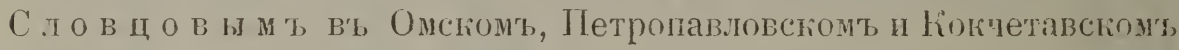

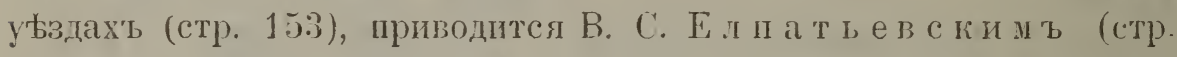
141) для Оискаго увзда. У А. M о розова (стр. (6) находимь о тиркушкахь линь , nomiнa nuda“. 11 В. Н. П ло т ников у (стр. 1:3) въ окр. пос. Ямышевскаго тиркушка встүјчается, хотя и въ незначительномъ количеству.

\section{? Glareola pratincola Linn. 'Tuphymba ayrobas.}

У А. М оризова (стр. 6) nomen nudum!.

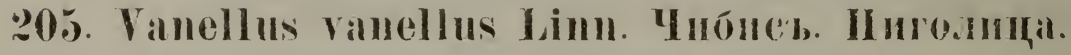

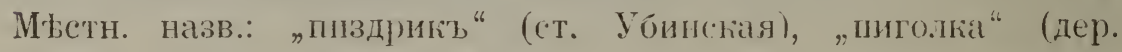
Казакова бливъ ст. Коченевой).

Со мньніемъ II а.л ла са (стр. 132) „in Sibiria raro apparet, attamen circa Obum et Angaram et ad lacus Danuriae passim observatur" в' настоящее время врядъ-ли можно согласнться. Вь Западной Сибири чибись в' предьлахт разсматриваемаго района въ настоящеє время всюду очень обыкновенная, встрбчающаяся въ большомъ числь особей, гнъздящаяся птица. Мы находили его псчти на всьхъ мьстахъ, гдњ коллектировали болье или менъе продолжительное время. 
Экземиляры кодикицін:

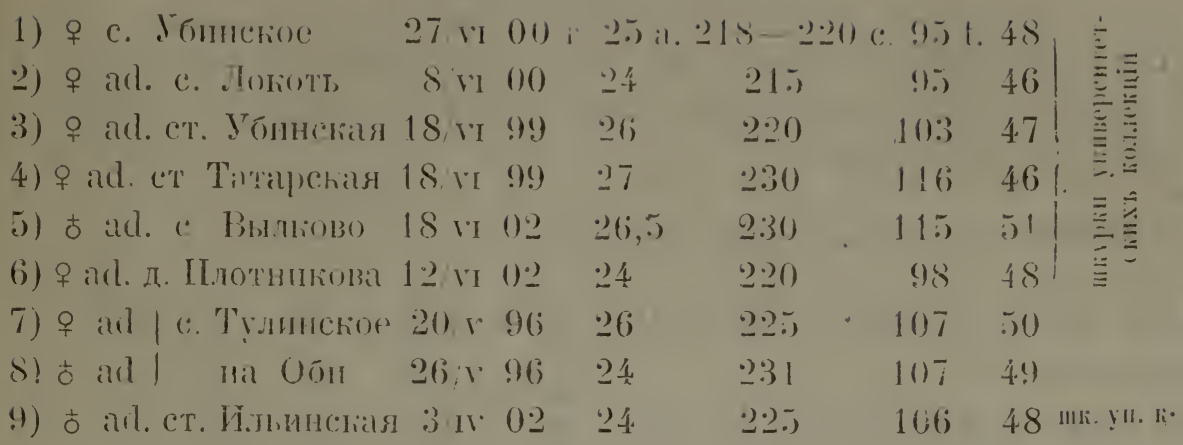

('ъ литературными данным! натии наблюденія стносительно

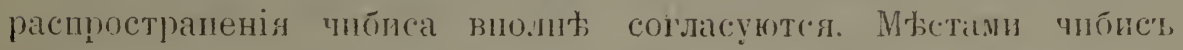

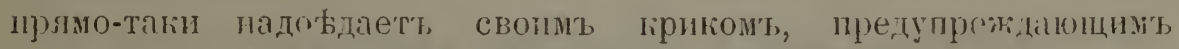
другихъ пернатыхъ о приб.лизіеніи человыка.

\section{Vamellus gregarius Pall. Vipevertia.}

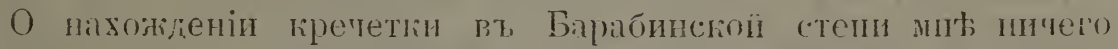

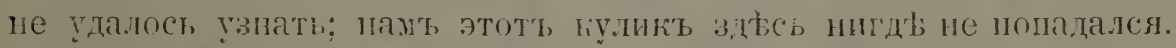

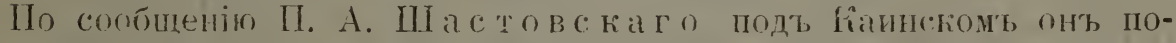

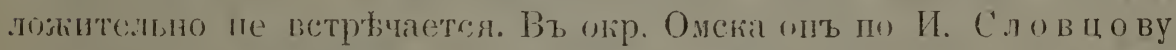
(стр. 152) и А. Морозову (етр 6) огыніовенент, но встры-

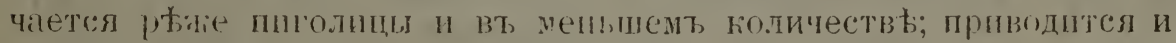
В. С. Елпатғевеким (стр. 141) д.я Олстато увзда. Во время

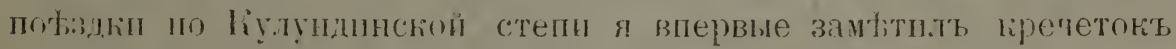
близт, дер. Нижній-К!ч!юь, но намт, потему-то не посчаст.ивилось ухъ здЫсь доп̆ыть. Оны здысь держались близт деревни маленькими стаями, штукъ по пяти. 21-го іюля 1902 г. л во время әкскурсіи по правому берегу Иртыша близъ ст. Семиярской увицЂлъ стаю пречетогъ, неспихся чрезъ Иртышъ изъ стени на львомъ берегу прямо на меня. Свернувъ затьит къ возвыпенному берегу и пивернув' па югь, вея эта крисивая стая расположилась на ровной степи передо мною. Вскорь изт за Иртыша показалась вторая стая, пропзвела тотэ, же маневръ, соединилась, съ первой стаей, и получнлась грасивая картина: табунъ штукъ въ $300-$ 350 кречетокъ передо мною!... Здысь я поняль какъ мытко характеризуетъ, данное ГІ алласои'ь видовое названіе gregarius повадки этихъ птицт. Движенія этой стаи пронсходи.ти ва разъ, 
каки по чьей-то командь. Одновременно, вь одй моменть, вся стая садидась, на землю, вт. другой, опять-тани всь заразь, сни-

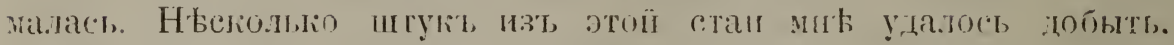

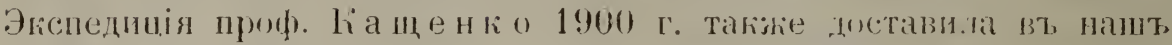
музей лва әкземиляра

Изитренія эквемпняровъ польекцін:

1) 우 ad. с. Убинское 28 v 00 r. 28 a. 195 c. 76 t. 53 пик

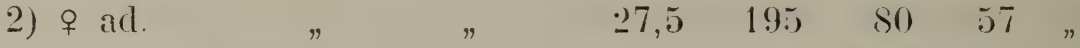

3) 우 ad. cт. Семнярская 21 मи $02 \quad 30 \quad 193 \quad 87 \quad 60$ "

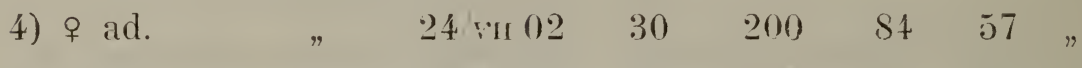

j) tod. \# 24 in $02 \quad 30 \quad 210 \quad 9160 \quad$

\section{0\%. Charadrius squatarola Limn Tyecto.}

\section{( = Ch. hypomelanus Pall. = Ch. helveticus Briss.)}

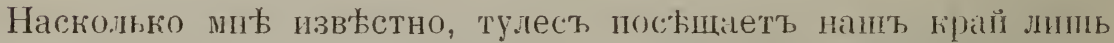
на пролетж, который около Томска происходить вһ первоці трети сентября. Такъ какъ весною и осенью не ћмллектировали въ степяхь 'Тмскаго ғрая, неудизительно, что въ музеђ матеріала нђть. Даю измьренія одного убитаго подт Томсконт экземпльра (въ моей частной коллекціи): б. јuу $4 / \mathrm{Ix} 96 \mathrm{r.} 29$ а. 197 с. 80 t. 49. И. С лов цов в (стр. 152) считаєть его для Омска лишь пролетнымъ, но по А. Морозов у кромь того (стр. 6) „встрђчалтея льтомъ какт одиночныя формы, по 2-3 птуки, рыдко больше“. В. Н. Плот и п ковым н не упоминается для Иртыша, что весьма странно.

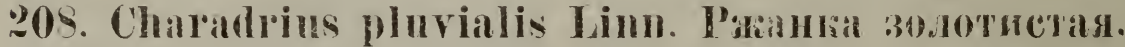

$$
\text { (= Ch. amatus Bechst.) }
$$

По литературнымь указаніямъ посьцаетъ наши степи пролетомъ (И. Слов вов т). По Палласу (етр. 140 и 141) найдена въ Барабж. IІо Морозов у (стр. б) даже льтомь. Очень возмож-

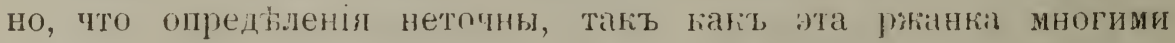

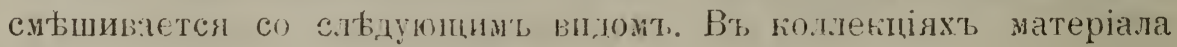
н古Ts. 


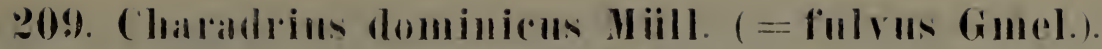

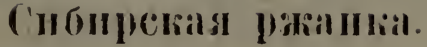

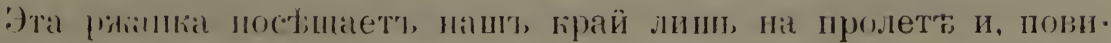

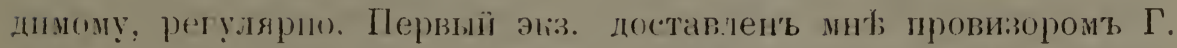
А. ПІтромбер гомъ и уонть подь Барнауломъ 13 гх 1899 г.

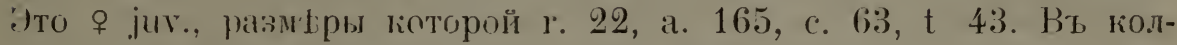

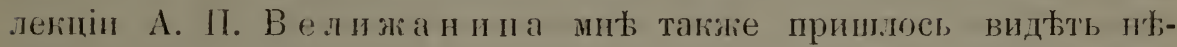
екольдо эн.. әторо внда, убитыхъ подъ Барнауломъ. Близъ Каин-

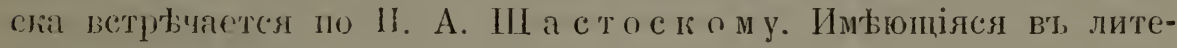
paтуры указанія о нахожденіи этого вида въ предълахъ нашего края крайне недостаточны. А. М. Н и кольск ій (стр. 204) получиль одинъ экз. этого вида, убитый близъ Усть-Каменогорска. Друтихт, указаній н安ть.

\section{⒑ Charadrius morinellus Limn. I'Jỵng cubra.}

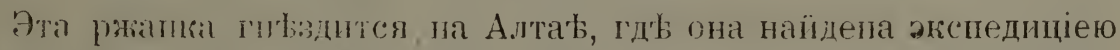
проф. Н. О. Ка ш е и о 1898 г. (см. жтр. 96 его „Результатовъ“). По Э. А. Ә в ер с анну (Естеств. Истор. Оренбурскаго края

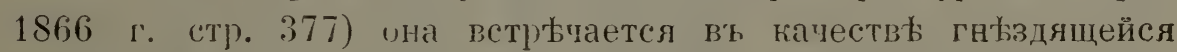
птпиы .даже घ' очень южныхт мьстахь подъ $44^{\circ}$ или $45^{\circ}$ с. ш., какт папр. вт горахт Ала-Тау“. Мнб непзвьстно ни одного случая, доказыванцато гнћздовапіе этого вида въ степной части нашего грая. На шролеты же сивка встрычается. Изжьрит я могь

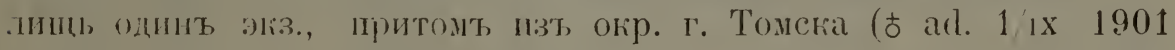
г. 16 а. 15.3 с. ? t. 3ј). Найдена И. С лов цовы м ъ (стр. 153) ІІ А. Морозовы и (стр. 6) подъ Омсконъ, В. Н. Плот нико вы ш в (стр. 14) на Иртышь до окончанія пахоты, П. Г.

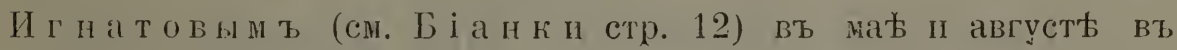
Акмолинскомь и Кокчетавскомъ уђздахъ. Всъ приведенные случаи це доказывають ея гнъзлованія въ степной части нашего края.

\section{- Charadrius asiaticus Pall. Зуеќ, lacmin̈eriü.}

liponts „nomen nudum" въ спнскь F. Blandtia (стр. 444) для Западной Сио́ири приводител лишь Б і а н к и (стя. 12) для Атбасарскаго уьзда Акмолинской области на основанін молоді:хъ птицъ „вь первомь перовомъ нарядь“, добытыхъ экспедиціею

П. Г. Игн а тов а 30 , vi 99 г.

Въ степной части нашего края пока не добытъ. 


\section{Charadrins dubius S(op) (= minor Meyer et Wolf).

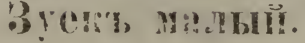

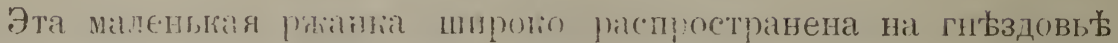

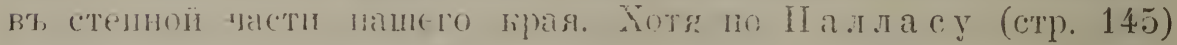

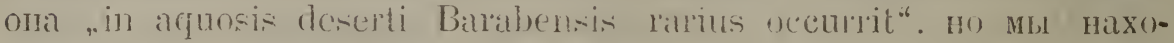

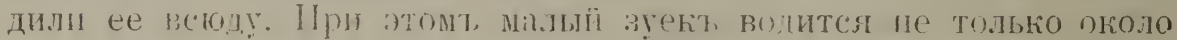

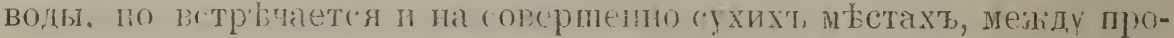

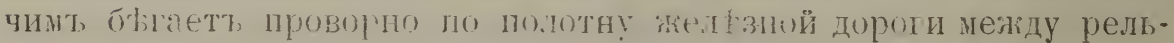

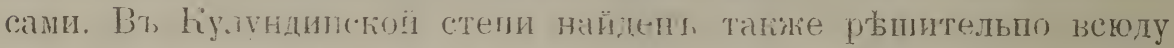

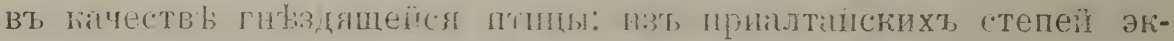

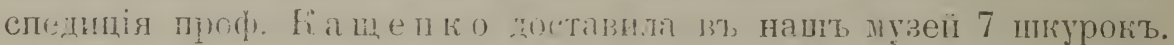

Экаемилнры тинценцін:

1) sex? ad. (. Tofiot, 13 vo 01014 a.d $110 \mathrm{a.s} 112 \mathrm{c.65}$ t. 24 uk.

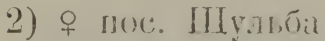

21 vi 0013,5111

1116125 .

3) む

2:3 VI $0(0) 13 \quad 111$

1106325

4) 우

23 以 0 (4) 110

114 วิ 25

5)

$2: 3 v_{1}(1) \quad 1: 3 \quad 110$

$11501,527 \%$

6)

23 vi $00 \quad 13 \quad 117$

1176325

7) 우 с. Уúnncrioe 26 vis $0012 \quad 11$

$110 \quad 6: 32: 3$

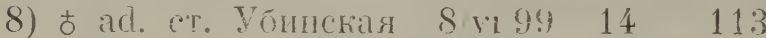

- 5923 ,

9)

9 พ. 9? $94,5 \quad 111$

10) ᄒ ad. (т. Fo'енево 1 vл 99 13,5 112

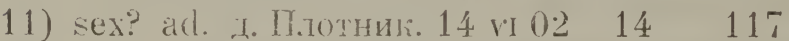

12) sex? ad. (. Вылково 17/vi 02 1:) 114

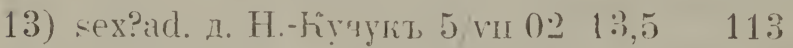

14) sех?ad. ст. Семиярск. 22 гпо2 $14 \quad 110$

- 6124 ,

- 5724,

- 6:3 24 MyM.

- is 2:3"

- $6025 \%$

$-5923 \%$

\section{- Charudrius alexandrinus Limn. Moprroŭ вуer'.}

Этоть зуект, намь не попадался и въ коллекціяхъ экз. нотть. Хотя Па ллась (стр. 143) говорить „in citeriore Sibiria et Rossia nunquam visus", но экспедиціею П. Г. И гн а т о а найденъ на соленыхт озерахь Акмолинской области (см. В. Б і а н к и стр. 1.3)

\section{Hacmatopus ostralegus Linn. Ky.mk b-copora.}

Куликт-сорока по рбикам Западной Сибири очень распростра-

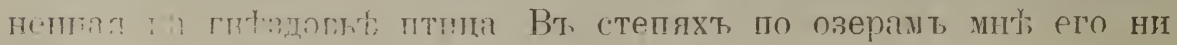


разу пе приходилось видыть и онт, пажется, частью замьнен

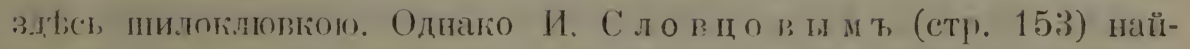
дент. иа ижном берегу озера Чаны, а эгспедиціеи Игн атова цобытт, иа небольшом' пзерю въ Агмоли:ской иоласти (см. Бізнги етр. 11). Во гремі потздокъ по Бараб́б намъ не попадался. Найцент на Оби и нд Иртыш (с. Тулинское, Барнауль и стан. Семиярскал). Эгспедиціею проф. Н. Ө. Кащ е нко добып оголо стан. ПІульы.

Измиренія:

1) t ad. Барнаулт 3 г. 98 r. 83 a. 260 c. ? t. 53

2) o al. c. Tyлnнское 21 r $96 \quad 94 \quad 260 \quad 110 \quad 53$

3) q ad. ст. Нульба 22 и $00 \quad 97 \quad 261 \quad 112 \quad 53$

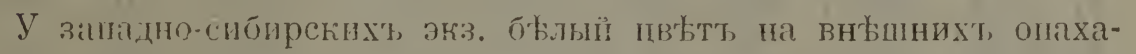

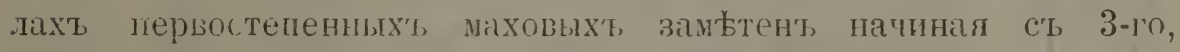
иногда даже со 2-го махового, мезіду тьмъ капт, С А. Бутурлинъ

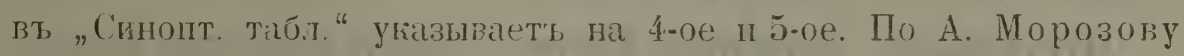

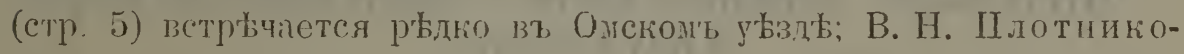
вымъ (стр. 15) нао̆людался 10 Иртышу. Шо И. Я. Словцов у (стр. 15:3) встртуается ежегодно и льтом' близъ Омска, но въ Кокчетавскомь у. не найденъ.

\section{Recurvirostra arocetta Linn. HInolisюbra.}

Шилоклювка одиа изъ характериыхъ птицъ, паселяюпихь берега горько-соленыхъ озерь нашего края въ предъ.тахъ Кулундинской степи. О нахождепіи ся въ Барабинской п приалтай-

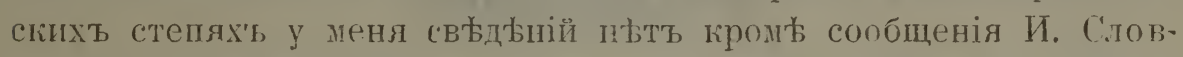
ц о ва (стр. 155), нашедшаго ее на соненахъ озерахъ по южнму берегу Чановъ. Палласу (стр. 160) оп извљстна была съ Иртыша, O. Fins ch (стү). 251) находиль ее на Сасык-Алакулћ, общее ея распространеніе вт, Азіатской и Евпопейской Россіи характеризують проф. М. Мензбирт (стр. 338) п С. А. Бутурлинт (стр. 르). По А. Моровову (стр. б) ветрьчается она на югт, Омскаго у. довольно часто, въ окр. Омска по рғчкамъ Солоновкь и Камынловкь. Для Омскаго у. приводитея и В. С. Ел пат ьев с ки т (стр. 140). По В. Н. Плотникову (стр. 15) найдепь только разъ одиночный экз. въ окрестн. Ямышевскаго поселга. М. Д. Рузски м в найдена въ южной полосж; 


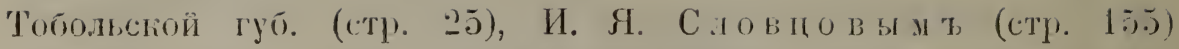

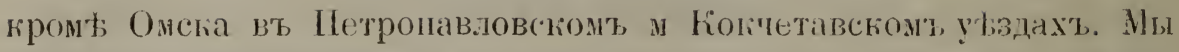
находили шилоклювокъ на устьядт, каћъ ए. Кулунды, такь и Степного Кучука. Мололыхъ шилокловок'ь здьсь не прихолилось,

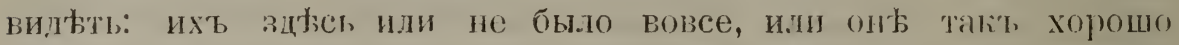
прятались, что оставались соверненно незамъченными. Нъкоторья

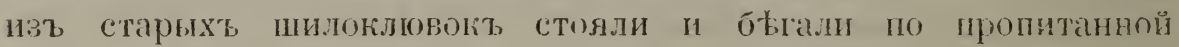
сольи почв'b этихъ де.лтъ въ оригинальныхъ позахъ, съ приподнятыми кверху ғрыльями, всльдствіе чего казались вдвое болише. Въ Павлодарскомь у. Сенпплатинской обл. пилоклнвки найденц нами на озерь, Маралді.

Экземпляры коллекціи:

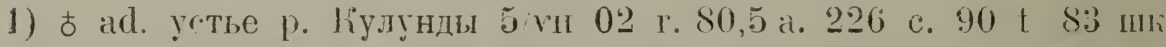

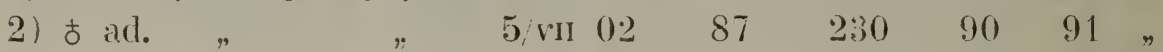

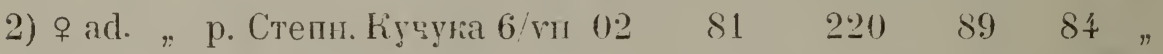

\section{- Iimantopus cumdidus Bonn. (= melamopterns Meyer). Ходу.}

Ходулочнико по II алла с у (стр. 186) .nsque arl Jrtin fl. in deserto tatarico australi“. O. Finsch (етр. 253) находиль его на Сасык-А.такуль. Iор А. Mорозов у (стр. 5) ветрбчень на санов югь Омскаго убзда. Нами нигды во время нашихт повздокъ не найдепт.

\section{Sumenius aroutus lineatus Cur. Kiponumen' 60.7,-

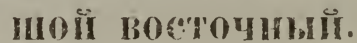

Мъстн. назв.: „куликљ-паховикъ “ (дер. Плотникова).

Въ степной части нашего края эта разновидность большого кроншнепа весьма обыкновенна на пићздовьъ. Изъ Барабинской степи

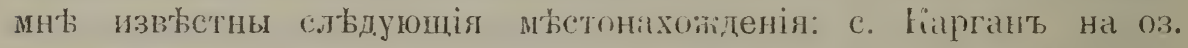
Убанскомғ, окр. ет. Убннский, өт. Татірекой, т. Каинска. Во время поъздки по Кулундинской степи болиой кроншнепь по. падался доводыо часто. Уже около дер. Плотиновой кронинеловт, мнго, по чнсло ихъ значительно узеличивается, если отъьхать ньскольго въ открытую степь. Вмбсть съ большими веретенниками они налетали на сопровождавщую наст собаку и ихъ нетруди был бить в.теть Вз степи петду дер. Чистоверской 


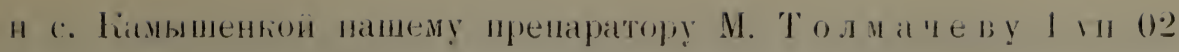
ностастливидсеь пайти на дорог'

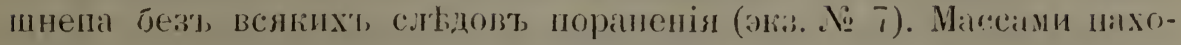

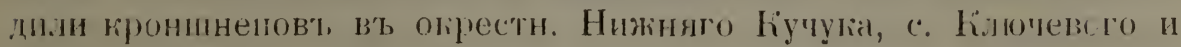
пі) Иртыну (стан. Семчярская). (чен, обыкновенная птица долины Оби до Барнаула; изъ приаттйскнхт, стеней доставлень әъспе-

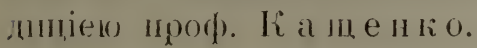

И:зтренія экземпляровт поллекціӥ:

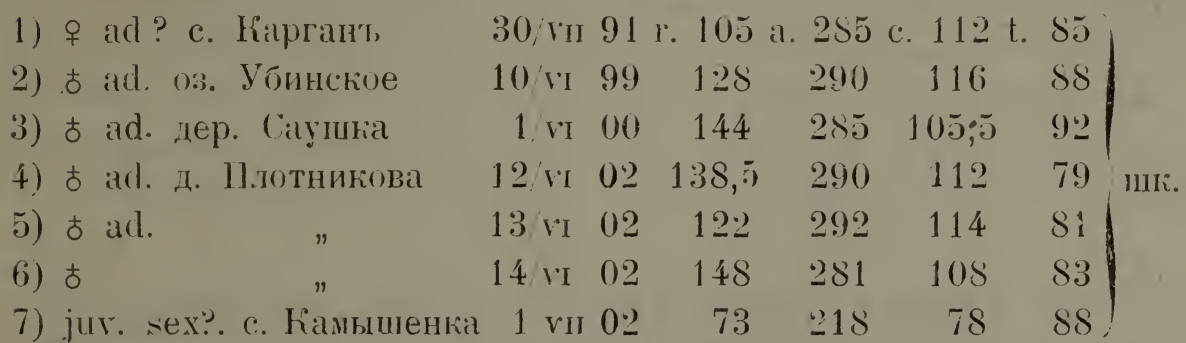

8) sex?. (т. Семиярская 12 \% 02 culmen $! 88$ (Әкспедипіею прол).

B. В. Сапожникова доставлент, лишь черепъ).

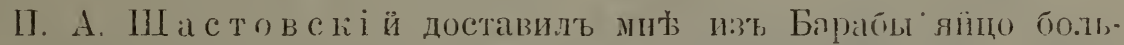

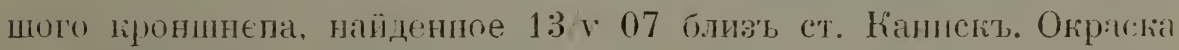
его болье всего похоцит на рис. 4 табл. 33 Nammann’a, но

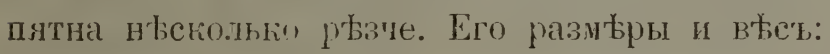

$$
\frac{67,3 \times 47,0 \text { мм. }}{4,92 \text { гр. }}
$$

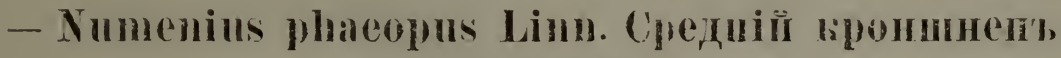 ванадниї.}

По А. Морозову (стр. б) вмбосты ст, сородичами „обычныя формы на солончакахт, ". Іриводитея и (стр. 154 и 227) для Тюменскаго округа и Акмолииккой области. Нами въ предълахт, нашего краи пе найленъ.

\section{Nmmenius tenuirostris Vieill. Wasui hpomunems.}

Совершенип неожиданнымт сюрпризомъ для меня был нахожіленіе малаго кроншнепа вблизи сл. Коченево (Сио̆ирск. ж. д.) въ Томскомъ уъздъ, въ мъстности съ пресбладающимъ степнымъ характеромъ близъ небольшого водоема, снабжаюцаго паровозы 


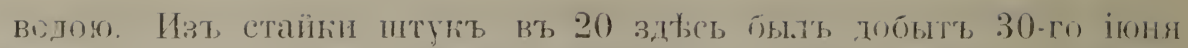
1899 г. одинь экз., опредыльніе потораго было произведено по

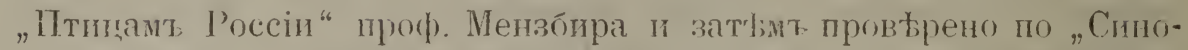

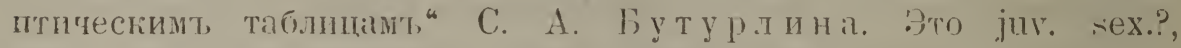

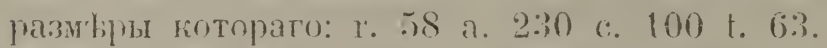

По проф. Мензо ир у (1. с. стр. 326) этотт, видт вт, восточ-

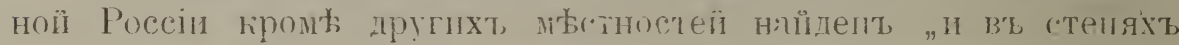

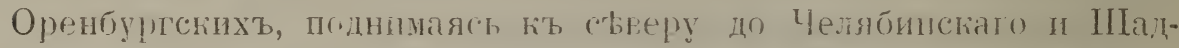

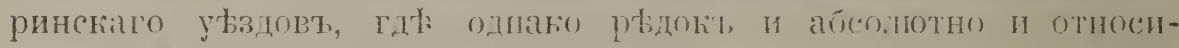

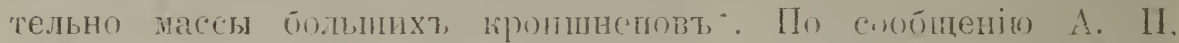

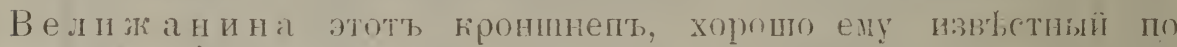

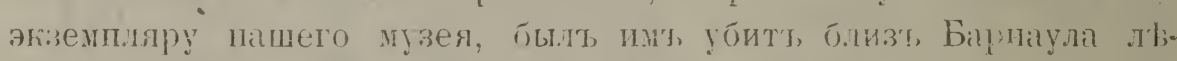
томь 1901 года - Приводитея А. Морозови и (стр ј).

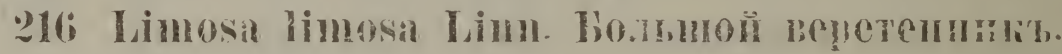

\section{(Limosa melanulad Leisl.)}

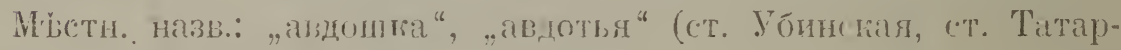
ская, дер. П.лотинғова).

Больной веретенник, очень обыниовенная, гићзднцаяся въ

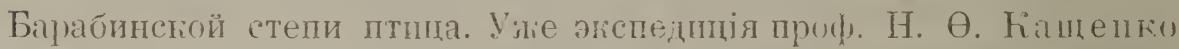
1891 г. доставила въ нашт музей одинъ әгї. изъ д. Кванниной. Вт, 1899 г. мы паходили этого веретеннияа в', Барабипсной степи въ значительномь количесть⿱丶万仒 около sh. т. станцій Jónнской и

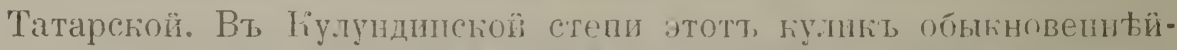
шал птиц въ окрестностяхт, дер. Плитниюовой. Вы вромя әюскурсіи, предпринятой мнои 14-го іюна 190.2 года изт этой деревни къ располовкенным къ Nо-отъ нея большия озерамь (Няшино, Тараторино и Барсучье) я былт, поражень множествомъ веретенниковъ въ степи. Со всбхь сторонъ они прклетали и' нант, бњгали по дорогт впереди нашеуо эншажа, подетали ариина па два, па три к’’ нажъ и къ лошадямъ; не отставая отъ насъ, они провожали нась на зиачительой части пашего пути, оглашая воздухъ свойт крикомт. Особенно привлекала ихъ вниманіе сопровољдавшая пасъ во время әтой экскурсіи собака нашего проводника. Ихъ можно было настрьлять каюеугодно число, чего мы, разумъется, не дълали. Махая крыльями и не перестівая кричать хриплыми голосами, эта ('ия итицъ, 


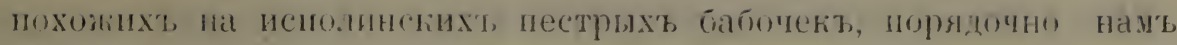

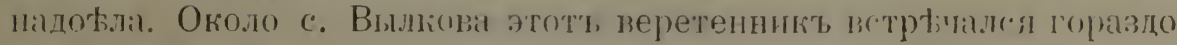

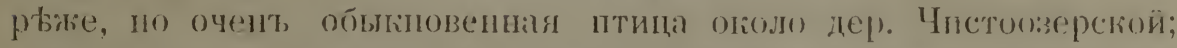

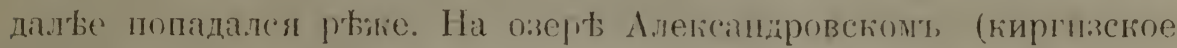

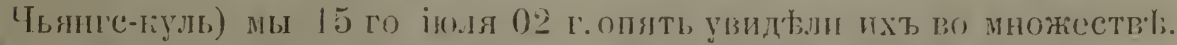

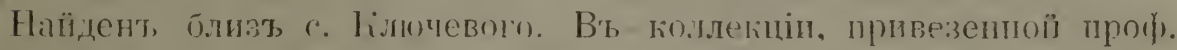

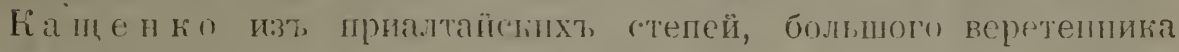
не оказались,

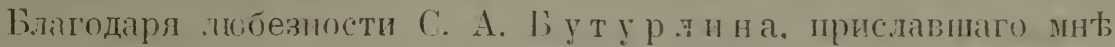

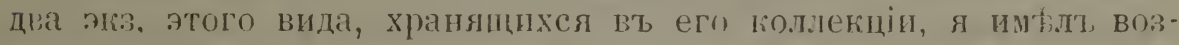
можность сравнить экз. нашей коллекціи сьь болье запапнии. Что מаслется оюраски, то пулундинскій веретенині гораздо

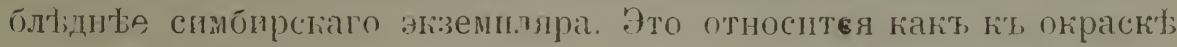
нижней стороны, въ особенности рызаго цвъта зобя, такь и верхней стороны. Окрасъ экземпляра пз, Тургайской области еще болье тенный. Эта особенность заиьиаетя каюь на рыжнхъ частяхъ оперенія, тап' и на темныхт спинныхт пятнахь, которыя здысь выражены ирайне рызко.

Разница въ размтрахт видна изт таблички изметреній:

1) sex? д. Гіьашинина

2) о ad. ст. Тітарская

3) $ᄒ$ ad.

4) ᄒ ad. д. Плотнинова
20 ril 91 1. 87 a. 214 (. 83 t. 80 mil. $16 / \mathrm{VI} \quad 99 \quad 104 \quad 215 \quad 8678$, 17 г $99 \quad 117 \quad 217 \quad 85 \quad 95(!)$ 12 ri 02 $94 \quad 217$

5) sex? Тургайск. обл. Кустанай ?

6) ㅇ ad. Симбирек. г. с. Лава 17 Ir 00

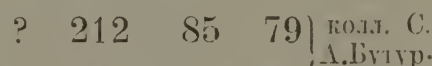
111217 S:3 $\left.80\right|^{-1.1 и ̆ . ~}$
12 гг 02124 (взять только черепть).

Проф. М. А. М е н зб и рт (Птицы Россіи стр. 265) утверждаетъ, что „въ Западной Сибири веретенникъ гнъздитея къ сь̌веру до $60^{\circ}$ с. ш. и па востокъ до Иртыша“. По Бутурлину (Синопт. табл. стр. 30) этотъ куликъ тоже „на востоғъ не доходитъ ло Оби“. Результатомъ нашихъ изсльдований является, слььовательно, нбкоторое расширеніе области гнбъдовья веретенника. Дер. Плотникова, гдь мы нашли веретенниковъ въ огромномъ числь, всего въ 37 в. отъ с. Камень на Оби. Напрямикъ это разстояніе еще меньше. 


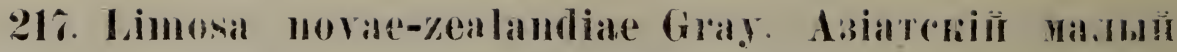 веретенини'ь.}

$$
\text { (= moprgialis (ionld.) }
$$

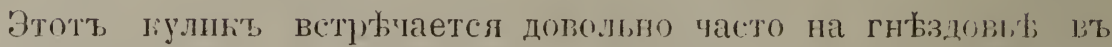
hулундинкой степи около степныхт изерт, близт дер. Плотни-

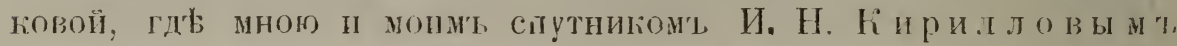

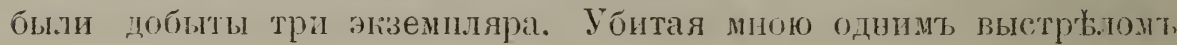

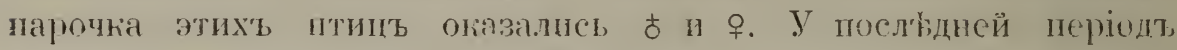

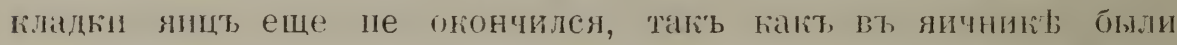
очень ғрушыя яйц. Въ оперенін брюшной стороны нелия был

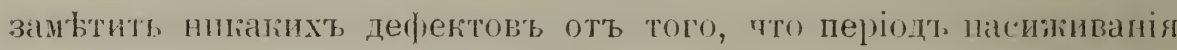
ภнцт, уюе нача.яя.

Нахожденіе әтой формы малаго веретенника въ предьлахъ нашего края в'ь качесты гнғздяцейся птицы прелстав.ляеть неманый интересъ, тапь лакъ об.татыю гнъздовья его до сих считаютея „тундры Вост. Сибири съ Тайлырскаю полуо-ва вклн-

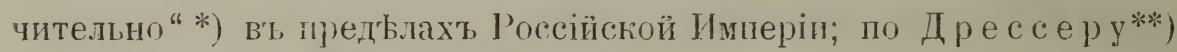
этотт куликъ найденъ ғромы того на Аляск' о-вахт, въ Монголіи, Лпоніи, Корейскомт полуо-вь; на пролеть; найденъ по побережью южнаго Ғитая, Малайскаго архипелаха. въ Австраліи и Новой Зеландіи.

Oть европейскаго малаго веретенника (L. lapponica L. -: rufa Briss.) наша птица отличается тьмь, что у ней „нижшяя часть спины и надхвостье покрыты темными перьяни ст бызозатыми

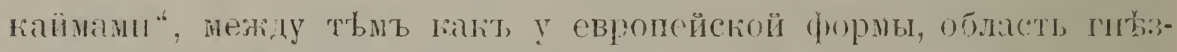
довья которой также заходить въ Западную Сибирь, эти перынки ииьють только темноватые центры, при бьлой окрасюl пера. По Прес се ру и Бутурлину (in litt.) подмшшечны нашей fормы рьвзко полосаты, а у европейскаго малаго веретенника только въ пятнахт, хотя и образующихъ нербдко какъ би поперетнуп полосатость. С. А. Бу т ур.пинъ съ моимь сиреды; лепіемь виолиь согласень. Полғзуюсь случаен ш здысь ему принести искреннюю благодарность за пједоставленный мн вे изы,

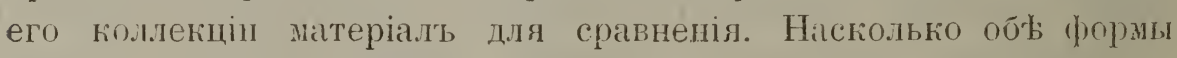

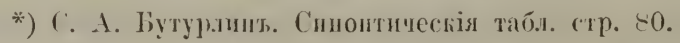

*) H. E. Dresser. A manual of palaearctic hirds pag. 798 . 


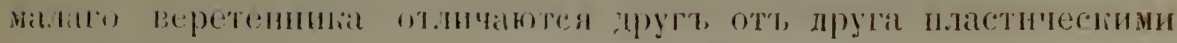

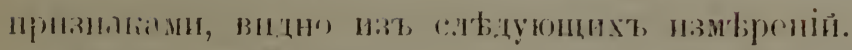

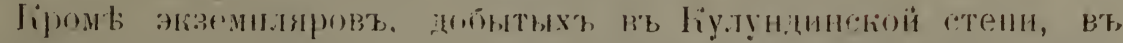

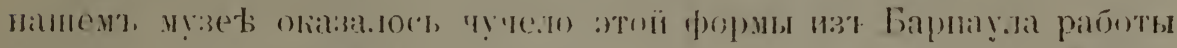

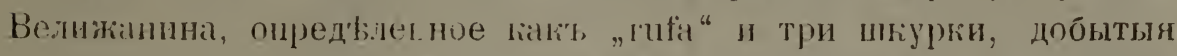

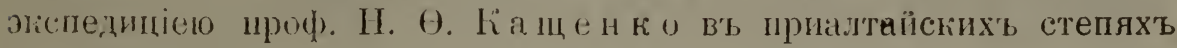
B'b 1900 rorty.

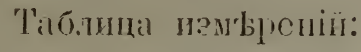

Limosa novae-zealandiae.
1) sех? ad. Барнауль
5 VI 97 r. 85,5 a. 170 c 71 t. 53

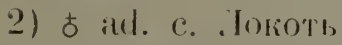
9 ฯ 00
$8: 3$
$170 \quad 66650,5$
3) o adl.
$\begin{array}{llll}87 & 175-178 & 77 & 53\end{array}$
4) 古 $\mathrm{adl}$.
.
$90 \quad 174-178 \quad 65 \quad 53,5$
5) $\delta$ ad. дер. Плотникова.
6) $q$ ad
14. I. 02
80
174
$65 \quad 50$
7) $t$ adl.
$"$
$"$
83
176
$65 \quad 50$
$81 \quad 168,5 \quad 66 \quad 48$

Linosa lapponica
1) む О-въ Эландъ
$26 /$ sn 95
77
211
$71 \quad 47$

Лксльдній әкз. вт коллекціи С. А. Бу ту р лин а.

Что касается нахонденія европейскаго малаго веретенника (L. lapponica L.) в'ъ Западной Сибири, то уже ПІ л л а сь говоритъ "per Sibiria mihi nunquam ohlata" (pag. 180). у новьйшихъ пзылдователей (М. Д. Рузскій, В. Н. Плотниковт, А. Моро.

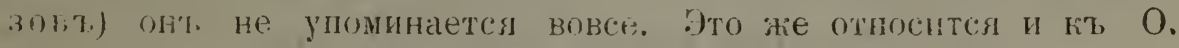
Fins ch. Одинт только И. Я. С.л о вцов в (стр. 228) приводи'r'b „rufa" для окрестностей Тюмени. $\mathrm{O}$ нахожнденіи малаго веретенниа въ Барабинской степи пока нпчего не извґстно.

\section{Terekia cinerea Guild. Mopoдyma.}

Mopnдунка принадлежить гт, довольн часто встрььяюцимся в степной части нашего края куличкам’ь. Она найцена въ , Барабинской и Кулундинской степяхъ, въ окрестн. Барнаула и близ'ь $\therefore$ Тулинскаго на Ойи.

Въ приалтийсиих степяхъ замъчена на оверғ близғ д. Бородучихи 18 เ 00. 
Экземпляры коллекции:

1) ㅇ ad. ст. Коченево

4. vil 99 r. 46 a. 131 c. 56 t. 30 mil.

2) sex: ad. с. Bu.tiono

$17 \times 102$

$47,5 \quad 127$

.)

28 мум.

3) sex. pull. д. П.итникова 12 г 02

2.5

5.)

26 핑.

4) sex: pull.

5) sex? pull.

$22 \quad 56$

26 mys.

2.2

.) 1

23

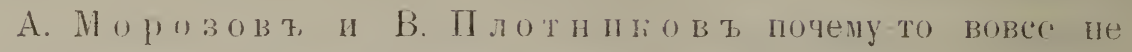

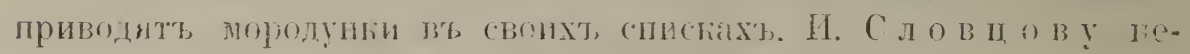

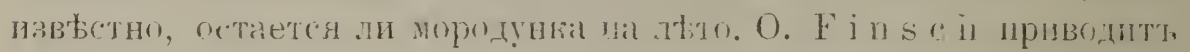
мородунку только дия ствера Тобольскої туб.

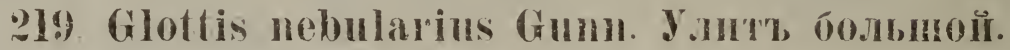

\section{( Totanus littoreus Limn.)}

По свидъ̆тельству Б. П. Бі ан ки (стр. 14) наидент әкспедиціею И г н т о ва въ Ағмлииском', утзды, а И. Сяовцовымт,

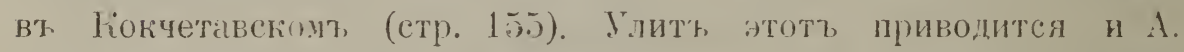

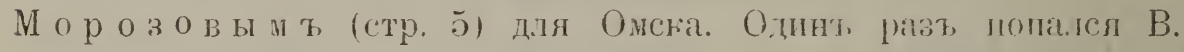

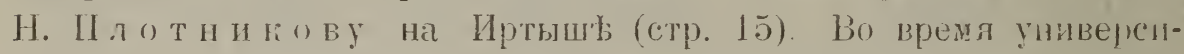
тетскихъ экспедицй въ степий тасти нашего края этоть кулинт, замьчень аншь иа озерь олизт д. Бородулихи $18 \% 00$, но

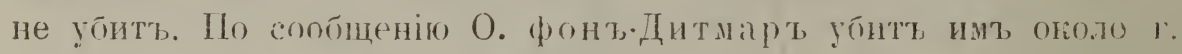

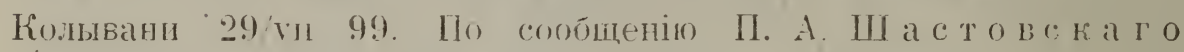
гнђздитея подъ Кінинском'

\section{?20. Totanus fuscus Linu. IILevo.u.}

Свъдъній о распространеніи этого кулика въ степной части нашего ғрая у меня немного. Во время поъздки проф. Н. Ө. К а ще н ко в’ Барабинскую степь в'ь 1891 г. этотт, видъ былъ найденъ близъ с. Карганъ. Экспедиціею И г на то в а найденъ в'九 Омском' убзды (В. Л. Б і а нк и стр. 13). Приводится С.товцовымы (стр. 155) и Морозовы мь (стр. 5) для Омска. По Словцову (стр. 227) въ Тюменскомь убздь, ,на пролеть большими стайками, на льто остается въ небольномт, количествь".

Экземп. коллекиіи:

1) sex? с. Каргант, 31 ril 91 r. 56 a. 1602 с. 73 t. 59 шнуркат. 


\title{
gel. Totanms calidris Limn. T'равник'т.
}

\author{
(Totanus totamus limm.)
}

Травникъ встрғчается гораздо таце предыдущаго. Въ Барабинской степи найдсцъ вт, оюр. ст. Lіпуенево, гд'ь молодыхт травниковт, З-го інля 99 г. было доволыно мпого. Въ Кулундин-

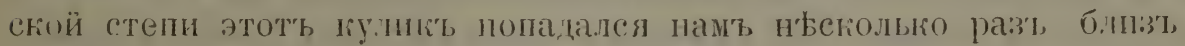

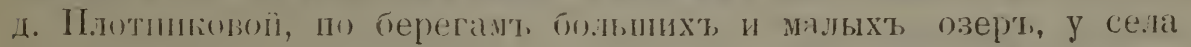

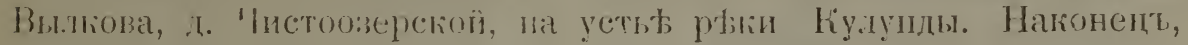

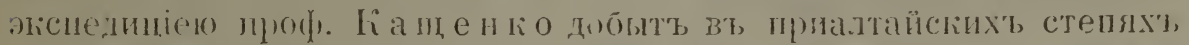
и А ІІ. Вели ия анин и мо близт Барнаула.

Нквемплиы кольекціи:

1) sex? at. Барнауль ? у 97 1. 45,5 а. 160 с. 69 1. 49 чуч.

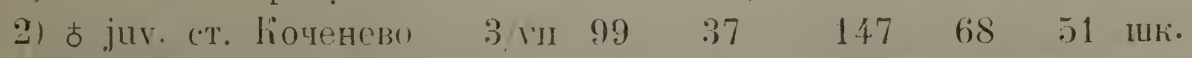

3) ᄒ аd. с. Локоть 9) и 00 4.6 $152-15663,5$ 55 "

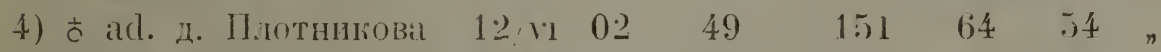

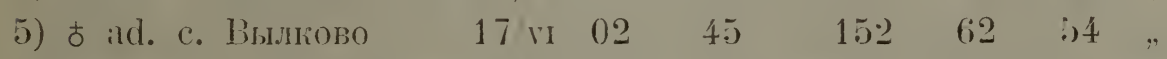

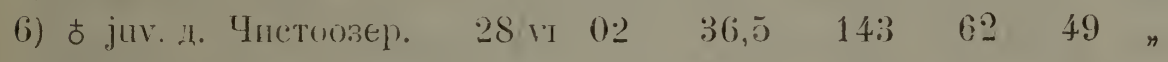

7) sex? jur. " " $\quad 37.5 \quad 139 \quad 63$ 52,

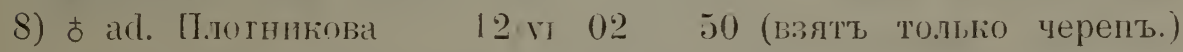

\section{? Totanus incanus Guel. Ilene.mbü̆ y.n'tb.}

П алласъ на стр. 194 своего внаменитаго труда подъ названіемъ "Trynga glaregla " говорить о рғдқомт пахожденіи въ Барабинской степи кулика, который съ его словт, подъ названіемт, "Totanus pulverulentus Mäll." приводитея, межія прочимт, и ц-рохт, Г. И. Радде (стр. 326) для Западной Сийнри, в’ частиости дия Барабы. Это назване не болье какъ синоний incams (imel. O pacпространеніи incanus нахоку у Бут урлин а (стр. 27) линь указаніе на полуо-въ Чукчей и Командорсгіе о-ва. Нами этотъ куликъ въ изсльдуемой мъстности нигдђ не найденъ и әкземпляровт въ голлекціяхъ нбтъ.

\section{y92. Totanus glareola Linn. Фи()и.}

Этотъ, нироко распространенный во всей империи куличекъ гиъздится и въ степной части напего края. Въ Барабинской степи онъ нами найденъ в’ь востотной ея части, гдъ близъ ст. 


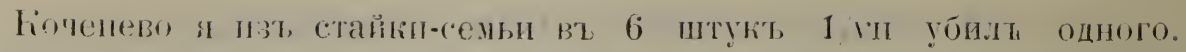

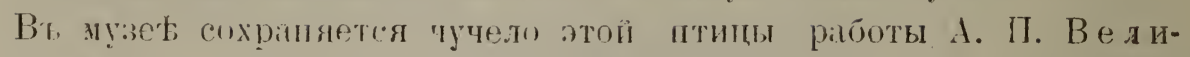

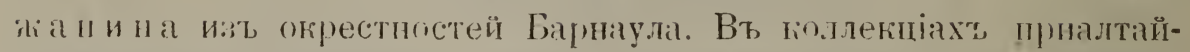

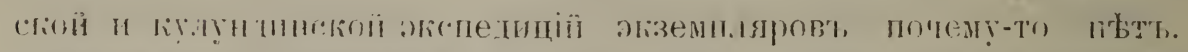

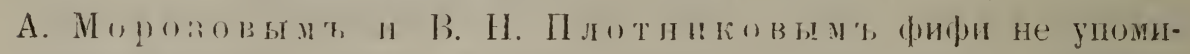
нается вонсе. (). Finsch (cт). 250 приводить его дыя Семипалатинска и Омека, И. Словцовь (стр. 155) для Омска и Акмолинской ооласти.

Экзенпляри колтенци:

1) б ad. ст. Коченево 1 ки 99 г. 27 а. 116 с. 50 t. 38 шк.

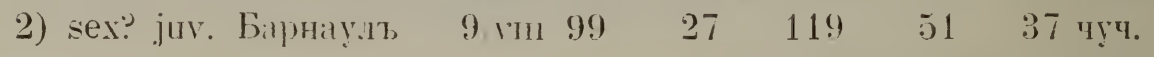

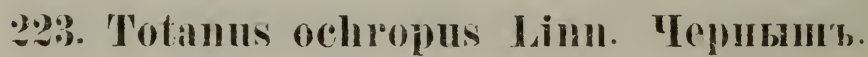

Чернышъ найдень вь Барабинской степи на всемт протядіеніи жельзной дороти оть сю. Юоченево до Омска, а иненно на

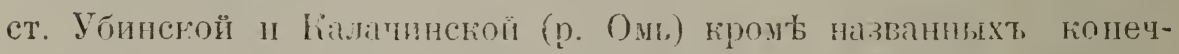
ныхъ. Въ Кулундннской стени гнъздися баизъ дер. Чистоозер-

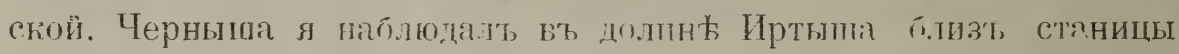
Семиялской, а затынь ст, парохода. 1-го авгеста 1902 г. выше гор. Павлодара. Найдепь близь Барнаула.

Экземпллиы кол.текиін:

1) む ст. Налачинскіия 25 1. 99 1. 34 a. 138 c. 611 1. 35 шк. 2) о дер. Чистоозеркюка .) VI 02 36 14.5 5 () $: ; 6$

\section{2:4. Totanus stagnatilis Bechet. Uоругейнй.}

Поругейникъ принілдежить кт гньздянимся, хотя и в'т сравнительно небольшемъ числь особей, птипаж, степной части нашего края. Въ Кіулундинкой степи мнб онъ извђстент, какт, найдениая близт дер. Плотниковпй птица. Вт, окр. д. Чистюозерской онь намь попадался парочками и отдельными осопями. До-

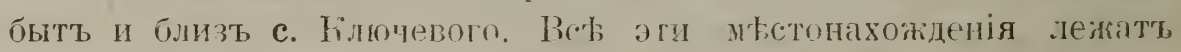

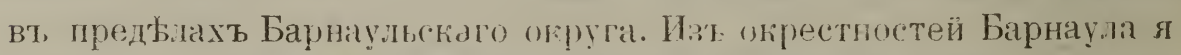
также полуги.т әвземплярт. На Иртышы он нами найцент близт стан. Семиярской. По С. А Бутурлину (Синоптич. табл. стр. 29) онъ жгньздитея въ южной Сибири..... Въ пассейнћ Оби кт сыв. встрбчается епе въ Барнаульскомт округы ". Наши изсльдованія оопаружн.ли егі присутствіе в', окр. (“тал. Lолтенево 


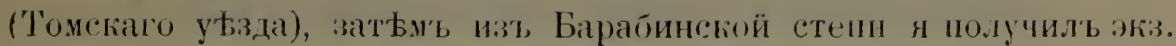

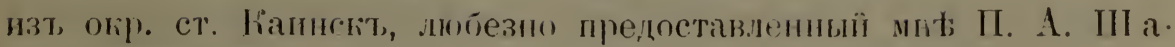
с тов С К и м'

Экземпияры коллекиіиі:

1) б ad. Барн. у. д. Чистооз. 24/ง 02 r. 41 а. 135 с. 60 t. 55 шк.

2) б јим. " с. Ключевое 11 гі $02 \quad 37 \quad 140 \quad 57 \quad 49$ "

3) sex? juv. ст. Семиярская 23/vil $02 \quad 40 \quad 135 \quad 58 \quad 52$,

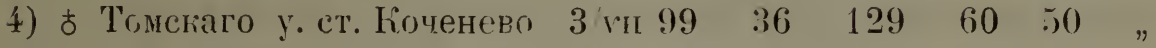

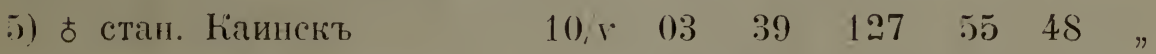

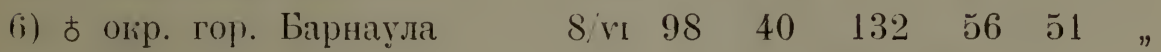

По О. Fins ch (стр. 250), И. Словцову (стр. 155) и В. Ельпат ье в скому (стр. 139) поручейникт, встрьчается око.о Омска. А. Морозовъ пе приводить его однако для района его изсльдованій. В. Н. Пло тни ко въ (стр. 15) нашелъ его в’ь долин' Иртыша, но рбже сородичей. Среди позвоночныхъ Тюменскаго округа И. я. Словцовымъ не упоминаетсл, но найденъ имт еъ Акмоаниской эблтети (Кокчетавск. ушздъ).

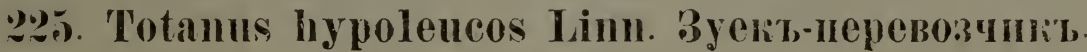

Область растіространенія этого куличка вт, степной части нашего края довольно обширна. ('тепная экспедиція проф. Н. Ө. К а ще н ко добыла экз. этоге вида близъ с. Локоть. Изт окр. г. Барнаула я также получиль әкз. Въ Кулундинской степи найденъ вт. ... Чистоозерской

Въ Барабинской степи, навърнне, әтотъ куличекъ также гиґздится, хотя въ коллекціяхъ матеріала оттуда ньть.

Экземпляры коллекціи:

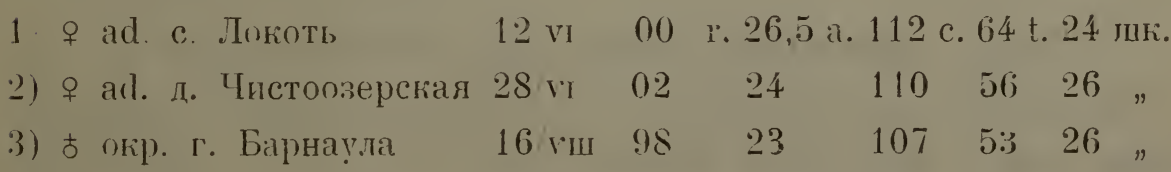

А. Морозову и В. Н. Плотнићов у этоть куличекъ не попалался, но Елпатьевскимғ и Словцовымъ приводитсл для Акщолинской॰ пб.ласти. 


\section{Pavoncella pughax Linu. Tymxtah,}

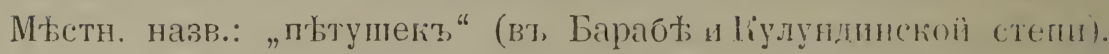

Въ Барабниской степи, повидимому, встрбчается часто, ио г.навнымъ образомъ на пролеть. На әзерь у уинскомъ встрғчается тасто; на ст. Татарской намъ былъ доставленғ 18/г 99 турухтанъ со значительно порђдывшимъ ошейником. Oпереніе было въ такомъ состояніи, что шкурки нельзя было сохранить. Скелеть экз. сохраненъ. Экземпляры безъ ошейниковт, были догыты вт, пачал' іюля на ст. Коченево. Въ Кулундинской степи на пролеть; встрбъчается несомньнно. По сообцценію жителей д. Плотниковой и Чистоозерской по озерамъ весною бываетъ много „пђтушковт,". Нами здұсь не быль добытъ. Въ окр. г. Барнаула гстричактся какъ весною, такъ и осенью. Найдент турухтап и в'ь приалтай -

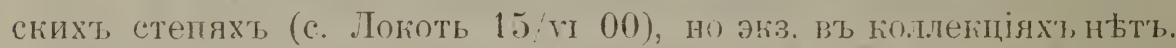

Экземпляъ коллекціи:

1) sex? juv. ст. пீоченево 4/тi 99 г. 31 а. 152 с. 58 t. 44 mк.

По литературнымъ указаніямт весыма сбыкновенная птица в', занадныхъ частяхт, района напихъ изсльдованій. По В. Н. Пло тни иову (стр. 16) не покидаетт, долины Иртыша и льтои'ь. По 1. Сло вц о в (1897 стр. 155) часть, турухтановт остаетея подъ Омскомъ на льто. Найденъ И. Словцовымъ и въ һокчетањ-

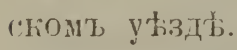

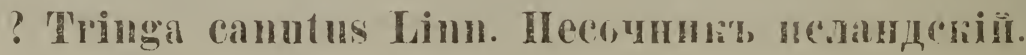

0. Finsch (стр. 251) сообщаетя, что встрбтиль 14-го апру.ля 1876 г. неболин стайги әтого вида по Иртышу приблизительно в'b 260 в. оть Омска. Вт, литератур⿱宀㠯 о пахожденіи әтого вида въ интересующихт, нась частяхъ Западной Сиоици никакихт, указаній ньтя. Брэхенскю әкспедиціею впроем ни однго экз. не было добыто.

\section{? Tringa maritima Brïnn. Ifecounus nopcroñ.}

По свидьтельству Палласа (стр. 190 „Trynga arquatella“) этотъ куликъ найдент, въ Барабипской стеги. Ни у одного изъ авторовъ не нахожу подвержденія этого указаяія. С. А. Бутурлинъ (Кулики стр. 180) относитъ описаніе Палласа частью к'љ сльдующему виду. 


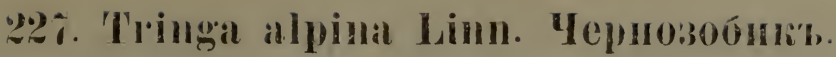

Чернозобикт правнльно посынаетт, окрестиости Томска на

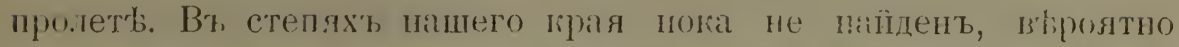
потому, 'тто время лолдекированія не захнатывало его пролетъ.

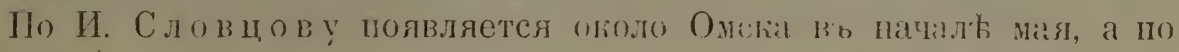

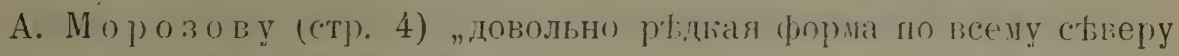
Аћмолинской области". И. Я. С.товцовым' (стр. 2.28) черно-

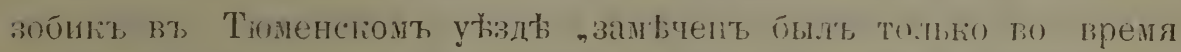
осеништ, перелетовъ ". Восточная форма Tr. alpina parificia Couss пока не пайдена въ прегьйахъ нашего кіля.

\section{S. Tringa minuta Leisl. I ecoчnum-вonoбeñ.}

Этого кулнчка я считаю гнжаздящимсл вТ Барабинской и Кулундинской степяхт. Изт окр. ст. Канискъ я полулиль оть II. А. III астивскаго два экз, добытые имъ 5, гі 1904 года. Близь ст. Коченево онт, быль очень обыкновененъ в', начнль юлл. Также и въ окр. дер. Чистоозерской мы находили его вь конц іюпя маленькими стайпами, штукъ до 20-ти. А. Морозовыз и и. Н. Шлотниковымт кулик'воробей не упоминается вовсе. Но уже И. Я. Словцовъ (стр. 228) указываеть на тп, чтп этпть пуличекъ „ветрычается въ теченіе

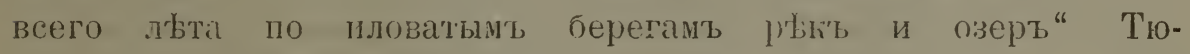
мепскаго округа. Экепедиція II. Г. Игнатова нашла әтихъ

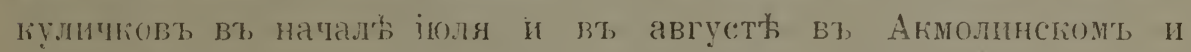

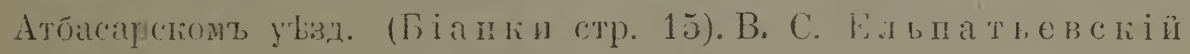

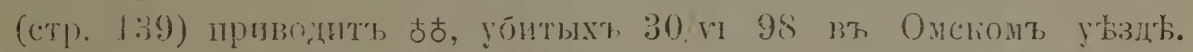

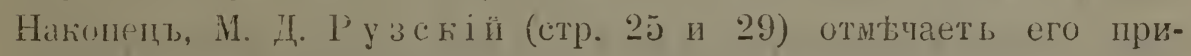
сутствіе „по берегамъ озеръ на грязяхъ, отмеляхъ и мелкихь мъстяхь водњ" въ южной полось Тобольской губ. В’ь Кокчетавскомъ увздй пайденъ 4.го іюля И. Я. Слов пц о ым (етр. 1ә6)

\section{Экземиляры коллекціи: *)}

1) ᄒ ст. Коченево 4 vi 99 г. 18 а. 91 с. 39 t. 20

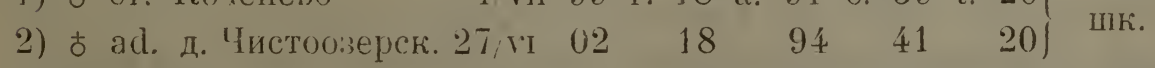

3) sex? ad. " " $\quad 19 \quad 91 \quad 39 \quad 20$ муи.

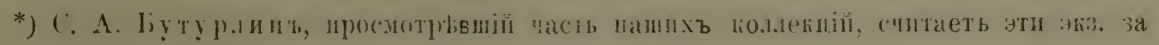

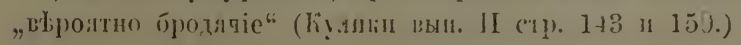




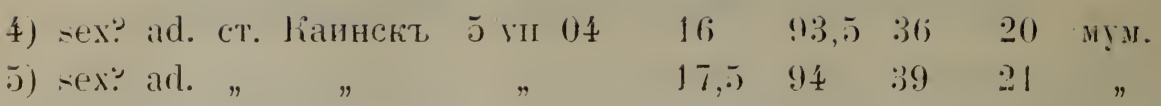

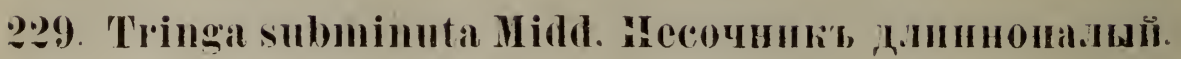

Болыюю неожиданностьн) для меня было при осмотры добытыхъ на ст. Һ゙оченево въ началь іюля песочниіовъ, найти видъ, до сихъ поръ не наблюдавшійея вовсе въ Западной Сио́ири и принадлежкащій вж качеств⿱宀 гнђздящейся птицы лишь наиболье отдаленнымъ мьстностямъ съверо-востпчной Сибири. Д.линнопалый песочиикъ вмьсть съ Tringa minuta большими и маленькими стайками держался около „озера“ близъ названной ж. д. станціи, и мнъ кажется весьма въроятнымт, что оба вида гићздягя гдђнибуды невдалекъ. Этотт песочникт, встрбчается пі блпзъ Барнаула, откуда въ моей частной коллекціи имьется экземпляръ.

Экземпляры коллекцій:

1) о ст. Коченево 4'vi 99 r. 18 а. 89 с. 38 t 20,5 шк.

2) г. Барнауль $14 /$ VII $99 \quad 17 \quad 89-90 \quad 41$ $21 \quad n$

Хајактерными признаками этого вида яв.тяютея:

1) Длина крыла менъе 92 мм.

2) Средний палец съ ногтем длиниъе к.юва. Дина әтого пальца у нашихъ экземпляровъ равняется 24 и 22 мм.

Стериени одного только перваго маха бы.таго цвътта ( дендсрфа сказано , bräunlich weis"s).

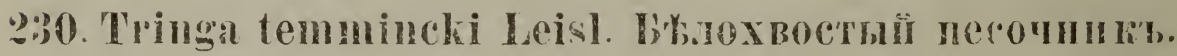

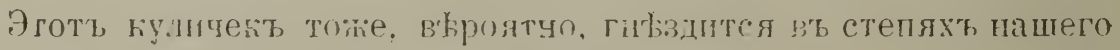

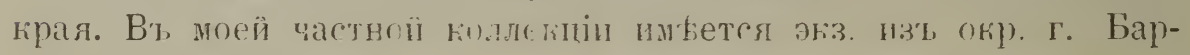

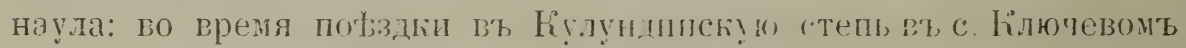
9'кп были замьчены стайки этнхт, куличков?. Изъ одной изъ

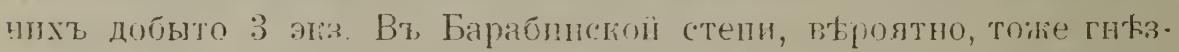

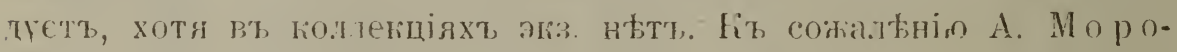
зов в (стр. 4) не сопицаеть, въ капое время этотт, куличекъ

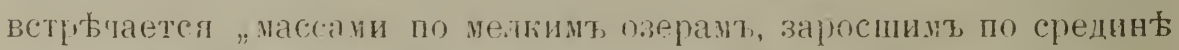

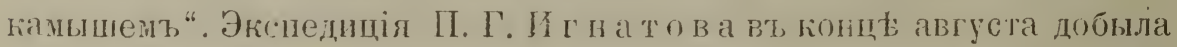

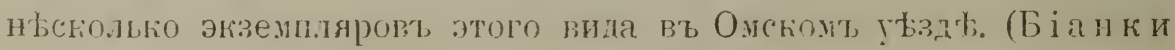




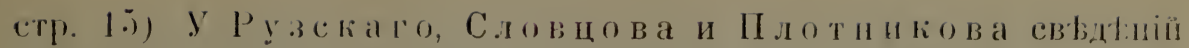

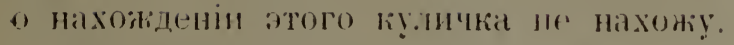

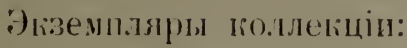

1) ๘ ґ. Барнауль

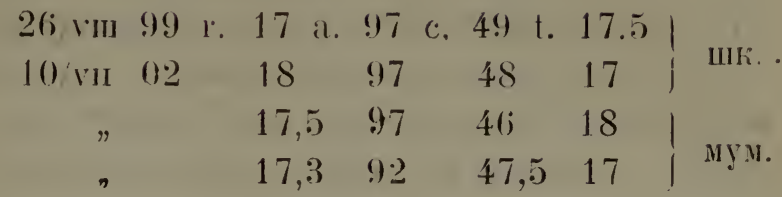

2) 우 c. Kismyebre

3) sex?

4) str?

\section{2:31 Tringa subarcuata Güld. Kpachozoбnk,}

Если не считать устья р. Енисея, гды г-номт P opham найдени мtr.то гићздовія этого кулик. и нћкоторыхъ спорадическихъ

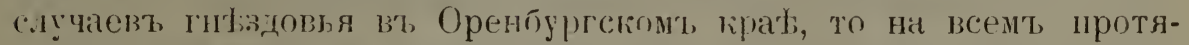

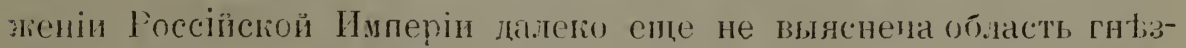
дованія краснозобші. Гнъздится ли этоть кулик въ нашемъ ираь, пока еще неизвъстно, но сроки добычи его, какется, говорять за әто. Бо.инія стап этихт кулюков нами найдены были на озеръ-пруды близь ст. Кіченево. Вา, числь 50-70 особей они перелетали сь одного кониа озера на другой 2-го и 3-го іюля 1899 г. Изъ окр. г. Барнаула я имбль въ рукахъ әкземпляјь въ орачномъ опереніи, уоитый 25-го мая 1898 г. Экземпляръ этоть мною возвращенъ лицу, цобывшему его, причемъ къ

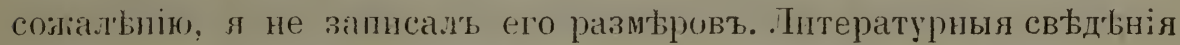
о нахожденіи краснозобика въ нашемъ ғрат весьма скудны. Извъстно лишь, что по А. Морозов у (стр. 4) онъ „довольно рьдкая форма по всему сыверу Акмолинской области “ и что М. Д. Руз скій (стр. 25) нашелъ его въ южной полось Тобольккой губ́ерніл. В. Н. Плотниковымж. этоть куликъ не упоминается вовсе. По И. Слов ио ву (1897 стр. 156) онт, все льто проводитт около озера Зерендинскаго (Акмолинской области).

Экземпляры коллекціш:

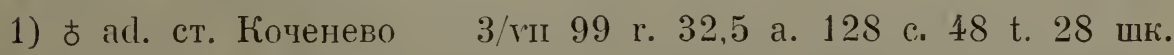
2) 우 ad. " $\quad$ " $40 \quad 130 \quad 53 \quad 31$ чуч.

28:. Phalaropus lobatus Linn. IIлавунчикь круглоносый.

$$
\text { (=Pl. hyperboreus Linn.) }
$$

Въ университетской коллекціи имъется чучело этого плавунчика, доп̆ытаго въ Барабинской степи во время пољздки проф). 
Н. Ө. Каше нко 1891 г. и друге, райоты А. ІІ. Велижанина изъ окр. г. Бирнаула. Я получилт, также әкземпяры изъ Барна• ула и изъ окр. гор. Каинска. Подъ Омскомъ плавунчикъ по И. Стовцову (етр. 157) остается на льто. Шо А. Морозов у этотт куличекъ встрбчатея „стийгами по мелкимь озерамъ съ топкими берегами. Обычная форма въ. степи" (“тр. 5). Къ созкальнію ясныхт указяній на гнбззованіе плавунчика у әтого автора нбтъ. В. Н. Плотниливъ (етр. і6) разъ наблюдаль п.лаунчиковь, но, къ, сожальвнію, дақе мұсяпа не указываєтъ. М. Д. Р узскі й (стр. 24 и 29) нашелт, плавуниковъ въ южной части Тобольской губ. И. Я. Слпвцคв Т, однако, не упомннаетъ объ этомъ куличк' для Тюменскаго огірга. Эғспедиція П. Г. Игнатова добыла этихь птицъ въ мағ и іюльв въ Ғікчетавскомь, Аюмолинскомъ и

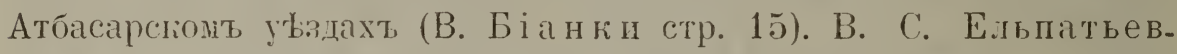
скій (стр. 140) шриводитт, этого плавунтиха для Омскаго уъзда. Экземпляры добыты въ конц; іюня (qо) и въ концы іюля (す). Думаю, что плавунчикъ мьстами гнъздится по степнымь озејамь нашего края.

Экземпляры коллекцій:

1) ᄒ ad. оз. Уо̆инское 30. 1'I 91 r. 22 a. 106 c. 48 t. 20 чуч.

Начало линьки заидтно какъ на шељ, такъ и на спинь.

2) ј јит. Барнауль 28 гш 99 r. 20 а. 101 с. 50 t. 20 чуч.

3) б juv. . . 22. 4) ठ juv. 22 хи $9920 \quad 103 \cdot 102 \quad 48,5 \quad 19,5$ ”

Всъ три эгвемпляра молодые вт первомь перђ.

5) sex? ad. ст. Каинскъ 5́vi 04 r. 21 а. 113 с. 51,5 t. 20 шк. 6) $q \mathrm{ad}$.

7) sex? ad.

8) sex? ad.

$\begin{array}{llll}" & 23 & 110 & 52 \\ " & 21 & 115 & 51,5 \\ " & 20,5 & 108 & 50\end{array}$
20 мум.

Шосльдніе эгземп.яры, пюбезно предоставленные инљ П. А.

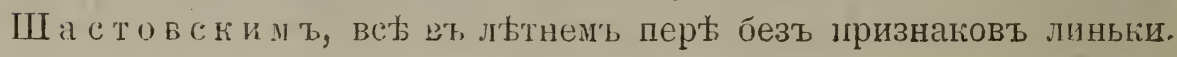

\section{3:3. Neolopax rusticola Linn. Вальдцнеп'.}

Свтдыніи о нахожденіи вальдшнепа вт, степной части пашего грая немпго. Университетскими зкспедиціями не добит экзем-

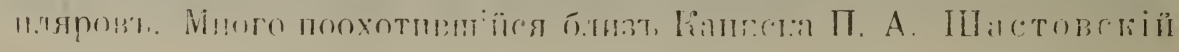


ва.лдднена танъ не находилт. У В. Н. ІІлотиикова и В. Л. Бі н ни не имьется указаній на пахождепіе әтого кулика. Но ysliе А. Миддендорфт в'т, „Isipiptesen“ (стр. 60) приводить

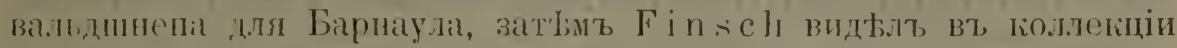
Сло вцова (ср. 1897 г. стр. 156і) әкземпляры изт, окр. Омска (стр. 253.), гд'ь онь поздные найдешь и А. Морозовымғ, (етр. 4)

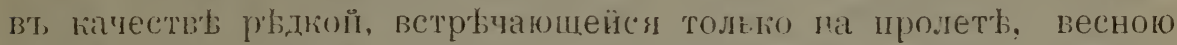
и осень, птицы. Вь южной части Тобольской губерніи найденъ 11. I. Рузскии в (стр. 17) вт, березовых' роцахт. Іаконец

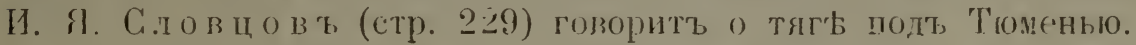

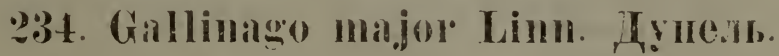

По сопшеню мыстныхъ ихотниковъ дупель не встрбчается оқо.ю стан. Уо̆инской въ Барабинской степи. Въ оюр. станціи hінискт, за пють лють страстнымь охотникомъ быль убить только одинь :кземплярь (по сообщенію II. А. ІШ астов скаго). Но весною 1904 годі П. А. Шастов скому удалось добыть 15-го мая $\delta$ и $q$. ІІкурка $t$ поступила въ мою частную поллекцію; $q$ была черезчуръ разбита, такъ что мнб доставленъ лишь хвостт. Во время пофздки по Кулундинской степи сопровождавшій меня препараторъ М. Д. Толм а чевъ вицьль около д. Плотниковой 12-го іюня лупеля. Къ сожальнію, экз. не былт добытғ, такъ что в’ь коллекціи экз. ньтъ. По сообщенію фельдшера ст. Семиярской Н. М. Фреймунда дупеля по Иртышу водятся, между твмъ какъ вальдшнеповъ и гаршнепов тамъ не бываетъ. Изъ окр. г. Барнаула и изъ с. Тулинскаго на Оби (Барн. уьзда) я получальь дупелей. Экспедиціего проф. Н. $Ө$. К К щ е н ко 1900 г. дупель уб̆итъ близъ с. Локоть $15 /$ г, но экз. не препарированы.

Экземпляръ коллекціи:

1) б ст. Каинскт

15 r 04 r. 68 a. 152 c. 57 t. 40.

По И. (лов цов у (стр. 156) дунель пролетаеть подь Омскомь между 1 и 12 мая. По А. Морозову (стр. 4) дупель гнжздится подъ Омскомъ, но В. Н. Плотниковымъ (стр. 16) на Иртыш'ь встрбченъ только разъ однночный экземплярт. М. Д. Рузскій совершенно не упоминаетъ о дупеляхъ вт своемъ очерк ю южной полоси Тобольский гуо́,, но по И. С лов цову (стр. 228) встрб-

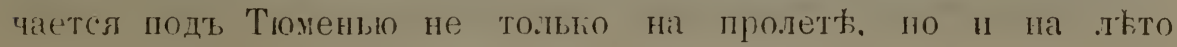


остается въ большомъ количествь. Вь коллекціи П. Г. Игиатпва из'ь Аюмолинской оиласти дупелей ньтъ.

\section{9:3. Gallinggo gallinago Linn. bekacı обыкновенный.}

Въ прпалтайскихь степяхъ (с. Локоть) экспедиціею 1900 г. добыто 5 әкземпляровъ, оставшихся непрепарнрованными.

Вь Барабинской степи я находнлъ бекасов', около ст. Убинской 12 г 99, а также близъ ст. Коченево около озера я лоднялъ 2 үи 99 бекасовъ, но не имья собаки, не смотря на вс: b старанія не могъ добыть ни одного эк:еип.яра. БолЈе счастливъ былъ мой неутомимый помощникъ по коллентированію II. A. Шастовскій, поймавшій близъ ст. Каинскъ 우 этого вида на гньздб 22-го мая 1903 г. и даровавшій ей свободу, сосчитавт у ней предварительно рулевыя (ихъ было 16). Въ гныздь оказалось лишь одно яйцо, любезно предоставленное имъ мнб. Длина яйца 39,3 , ширина 29,4 мм, въсъ гкорлупы 0,76 гр. Къ какому подвиду принадлежатъ барабинскіе бекасы, пока еще не выяснено, но по С. А. Бутурлин у*) (стр. 58) в'т. сбверной части Томской губ., встрьчается еще, „хотя гораздо ръже дупеля“ типичная, вападная форма. Литературныя данныя веђ указываютъ на западную форму, по такъ какт востопная разновидность выдылена лишь въ 1902 г., то они могуть служить лишь для выясненія распро. страненія вида, причемъ весьма интересный вопросъ о распространіи въ предћлахь нашего грая восточной формы придется выяснить при провьркы шваго и болье обширнаго матернала.

Не лишнимъ считаю привести указанія о нахожденіи В' нашихъ степяхъ бекаса вообще. Миддендор(ъ въ своихъ „Isipiptesen “ уже указываеть на Барнауль (стр. 61) и я самъ имбль оттуда экз. Подъ Омскомъ найденъ въ качествъ гнъздящейся птицы И. Словцовым з (стр. 157) и А. Морозовымъ (стр. 4), но В. Н. Плотниковъ (стр. 17) не можетъ утверждать, гнъздуеть ли онъ на Иртышь. Экспедипія П. Г. Игнатов а добыла бекасовъ 1-го и 20-го августа въ Акмолинскомъ и Омскомъ у Бздахъ (В. Л. Біанки стр. 15), но М. Д. Рузскій совершенно не упоминаетъ о бекасъ для южной полосы Тобольской губерніи. И. Я. Словцовымъ (стр. 229) бекаст однако найденъ подь Тюменью, но неизвъстно, гнъздится ли онъ тамъ.

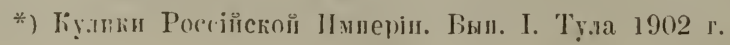




\section{2:36. Gallinago gallinago raddei Buturlin. Bocroчиый Gekic't.}

Около мокраго болота б.изт станцц Семнярской на Иртышь и рано утром'ь 22-го іюля 1902 г. пюдня.и и убиле бекасі. Такъ

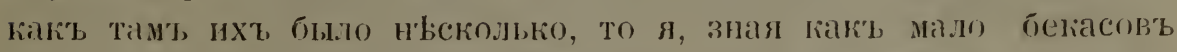
въ коллекціяхъ папего университета " желая собрать ихь побольше, отправился за своия сотрудникомь И. Н. Кирилловымт, хорошимь стрблкомъ. Хотя е’ь нами и не было собали, намъ удалось во время второго посыщенія әтого болота уоить еше по

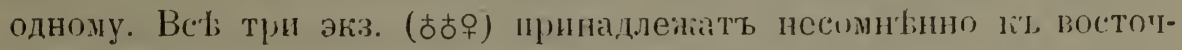
пой разновидности бекаса, описанной и выдъленнй С. А. Бутую. линымъ въ 1902 г. и отличающейсз отт зиалнаго подвида, главнымъ образомт, „болье пирокимн, свттлымп продольными полосами верхней стороны тулювища, имбюшими въ ширнну в' среднемь около 3 мм. (оть 2-4 мм)", мелду тымъ какт ширина этихь полюс'ь у западиой формы в'ь среднем' равняется 2 м..

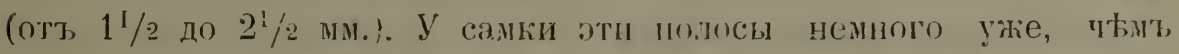
y самцовт, но знатительно шире, чъмъ у западной формы изз окр. Томска.

Нахожленіе восточной разновидности въ изсльдуемом районт, представляетъ несомньнно интересъ, таґъ какъ она пока бы.та изв屯стна лишь изъ Восточной Сибири и тиюок описанія послужи.лъ эк:з. изъ окрестностей Красноярска, находяційся въ моей частной коллекцин, подарокъ М. Е. $К$ иборта. Экземпляры западной формы встрбчаютея довольно часто въ окр. Тонска. Лри сравненіи тыхт и другихт съ тнпоя, не можетт быть и сомнынія въ томъ, что формы эти не тождественны. Шривожу измьренія добытыхъ на правомт, берегу Иртына экземпляровъ:

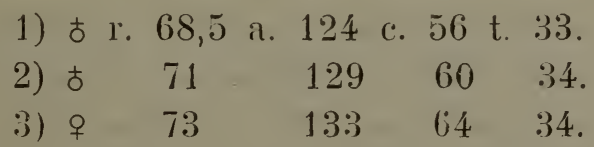

С. А. Бутурлинь. (стр. 55) уиазываеть слылуюшіе размылы варіацій в'ь пластических'ь признакахъ бекасал: крыло-120-140 мм., хвость-56-70 ми., цлювъ $-59-76$ мм, плюсна 29-34 мм. Сравнивая размбры добытыхъ экземпляровъ, мы находимь, "то бни не превышаютъ указанныхъ предъловъ. Доо̆ытая самка крупнъе самцовъ, что подиерждаетъ указаніе въ новомъ изданіи „Nаuтапи'а“. 


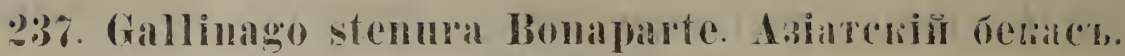

Әтоть кулик', свойственный Босточний (нопии, хотя и ириводитея А. Морозовымъ (стр. 4) для Омска, но лиши, какъ „nomen nudim"! Намъ вт, степяхт. нашего прая не попадаля,

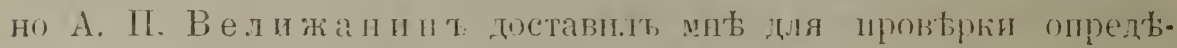
лепія экз. этого вида шзъ подъ Барнаула, убитый имъ 10-го августа

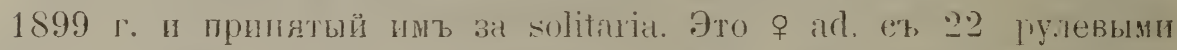
и по моему мныніп несомивнно -tenura. IПесть рулевыхт съ каждой стороны очен узги, ширина ихи, менье 2,5 м., при этомь оии кь вершин сьуживаютя. Хвость этого :қземп. олень

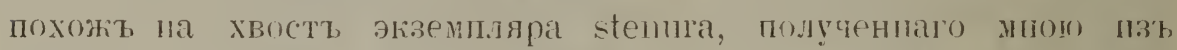
Маріинскаго утзда Томской гую́.

\section{gass. Gallinago megala swinhoe. Jrgenoü ayae.n.}

$$
\text { (=heterocerca Cab) ) }
$$

Надъ небольшимз озеромъ въ Кулундинскомъ бору около с. Вылкова я слышаль и видблт 17-го іюня 1902 года хорошо извьстнсе мив по Томску токованіе льсного дупеля. Изъ другихъ мъстностей посьщенныхъ нами стеней свъдьній " нахожденіи этой птицы не имбется. Литературныхъ указаній о нахождепіи этого кулика въ степной части Тонскаго юрая я найти не могъ. Въ коллегціяхь эвземплярозт пзљ, интересующей насъ мыстности такзіе не пмьется. С. А. Бутурлинъ (Булики II стр 77) со. обшаетт, что этоть видъ иногда валетаеть къ Омеку, пткуца экз. вт, музељ Академіи Наукљ.

\section{Gallinágo gallinula Limn. Tapmuent.}

П. А. Шастовскій сообщаеть мнђ, что нашель в’ ппр. ст.

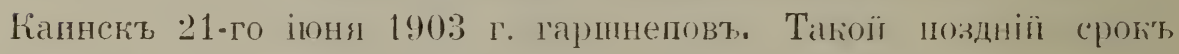
безъ всякаго сомпьнія позволяетъ причислить гаршнеповъ к”ь гнъздящимся птицамъ Барабинской степи, что предетизляетъ иъкоторый питерег'ь. таћъ какъ южная граница гнћздовья этого кулика еще далеко невыяснена. Въ Кулундинской степи мы гаршнеповъ не находили, равнымъ образомъ ихъ не добыля и степная әкспедиція проф. Н. Ө. Кащенио 1900 г. Изъ окрестностей Барнаула вт, моей коллекпіи имъется весенній экземплярт, измћренія котораго привожу ниже. Гаршнепт, вћроятио, на пролетахт, 


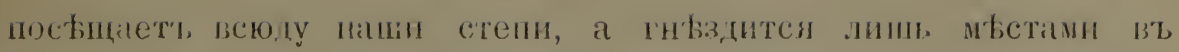
Барабъ. Finsch (стр. 254) получнль птт, И. Я. Словцова (ср. 1897 стр. 157) экземп. изт, окр. Омска; его спутникь $A$. Brehm уо̆лт, гірпнепа близт, Семипалатинска въ апркль. Но А. Mорозову (стр 4.) „встрьчается часто, но не въ полыпот количествђ, а таще одиночными экзғмплярами поль Омскомъ. В. Н. Плот тиков'ь совсьвт, не наблюдаль гаршненовт, на Иртышь, равным', образомъ и Слов цовт ничего не говорит', о наховденія ихт подь Тюменью.

Экземплярь моеӥ ко.тепціи:

1) ad. г. Барнауль 21,1r 99 r. 40,5 a. 113 c. 56 t. 24. 


\section{LONGIPENNES. (Длиннокрылыя).}

\section{Ð40. Hydrochelidon nigra Limn. Kpamia repнag.}

Мұстн. назв.: „серпокъ“ (цер. Чистовзерская).

Черная крачка вт, изсльдуемыхъ частяхт Томскаго грал пстры-

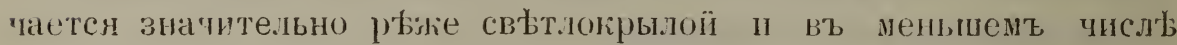
огобей. Въ Барабинской степи я находилъ ее иа одном' озерь

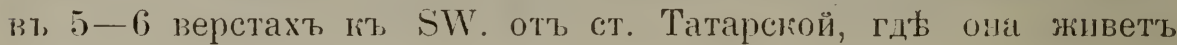
вмысть со сльдующим' видомъ. На Иртышь подт Омекомь я замьтнлъ черныхт, крачекъ 24-го іюня 1899 г. Въ Кулундинской стеши мы находили эту крачку близъ дер. Плотниковой и Чистоозерской; въ меей частной коллекціи два экземпляра этого вида изъ окр. г. Барнаула. Экспедиція проф. Н. Ө. К а ш е н ко доставила вт, нашт музей экземиляръ изъ приалтайскихъ степей (с. Убинское).

Экземпляры коллекцій:

1) ad. ст. Татарская $17 /$ v 99 l. 29 a. 206 с. 84 t. 16 ши.

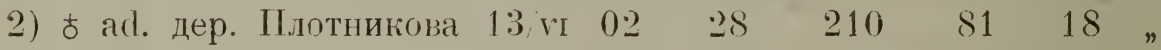
3) ᄒ аd. г. Њарнаулт $\quad 30 / \mathrm{r} \quad 99 \quad 28 \quad 218 \quad 84 \quad 17$ " 4 ) јur. " 5) ᄒ ad. с. Убйнское 26 гі $00 \quad 28 \quad 217 \quad 85,5 \quad 15,5$ ”

Отъ П. А. Ш астовскаго я получилъ кладку этой крачки, взятую 19 г 1907 близъ ст. Каинскъ, состояцую изъ трехъ яицъ.

Размғры и вђсъ ихъ:

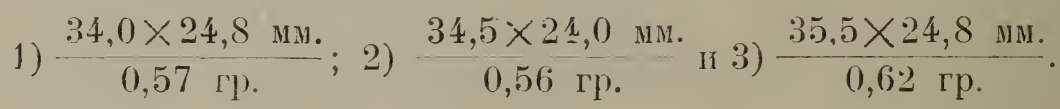

По А. Морозову (стр. 2) эта крачка обычная форма по Иртышу и ближайшиъ къ нему озєрамъ. В. Н. Гллотни ков ъ не приводитъ этото вида. Экспедиціею П. Г. Иг н а тов а этотъ видъ найденъ въ Акмолинскомь и Атбасарскомъ уъздахъ (В. Біан ки стр. 8), а И. С.овцовымъ въ Коктетавскомъ (стр. 161). O Fin sch (стр. 28(1) наблюдаль әтотъ вндъ на Иртышђ и видълт, экз. вт 
коллекціи И. Я. С ловцора пзъ окр. Олска. М. Д. Рузски и эта кратюа найдена на прысныхт, п солоноватых', пзерахт, южной полосы Тобольской гут. (стр. 4). Пп Слов цову (стр. 226)

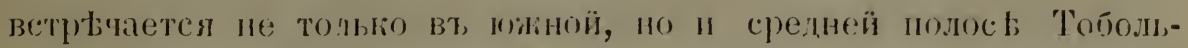

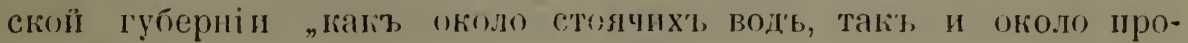
точных'ь".

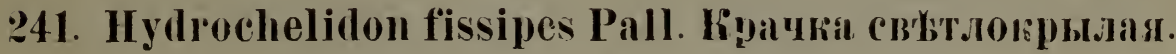

$$
\text { (:-leucoptera Schinz). }
$$

Мкстн. назв : „серпокт,“ (дер. Чнгтовзерская).

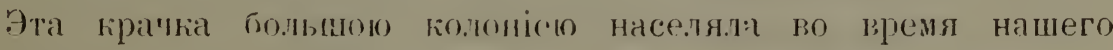
преб́ыванія на ст. Татарской густо пороспее қамынами озеро близь, селенія и нькоторын болье отлаленныя озера около этой станціи. По проф). М. А. М ензби ру (Птицы Россіи стр. 170)

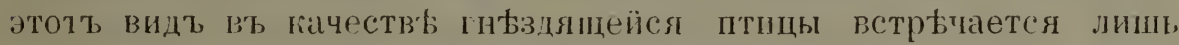
"по кжной окраннь Сибири“, так' тто нахозіденіе этой грачки въ Барабинский степи представляетъ ићкоторый интересъ. Между

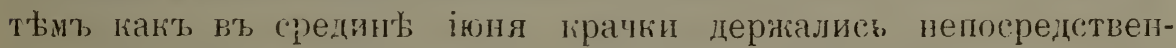
но нацт, озеромъ или близ'ь єео берега, въ конць іюня онь стайкани вт, 20 штук'ь нерьдко появлялись и на зналительном'ь разстонніи оть воды, гдћ усердно пресльдовали наськомыхь изъ первскрылыхт (Aeschna sp. и Libellula sp.). Hinz приходилось ихь наб́пюцать около березовой рощцци, на пашняхт, й въ

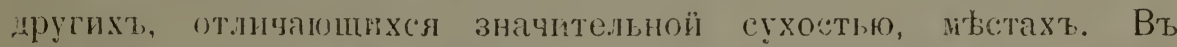
болиной, поридниому, друћо̆ и полном' согласіи (Һ әтими крачками живутт малыя чайки (Larus minutus Pall.). Встревоженныя выстрблопъ крати прилетакть иногда на значительние разстояніе полюо́лытствовать, что случилось. Среди такихь стаекъ, летьвиихь на выстрьль, я почти всегда заньчль, нұ́(:кıлько малыхь, чіекъ. Крикь грачекъ, непереданный въ упомянутоми, сочиненіи проф. Менз и и а, можно передать словами „кря“, ,кря

Въ Кулундинской степи эту крачку мы почти повсемъстно находили въ значительномъ числт особей на стеиныхъ озерахъ (цер. Плотникова, с. Вылково, ц. Чистоозерская и др.). Въ дер. Плотниковой я получить два насиженныхъ яйца этой крачки 15-го іюня 1902 года. 


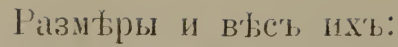

$$
\text { 1) } \frac{35,0 \times 25,0 \text { ми. }}{0,58 \text { гр. } 2 \text { и }} \frac{34,0 \times 25.0 \mathrm{mм.}}{n, 61 \text { гр. }} \text {. }
$$

Затђив весною 1907 г. я получилъ изъ окрестностей стан. Каинскъ кіладку изъ двухт лицъ этой кратики, взятую 19-го мая II. А. III а с тов с ки и в.

Ихт, изиьренія:

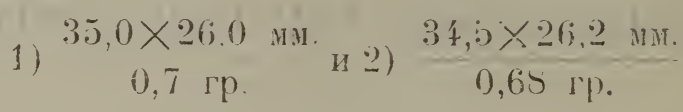

Экпедиціею проф. Н. Ө. Ка шепко добыть экземил. әтой крачки на озерђ олизъ с. Јокоть вт приалтайскихъ степяхъ. Въ моей коллекціи имыются экз. изъ окр. Бариаула.

Экземпляры коллекцій:

1) む ad. ст. Татарская $17 /$ vi 99 r. 23 a. 215 c. 74 t. ? чуч.

2) $q$

3) q

4) +

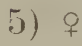

6)

i) ㅇ

8) ㅇ

9)

10)

11) $\delta$

12) ᄒ

13) 우

14)

15)

16) $t$

17) $\delta$

16 гा $99 \quad 27 \quad 220 \quad 78,5 \quad 21$ шк. 17 ॥ $99 \quad 24,5 \quad 214 \quad 71 \quad 19$. 16.I 99 2.,5 $204 \quad 76 \quad 20 \%$ " 19 v1 $99 \quad 23 \quad 203 \quad 69 \quad 19,5$.

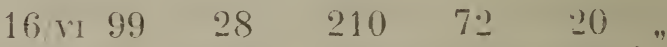
16 ำ $99.25 \quad 20207 \quad 20$ ” $16 \times 199 \quad 23,500 \quad 65 \quad 20$ " 17. ㄷ $9925 \quad 212 \quad 77 \quad 20$ " 17 以 $9926 \quad 214 \quad 74 \quad 20, \bar{*}$ " 17 I $99 \quad 25 \quad 208 \quad 68 \quad 20 \quad$ n

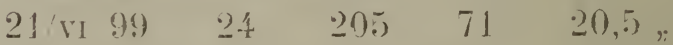
$\begin{array}{lllllll}21 & 149 & 25 & 213 & 75,5 & 20\end{array}$

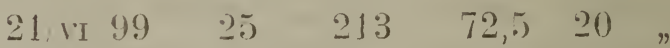
$26 /$ vi $9924 \quad 215 \quad 74 \quad 20$ ” $26 /$ r $99 \quad 24 \quad 214 \quad 76 \quad 20,5 \%$ 26 พr $9926212 \quad 65,5 \quad 20,5$,

Изъ этихъ экз. пишь у очень немногихт голова и шея не обнаруживають начала линьи, у большинства же появились въ большей или меньшей степени на этихъ ұастяхъ бьлыя перыпи.

18) t ad. с. Вылково 17/ ri 02 r. 28 а. 208 с. 75 t. 20 шк.

19) sex? semiad. ,

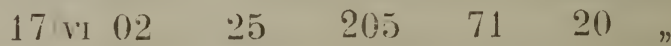

20) t ad. с. Локоть 9 ז $00 \quad 25 \quad 207 \quad 74 \quad 20,5 \%$

21) г. Барнаулт 2 ห $0122519972 \quad 21,5$ 


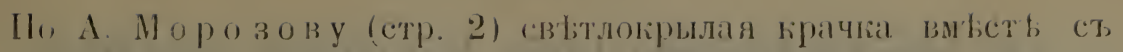
чериой обылиня формы подь Омскомъ. Нриводится В. Н. Плот-

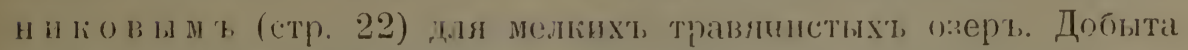

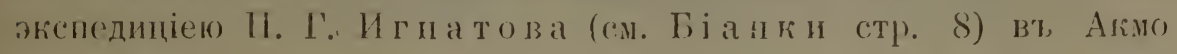
.иисколт, 11 Aти́a (комт. (стр. 161). Fi

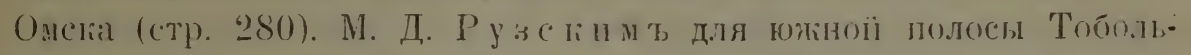
ской губ. пе приводитяя, оттуда пе уноминается и И. Я. С.лов-

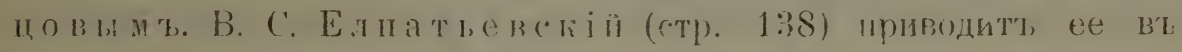

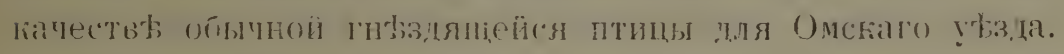

\section{- Sterna (Gelorhelidon) anglica Mont. hiparia repro- IInciass.}

Экспедиціею ПІ. Г. Игиатпва эта қратка пайдена па озер.

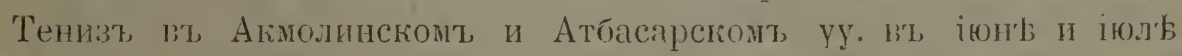

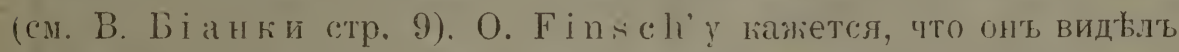
на Черном Иртышы близл, Норъ-Зайсана большія колоніи именно әтого вида. О нахоліденіи этой крачки в'є предњлахт напего гірая пока ничего нензвыстно.

\section{Sterna (Iy ydroprogne) caspia Pall. Yerpaba.}

По Палла су (стр. 333) чеграва „сорiosissima in maximis camporum Rarahensium lacubus". Позднйыніе изствдователи этой птицы однако не находятъ, в’ таком'b количеств'b, “ в'т Бараоинской сте!и чегравы посль П алла са нгіто не находияъ. По А.

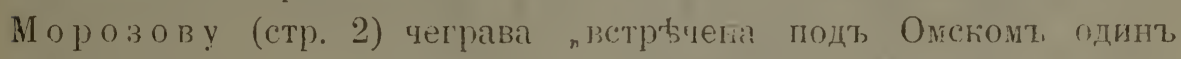

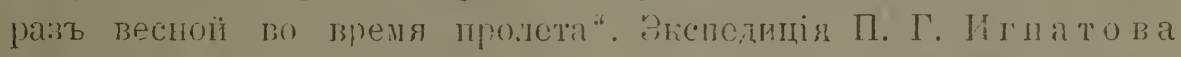
(см. Біан ии стр. 9) добыта әту итицу вт, двухт экз. вт, іюльи

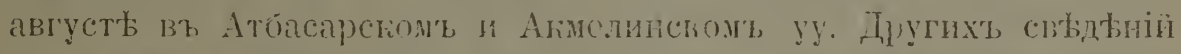
въ моем's распоряженіи н'ът', равнымъ образомь отсутствуютъ эгіземпляры в' нашихъ коллекціях'ъ.

\section{- Sterna fluviatilis tibetma Samnd. Naptumsa tróer- rкия.}

B. Б і ан к и относить мартышект спора II. I. Иглатов а изъ Акмо.инскаго и Атбасарстаго уу. къ этому поцвиду (етр.9). Сюда, вЈроятно, относятся и найденныя вт, Кикчетавскомь у. И. С по в цовым т, (стр. 161) мартынки. 


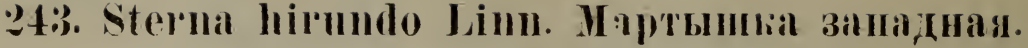

\author{
(= fluviatilis Naum.)
}

Мьстн. назв.: "чериоголовкал" (д. Чистоозерскаи).

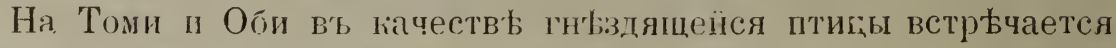

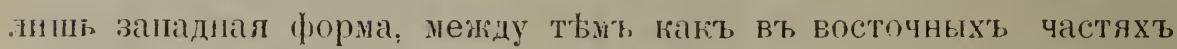
нашег края, по Чульму, мнюю найдена и восточная форма St. longipemnis Nordm. Въ степной части нашего грая пока найдена липь заладная фо!)ма. доставленная въь нашъ музей всъми эгспедиціями, работавниии какъ в, Барабинской и Кулундинской степяхъ, такъ и в’ь приалтайскихт. Вт Бараб'b эта гіратка найдена на озерь Чаны, Вь огр. г. Каинскь, близт ст. Коченево и Татарской, близъ Омска, на р. Оми близъ ст. Калачинской. Вь пищеводы убитыхъ найдены хвостовыя половины гольянов' (Phoxinus sp.). Мартышки, повидимому, пткусывағть головы пойманых'ь рыбъ и не проглатывають ихт. IT. А. IU астовскі й доставиль мны двђ кладки әтой крачпи изт, Raпнскано у., найденныя имъ $16 / \mathrm{r}$ 0.). Въ каждомт гнбздт; паходнлось по деа совершенно ненасизенныхъ яйца. Одну кладку (А) я передань в’ь оюлогичестуюю коллекцію нашего музея. Размьры (въ мм.) и въсь скорлупы (вт, гр.):
A 1) $\frac{40,2 \times 30.0}{1,02}$
2)
$38,5 \times 29.0$
0,94
B :3) $\frac{43,0 \times 30,0}{1.06}$
4)
$\frac{43,5 \times 29,5}{1,09}$

Въ Кулундинскои степи мартышка во мнолествы летает, надъ пзерами близ, дер. Плотнипвой. Дильныйшія мъстонахож-

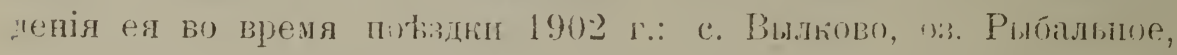
дер. Чистоозерская и т. д. до стан. Семиярской на Иртышћ. Близъ Барнаула встрбчается. Экспедиція проф. Н. Ө. Кащенко добыла мартышку близъ стин. ПІульба п дер. Саушки.

Экземпляры коллекцій:

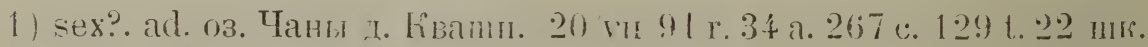

2) sex? ad. $\quad$ ". $\quad 19191191 \quad 34 \quad 275 \quad 127 \quad 21$ чуч.

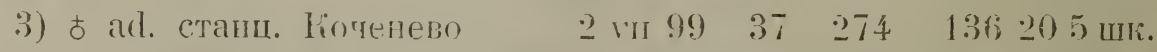

4) 9 ad.

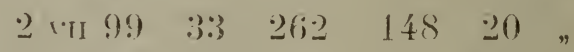

5) sex. ad. " Канискт

6) о ad. дер. Саушка

30 rII $99 \quad 3: 3 \quad 250 \quad 1: 37 \quad 19,5 \quad$

7) ๘ аd. пог. Шуульба

$\begin{array}{lllllll}5 & 00 & 35.5 & 276 & 139 & 20 & 0\end{array}$

21 V $0037 \quad 273 \quad 14420,5$ ", 
8) d. пос. Шульба

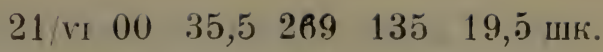

9) $\&$ ad. $n$,

$23 /$ VI $00 \quad 35 \quad 274 \quad 154 \quad 19,5 \quad$ ”

10) $\&$ ad. ст. Семиярская

$22 /$ vII $02 \quad 34 \quad 270 \quad 131 \quad 19 \quad$,

Гоо И. Словцову (стр. 161) и А. Морозову (стр. 2) эта мартышка подъ Омскомъ „встрбчается, но не часто “. По В. Н. Пл о тн и ко в у (стр. 22) она „очень многочисленна“. Изъ Тобольской губ. извъстна М. Д. Рузскому (стр. 23, 24 и 26) и И. Я. Словцов у (стр. 226).

\section{Steruula minuta Limn. Iipaчka nasas.}

Сборы наши въ степяхъ нашего края не подтвердили словъ П ал л а с а (стр. 336) „in campis barabensibus frequens". Въ университетскую коллекцію поступили лишь сборы проф. Н. Ө. К а щ е н ко изъ приалтайскихъ степей, гдъ въ окр. пос. Шульба было собрано 4 экз. Во время поъздки по Кулундинской степи намъ эта крачка ни разу не попадалась и лишь на Иртышь близъ стан, Семиярской я 22-го іюля 1902 г. видєль эту крачку на слишком' большомъ разстояніи, такъ что птица осталась не добытой. Изъ с. Тулинскаго на Оби и изъ окр. Барнаула я гріобрьлъ два экземпляра, измьренія которыхъ даю ниже.

Экземпляры коллекцій:

1) ㅇ пос. Шульба 22, v 00 r. 30 а. 170 c. 71 t. 15,5 шк.

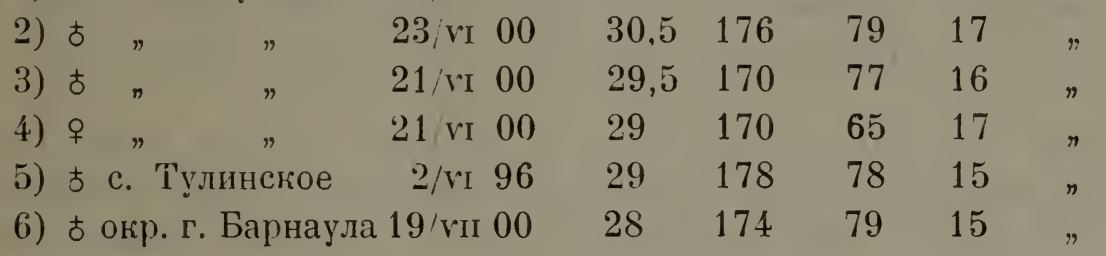

По А. Моғозову (стр. 2) подъ Омскомъ бываетъ пролетомъ. ПІо В. Н. П ло т н и к в у (стр. 22) въ окр. поселка Ямышевскаго на Иртышь многочисленна. Экспедиція П. Г. Игнатов а (Біанки стр. 9) добыла нбсколько экз. въ Акмолинскомъ и Атбасар. скомъ увздахъ. O. F in s c h совсћмъ не упоминаетъ объ этой крачкъ, найденной М. Д. Р у з ски м з (стр. 24) въ изсльдованной имъ южной полось Тобольской губ. Словцовымъ не упоминается для Тюмени. 


\section{Larus (Hydrocoleus) minutus Pall. Yaй мa мaя.}

Эта красивая чайка мыстами очень обыкновенна въ Барабинской степи. Мы находили ее въ окр. ст. Коченево, ст. Татарской, станц. Калачинской на Оми. Во время степной әкспедиціи проф). Кащенко 1900 г. добыта въ с. Локоть. Во время пођздокъ по Оби на пароходъ олъ Томска до Барнаула эта чайка ни разу не наблюдалась ниже жельзнодорожнаго моста. Но около с. Камень она. встрђчается уже довольно часто. Въ Кулундинской степи малая чайка по озерамъ очень обыкновенна (дер. Плотникова, Чистоозерская). Въ моей коллекшіи экз. изъ окр. Барнаула.

Экземпляры коллекцій:

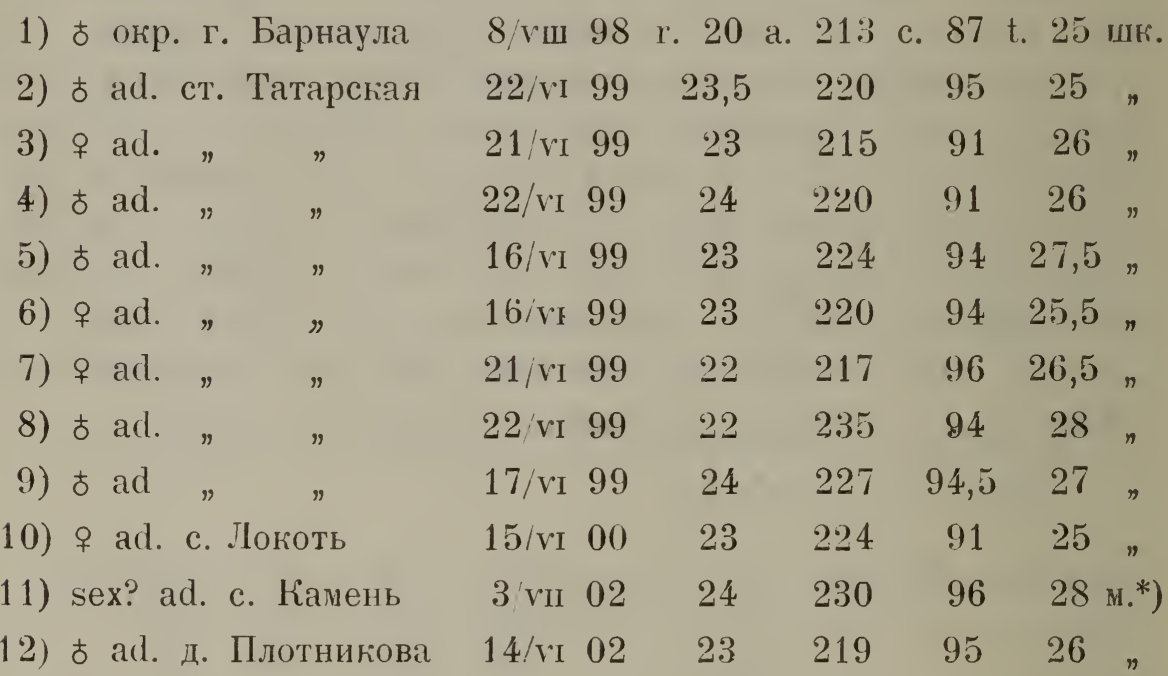

Отъ П. А. Ш астов скаго я получиль восемь яицъ этой чайки изъ Барабы (окрестности ст. Каинскъ), гдђ она гнбздится во множествъ. Яйца изъ разныхъ гнъздъ взяты около 20-го мая 1907 г. По окраскъ онъ значительно варіируютъ. Основной фонъ ихъ темно-зєленый, бльдно-зеленый, оливковый, буровато-зеленый, бурый, желтовато-бурый или бльдно-охристый. Пятна также варінрують и по размбрамъ, по расположенію и по интенсивности темнаго цвъта, который представляетъ всђ переходы отъ пепельнс-съраго до чернаго и темно-бураго. 
Размћры и въсть этихъ яицт:

1) $\frac{41,5 \times 30,0 \text { мм. }}{0,95 \text { гр. }}: \frac{39,5 \times 30.5 \text { мм. }}{0,98 \text { гр. }} ; 3 \frac{41,0 \times 31,0 \text { мм. }}{1,16 \text { гр. }}$

4)

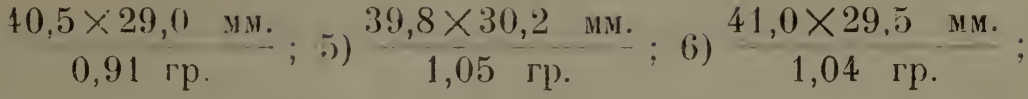

$$
\begin{aligned}
& \text { 7) } \left.\frac{40,0 \times 29,5 \text { м... }}{1,05 \text { гр. }} \text {; } 8\right) \frac{41,5 \times 30,5 \text { мм. }}{1,10 \text { гр. }}
\end{aligned}
$$

Co мнбніемғ ц-ра О. Finsch (стр. 276), что малая чайка „wie überall, auch in Sibirien selten“ врядъ-ли можно согласиться, если принять во вниманіе соорранный нами матеріалъ и литературныя данныл. А. Морозов ъ (стр. 2) часто находилъ ее подъ Омскомъ весной и считаетъ ее гнъздящейся по Оми птицей. В. Н. П л о тн иков ъ (стр. 22) въ окр. поселка Ямышевскаго $3 \cdot 4$ раза наблюдаль ее на песчаныхъ отмеляхъ оз. Пръснаго. Въ Акмолинскомъ и Атбасарскомъ уу. найдена П. Г. И г н ато вы м (стр. 9). Въ Тобольской губ. найдена М. Д. Р у з с к и м з (стр. 23 и 24) и И. Я. С. о вцов н в (стр. 226) в’ качеств новенной птицы.

\section{Larus (ChroicocephaIus) ridibundus Linn. Чaйка обыиновецная.}

Чайка обыкновенная широко распространена въ степной части нашего края. Въ Барабинской степи она найдена во время пођздокт 1891 и 1899 г. на сльдующихъ озерахъ: оз. Чаны, оз. Кута, оз. Ураково близъ ст. Убинской, оз. Убинское, мелкія овера близъ ст. Татарской. П. А. ІІ а с т о в ск і й доставилъ мнъ 8 яицъ изъ разныхъ гнбздъ этой чайки, взятыхъ имъ $15 \cdot$ го мая 1905 г. близъ ст. Каинскъ. Въ гньздахъ находились неполныя кладки (1-3 яицъ), размбьры и въсъ которыхъ:

$$
\begin{aligned}
& \text { 1) } \left.\frac{52,5 \times 36,2 \text { мм. }}{2,21 \text { гр. }} \text {; 2) } \frac{52,0 \times 36,0 \text { мм. }}{2,14 \text { гр. }} \text {; } 3\right) \frac{54,0 \times 37,2 \text { мм. }}{2,35 \text { гр. }} \\
& \text { 4) } \left.\left.\frac{57,0 \times 37,2 \text { мм. }}{2,32 \text { гр. }} \text {; } 5\right) \frac{53,0 \times 38,0 \text { мм. }}{2,35 \text { гр. }} ; 6\right) \begin{array}{c}
52,8 \times 36,8 \text { мм. } \\
2,19 \text { гр. }
\end{array} \\
& \text { 7) } \frac{52,5 \times 35,2 \text { мм. }}{2,23 \text { гр. }} \text {; } 8 \frac{53,8 \times 38,0 \text { мм. }}{2,30 \text { гр. }}
\end{aligned}
$$


Два первыхъ яйца мною переданы В' зоол. музей нашего университета. Во время поъзлокъ по Оби эта чайка ие особенно часто наблюдалась нами. Въ дневникь повьзки она отмбчена только у с. Спирина и Тулинскаго, Барнаульскаго у. Гораздо чаще она наблюдалась по степным' озерамъ въ Кулундинской степи, напр. близъ дер. Плотниковой, гды этотъ видъ вмћсть съ сородичами очень способствуетъ оживленію ландшафта. Неоднократно эта чайка наблюдалась близъ д. Чистоозерской, на озер. Маралда (Павлодарск. у.) и ио Иртышу сь парохода огъ стан. Семиярской до Омска. Степною экспедиціею проф. Н. Ө. К а щ енко 1900 г. әтотъ видъ также .дибытъ

Яйца всђхъ чаекъ и другихъ водяныхъ птицъ усердно собираются и употребляются въ пищу. Въ окр. д. Чистпозерской ихъ. собираютъ, как'ь мнб сопбщали, сотнямх и тысячами. Давно бы сльдовало принять мбры противъ такого хищническаго истребленія пернатыхъ.

Экземпляры коллекцій:

1) sex. ?јuv. оз. Чаны д. Квашнина 19 vi 91 r. 30 а. 280 с. 116 t. 43 шк. 2) sex.? ad. оз. Кута ¿. Таскаево 25 vi $91 \quad 36 \quad 30513040,5$ \# 3) sex.? juv. " \# $25 /$ viI $91 \quad 31 \quad 310 \quad 117 \quad 40$ q. 4) sex.? juv. оз. Убинск. с. Карганъ31/vi 9129265112 38,5 ” 5) ᄒ ad. $\quad$ ст. Убинская $10 /$ гі $99 \quad 36 \quad 313 \quad 125 \quad 46$ шк 6) 우 ad. ст. Татарская 15/ri $99 \quad 33 \quad 305 \quad 122 \quad 43$, 7) ᄒ аd. дер. Саушка $31 / \mathrm{r} \quad 00 \quad 34 \quad 312 \quad 117 \quad 43$ ” 8) ᄒ ad. дер. Плотникова 12/vi $02 \quad 36 \quad 32312245$ ”

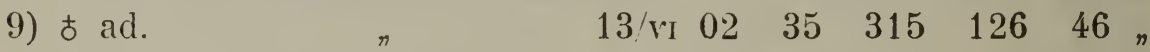

Литературныя данныя всъ свндътельствуютъ о повсемъстномъ нахожденіи этой чайки. Вниманія заслуживдетъ сообщеніе В. Н. П лотнико ва (стр. 21), что эта чайка „во время саранчи уничтожаеть ее въ очень значительномъ количествъ“.

\section{4\%. Larus gelastes Licht. Чайка тонкоклювая.}

$$
\text { (= Larus tenuirustris Temm.) }
$$

Эта чайка лишь случайно залетаетъ до Иртыша. По свидътельству В. Н. Плот ников а (стр. 21) „попадается, но очень рбдко“. Ему удалось достать только одинъ экземпляръ. По А́. 
Морозову (стр. 2) „морской голубокъ рбдкая форма“. Другихъ указаній па нахождепіе этой чайки ньтт, равпымъ образомъ, нбтъ и экз. въ нашихъ коллекціяхъ.

\section{Larus ichtyä̈tos Pall. Уepnorojobuй хохоту⿰丿.}

Эта чайка, характерная для фаўны Каспійскаго мори, зале. таетъ иногда въ нашъ край. По свидттельству В. Н. Плотникова (стр 21) она имъ наблюдалась близъ пос. Ямышевскаго тр: раза в’ь марть 1892 г., вт, 1893 и въ 1895 г. Вт, желудк'ь уб́итаго имъ экз. этого хищника оказались мышь и трясогузка. Finsch наблюдалъ эту чайку значительно южнъе, на Сасык.Ала-кулғ, Нор-Зайсанъ и въ др. м. (стр. 274). Этимъ и ограничиваютея всь свђдђнія о нахожденіи этого вида въ изслђдуемой мЂстности. Въ коллекціяхъ экземпляровъ. ньтъ.

\section{Larus fuscrus Linn. Risyma.}

И. Я. Словцовъ (189- стр. 161) сообщаетъ объ экз., убитомъ 23-го іюня 1876 г. близт Омска. По свидытельству А. M о розова (стр. 2) эта чайка „на пролеть несомньнно встрђчается “. Экз. убиты въ Петрспавловскомъ у. и одинъ изъ нихъ находится В’ь музеђ Зап. Сиб. Отдьла И. Р. Г. О. Въ нашихъ коллекпіяхъ экз. изъ степной части нашего края ньтъ.

\section{Larus affinis Reinh. Хохотунья сибирккая.}

Приводится В. С. Елп а т ь е в ск и м з (стр. 137) для Омскаго убзда на основаніи одного экземпляра (не вполнб взрослаго), убитаго $2 /$ เ 1898 г. на кжномъ берегу озера Кызылъ-гакъ. Другихъ указаній н ьтъ.

\section{Larus argentatus cachinnans Pall. Чaйка-хохотунья.}

Мъстн. назв.: „клуша“ (оз. Убинское и дер. Чистоозерская).

По всьмъ болье или менъе обширнымъ озерам'ь степной части нашего края чайка-хэхотунь.я еесьма обыкновенна. Въ коллекціи имъются экзенпляры съ озєръ Сартланъ, Убинское, Чаны. Въ Кулундинсгой степи маленькія озера не служатъ мьстопребывяніемъ чайки-хохотуньи. Мы нахюдили ее лишь на озерахъ Няшино и Тараторино близา, дер. Плотникивой, и на озерахъ близъ д. 
Чистоозерской. На Оби въ Барнаульскомъ округъ эта чайка встрђчается.

Экземпляры коллекцій:

1) sex.? ad. оз. Сартланъ. 24.п 91 г. 58 а. 445 с. 165 t. 67 ч. 2) „ јuv. Барабинскія озера іюль $9151 \quad 410 \quad 15868$. $3)$ „ad. оз. Сартлан'ъ 26 гі $91 \quad 54 \quad 405 \quad 170 \quad 64 \amalg$. 4) sex?juv. оз. Чаны

5) sex? semiad. 20 vir $9153,5 \quad 425 \quad 168 \quad 71$, 6) sex?.juv. 0з. Сартлан ъ $20 /$ रा $91 \quad 52402 \quad 17164$ n 7) sex? juv. " 24: VII $9148380 \quad 16364,5$, 8) sex? ad. оз. Чаны 24 vil $9153 \quad 404 \quad 160 \quad 66$ " 9) sex? ad. „ Сартлан'ь 19 rII $9153 \quad 403 \quad 16061,5$. 10) sex? ad. Барабинскія озера ію.ль $91 \quad 55 \quad 415016503$ ч. 11) ᄒ ad. озеро Убинское $\quad 10$ ю $99 \quad 57 \quad 435 \quad 176 \quad 69$ ш. 12) ᄒ ad. цер. Чистоозерская 24. 0261 (взятъ.лишь черепъ).

А. Морозов (стр. 1), упоминая „Larus argentatus Brünn.". сообшаеэъ, что подъ Омскомъ она встрьчается рьдко. O Larus cachinnans Pall. онь ничего не говорить, и у меня явллется сомньніе въ правильности его ппредьленія. В. Н. Плотниковъ для окр. поселка Ямышевскаго приводитъ какь сасhinnans Pall, такъ и argentatus Brünn. (стр. 22), причемъ гервый ему былъ доставленъ лишь одинь разъ. М. Р узскій для южной полосы Тобольской губ. приводитт, лишь Larus cachinnans (стр. 24); равнымъ образомъ И. Я. Сл овщовъ, (стр. 225) приволить одну лишь Larus cachinnans Pall. какт, пролетную оголо Тюмени весною.

\section{- Larus argentatus Brinn. Iăha cepeбpurrag.}

Экземпляры изъ Барабинской степи, поставленные проф. М. A. M ензби ру, имъ были опредъ̆лены за cachinnans. Изъ всьхъ извъстныхъ мнђ авторовъ одинт, лишь, В. Н. Плотников ъ (стр. 22) утвержзцаетъ, что чайка серебристая въ окр. пос. Ямышевскаго „водится въ зЕачительномъ количествъ, придерживаясь преимущественно Иртыша и болышихт, прбсныхъ озерт.". Для Акмолинской области указывается И. С ло в ц в ы ъ (стр. 161), но экземпляы, добытые экспедиціею П. Г. Иг натов д, опредылены В. Л. Біанки (стр. 10) какт cachinnans Pall. 


\section{Larus canus niveus Pall. Чайна спзия сибирская.}

Мћстн. назв.: „чайга“ (оз. Убинское): „мартынъ “ (лер. Нижній Кучукъ).

Эта чайка отень обыкновенна въ Барабинской степи, гдь она найдена въ сльдующихъ мъстахъ: оз. Чаны, оз. Сартланъ, озеро Убинское, оз. Ураково близъ ст. Убинской. Около Убинскаго оз. стайка изъ $\&$ особей этихъ красивыхъ въ брачномъ опереніи птицъ расхаживала 9-го іюня 99 г. по только-что вспаханному полю. Убитая изъ этой стайки $q$ имћла въ желудкь исключительно остатки насғкомыхъ, среди кпторыхъ мозно было узнать Carabus sp. и Libellula sp. Гнъзда чаекъ, по словамъ рыбаковъ, на этихэ, озерахъ усердно отыскиваются и яицъ уничтожается изрядное количество. Въ Кулундинской степи әту чайку мы находили во многихъ мъстахю, напр. близъ дер. Плотниковой, Чистоозерской, по р. Степному Кучуку и у его устья, на пз. Маралда (Павлодарскаго уђзда) и по Иртышу между Павлодаромь и стан. Семиярской, Въ окр. г. Барнаула эта чайка гнъздитея. Экспедиція шроф. Ка ще н ко 1900 г. нашла ее близъ с. Локоть.

Экземпляры коллекцій:

1) sex.? juv. оз. Сартл. с. Таскаево $24 /$ mi 91 r. 42 a. 365 с. 150 t. 57 ч. 2) sex? juv. " " $\quad 25 /$ ril $91 \quad 37 \quad 363 \quad 137 \quad 53$ ш. 3) sex?juv. пз. Чаны д. Квашнина $21 /$ vi $91 \quad 34 \quad 305 \quad 127 \quad 53$ " 4) sex? ad. оз. Уо́инское $30 /$ ri $91 \quad 36 \quad 365$ 103(!)50 " 5) sex? juv. " $\quad 16$ ril $91 \quad 37 \quad 370 \quad 148 \quad 58$, 6) sex? juv. $\quad$ с. Карганъ $30 /$ vi $91 \quad 36 \quad 385 \quad$ ? 54 ч.

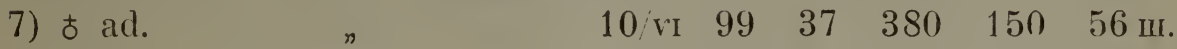

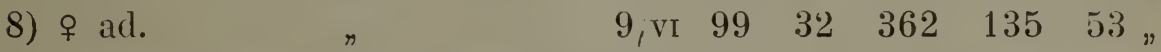

Упоминаемаго у проф. М енз бира (IIтицы Россіи стр. 140) бълаго зеркальца близъ вершины третьяlо махового у экз. 스 7 и $8 \mathrm{H}$ 'bтr.

9) ᄒ ad. с. Локоть 8/vi $00 \quad 44 \quad 387 \quad 150 \quad 59$ ш. 10) баd. устье р. Степного Кучука $6 /$ vir $02 \quad 40,5385 \quad 157 \quad 56$ ”

Сизая чайка подъ Омскомъ по И. С ловц ову (стр. 161) и А. М орозову (стр. 1) встрбчается рвдко. По В. Н. Плотников у (стр. 22) по Иртышу „довольно обыкновенна“. Экспедиціею ПІ. Г. Иг н а т о в а (стр. 10 Біанки) найдена въ Кокчетав. 
скомъ, Акмолинскомъ и Атбасарскомъ уу. Вь первомъ изъ нихъ найдена и Слов ц о вым ъ. Въ Тобольской губ. по М. Рузскому (стр. 23, 24 и 26) и И. Я. Слов п о в у (стр. 225) гньздуетъ. По В. С. Е л п а ть ев скому (стр. 136) представляетъ наиболье обыкновенный видъ чайки, массами населяющій соленыя озера Омскаго уьзда.

\section{- Sterorarius pomatorhinus Temm. Monopunk ryeguili.}

По И. Я. С ло в ц о в у (стр. 225) „средній поморникъ убитъ на Андреевскомъ озерь въ половинь августа 1890 г.“. Другихъ свбдъній нб̆тъ.

\section{- Stercorarius crepidatus Gmel. Ionopuna hopotio- хвостый.}

По И. Я. Словцову (стр. 225) „этотъ видъ поморника убить около Тюмени въ мађ мъсяц 1888 г., в屯роятни на пролеть'. Другихъ свьдъній нбтъ. 
XI. SIEGANOPODES. (Iеликановня).

\section{5is. Phalacrocopax carbo Linn. Vaкоaн; больной} (иориорания).

Bь liулундинской степи мпћ в’ъ дер. Чистопзерской изъ разспросовъ мъстныхъ жителей, преимущественно стараго опытнаго охотника Н. Е. Ильиных ъ, удалось узнать, что на оз. Бак.яаньемъ еще до сихъ поръ не перевелись бакланы, хотя встрбчаются въ значительно меньшемъ противъ прежняго количествъ. Самому мнб бакланы въ степной части нашего края нигдњ не попадались. На Иртышђ около Павлодара по разсказам'ъ также встрбчаются бакланы. O. Finsch (стр. 280) сообщаетъ, чтп нЊсколько разъ видълъ большихъ баклановъ на Иртышъ между Бухтармиескомъ и Усть-Каменогорскомъ. Его поразило ихъ ютсутствіе на. Оо̆и. По И. Я. Словцову (стр. 235) „бакланъ быль уб̆итъ около Тюмени 20-го мая 1886 г. на Андреевскомъ оз. въ 20 верст. отъ Тюмени ". М. Д. Руз зкі й во время свпей пођздки въ южной полось Тобольской губ. баклановъ не нашелт. А. Морозов в (стр. 1) считаетъ баклановъ подъ Омскомъ лишь пролетными; свъдъніӥ о гнђздованіи этого вида въ Омскомъ и Петропавловскомъ уу. у этого автора нътъ, но онъ сообщаетъ, что бакланы довольно распространены въ южной пасти Акмолинскаго и Атоласарскаго у'зздовь. Экспедиція П. Г. Иг н ат со ва (см. Б і ан кіи стр. 20) добыла въ Атбасарскомъ у. четыре әкз. На Иртышь бакланы по сообшенію В. Н. Пло тник о в в встрђчаются, посъщая рбку и озера неб́ольшими партіями (стр. 22). $\mathrm{Bz}$ нашихъ коллекціяхъ экземпляровъ нбтъ. По сообщенію П. A. Шасто вска го бакланы встрђчаются на нъькоторыхъ озерахъ близъ Каинска. Проф. Н. Ө. К а ще н ко стрђлялъ по корморану 3-го іюня 1900 г. на Колыванскомъ озерь.

\section{- Phalacrocorax p!gmaeus Pall. Баклант малый.}

Finsch (cтp. 280) сообццаетъ, что видьлъ эту птицу 20 мая (1-го іюня) 1876 г. на Черном'ь Иртышь. Другихъ свЊдъній о 
нахожденіи малаго баклана въ прилегающихъ къ нашему кран мьстностяхъ нь'ть.

\section{- Pelecinus onocrotalus Linn. Рововая баба большая.}

П几 Finsch'y (стр. 280) розовая баба многочисленна на Зайсанъ, но, къ сональнію, не выяснено, какая форма встрђчается тамъ, большая или малая.

\section{Pelecamus onocrotalus reseus Gmel. Малая розовая бa10a.}

Мьстн. назв.: „баба-птица“ (ст. Семиярская).

Экспедиція проф. Н. $\Theta$. К а ш ен ко 1900 года доставила въ наш'ъ музей самку розовой бабы изъ окрестностей с. Јокоть (оз. Першино), убитую 13-го іюня и несомнбнно принадлежапую къ формы roseus Gmel, т. е. къ востотной формъ. Рулевыхъ у этого экземпяяра 22. Разитры, добытые инюю:

$$
\text { r. } 320 \text { a. } 605 \text { c. } 148 \text { t. } 127 \text {. }
$$

Изъ .титературныхэ данныхт, сльдуеть отмћтить измьренія, сообшенныя въ новомъ иаданіи $\mathrm{Naumann'a.} \mathrm{Цифры,} \mathrm{приведен-}$ ныя здысь, въ сравненіи '‘ разиьрами нашего экземпляра, очень малы. Вь станиць Семиярхкой „баба-птица“ казаку В. М. Тр ухину извђетна. Онь считаеть ее для Иртыша лишь пролетной.

\section{- Pelecanus crispus Bruch. Ctpara бaбa.}

По П а ла су (стр. 292) пеликань рьдко появляется иа Барабинскихъ озерахъ. Изъ новьйшихт, изсльдователей одинъ только M. Д. Р узскій (стр. 25) приводить гудряваго пеликана „въ качествь очень рьјкаго письтителя" прђсныхъ и солоноватыхь озеръ южной полосы Тобольской губераіи. И. Словцов ъ (стр. 161) сообщаетъ, что получилъ әтотъ видъ изъ окрестнсстей стан. Прьсногорьковской и что въ Омскомъ и Петропавловскомъ уьздахъ пеликаны дағке не бывають на перелетахъ. Iо его словамъ пеликаны исчезли и въ Кокчетавском уьздњ. 
XII. PYGOPODEs. (Гагаровыя).

\subsection{Colymbus arcticus Linn. Farapa чернозобая.}

Mћcтн. пазв : „гагаучъ“ (озеро Убинское), „ситпевая гагаја“ (ст. Каинскъ) „гагаучъ“ (дер. Плотнигова и с. Ключевое, Барн. у.), „коковикъ“ (дер. Чистопзерская)

Чернпзопая гагара въ качеств' гибздяшейся птицы широко распространена въ степной пасти Томскаго края. Вт нашемъ мгзев имћется гучело, добытое въ с, Таскаевт на оз. Сартлань 27 го іюля 1891 г. 'Џучелю этой же гагары, добытой осенью 1898 г. недалеко отъ ст. Убинской, Каинскаго у., я видълъ тамъ во время нашего пребыванія. На озеръ Убинскомъ довольно часто попадается рыбакаџ', въ, съти и за порчу ихт не пользуется расположеніемъ населенія. Убитыхъ и утонувшихъ гагаръ рыбаки выбрасываютъ на берегъ. Въ, желудкъ одной С. М. Чугуновымъ были найдены камеши (изъ этого экземпляра приготовлент скелетъ). В!. Кулундинской степи әта гагара въ небольшомъ числь особей, въроятно, гиьздяшаяся птица большихъ юзер'ь („Няшино“, "Таратприно“ и „Барсучье“) въ окрестностяхъ деревни Плотниковой. Чернозоо́ся гагара попадается т. н. "гагарникахъ " и охптникамъ на эंтихъ озерахъ сравнительно р'ьдко и въ глазахъ ихъ не представляетъ особенний цынности, такъ какъ скупцики шкурољь дають имь за пару не болье 30 коп. Гагаучь наблюдается и въ окр. дер. Чистоозерской, гды я 29-го іюня 1902 г. безуспьшно преслћцовалъ молодого гагауча, ирекрасно и подолгу нырявшаго и әтимъ спасшагося. Встрбчается около с. Ключевого. Въ коллекціи изъ приалтайскихъ степей экземпляровъ әтой гагары нътъ. По И. С лов иову (стр. 160) гнъздяцаяся птица Барабинской степи. Найдена и въ Кокчетавскомъ убздъ. По А. Морозову (стр. 1) гнъздящаяся птица Омскаго и Петропавлов-

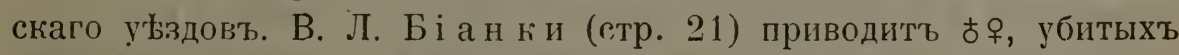
15/vi 99 въ, Акмолинскомъ уъздъ.

Измъренія:

1) ad. sex.? $27 /$ vII 91 ґ. 58 ad. 295 as. 293 c. 70 t. 81. 


\section{Colymbus septentrionalis Limn. Farapa кpacrozo-} бaร.

Свъдънія о нахожденіи этой гагары въ степной части нашего края ограничиваютя сообщеніем' ПI. А ШІІастовскаго о томт, что онъ 18-го мая 1905 г. нашетъ эту гагару близъ ст. Каинскъ. Возможно, что ее сльдуетъ причислить къ гньздящимся зджсь. Пролетаеть она весною по Томи и по Оби и, вброятно, также и по степным озерамъ нашего края. Въ университетской коллекціи сохраняется шкурка этой гагары, доставленная въ музей провизоромт I'. А. Ш тром оергом из изъ окр. гор. Томска въ 1895 г. Это взрослая гагара въ льтнемъ перь. Затьмъ въ моемъ распоряженіи экземпляръ, .юбезно предоставленный мнғ З. Л. К узьми н ой-К орова евой, убитый около Т'юмска 9-го мая 1905 г. Въ зобу его я нашелт щуку и ельцд, въ желулкь полуперевареннаго ельца.

Измтренія:

$$
\begin{aligned}
& \text { 1) sex.? ad. } 95 \text { r. ? a. } 290 \text { c. } 54 \text { t. } 82
\end{aligned}
$$

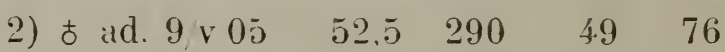

У Біанки, Морозова и Плотникова этоть видъ не упоминается вовсе. М. Д. Рузскій (стр. 24) приводитъ его для южной полосы Тобольской губ въ качеств है гньздящейся птицы.

\section{? Colymbus glacialis Linn. Tarapa mosgphag.}

В. Н. Плотииковь (стр. 23) упоминаетъ изъ гагаръ липь C. glacialis Linn. Мнъ кажется весьма сомнительнымъ, чтобы этотъ именно видъ пролеталъ Иртышюмъ. Желательна провьрка опредъленія.

\section{5\%. Podiceps cristatus Linn. IГоганыа большая.}

Мъстныя названія: „гагара“ (ов. Убинское въ Барабъ), „гагара хохлуша“ (дер. Чистоозерская), „дорогая гагара“ (дер. Чистоозерская и с. Ключевое), „гоголь“ (окр. ст. Каинскъ).

Большая поганка ловольно обыкновенная гнъздящаяся птица района нашихъ изсльдованій. Во время экспедиціи 1899 г. этотъ видъ наблюдался на озерь Убинскомъ, гдъ не пользуетея расположеніемъ рыбаковъ за порчу с'ьтей. Шкурки во время нашего 
пребыванія в’ь Бараб́ь, повидимому, еше не представляли такой ц'Ености, гакъ въ 1902 г. в'т, Кулундинской степи. Трупы убитых'ь нли найденшых мертвыми в', сбтяхъ выбрасывались на берегъ. Изъ одного экземпляра (:. М. Чугуновым б былъ приготовленъ для нашего музея скелетъ. Въ желудю были имъ найдены перья*), пухъ, части жуковъ, небольшія гости отъ головы рыо̆ъ и рыбья чешуя. ПІ. ІІ. С у шкин и **) отмбчаегъ, что „большая поганка встрбчаетея на тнъздовь тыхъ водюемахъ", что вполнь подтверждается нашими паблюденіями на озерахъ нашего крал, но преимушественно она на. селяетъ здъсь тростниковыя и камышевыя заросли озеръ. Мы находили ее въ Кулундинской степи на больших'ь озерахъ около дер. ІІлотниговой, гдђ „дорогая гагара“ несмотря на пресльвдованія со стороны человтіка еще гнбздится. Пресльдуются всљ виды поганокъ изъ за шкурокъ, причемъ дороже всбхъ цЊнятся шкурки большой поганки (до 50 коп. за штуку, другіе вшды отъ 25 до 30 коп. за шшкрку). Ловятъ ихъ петлями надъ гнбздами. Промышленники, занимающіеся ловыею ихъ, называются „гагарниками". Очень обыкновенна эта поганка и на большихъ озерахъ около д. Чистоозерской, у села Ключевого и въ других' мьстахъ. Въ коллекціи изъ приалтайскихъ степей шкурокъ этого вида не имъется; въ музеъ же есть чучело этого вида изъ окр. Барнаула.

Измьренія:

1) ᄒ ad. окр. г. Барнаула 2/r 99 r. 56 ad. 197 as. 200 t. 63

2) ad. д. Плотникова 15 vi $02 \quad 45 \quad 192$

65

Изъ окр. станціи Каинскъ я получилъ отъ П. А. Шастовскаго кладку изъ пяти ненасиженных'ь яиц этой поганки, найденную 22-го мая 1903 г.

Размъры и въсъ яицъ сльдующіе:

$$
\begin{aligned}
& \text { 1) } \frac{55,6 \times 36,5 \text { мм. }}{2,98 \text { гр. }} \text {; 2) } \frac{55,5 \times 38,5 \text { мм. }}{3,68 \text { гр. }} \text {;) } \frac{56,8 \times 36,4 \text { мм. }}{3,16 \text { гр. }} \\
& \text { 4) } \frac{57,0 \times 36,4 \text { мм. }}{3,45 \text { гр. }} \text { и) } \frac{54,3 \times 37,2 \text { мм. }}{3,82 \text { гр. }} \text {. }
\end{aligned}
$$

*) О значеніи перьев'ь, постоянно находимыхь в'ь хелудк' поганок'ь, см. статью R. Biedermann'a „Orn. Jahrb.“ 1897 p. 6.

**) ПТицы Уфимской губ. Москва 1897 стр. 1. 
Изъ этоге же мъста я получилъ затьмъ два яйца одной кладки, взятыя 22 r 03. П. А. Шастовскі ӥ считаетъ ихъ за яйца P. griseigena. Судя по размърамъ и въсу, я могу считать ихъ только за яйца большой поганки, а потому измьренія ихъ

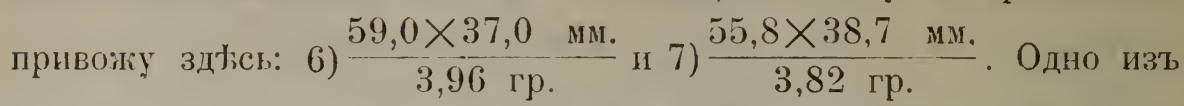
посльднихь я передалъ въ нашъ музей. Періодъ кладки яицъ у большой поганки къ 1亏-му іюня 1902 г. еще не окончился. Я в’ь день отъъзда изъ д. Плотниковой получилъ отъ „гагарника“ самку, изъ қотороӥ при вскрытіи было вынуто почти готовое къ сносу яйцо. Для сравненія съ яйцами западно-европейскихт поганокъ, л пріобрблъ кладку изъ 3 яицъ P. cristatıs изъ Германіи (Mark Brandenburg) отъ 20/v 1/гі 1898 г.

Размьры и въеъ этихъ яиц':

$$
\text { 1) } \left.\frac{56,8 \times 36,0 \text { мм. }}{3,69 \text { гр. }} \text {;) } \frac{56,0 \times 37,0 \text { мм. }}{3,52 \text { гр. }} \text { и } 3\right) \frac{55,5 \times 36,0 \text { мм. }}{4,05 \text { гр. }} \text {. }
$$

\section{Podiceps (Dytes) auritus Linn. IJorinia poratag.}

Мъстное названіе: „гагара-огнёвка“ (дер. Чистоозерская).

Эта поганка, столь обыкновенная въ окр. г. Толска, во время коллектированія въ степяхъ нашего края добыта только въ Ifyлундинской степ. Здъсь она населяетъ вмбсть съ сородичами озера въ окр. дер. Плотниговой, Чистоозерской и с. Ключевого. Я самъ любовался 14 іюня 1902 г. парочкою этихъ поганокъ въ бинокль, стоя неподвижно въ высокой травь около озера. Тихо выплыли онъ изъ тростниковъ и повернулись ко мнь красноваторыжей шеей и грудью. Мнь шришлось сдылать ныссколью движеній, и птицы также тихо и незамбтно, какъ появились, исчезли въ зелени или нырнули.-Найдена въ с. Тулинскомъ на Оби.

\section{Измьренія:}

11 t ad. цер. Плотникова 15 ri 02 r. 22 a. 141 t. 46.

Въ окр. Барнаула и на Алтағ эта поганка встрбчается, приводится И. Я. Словцовым т для Омскаго и Кокчетавскаго убзда (стр. 160), Е. Н. Плотниковымъ для озеръ по Иртышу (стр. 22), В. Л. Бі анки для Атобасарскаго уъзда, (етр. 21), А. М о розовым ъ для Омскаго) и Петропавловскаго уъздовъ (стр. 1), 
В. С. Е.тпатьевски м д д.я Омскаго у'взда (стр. 136). ()дно яйцо поганк, полученное мною въ. дер. Плотниковой 15-го іюня 1902 г. я считаю яйщом' этого вида. Размъјы его $42,0 \times 30$, , мм. при въсғ въ 2,5 гр. Оно хранится въ оологической голлекци нашего музея.

\section{5\%. Podiceps (Proctopus) nigricollis Brehm. IIoranka черношейня.}

Эта поганка населяетъ в', Кулундинской степи польшія изера близъ цер. Плотниковой, по гнћздится и на болье мелкихъ. Встрғтается близь лер. Чистоозерской и у села Ключевого.

Измьренія;

1) б ad. окр. г. Барнаула 19 v 99 r. 22 ad. 130 as. 135 t. 49 ч. 2) б ad. дер. Пллотникова $14, r_{1} 02 \quad 25 \quad 136 \quad 43,5$ ш.

15-го іюня я был'ь очень удивлен'ь, когда в'т дер. Плотниковой одинъ крестьянинь принесъ мнь 15 яицъ изъ разныхъ гнъздъ этой поганки для коллекціи экспедиціи. Я предполагалъ, что періодъ насиживанія уже окончился. Яйца были въ разныхъ степеняхъ насиживанія, нбкоторыя почти совершенно свъжіи. въ иныхъ заключались уже огронные зародыши. Изъ нихъ удалось сохранить для музейской коллекціи десять, изъ 4-хъ нельзя было извлечь зародыша безъ значительной порчи скорлупы, одно лӥцо разбилось на пути в'ь Томскъ. Всь эти яйца не сохранили своего первоначальнаго. основного, бьлаго цвъта, а окрашены въ буроватый цвътъ, здвисящій оть цђлаго ряда внбшнихъ вліяніӥ, а именно сырости, грязи и разлагањщихся въ гнђздахъ растительных'ь веществъ, а также и отъ химическихъ свойствъ воды.

Размьры и въсъ ихт, сльдующіе:

$$
\begin{aligned}
& \text { 1) } \frac{45,0 \times 29,0 \text { мм. }}{1,94 \text { гр. }} \text {; 2) } \frac{45,0 \times 29,0 \text { мм. }}{1,94 \text { гр. }} \text {;) } \frac{44,2 \times 29,2 \text { мм. }}{1,95 \text { гр. }} \\
& \text { 4) } \frac{40,0 \times 29,0 \text { мм. }}{1,84 \text { гр. }} ; \text { э) } \frac{43,6 \times 27,5 \text { мм. }}{1,77 \text { гр. }} \text {; } \frac{43,0 \times 28,0 \text { мм. }}{1,85 \text { гр. }} \\
& \text { 7) } \left.\frac{40,3 \times 30,0 \text { мм. }}{1,80 \text { гр. }} \text {; } 8\right) \frac{43,3 \times 27.4 \text { мм. }}{1,86 \text { гр. }} \text {;) } \frac{44,2 \times 28,2 \text { мм. }}{1,92 \text { гр. }} \\
& \text { 10) } \frac{40,6 \times 30,5 \text { мм. }}{1,72 \text { гр. }}
\end{aligned}
$$


И такъ, максимальная длина яйца 45 мм.; максимальная ширина 30,5 мм.; минимальная длина $\dot{4} 0$ мм., минимальная ширина 27,4 мм. Наибольшій въсъ 1,94 гр., наименышій 1,72 гр. Эти числа довольно хорошо согласуются съ данными, опубликованными въ новомъ изданіи Naumann'a. В九съ яицъ сибирскихъ поганокь пднако н'ъсколько большій.

Біанки (стр. 21) приводитъ эту поганку для Акмолинскаго увзда.

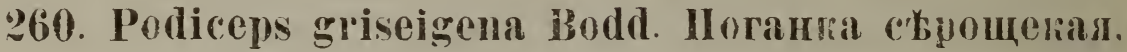

Эта поганка приводится В. С. Елпатьев ским в (стр. 136) для Омскаго убзда, на основаніи молодого әкземпляра, правильность опредьленія котораго самому автору кажется лишъ въроят ной. А. Морозовъ (стр. 1) приводитъ этотъ видъ (P. rubricollis Lath.) въ качеств' гнђздящейся въ Омскомъ и Iетропавловскомъ уу. птицы повидимому со словъ И. Словцова (стр. 161). Нами въ степяхъ нашего края не добыта. Уже Палласъ указываетъ на Барабу („Colymbus cucullatus“ p. 355). М. Д. Р у зскіӥ (стр. 24) приводитъ эту поганку для южной полосы Тобольской губ.

\section{? Podiceps minor Linn. Iloranka hatas.}

А. Морозовъ и В. Н. Плотниковъ указываютъ ни нахожденіе малой поганки въ Омскомъ и Петропавловскомъ уу. и по Иртышу. Это указаніе, по моему мнћнію, нуждается въ провъркћ, хотя сьверная граница ея области гнъздовья не вполнђ вылснена. Намъ нигдъ въ степной части нашего края не попадалась. Не упоминается она ни В. Л. Біанки, ни М. Д. Руззкимъ, ни В. С. Елпптьевским и. 
XIII. LAMELLIROSTRES. (П.ластинчатоклювыя).

\section{Ð(61. Phoenicopterus roseus Pall. Фламино-rpacho- Кำ H.T'}

О гивздованіп краснолрыла вт степной части нашего края иичего неизвъстно, о залетахь же его имъется ньсколько указаній. Такъ въ Nㅡ 15 Тонскихт Гуо́ернскихъ Вждомостей за 1870 г. я нашель замбтку С. Гуляева. („О ф)ламингахт, въ алтайскомъ горномъ округъ́), въ которой соошщается, что осенью 1852 г. семг фламинго появились вт 50 в. отъ Бійска; изъ нихъ три фламинго были убиты и отправлены въ Барнауљьскій музей, гды изъ нихъ было сдълано два чучела. Вт, той же стать Б С. Гуляева сообщается, что въ октябрь 1869 г. близъ дер. Копыловой, Чумышской волости въ 85 верст. отъ Барнаула появилось два фламинго, изъ которыхъ одинъ быль убитъ. Экземпляръ этотъ молодой; въ стать' дается описаніе его и нькоторыя измъренія.

Во время нашихъ побздокъ по степной части нашего края гіраснокрыль намъ не попадался. Во время пољьздки 1899 г. я со словъ А. А. Аргунов а записалъ въ дневникъ, что имъ львтъ 15 тому назадъ была куплена шкурка фламинго, недавно убитаго, у крестьянина на базарь въ г. Каинскъ. Но это не единственный случай залета краснокрыла въ Барабинскую степь. П. А. Шастовскій сообщаетъ мнб, что 11 -го мая 1904 г. на базарғ ст. Каинскъ продавали двухъ фламинго, а 17-го иая того же года онъ самъ видъль на большом' озерь въ $4 \cdot \mathbf{x}^{\prime}$, верстахъ отъ города Каинска трехъ фламинго ${ }^{*}$.

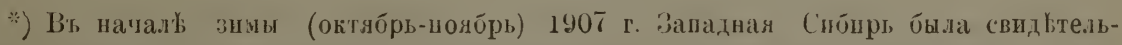
ницеиі грандіознаго залета краснокрыловь-()ламинг. В'в моехь распоряженік пока даты относительно появленія фмаминго въ окрестностяхъ Омска п Семипатинска, в'ь уъздахъ Капнскомь и Барнаульскомь, Кузшедкомъ, Томскомь и Маріинскомъ. Насколь-

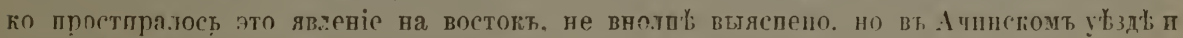

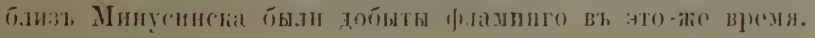




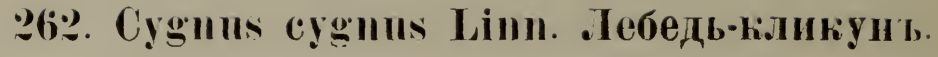

$$
\text { (= C. musicus Bechst.) }
$$

Јебедь-кликунъ все еще довольно часто встрђчается на гнђздовь'ы въ степной части нашего края. Въ Барабинской степи онъ гнґздится в’ь пкр. станціи Убинской, въ окр. Каинска, откуда въ моей коллекціи кладка изъ четырехъ яицъ, наӥденныхъ 9 мая 1903 г. и любезно предоставленныхъ мнъ П. А. Ш а стов с Размғры яицт $118 \times 74 ; 118 \times 74 ; 119 \times 74$ и $114 \times 75$ мм. Изъ другихъ мъстностей Барабинской степи, расположенныхъ по линіи же.л. дор., инб сообщали о лебедъ, какъ о пролетной птицъ. По Обл въ предълахъ напего грая кликунъ очень обыкновенная птица. В'ь Кулундинской степи онъ вмњсть ст гусями гнЊздитсл по большимъ озерамъ въ окр. деревни Шлотниковой (Няшино, Тараторино, Барсучье, Горыюе), на остальныхъ же бываетк только шролетомъ. На озерахъ близъ дер. Чистоозерской онъ, повидимому, не гнбздится, но въ с. Ключевомъ по озераиъ водится

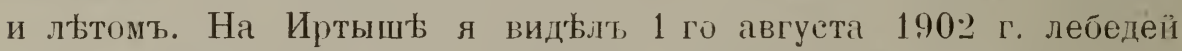
выше г. Навлодара. Казаки станицы Семиярской считаютъ лебедей только пролетными.

Изъ литературныхъ данныхъ (А. Морозов ъ, В. Н. Плотни ковъ, И. Я. Словцовъ и М. Д. Рузскіӥ) явствуетъ, что лебедь-кликунъ довольно обычная фориа по всымъ степнымъ озєрамъ, не лишеннымъ растительности. Прп этомь лебеды, пе изббгаетъ и содержащихъ соль озеръ.

Въ нашихъ коллегціяхт, экземпляровъ изъ степной части Томскаго края ныть.

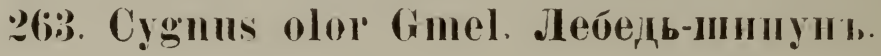

Между тьй какт всь видыные мною изт окр. Томска и yónтые на Оби лебеди несомнъино кликуны, на основаніи литературныхт, данныхь приходится вғыючить и шипуна вт, перечень птицъ степной части нашего зрая. Уже Палласъ, говоря о шипунь (стр. 215. Cуgmus sibilus), сообцаеть „in Sibiria rarius occurrit", по имъ не приводятся мұстонахожденія. У И. Я. Словцова (стр. 233) я нахозяу указаніе, что ,обширныя стада Суgnus musicus и olor гнЊ:здятся B'ь самой южной части Тюкалинскаго округа“. А. Морозов в въ своемъ спискь танґіе сообщаеть, (стр. 3), что кликунъ и шипунъ „обычныя формы на вс'вхъ 
степныхь озерахъ, гдђ есть камьши, ие исключая и горькосоленыхт“. Вт, 1870 г. И. Я. Словц ов з (стр. 158) встрбчаль шипуновъ большми стаями на озерахъ въ котловннь Чановъ, гды они остаются на льто.

\section{4. Суğus bewicki Yarmel. Малый .лебедь.}

Малый лебедь указывается однимт лишь И. Я. Словцовымь (1897 стр. 158). Вьроятно малыиі лебедь лишь въ качествъ пролетной птицы посьиаетъ степи Западной Сибири. такъ какъ зимуенъ въ Туркестанғ. Изт, предьловъ Томскаго края въ нашихь ко.лекціяхъ экземпляровъ нжтъ.

\section{?(i.). Anser anser Linn. Cねрый гусь.}

$$
\text { (= Anser cinereus Meyer = Anser rubrirostris Hodgs ) }
$$

СБрыӥ гусь гныздящаяся птица нашихъ степей. Вт Кулундинской степи мы находили его по большимъ озерамъ близъ д. Плотннковой (недалеко оть Оби), называемымь Няшино, Тарато• рино, Барсучье, Горькое. „Гагарники“, занимаюціеся ловлею поганокт на этихъ озерахь, доставили намъ двухъ пуховыхъ птенцовъ сърыхъ гусей, лойманныхъ 15-го іюня на оз, Тараторинь. Покупка ихъ не состоялась, такъ какъ не могли сийтись относителлно цьны. Въ окрестностяхъ дер. Чистоозерской я убиль молодого сьраго гуся. Этихъ же гусей мы видъли близь ст. Семиярской нбсколько разъ. Особенно много ихъ было 27-го іюля на львомъ берегу р. Иртыша на посьянномь киргизами прось. Размьры и вьсъ двухъ сильно насиженныхъ яицъ изъ Бараб́инскої степн, взятыхъ 15-го мая 1903 г.

$$
\text { 1) } \frac{82,3 \times 59,0 \text { мм. }}{17,72 \text { гр. }} \text { и) } \frac{89,7 \times 57,5 \text { мм. }}{19,20 \text { гр. }}
$$

(). Finsch (стр. 259) часто наблюдалъ пролетныхъ сьрыхъ гусей между Омскомъ и Павлодаромъ. Подъ Омскомъ сърый гусь по) И. С ловц о в (стр. 158) и А. Морозо в у (стр. З) выводится въ долинћ Иртыша и по большим озерамъ въ степи, гды найденъ и В. С. Елпатьевски м (стр. 143), По В. Н. Плотн ІІ кі ву (стр. 21) этоть гусь водится въ окрестностяхъ пос. Ямыневскаго в’ь огромномь количесть'ь. М. Р у в к ій (стр. 24) сообцаетъ, что наша птица гшъздится въ южной полось Тоболь‘кои губ. По С. А. Бутурлину сєрый гусь гнбздится въ до- 
линъ Об́и до полярнаго круга. С. А.лфера ки (стр. 22), къ сожальнію безъ подробныхъ указаній, соойцаетъ, что эта птица гнћздится въ Томскомъ крағ. Экспедиція П. Г. Игнатова (см. В. Біанки гтр. 18) нашла этого гуся въ качеств Бн гнвдящейся птицы въ Атбасалскомт, и Аюмолинскомъ у.

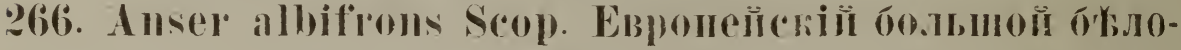 .}

Въ качествћ пролетной птицы на озерахъ близъ д. Чистоозерскй п с. Ключевого ежегодно осенью вєтрбчается бұлолобый гусь; но тагъ какъ этоть факть записань у меня лишь со словъ мћстныхт, жиятелей, то пстается открытымь вопросъ, какая форма (Anser gambeli Hartl. или Anser rhodorhynchus Buturlin) останав.тивается на этихт озерахт. По А. Морозову (стр. :3) Anser albifrons выводится вт степяхт, Петронавловскаго, Акмолинскаго и Атбасарскаго у., по не держится вовсе по Иртышу. В. Н. Плотни ко в ь (стр. 21) для окрестностей пос. Ямышевскаго сообщаеть, что бълолобый гусь не водится осьдло, а лишь встрьтаеся пролетомъ веснон п осенью въ болыпмъ количествь. По И. Я. С.ловцову (стр. 234) онъ найдень подъ Тюменью только на пролеть́⿱一𫝀 весною и осенью. С. Алфераки (стр. 39) не отдъляеть европейскаго большого бьлолобаго гуся отъ азіатскаго.

\section{6\%. Anser erythropus Limn. Европейскій милый бъло-

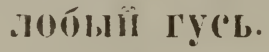

$(=$ A. minutus Naum. = A. finmarchicus Gumner. $)$

По Словцову (стр. 234) поцъ Тюменью встрьчается только весною, хотя охотники увьряють, что әтоть гусь остается на лћто. С. Алфе раки (стр. 5у) сообцаетъ, что этотъ гусь пролетаєтъ въ большей части Западной Сибири. Этотъ авторъ соединяетъ А. lhodorhynchus Buturl. съ А. erythropus Linn.

\section{-- Anser cygnoides Linn. Kuтайckin̈ rycь.}

$$
(=\text { Cyguopsis cygnoides auct.) }
$$

По сообщенію фельдшера ст. Семиярской Н. М. Фреймунда въ 15 в. отъ урочища Чушкалы на одномъ озеръ водятся китайскіе гуси. О. Finsch (стр. 2.5s) видыль этихъ гусей на Черномъ Иртышl;. 


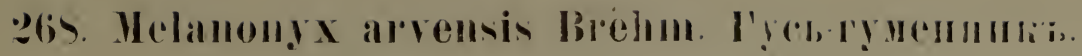

$$
\text { (=Anser segetum (imel. anctrimm.) }
$$

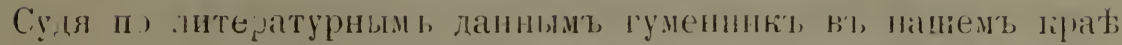
не только пролетная, но и тнъздящаяся птиц. См. (ловцова

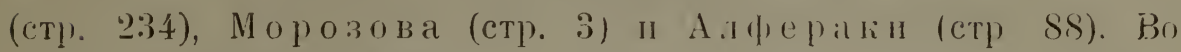
время повздокт, не добытъ.

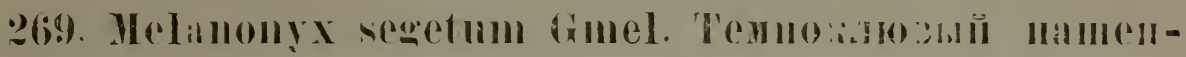 Iйій Iy(') и}

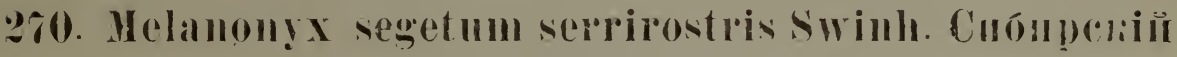 nзиениы тусн.}

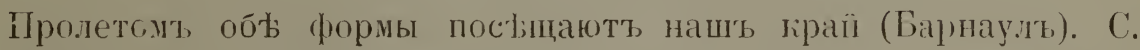
А л фе раки доставлены проф. Н. Ө. Каше нко и мною гуменники изт нашего края. (см. С. А лфераки стр. 110 и 118).

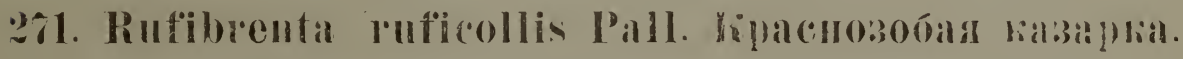

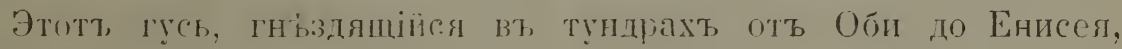

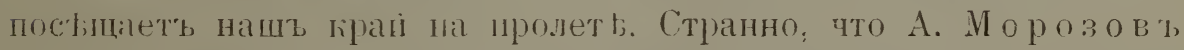
(“тр. 3) сообицетт, что „представите.и рода Bernicla ветржчаются

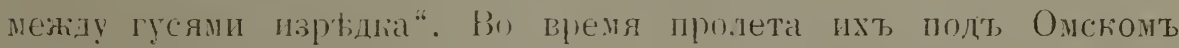

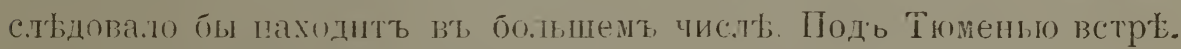

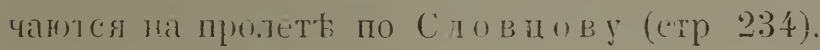

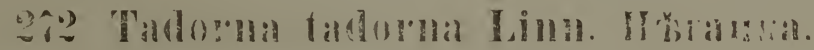

$$
(=\text { Tildunar cornutia Gmel.) }
$$

Мьстн. назв : „атайка“, „атая“ (въ Кулунд. степи).

Въ Барабинской степи пьганка найдена въ небольшомъ чи-

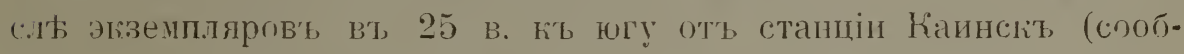
щено ІІ. А. ІІІ астов скииъ). Мы находили ее вт Кулундинской степи гньздящейся вт, небольшомъ числь парт вт, окрестностяхь дер. Плотниковой, Чистоозерской, с. Кличевого; чаще попадалась она около Нияняго Кү̣ука, найдена и близъ станицы Семияр-

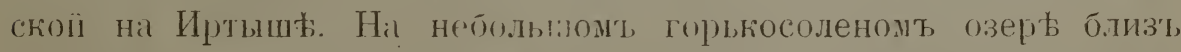

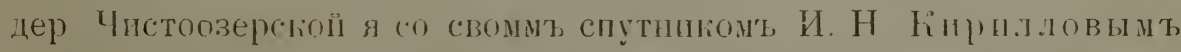
нащли цвлую семью пьганюғь. Самець присутствоваль при семгт,

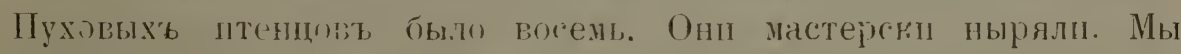
добыли сампа, сами! и диухт, птенцивъ. Недалено оть деревни 
Нижній-Кучукъ стоить зем.тянка-зимовье одного киргиза, незанимаемая владыльцаи съ наступленіемт, теплаго времени года. Здљсь. въ обширной, русской " печи во время отеутствія хозяев' располагается пьганка. Несмотря на то, тто весною 1902 г. у ней было взято 14 яиць, она продолжала нестись. IIn А. Моровов у (стр. 3) пьганка „держіится всегда прбсныхъ водъ“. Съ этимь несогласуются какъ наши наблюденія, такъ и наблюденія В. С. Елпатьевскаго (стр. 143) и В. Н. Плотникова (стр. 19). По мнбнію С. А лфер аки (стр. 7) , атайкой“ въ Западной Сибири называють, главнымъ огразомъ, сльдующій видъ.

Измғренія эк:земпляровь коллекціи:

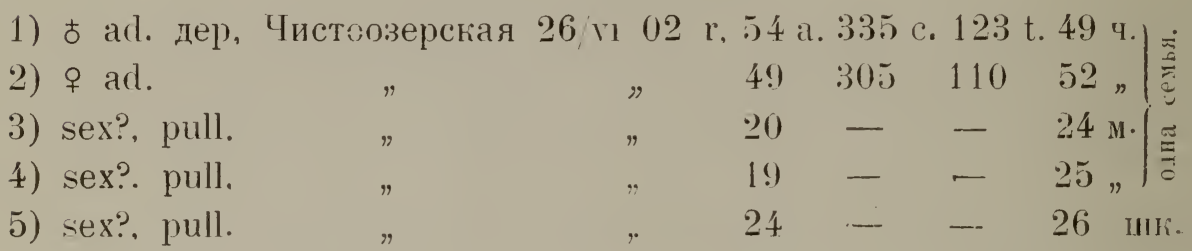

\section{g73. Casarca casarca Linn. Kipachas y'ria.}

$$
\text { (=Tadorna rutila Pall.) }
$$

Мъстн. назв.: „варнавка“ (Кулунцинская степь), „турпань," (станица Сениярская).

Свъдьній о нахожденіи красной утки въ Бараоинской стени пока не имжется. Около станціи Каинск'ь по сообщенію П. А. III а с тов скаго ея положительно ныть, но по сооценію охотника Е. ІІ. Горобунова иногда попадаются „грасныя утьи" близь с. Коченева. Въ юяной части Кулундинской стени она встрьчатся чаще: чьмт, вт сьверной. Въ моемт дневникь запи. саны сльдующія мбстонахожденія ея: окр. дер. Чистоозерской (рьдко), Нияняго Кучука, гдъ она по сообенію мьстныхъ жжителей иногда гнъздится въ искусственныхъ дуплахъ, разставляемыхъ человђкомъ, каюъ гоголь вт, д. Чистоозерскиї (см. ниже); мны самому ничего указываюшаго на факть подобнаго гнь̆здовья

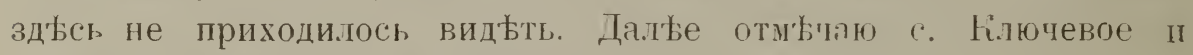
станицу Семиярскую на Нртышь.

Экземпляџт, коллекци:

1) sex? juv. aut jun. с. Кiлючевое y 


\section{yit Anas boscas Limn. Kipstiba.}

Һряква повсемђстно гнђздится въ стешной части нашего края. П!ховые птенцы әтой !тки были добыты \&-го іюня 1899 г. на озерь Ураковомъ близъ станціи Уо́инской въ Барабъ. Там' же уо́ита старка и пойманъ пуховой птенец' $12 \cdot г о$ іюня. От'ъ П. А. II астов скаго я получиль 4 яйца кряквы изъ г'нъзда, найденнаго имт 15-го мая 1903 г. на поль, въ сухой мъстности близъ станціи Каинскъ. Кладка состояла изъ 8 яицъ.

Разитры и вьеъ яицъ сльдующіе:

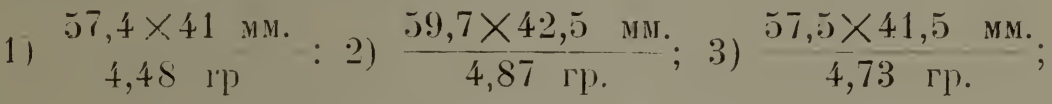

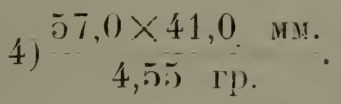

Вь окр. станціи Каннск на ғочкъ болизъ озера дворовая утка нанес.ла 12 яицт, изъ которыхъ, одно доставлено мнъ. Оно было взято ․ㅡ-го мая и значите.льно крупнье яицъ дикой кряквы. Размғры его $66,0 \times 44,0$ мм. при в'ъс ђ скорлупы въ 5,9 гр. II. А. III астовскі й 2-2-го жая 1903 г. нашель на одной кочкъ тамъ же еще два гнђзда кряквы ст 8 и 12 яйцами и между ними гнъздо чирка-трескуньа (Querquedula querquedula L.) съь двумя только яйцами. Во врема побздки 1899 г. я находилъ крякву б.изт. ст. Коченевой и ст. Татарской. Къ Кулундинской степи ғряква довольно обыкновенна у дер. Плотниковой, по озерамъ въ окр. с. Выльова іл въ другихъ мбетакъ, много разъ упомянуTHX

Экземпляры кол.єекціи:

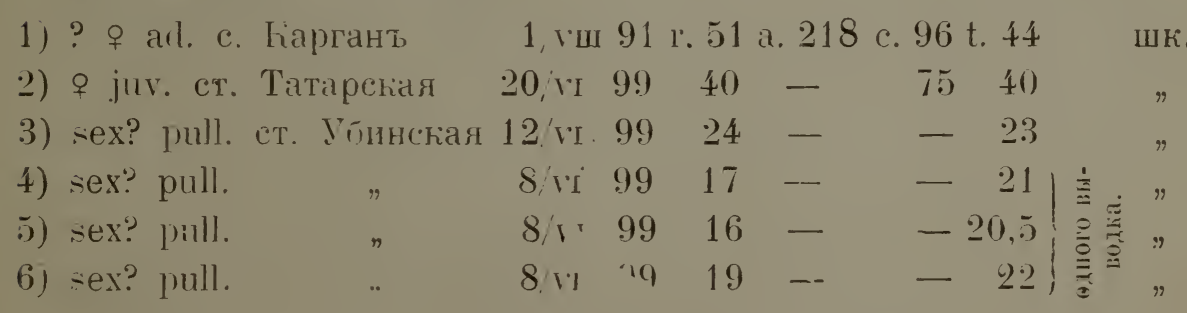

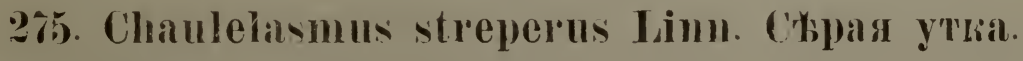

Ућстн. назв.: „с ћрягт, “ (с. Ключевое).

Сћрая утка, хотя и въ небольшомъ числь, гићздится въ Барабъ. 
11. А. Шастов скій убиль 28-го мая 1902 г. б этого вида б.шизъ ст. Кіаинсюь, а 14-го мая 1903 г. нашель тамъ же гнфздо этой утљи съ $\$$ яйцами.

Разиьры и вьст яицъ:

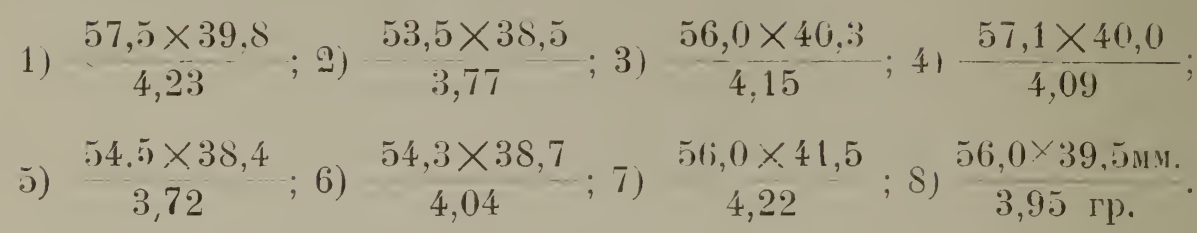

Одно изъ этихь яицт мною передано въ нашъ музей.

Въ Кулундинской степи с'ьрая утка попадалась нам не особенно часто. Вт окр. дер. Чистоозерской ной спутникт, Н. К ириллов у убнль сьрую утку, но, къ сожальнію, пзъ нея не было сдылано препарата. Экөндиція проф. В. В. С а п о жн и о в а 1902 г. доставила въ нашт музей эгвеипляр со ст. .Јебяжьй (между Јавлодаромъ и Семипалатинсломъ); его размбры:

1)

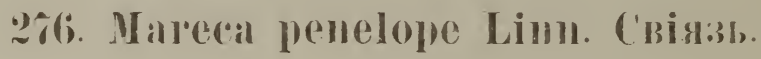

Мьстн. назв.: „свизь“ (дер. Чнстоозерская).

Свіязь очень распространена на гиъздовь'; въ разсматриваемой мћстности. Њғ Барабонской степи она наб.людаласт, вдоль .инин жельзной доропи около станціп Коченево, въ окр. Каинска. Въ Кулундинской степи ее находили близъ дер. Чистоозерккой, с Ключевого. Въ поей частной коллекпіи әкземплярь пзъ (. Тулинcharo на Оби.

Изитренія:

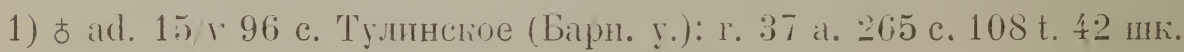

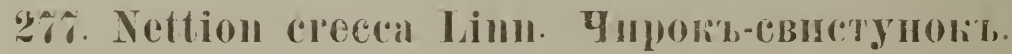

Эта утка въ Барабинской степи встрбчается довольно часто. Въ Кулундинской степи добыта въ разныхъ мћстахъ, ніпр. близъ д. Плотниковой, Чистоозерской, с. Ключевого. Встрьчается подъ Барнауломъ. эгземпляы вт, большинтв Эгспедиція проф). В. В. Сапожникова доставнла вт нашъ музей әкз. изь, ст. Лебяньей (Павлодарт-Семппалатннсюь). 
Иззтіреиія:

1) む a1. ст. Аебянья 9 ॥. 02 г. 37 а. 176 с. 66 t. 29 шк

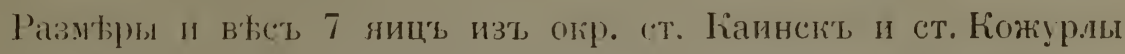
отт. П. А. ШІ астовска го, вззятыхъ 15-го и 17.го мая 1905 г.:

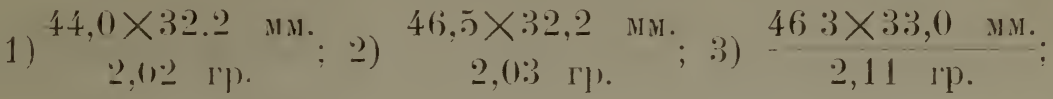

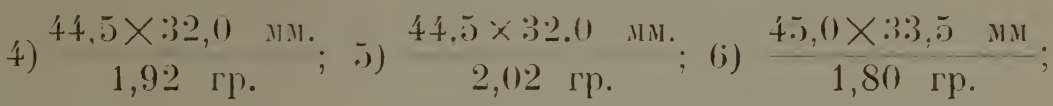
7) $\frac{44,0 \times 32,0 \text { нм. }}{1,87 \text { гр. }}$.

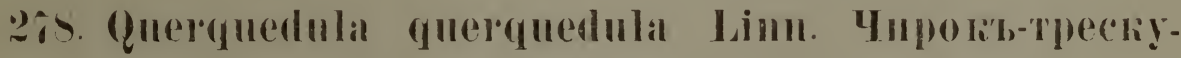 II0 KH.}

Этотт, чирокъ во множеств Бे гнбздится вь, Барап̆инской степи н періодь клации яицъ у него начинается нъсколько поздиђе,

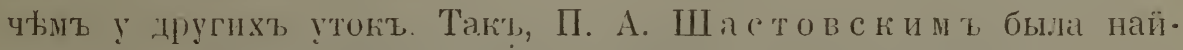
дена 22 го мая 1903 г. близ'ь ('т. Каинслэт лишь неполная кадка изт пвухт яицъ, любезно предостав.ленныхъ имъ мнђ.

Размтры и вбс'ь их'ь:

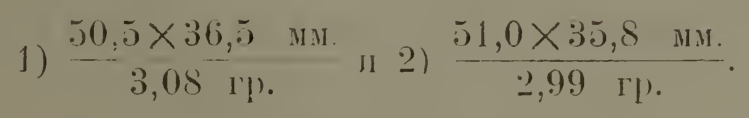

Одно изъ этихт яицъ мпок передано в', университетстію

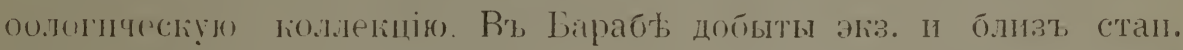

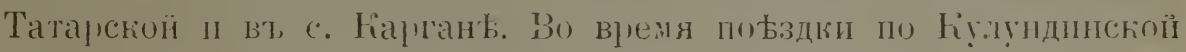
степи мы набоюдали и уо́ива.ли этих' чпрковъ въ окр. с. Камень, л. Плотниюовой, на озерахъь близғ, д. Чистоозерской, с. Кілючевого; въ моей частной фіолегціи имьется экземп. изъ с. Тулинскаго. Экспедиціею проф). К а ш ен кі 1900 ғ. этотъ чирокъ добытъ на озерь близъ с. Локоть.

Изиюренія:

1) $ᄒ$ ad. с. Тулинское

2) б ad. с. Kapгань

3) o ad. ст. Tатарская
$24 \mathrm{r} 96 \quad$ r. 37,5 a. 190 c. 73 t. 29 шшћ.

1 rim $91 \quad 40 \quad 190 \quad 66 \quad 30$ "

17 rI $99 \quad 35 .=18070 \quad 29 "$ 


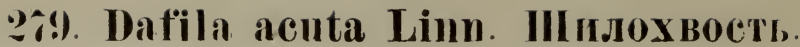

Мьстн назв: „острохвостая“ (потти повсембстно).

Вь Барабинской степи эта утка весьма обыкновенна, а мвстами встрьчаетея массами, кань напр. Вт, пюр. станціи Каннскъ, близь ст. Татарской, Коченева. Въ Кулундинской степи по озерамъ около дер. Шлотниковой этотъ видъ рьиительно преобладаеть наль другии иисломь особей; массами встрђдаетя шилохвость и у дер. Чистоозерской, по Степнему Кудуку и на усть⿱ рьки Кулунды, у с. Ключевого; въ Семпшалатигской области мы нашли ее близъ стапицы Семиялской. Около Барнаула обыкновенна.

Экземп.яры кол.текиі:

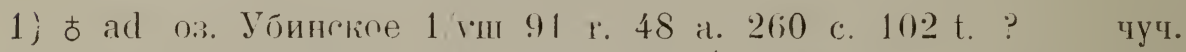
2) 9 ad. Уст. р. Кулунды ј 3) sex? pull

4) sex? pull.

5) sex? pull.

$20 \quad-\quad-\quad 19)$

6) む ad. окр. г. Барнаула $\&$ гі $98 \quad 50 \quad 260 \quad 2050$ 40.5

\section{Dafila acuta Limn. $\times$ Anas boscas Lim!.}

Изъ окр. Барнауда въ коллекціи А. П. Велижанина я видылт гиорида, убитаго 15-го мая 1898 г. б.

\section{Spalula clypeata Limn. Colicynto.}

Мбетн. назв.: "соксонъ" (дер. Чнстовзергкая).

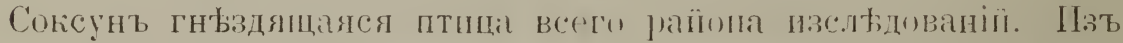

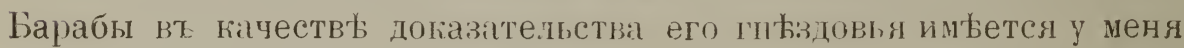
к.лацка изъ пяти яицъ этой утки, любевно доставленныхь мны

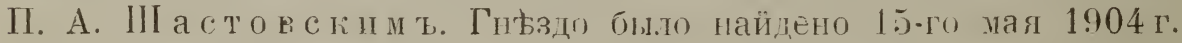
близъ станціи Каннскъ.

Размтры и вьст, яицг:

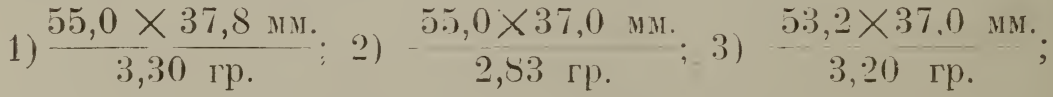

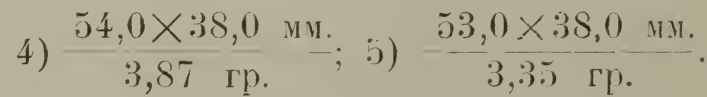

Одно яйцо поступило въ нашь музей. 
Вь Гучлуцдинсьй стени эті утка попадались вт, окр. дер. 'Іистоозерской; по Иртышу она ветрғяается, можетъ быть, чаще. Вэ, станицт; Семияргкой намь, иринесли 28-го іюля 1902 года трехт молюыхт, пойманныхт јіияыми; они всл'вдствіе недостаточнаго развитія маховыхъ не въ сөстояніи были летать. Ихъ не взяли; также осталась непрепарированной старая + , мною здъсь уо̆итая.

Эк:земп.иры колтекиіӥ:

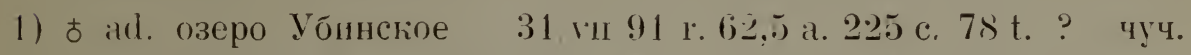

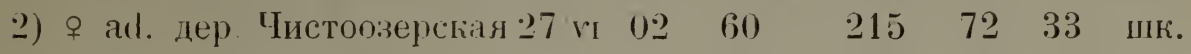

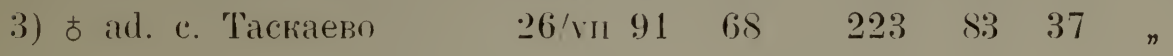

Подъ Барнау.ломъ гнђздится. Экспедиціею 1900 г. этотъ видъ найдент, б.иизь с. Локоть.

\section{¿\$1. Netta rufina Pall. Kipacноклювый нырокт.}

Мв̆стн. назв.: „канйвора“ (дер. Чистоозерская.)

Совершенно негодную для препарировки шкурку этого нырка (ち въ брачномт, опереніи) доставилъ намъ Ю. Л. Н е слухов ск ій на ст. Убинской въ Бараббъ, во время нашего тамъ пребыванія въ 1899 г. Экземплярт, былъ убитт, тамъ же на оз. Ураковомъ за 5 дней цо нашего приоытія на эту стантюю (3 іюня) изъ стайки въ семь штукъ. По сообенію П. А. Шастовскаго онъ этого нырка около ст. Каинсіъ не встрбчалъ. Другими свьдьніями о нахожденіи этой утки вт Барабинскої степи я не располагаю. Въ, Кулупдиской степи эта утка мћстами встрбчается во множествт, напр. на нбкотирыхь озерахъ близъ дер. Чистоозерской, гдњ я убил одну самку. Ұкспедиціею прою. В. К. Са по жн и кова ғ’ нашъ музей доставлена шкурка со ст. .Тебязьей (тоже ф).

Что касается географическаго распространенія красноклюваго нырка, мнб приходится указать на ньсколько неточностей въ дэстпной мнђ литературђ. Проф. М. А. Мензбиръ въ своемъ сочиненіи „Птицы Россіи“ (стр). 6.50) не указываетъ сьверной границы опласти гнђздовья этого нырка въ юго-западной (ибири. Равнымъ образомъ, С. Алфераки въ своемъ роскошномт, но, къ сожальнію. все еше незаконченномъ сочиненіи „Утки Россіи“ (стр. 133) о нахожденіи әтюй утки въ Сибири умалчиваетъ, а упомшнаетъ лишт, Туркестанъ. С. А. Бутур.тинъ, вт, „Синопти- 
ческихь тайлицахъ" (1901 г. стр. 5ј) указываетъ ла южныя части Тургайской и Аюмолинской юбластей. По В. .Т. Біанки наша утка добыта въ іюнь въ Атоасарском и Акмолилскомъ уыздахъ. А. Морозовъ считаетъ этихь нырковъ, наблюдавшихся въ районъ его изсльдованіӥ, лишь за пролетныхъ, но на Иртышы ихъ В. Н. Плотников т, повидимому, ни разу не видьль. Изт литературы я вывожы заключеніе, что красноклювый нырокл. уже со времень Палласа (Zoographia pag. 25:3) извьстенъ для нькоторыхь мъетьь юго-западной Споири (Исеть), но что онъ въ ћиче-

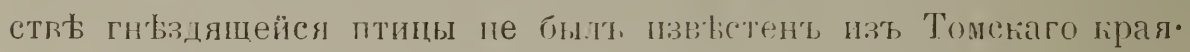
B's „Ornithol. Jahrbuch" (1902 (тр. 5) я вшервые указаль на на“ хожценіе этого вида въ Каинском уьздь Томской губ.

Экземг.Іяры юо.лекції:

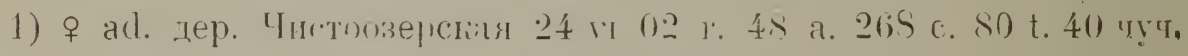

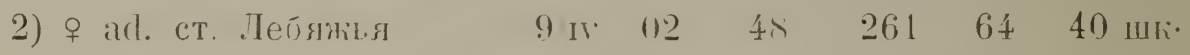

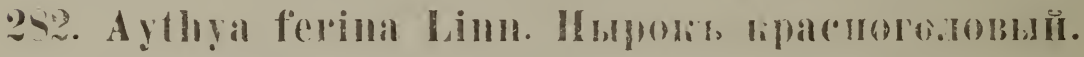

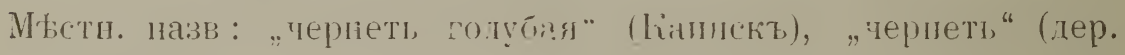
Чистопзејская).

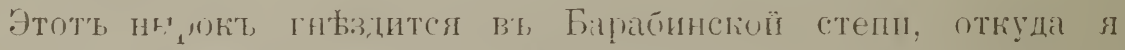

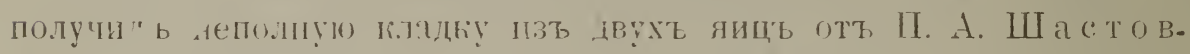

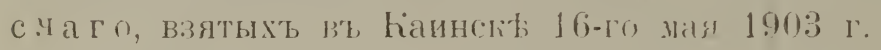

Paзмьры и в

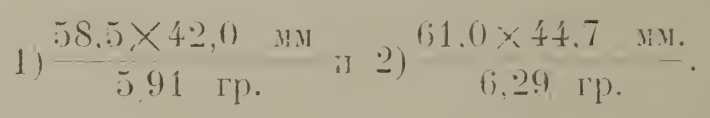

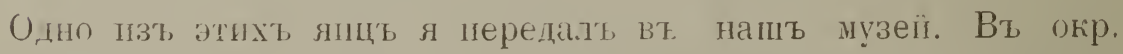
ст. Каинскъ этотт нырокъ очень ои́нновененъ и встрџчается чаще друиих видовь. Въ нашемъ уузеђ имботся экземпляры, уолтые на озерб Чаны вт 1891 г. близъ ц. Кеашниной, какъ взрослые, такл, и пуховый птенецъ. Њт Кілучдинской стени мы добыли әту утку въ окр. дер. Чистоозерской, гды пна обыкновенная гнбздяшаяся птица. Встрьчыется она доводьно часто и въ окр. Барнаула п вт гіниатайских степяхт.

Измьренія:

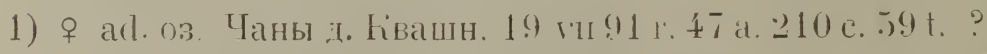

บ!ับ.

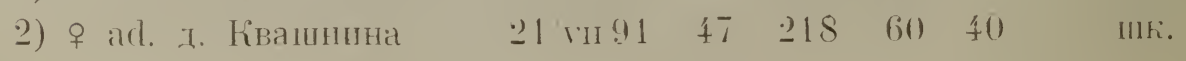


3) ㅇ ad. дер. Ківашпина

19 เ. 91

$46, .5208$

$58 \quad 39$

แแк.

4) sex? pull.

$$
\text { 19/VII } 91
$$

31

у) \& дер. Чистоозергкая

24 พr 02

44

210

$22 \quad 28$

6) sex? pull.

7) sex? pull.

$"$

20

$$
2
$$

8) ad. дер. Бороду.пиха

18,1100

$\begin{array}{ll}60 & 37\end{array}$

9) o ad. окр. г. Барнаy.ra

21, ri 98

$49 \quad 220$

$46 \quad 220$

$13 r 99 \quad 46, \check{2} \geq 11$

37
$-\quad 20$
$-\quad 2.2$

56 41

ШК.

10) $\delta \mathrm{ad}$.

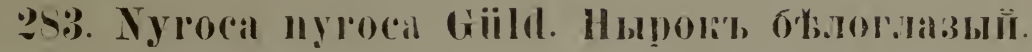

Нырокъ бълоглазый, по союбщенію О. фон ъ-Д и тм а а имъ былъ убитл, 2-го ію.я 1899 г. оголо г. Колывани на р. Чаусћ. Около Каинска че найденъ П. А. ІІастов ским ъ. Намъ во время поъздокъ по степной части Томскаго края не попадался. По А. Морозову (стр. 3) прннад.тежитъ къ гнъздящимся птицамъ района его изсльдованій. В. Н. Плотниковъ на Иртыш‡, убилъ пару этихъ нырковъ, въроятно пролетныхъ (стр. 20.). По И. Слов цо ву (стр. 160) „встрбчается часто по Горькой линіи; одинъ экз. убитъ вь Анртавской станицб 7-го іюня".

\section{- Fuligula marila Limu. Чennets mopchas.}

Чернети морской изъ степной части Томскаго края въ нашихъ коллекпіяхъ не имьется. Одинъ экз., на этикеткъ котораго значилось это названіе, при провърк' опредъленія оказался чернетью хохлатой (см. № 284).

\section{Fuligula fuligula Limn. Чернет, xохлaтag.}

$$
\text { (=Fuligula cristata auct.) }
$$

Мьстн. назв.: „косуха“ (дер. Колдаба близъ ст. Каннскъ).

Чернеть хохлатая въ Барабинской степи довольно пбыкновенная гнбздящаяся птица. Вт моей коллекціи имбется кладка изъ пяти яицъ әтого вида, взятыхъ П. А. Шастов сіи и в 18-го мая 1903 г. близъ ст. Каинск'є.

Размбры и вбсъ нхъ:

$$
\begin{aligned}
& \text { 1) } \frac{55,5 \times 43.0 \text { м.. }}{5,44 \text { гр. }} \text {; 2) } \frac{58,5 \times 44,5 \text { ми. }}{6,09 \text { гр. }} \text {; 3) } \begin{array}{c}
60,2 \times 44,0 \text { мм. } \\
6.05 \text { гр. }
\end{array} \\
& \text { 4) } \frac{58,5 \times 43,5 \text { мм. }}{5,19 \text { гр. }} \text {;) } \frac{58,5 \times 44,5 \text { мм. }}{5,67 \text { гр. }}
\end{aligned}
$$


Одно изь этихъ яицъ л передаль въ нашь музей.

Въ Кулундинской степи этоть нырокь былъ добыть б.лизь с. Ключевого (Барн. у.), но шкурная не бы.та сохранена. Приводитея В. Л. Біанки (стр. 19) для Ато́асарскаго у. на основаніи соборовь әкспедиціи ПІ. Г. Игнатова. По А. Морозову (етр. З) гнұздящаяся птыца „по камышевымъ озерамъ“, но В. С. Ель п т тевски м ъ (стр. 142) наӥдена лишь на оз. Кізылъ. Каьъ. По В. Н. Ш лотни ко ву (стр. 20) гньздящаяся птцца.

Экземплярь коллекціи:

1) $q$ ad. оз. Kута, с. Таскаево $25 /$ vil 91 r. 39 я. 195 с. 52 t. 37.

\section{5.). Clangaula clangula Linu. Гоголь.}

Гоголь, широко распространенная зъ нашемт, краћ на гнћздовьт птнца, вт, Барабинской степи въ нғкоторыхъ мбстахь отсутствуеть, какъ напр. в’ь окрестностяхъ ст. Каннскь по сообщенію П. А. Ш а с товскаго, гдъ гоголями зовутъ Podiceps cristatus L. Вь Кулупдинской степи гоголь мьстами очень обыкновенент, какт нашр. въ окр. с. Вылкова. Въ д. Чистоозерской я былъ весьиа пріятно удивленъ, найдя гоголя, считаемаго всюду крайне осторожной птищей, въ полуодомашненнощ состояніи, гнбзџящимся въ неносредственномт сосьдствђ съ человькомъ, на дворахъ ғрестьянъ этой деревни, въ нарочно устрапваемыхъ для гоголей искусственныхь дуплахт въ родь скворешенъ, разумъется сотвђтствующиъ разићровь. Гоголь въ окрестностяхъ этой деревни встрђчается въ большол количествь и это явленіе за. висить оть отношенія человька къ птицамт, Нћсколько десятков' льть тому назацъ крестьяне этой деревни (я не ногъ узнать, по чьей иниціативь) постановилн вполнь прекратить и запретить охоту на утоюъ въ теченіе весенихъ и льтнихъ мъсяцевъ. При этомъ вошло въ привычку ставить по берегаиъ озеръ на кольяхъ и столбахъ ящшки для гнъздъ. Это не болье какъ выдололенные бревна ст широкимъ летнымъ отверстіемт, прикјваемыя сверху землею или дерномъ, и находятся на разстояніи около сажіени отъ земли; но нбкоторыя дупла подвьшиваются и выше. На дворь одного крестьянина, на цорядочномъ рлзстояніи отъ воды, я видълт пьсколько гнбздь, подвъшанныхъ къ старымъ соснанъ на висоть около 3 саж. По берегу маленькаго озера близт этой деревни было разставлено пе менће 200 тапшх сооруженій для 
гоюлен. Шьль, песльдуемая пнстияерскими обынателями, по.ученіе яиць, употребляемыхъ въ пицу. Клаци, каю' сообицали мнь, состонть изา, 10-12 яиць. Два раза яйца отбираются, но

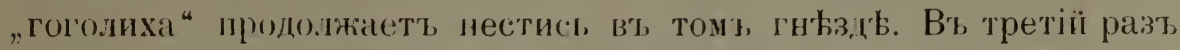
ее оставляютьь вт, покь. По соопценію мьстныхь жителей старка переносить пуховыхъ птенцовь на зем.ль или sне они сами рьшаится спрыгуть внизь, что имт, удается иногда и со зиачительной высоты. Случается, что иногда пьскольі гоголихъ несуть яйца въ одно и тоже гньздо. Находили вт одномъ гыьзды до 70 яиць. Если яйц: не будутъ удалены, начинаеть насиживать тольюо одна самка. Теплоты ея тъ.ла недостаточно. чтобы прогрћть всъ ряды яицт и только изь яиць верхняго слоя выходять птенцы. Относитель. но гнђздованія гоголя въ нарочно для нихь выставляемыхъ ящикахь си. Алфераки (стр. 189), гць со словъ H. Dresser’a указывается на Скандинавію и сњверную Финляндію, какъ на м'стности, гдь гоголя часто гныздятся въ подобныхъ яцикахъ.

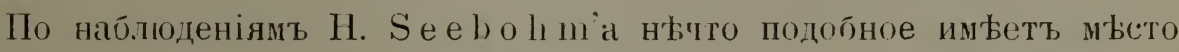
и на Енисеь (см. новое изданіе Науманна, стр. 164; оригиналь

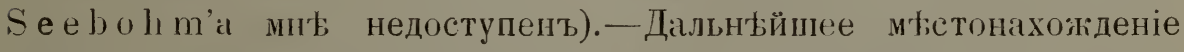
гоголя с. Ключевое. На Иртышы мы его не наблюдали, но по Плотникову (стр. ц(!) „встрбчается довольно часто. Очень осторовіенъ". По Морозову (стр. 3) гиъздящаяся птица.

Экземпляры коллекціи:

1) sех? pull. дер. Чистоозерская 24 rг 02 r. 23 a. - c. - t. 32 шк. 2) sex? pull. $\quad 26$ гі $0215-21$ жум.

Размьры и выст, скорлупы одного яица, взятаго П. А. Ша с-

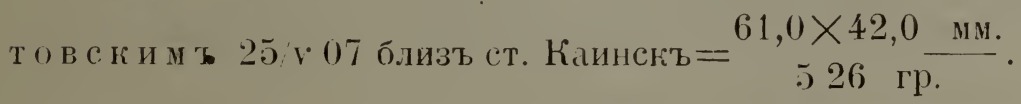

\section{¿sti. Harelda ghacialis Linn. Mopsнка.}

По А. Морозову (стр. 3) „только пролетомь“. Нами не наблюдался :тоть нырокъ въ степяхъ. но на пролеть встрычается по Об́и (Барнаулъ) и по Томи (Томски),

\section{巳s;. Oidemia fusca Linn. Typantı.}

Мъстн. назв.: „морской косачљ“ (станц. Каинскъ).

Турпанъ былъ найденъ П. А. ІІастов ским только на одномъ озерь (Шубино) близъ ст. Каинскт. Такь какъ мнь не 
приходилось видъть турпановь изъ степной части напего края, то остается пока невыясненнымъ вопросъ о поднгдь. Но въ Томскь быль убить экз. востотной формы Oidemia fusca stejnegeri Ridgw. (ср. мою замътку въ „Ornith. Jahł." 1904 стр. 93). А. Морозовт, (стр. 2) не наб̆людаль „чернявги-свирга“" и ссылается .лиш на указаніе И. Я. С.лов и о ва (стр. 160), по гіторому эта утка оыла добыта околи Омека 2-го ію.я 1874 г. 1 ревдко встрьчается даже во время перелетовь.

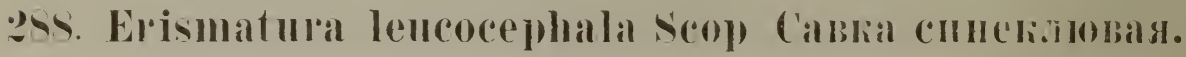

\section{Мьстн. наззв : „савочка“ (дер. Чистоозерская.)}

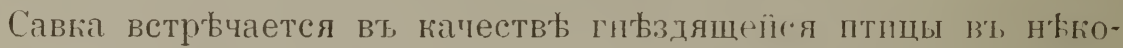
торнх и истахь степной части нашего края. Что касается Бара. бинской степи, то П. А. ШІ стовскому прихоцилос видыть этихъ утокъ на базарь станціш Каинскт, весною 1902 и 1903 г. O. Finsch (стр. 265) указываеть со ю.лов' Н. Я. Словцова на оз. Чаны, какъ на одно изъ убсть, гды́ особ́енно много савокъ. Во время Кулундинской пофздіи первыя савки бы.ли добы-

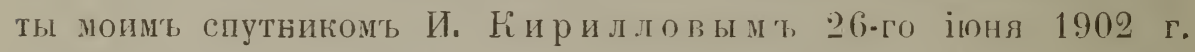
на озерь Поддорожномъ близъ дер. Чистоозерслой. На озерь было всего 11 савокъ, среди которыхъ замъчено 8 самцовъ. Моло дыхъ не было видно. Одну парочку удалось добыть, и тают, каћь въ нашемь музеь пока не было чучель этой утки, изъ обьих сдыланы чучела. Я самъ наблюдаль этихъ утокъ на томъ же озерь и на нбскольйхь другихь. Онь быль очень пуг.лив и осторожны, можетъ быть напуганы выстрьлами $k$ ири ил.т в а, такь что меня на выстрбль не подпускали и перелетали съ одного конца озера на другой. Плавають онь, погружая свое тъло г.тубоко въ воду, такъ тто надъ поверхностью воды видна толыіо небольшая частя спины въ вид' полосы. Ныряюпъ хорошо, но въ большинствь случаевъ цредпочитали удалиться летая чрезвы чайно низго надъ водою. При этомъ не задываютъ воду крыльями, какъ это на тьхъ озерахъ дълали Pod. auritus. Любимымъ мъстомъ пребыванія ихъ служатъ небольшія озера и притомъ не открытые плесы, а заливы ихъ, окруженные хоть частью камышами и тростниками. Савка водится и на озерахъ близт с. Клюлевого. Проьзжая 15-го іюля мимо озера Александровскаго (кирг. Чьянгс-куль), мы увидъли на немт ньеколько птукъ этихт краснвыхъ Утоют. 
Экземпляры колленіи:

1) б аd. д. Чистовзеркая $26 \times 02$ r. 45 a. 165 c. 108 t. 34 чуч.

2) ad. $"$ " $44,5 \quad 9431$ ?

На нахожденіе савки вт, Тонскомъ крағ указывают, уже слова Паллас а (стр 283) „in lacubus vastis camporum barabensium, ischimensum et isetensium frequens", такъ что Finsch напрасно дулаеть, что әта утка „bisher nicht aus Sibirien notirt" (стр. 265: ‘. А. Бутур.7и и (стр. 53) указываетъ почему-то лишь на Туркестанъ и гжныя части Тургайской и Акмолинской областей. B. ІІ В іанкш (етр. 19) на основаніи сборов'ь ПГ. Г. Иrнатова приводит, савку для Акмолинскаго и Атбасарекаго уьздовт; А Морозову о нахождепіи ея подт Омскомъ ничего неизвьстно, между тьми, какъ. И. Я. Словцовъ, (стран. 160) сообщаетт, что савња 17-го апрьля 1875 1'ода оыла убита подъ омскомт.

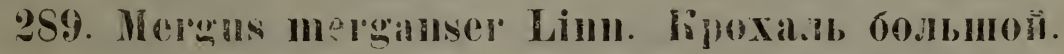

Свъдыній о нахожленіи большого крохаля в", степной части нашего края немного. Въ ғашихъ коллекціяхъ экземпляровъ нбтъ, но въ Кулундннкой степи на большиъ озерахъ, близъ деревни Чистоозерской и $\therefore$ Ключевого әтоть крохаль встрьчаетея (nid. ?) По М иддендорфу ( съ, длинноносыъ пролетаетъ близ'ь Барнаула, О нахожденіи большого крохаля близь, Барнаула и вообще на Оби между Барнауломъ и Томскомт, я нініп болье современныя евьдтнія отъ А. П Велижанина. Finsch (стр. 266) видбль экз. въ коллекціи Словц ова изт, окр. г. Омска, но здћ(ь атотьь крохаль согласно А. Морозову (стр. 2) не гнғздится. По свидътельству И. Я Словц口ва „большого крохаля льтомь не удавалюсь встрбчать въ Тюменскомъ, и Туринскомъ округахъ ..... Весной пролегаетъ большими партіями“. М. Д. Р узскій (стр. 24) приводитъ большого крохаля для пџьсныхь и солоноватыхт озеръ южной полосы Тобольской губерніи.

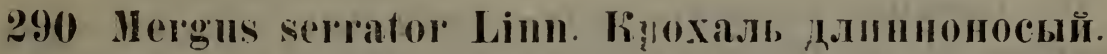

По сиобщенію казаковъ стан. Семиярской крохали встрбчаются пролетомъ на Иртышь. Осталось невыясненнымъ, пролетаетъ ли этотъ видъ, или предндущій, или и тоть и другой. $\mathrm{Bz}$ нашихт, голлекціяхъ этого вида также ньть. 
Что касается нашихъ степей, то уже Палласъ отмьчаеть (p. 287); in mediterraneis raro apparet, nisi in vastis lacubus Barabensium camporum “.... По И. Я. Словцову (стр. 232) „замъченъ на пролеть вмъсть съ предыдущимъ видомъ“. У одного только А. Морозова (стр. 2) имь̌ется прямое указаніе на то, что длинноносый крохаль приналлежить не только къ пролет. нымъ, но и гнђздующимъ птицамъ. На Оби по моимъ наблюденіямъ обыкновенная гнбздящаяся птица.

\section{Mergus albellus Linn. Лyrokł.}

Въ время пођздки по Кулундинской степи лутковъ наблюдали на озерь Поддорожномъ близъ дер. Чистоозерской, но экземпл. не был'ь добытъ. И. Я. Словцовъ (стр. 231) считаетэ, его гнбздящимся въ Тюменскомъ убъздъ. Равнымъ образсмъ и М. Д. Рузскій (стр. 24) приводитъ его въ перечнб видового состава фауны прђеныхт и солоноватыхъ озеръ южной полосы Тоб́льекой губ. А. Морозовъ (стр. 2) не имђетъ никакихъ доказательствъ относительно гнъздованія подъ Омскомъ лутка, точно также и В. Н. Плотниковъ (стр. 22), указывая на обильный пролеть ихъ весною и осенью, на основаніи сравнительно рБдко встрђчающихся лҺтомъ әкз. не можетъ утверждать, гнъздуютъ ли лутки.

\section{Прим Ъччаніе (къ стр. 20).}

Вельдетвіе весьма затянувшагося печатанія настоящей работы, сданной въ типографію еще въ сентябр⿱⿱亠䒑十凵 $1906 \mathrm{r}$, я имблъ возможность включить въ спеціальную часть ньксторые матеріалы, относяшіеся къ орнитофаунь нашихъ степей. не упомянутые въ ея общей части.

Это, главнымъ образомъ, часть оологическихъ сборовъ, произведенныхъ П. А. ШІастовски м въ 1907 г. вь Барабинской степи. 


\section{ЛИТЕРАТУРА.}

1) 1811 P. S Pallas Zoographia rossro-asiatica Petropoli.

2) 1842 E. Eversmann. Addenda ad cel Pallasii Zoographiam rosso-asiaticam. Casani

3) $1844 \%$ Fr Brandt. Remarques sur trois nouvelles espèces d'niseaux chanteurs appartenant aux genres Saxicola et Accentor. Bull. phys. math. T. 2 p. 139.

4) $1845 \mathrm{~F}$. Brandt Considérations sur les animaux vertébrés de la Sibérie occidentale p. 419 в'ь сочиненіи: Р. de Tciih a t $\mathrm{ch}$ eff. Voyage scientifique dans I'Altai oriental Paris.

5) I 48 (i. v. A elmersen. Reise nach dem Altai. Beiträge zur Kemntniss des russischen Reiches. Bd. 14.

6) 1855 A r. Midden dorff. Die Isipiptesen Russlands. St. Petersburg.

7) 1860 L v. Schrenck. Vögel des Amur-Landes. St. Petersburg

8) 1863 G. Rad de. Reisen im Süden von Ost-Sibirien. St. Peters burg.

9) 1866 Э. Эв ерсман н ъ. Естественная исторія Оренбургскаго края ч. Іи (Птицы). Казань.

10) 1870 С. Гуляевъ. „О фламингахъ въ алтайскомъ горномъ округь". (Здысь же замьтка о Pastor roseus). Томскія Губернскія Вьдомости № 15 стр. 8.

11) 1879 O. Finsch. Reise nach West-Sibirien im Jahre 1876. Wissenschaftliche Ergebnisse. Verhandlungen der zool. bot. Gesellschaft. Wien.

12) 1881 М. Богданов . Сорокопугы русской фауны и ихт сородичи. С. Петербургъ.

1:3) 1883 А. М. Никольскій. Путешествіе въ Алтайскія горы льтомъ 1882 г. Труды С.-Петерб. Общ. Естествоиспытателей. T. XIV. С.-Петербургъ. 
14) 1883 E. F. r. Hom e yer und C. A. 'Tancré. Beiträge zur Kenntniss der Ornithologie West-Sibiriens, namentlich der Altai-Gegend. Mittheilungen des Ornith. Vereines in Wien 1883.

15) 1 s88-1893. Dr. N. Sewertzo y et Dr. M. A. Menzbier. Ornithologie du Turkestan et des pays adjacents. Livraison I-jV.

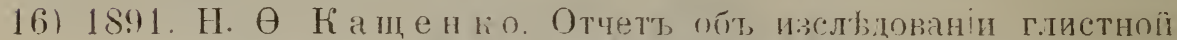
эпнзостіи рыбт, въ Барайинскихь озерахж. Томскъ.

17) 1891 Ө. Д. II е ске. Ornthographia rosica C-Петербургъ.

18) 1891 L. Taczanowski. Faune ornitholngique de la Sibérie orientale. St. Pétersbourg.

19) 1892 И. Я. Словцов Ђ. Позвоночныя Тюменскаго огруга и ихь распространеніе в’ь Тобольской губ Москва.

20) 1893 W. v. Rothschild und E. Hartert. Columba rupestris pallida subsp. nor.-- Ornith. Moniatsberichte I. P 41

21) 1895 H. Johansen. Ornithologische Beobachtungen in Tomsk. während des Jahres 1894-Ornith. Jahnl VI p. 183206.

22) 1895 М. А Мензбирт. Штищы Россіи. Москва.

23) $1896 \mathrm{H}$. Joh a nse n. Ornithologische Beobachtungen in Tomsk. Ornith. Jahrb VII 1. $125-146$

24) 1897 R. Biederman n. Die Federn in Magen der Podicipes-Arten -Oruith. Jahrb. VII p 6

25) $1897-1905$ Nauman n's Naturgeschichte der Vögel Deutschlands und des angrenzenden Mittel-Europas. Gera-Untermhaus

26) 1897 М. Рузскій. Краткій фаунистическій очеркъ южной полосьг Тобольской губерніи. Тобольскъ.

27) 1897 Н. Н. Сомовъ. Орнитологическая фауна Хәрьковскый губерніи. Харьковъ.

28) 1897 П. П. Сушкинъ. Птицы Уфимской губерніи. Москва

29) 1897 И. Я. Словц о т. Шутевыл заиски, веденныя во время пољздки въ Кокчетавскій уъздъ, Акмолинской области. въ 1878 г. Записки Зап Сй Отд. И. Р. Г. О. книяка XXI Омскъ*),

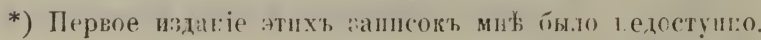


30) 1899 К. М. Дерю іинь. Путепествіе вь олину средняго и нижняго теченія рьки Оби и фауна этой области. Труды С.-Петербургекаго Общ. Естествоиспитателей T XXIX.

31) 1898 H. Johansen. Tetran tetrix tschusii subsp. nov. Vorläufige Mittheilung.-Ornith. Jahnb. IX. Heft 6. Beilage

- 32) 1 s98 Г. Э. І оганае нъ. О итицахт Томской губерніи. Изъ серіи публичныхт, пекцій, организованныхъ Томскимъ Отдбломъ Имг. Московскаго Общ. Сельск.Хоз. въ осеннемъ полугодіи 1897 г. Томскт.

33) $189 \mathrm{~s}$ А. Морозовъ. Списогъ птицъ Акмолинской области и прилегающих м встностей Тоболькой и Томской губ. Записки Зап. Сибирск. Отдьла Имп. Русскаго Географ. Общества. Книжка XXIV. Омскћ.

34) 1898 В. Н. Ллотниковт. Орнитологическіӥ очеркъ окрестностей поселка Ямышевскаго. ibidem.

35) 1899 H. Joh a nsen. Ornithologische Beobachtungen in Gouv. Tomsk während des Jahres 1898. - Ornith. Jahrlb. X. Heft. 4 .

36) 1899 Н. Ө Каш ен к. Результаты алтайской зоологической экспедипіи $1898 \mathrm{r}$. Позвоночныя. Томскъ.

37) 1900 - С. А

38) 1900 G. E. Hell mayr. Einige Bemerkungen ùber die Grau. meisen. - Ornitl. Jahrb. XI p. 201-217.

39) $1900 \mathrm{H}$. Johansen. Zur Fortpflanzung des Lanius excubitor homeyeri Cal..-Omith. Jahrb. XI p. $28--34$.

40) 1901 С. А. Бутурлин ъ. Синоптическія таблицы охотничьих' птицъ Россійской Имперіп. С.-ІІетербургъ.

41) 1901 С. А. Бутурлинъ. Дикіе гуси Россійской Ииперін. Tyila.

42) 1901 В. С. Елиатьевскій. Списокь Amphibia, Reptilia, Aves и Marmmalia, сооранныхъ въ 1898 г. въ Омскомъ убзздъ. Записки Зап. Сиб. Отц. Ими. Русск. Геогр. Общ. Книюика XXVIII. Москва.

4.3) 1901 E. Zi chy. Dritte asiatische Forschungsreise. Bd. II. Zoologische Ergebnisse. Budapest-Leipzig.

44) 1902 В. П. Аникинь. Отчетъ о командировкь въ Нарымскій край льтомъ 1900 г. Томскъ. 
45) 1902 V. Bianchi. Catalague of the known species of the Paridae or the family of tits. Ежегодникж Зоо.. Музея Имп. Акал. Наукъ. T. VII. С.-Петербургъ.

46) 1902 В. Біанки. Матеріалы для орнитофауны Акмолинской области. ibidem.

47) 1902 С. А. Бутурлинъ. Замьтки о нькотирыхъ птицахъ восточной Лифляндіи. Дневникь Зоол. Отдыл. Имп. Обш. Любителей Естествозн. Т. ШІ. № 3. Москва.

48) 1902 С. А. Бутурлинъ. Кулики Россійской Имперіи. Вып. I Тула.

49) 1902 H. Johansen. Ornithologisches von der sibirischen Eisenbahn. Ornith. Jahrb. XIII. p. 1-26.

50) 1902 H. Johansen Ornithologische Beobachtungen im Gouv. Tomsk während des Jahres 1899 (mit einer Tafel.). Orri thol. Jahrb. XIII. Heft 5-6.

51) $1902 \mathrm{H}$. Ober holser. A review of the larks of the genusOtocoris. Washington.

52) 1903 H. E. Dresser. A manual of palaearctic: hirds. Lominn.

э3) 1903 - E. Hartert. Die Vögel der paläarktischen Fauma. Berlin. 3 Lieferungen

54) 1903 H. Johansen. Über das Vorkommen des braunkehligen Wiesenschmätzers in Sibirien und seine sibirische Form Pratincola rubetra margaretae Johansen sulspp. nova. Ornith. Jahrh. XIV. Heft. 5, $\mathbf{6}$.

5.) 1903 V. v. Tschusi. Über palaearktische Fomen. V. Ornithol. Jahrb. XIV. p. $161-170$

56) 1904 С. Н. А.лфераки. Гуси Россіг. Москва.

57) 1904 В. Біанки. Предварительная замытка о восточно-палеарктическихъ формах'ь рода Alauda Limn.-Eжегодникъ Зоол. Музея Имп. Акац. Наукъ. Т. IX стр. XXII. С.-П.

58) 1904 H. Johansen. Vollständiger Albino von Hypolais salicaria Pall.-Ornith. Monatsberichte. Juniheft.

59) 1904 If. Johansen. Wichtigere Ergebnisse während der Jahre 1900-1903 im Gouv. Tomsk ausgeführter ornithologischer Beobachtungen.-Ornith. Jahrb. XV. p. 81--93.

60) 1.904 H. Johan sen. Wovon nährt sich der Würgfalk (Falco sacer Gmel.)?. Ornith. Monatsschrift XXIX № 7.

61) 1904 H. Johansen. Vorläufiger Bericht über einè im Sommer 1902 in die Kulundinsche Steppe und die angren- 
zenden Teile des Ssemipalatinsker Gebietes unternommene Reise. -Ornith. Jahrb. XV. Heft. 5, 6.

62) 1904 Th. L, or e $n$ z. Lagopus albus (L.) nov. subsp. major. Ornith. Monatsberichte XI p. 177.

63) 1904 V. v. Ts chus i. Über palaearktische Formen. VI. Über Alcedo ispido L. und ihre Formen. - Ornith. Jahrb. XV $93-108$.

64) 1904 V. v. Tschusi. Über palaearktische Formen VU. Ornith. Jahrb. XV. p. 227.

65) 1906 N. Sa rudny und H. Bar on Loudon. Asio accipitrinus pallidus subsp. nov. Ornith. Monatsberichte XIV p. 151.

66) 1906. С. А. Бут урлин ъ. Күлики Россійской Имперіи вып. II. Москва.

67) 1907 S. A. Buturlin Stryx doliata Pall. Ornith Monatsberichte. XV. № 6 .

68) $1907 \mathrm{~S}$. A. Buturlin. Palaearktische Formen von Picoides. Lacép. Ornith. Monatsberichte XV. p. 9.

69) 1907 С. А. Бутур и инъ. Замћтки о группахъ бълоспинныхъ дятловъ и каменныхъ поползней. Изв Кавказск. Музея т. Ш вып. I Тифлисъ. 


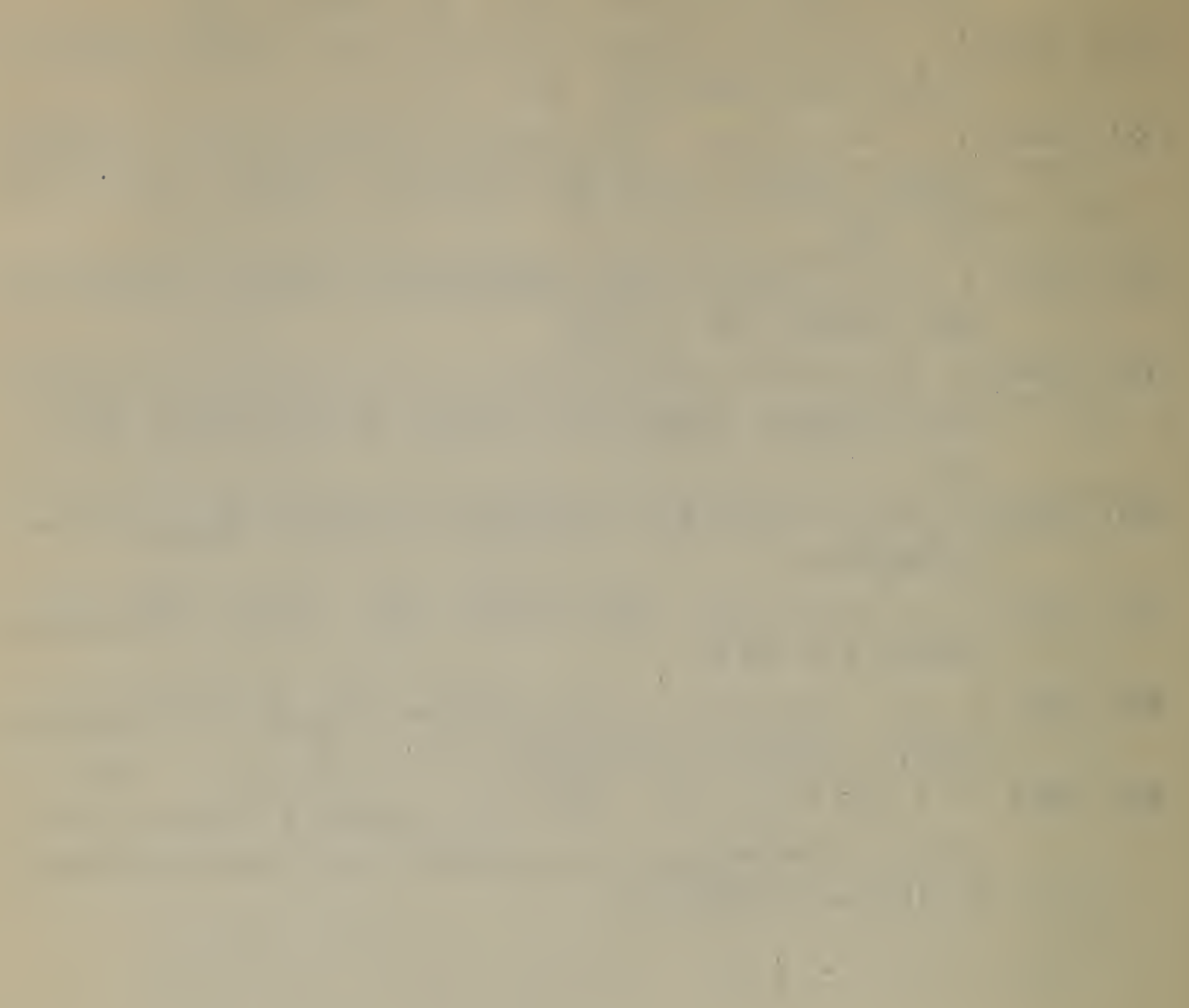




\section{CORRIGEN DA}

Напечатяио:

(тр. строчка

\begin{tabular}{|c|c|c|c|}
\hline 5 & 3 & сверху & lencocephalos \\
\hline 11 & 3 & $"$ & fascipilea \\
\hline 12 & 6 & снизу & citrcola \\
\hline 20 & 4 & сверху & lencocephalos \\
\hline 29 & 3 & $"$ & agric lus \\
\hline 22 & 7 & снизу & Lauius phoenicuroides \\
\hline 23 & 14 & сверху & flammea flammea \\
\hline 26 & 15 & $"$ & 286 \\
\hline 26 & 18 & снизу & Nycticor $\mathrm{x}$ \\
\hline 27 & 2 & сверху & 113 \\
\hline 27 & 21 & $n$ & Pavon ella \\
\hline 28 & 5 & $n$ & n veus \\
\hline 28 & 21 & $"$ & cr status \\
\hline $2 \mathrm{~s}$ & 20 & снизу & Varrel \\
\hline 28 & 18 & ? & abbifrons \\
\hline 30 & 4 & сверху & нашгнхъ \\
\hline 35 & 2 & , & бмизт. \\
\hline 36 & 9 & снизу & он'ъ \\
\hline 42 & 1 & $"$ & nac \\
\hline 45 & 11 & сверху & подтвердять \\
\hline 49 & 1 & снизу & 'оий \\
\hline 71 & 3 & сверху & Kundoo \\
\hline $7 !$ & 16 & сниз̣у & Сорочка \\
\hline 82 & 14 & $"$ & flammea flammea \\
\hline 101 & 10 & $n$ & стени \\
\hline 107 & 15 & сверху & путешестиія \\
\hline 110 & 12 & $\eta$ & паселяющему \\
\hline 129 & 18 & $"$ & macrurns \\
\hline 136 & 2 & $"$ & орель-змеяды \\
\hline 142 & 10 & $n$ & дербикь \\
\hline 163 & 17 & снизу & около \\
\hline 186 & 3 & r. & шодверанденія \\
\hline 217 & 4 & $"$ & Семипатинска \\
\hline 221 & 16 & $n$ & паходит"ь \\
\hline 237 & 1 & сверху & олину \\
\hline
\end{tabular}

Сльдуетьь читать:

leucocephalos

fuscipilea

citreola

lencocephalos

agricolus

Lanius phoenicuroides

linaria linaria

186

Nycticorax

213

Paroncella

niveus

cristatus

Yarrel

albifrons

กเดแบхะ

близ'ь

она

nach

подтвердит'

этой

kundoo

сорочка

linaria linaria

стеши

путешествія Ledehour'a

населяющему

macrurus

орель-змтендъ

дербник"

чаще около

шодтвержденія

Семипалатинска

находит,

долину 

$=0$ $=$

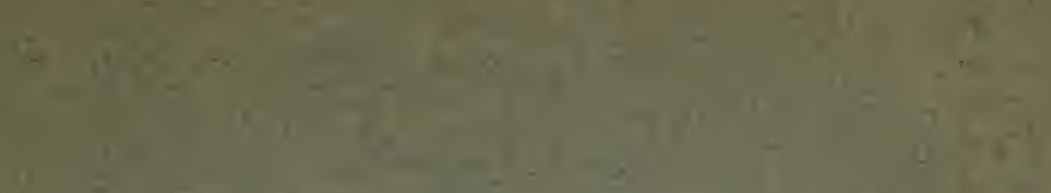

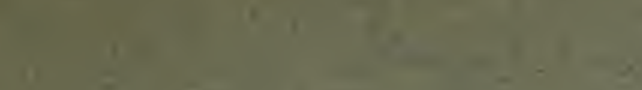

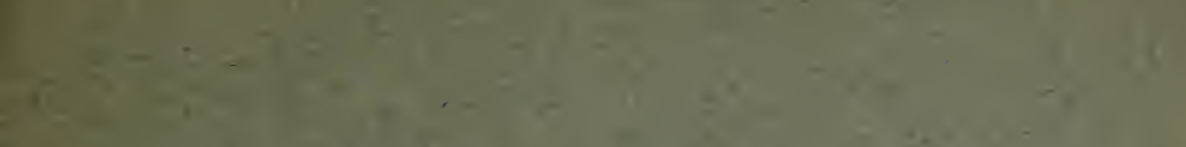

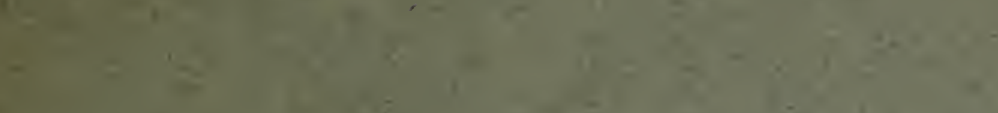

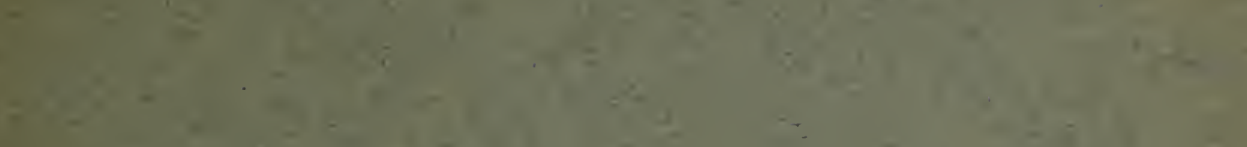

5

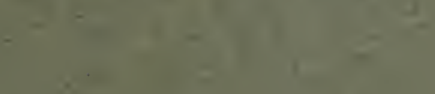$$
\because+10+10
$$

5

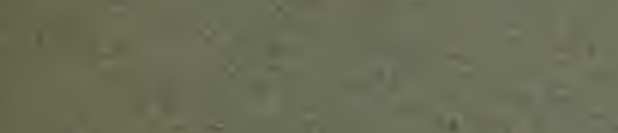

(1)

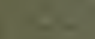
1

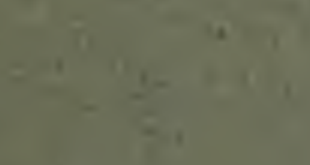

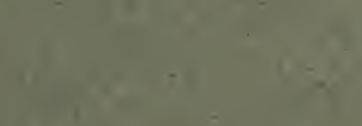

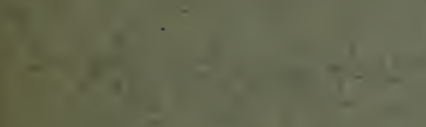

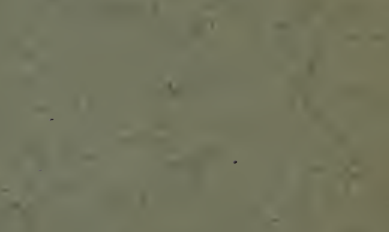
12

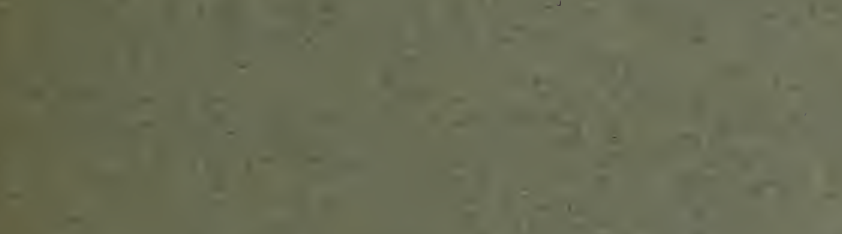

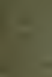

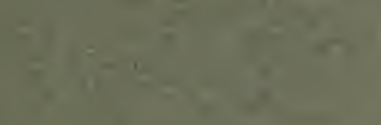

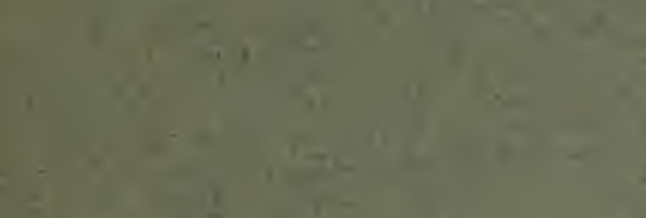

$-$

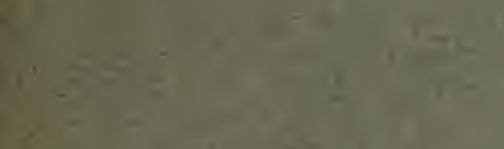

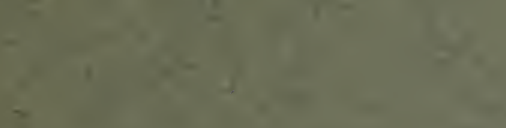

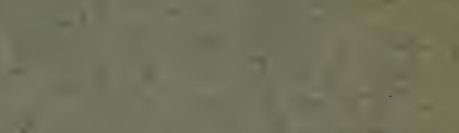

$-1=1$

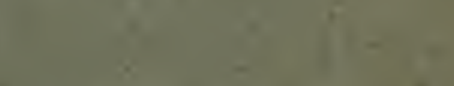

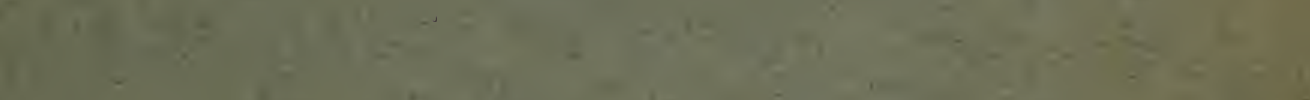

c. 


\section{s.

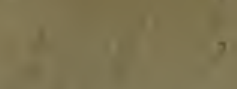

$2, \frac{1}{1}$

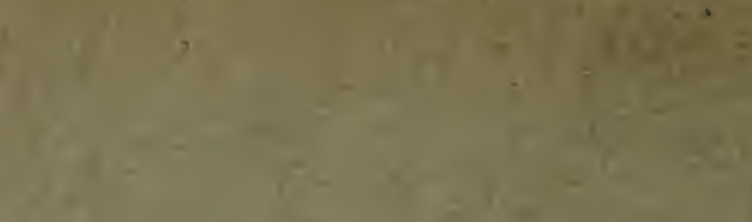

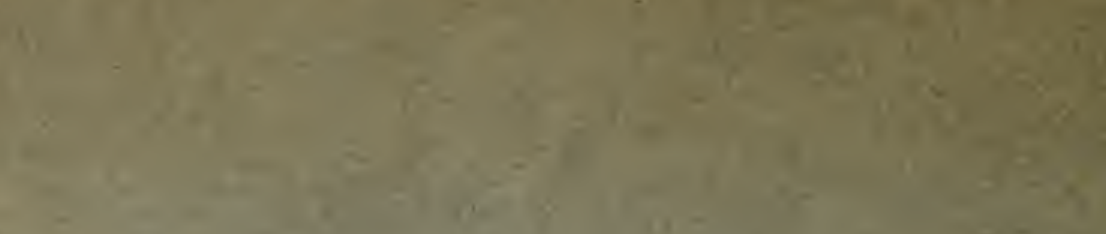

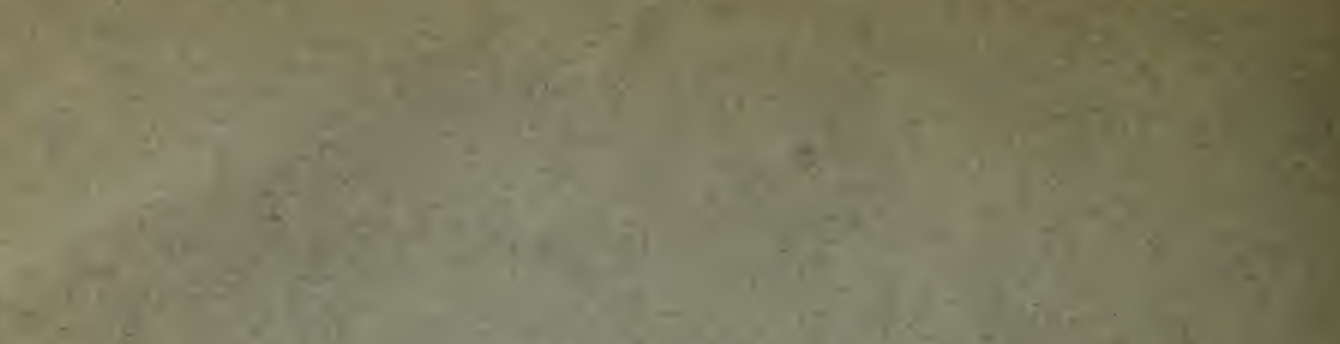

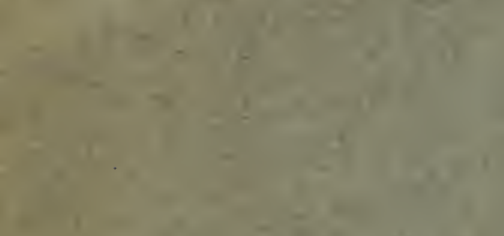

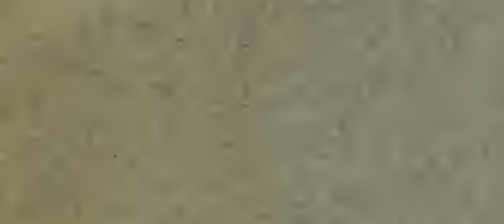

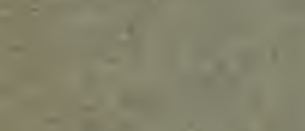

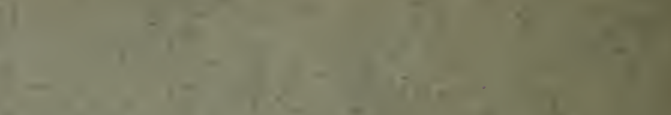

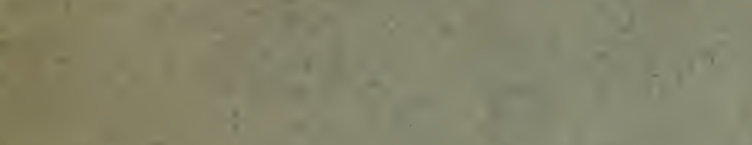

$18 x^{2}-3$

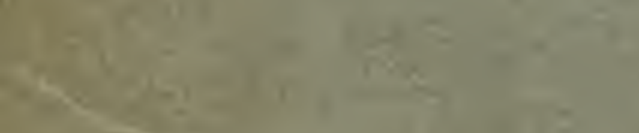

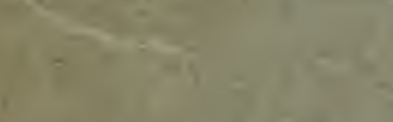

s.

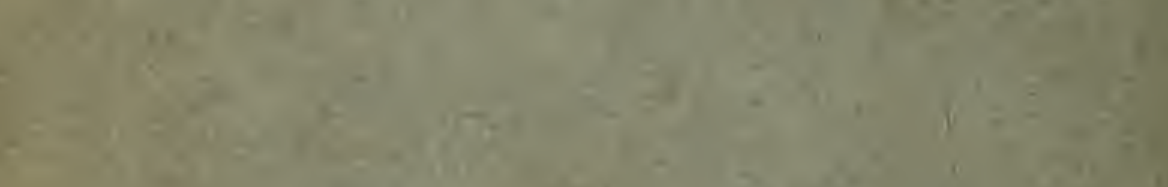

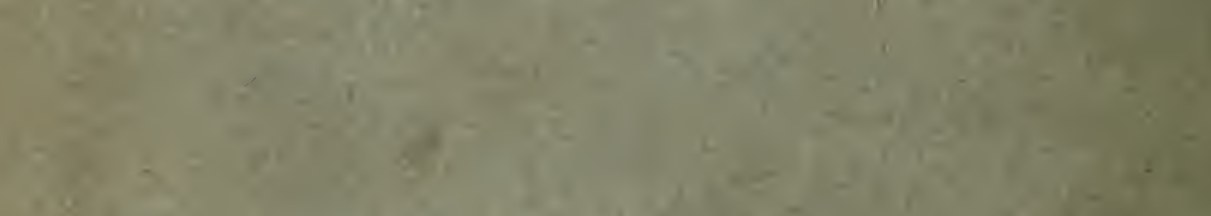

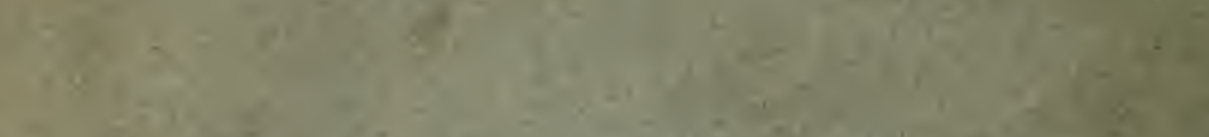

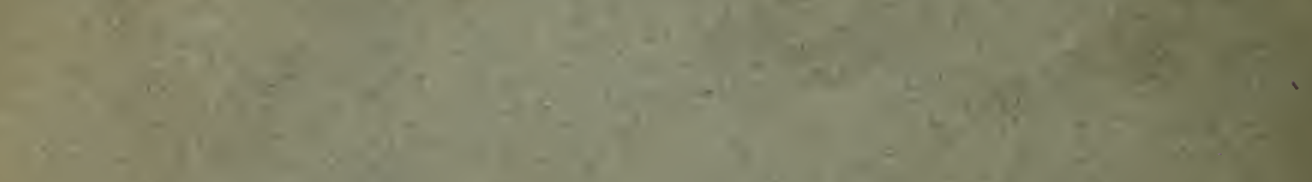

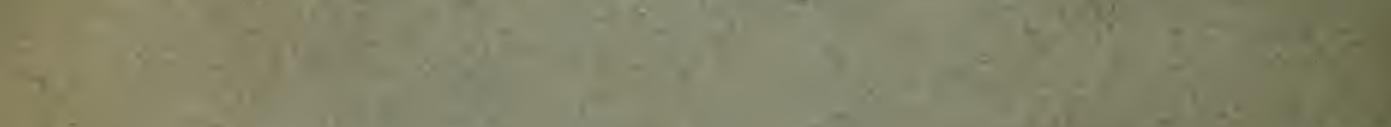

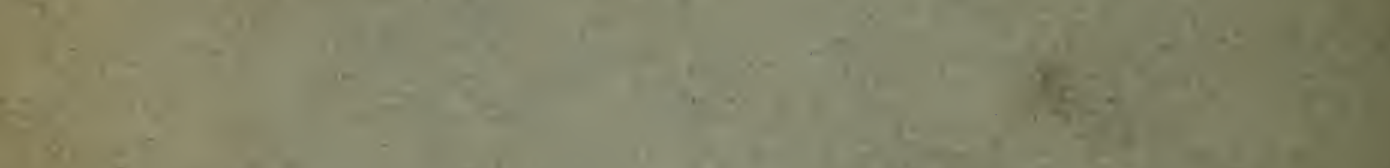

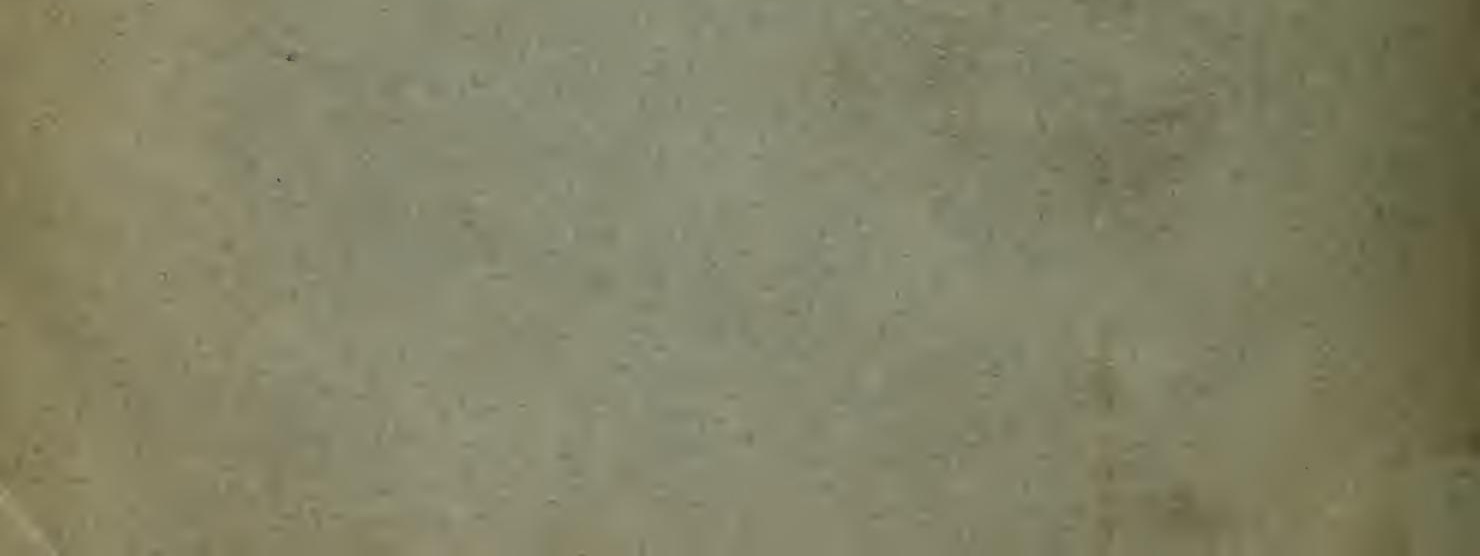






\section{$32044 \quad 107222143$}

\section{Date Due}

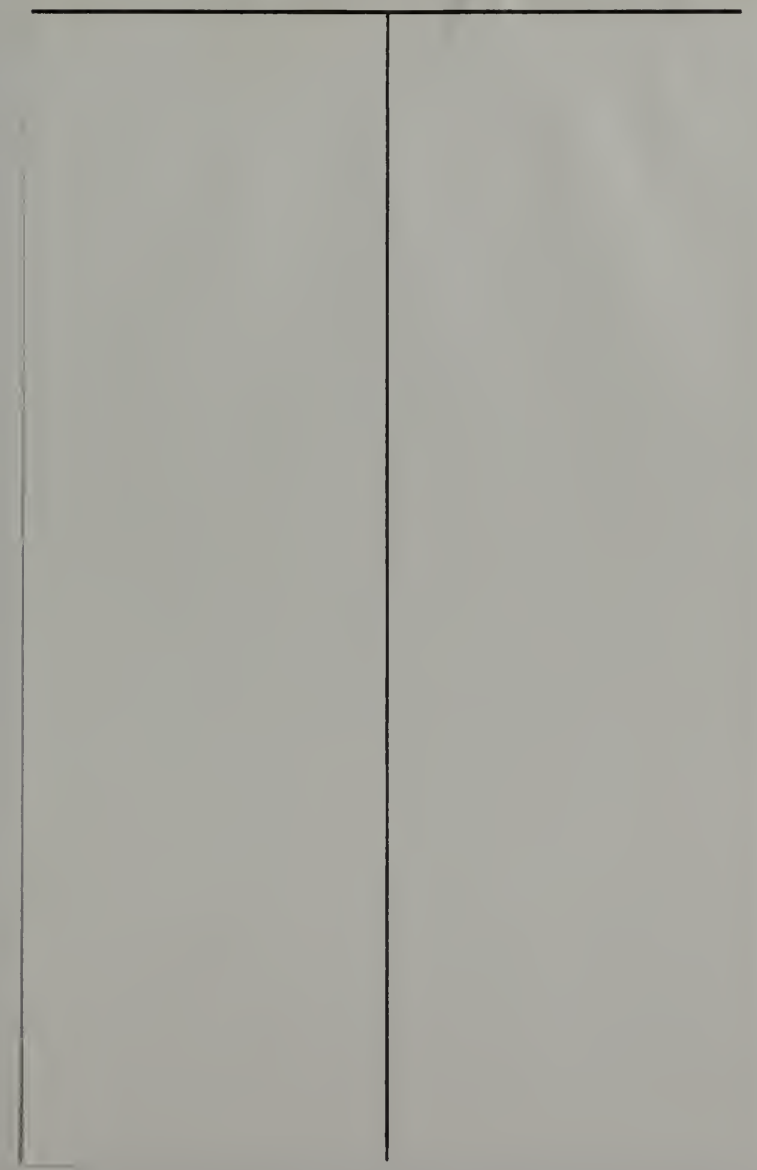


as

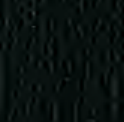

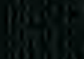

